\title{
Unbuilding cities : obduracy in urban sociotechnical change
}

Citation for published version (APA):

Hommels, A. M. (2001). Unbuilding cities : obduracy in urban sociotechnical change. [Doctoral Thesis, Maastricht University]. Universiteit Maastricht. https://doi.org/10.26481/dis.20010920ah

Document status and date:

Published: 01/01/2001

DOI:

10.26481/dis.20010920ah

Document Version:

Publisher's PDF, also known as Version of record

\section{Please check the document version of this publication:}

- A submitted manuscript is the version of the article upon submission and before peer-review. There can be important differences between the submitted version and the official published version of record.

People interested in the research are advised to contact the author for the final version of the publication, or visit the DOI to the publisher's website.

- The final author version and the galley proof are versions of the publication after peer review.

- The final published version features the final layout of the paper including the volume, issue and page numbers.

Link to publication

\footnotetext{
General rights rights.

- You may freely distribute the URL identifying the publication in the public portal. please follow below link for the End User Agreement:

www.umlib.nl/taverne-license

Take down policy

If you believe that this document breaches copyright please contact us at:

repository@maastrichtuniversity.nl

providing details and we will investigate your claim.
}

Copyright and moral rights for the publications made accessible in the public portal are retained by the authors and/or other copyright owners and it is a condition of accessing publications that users recognise and abide by the legal requirements associated with these

- Users may download and print one copy of any publication from the public portal for the purpose of private study or research.

- You may not further distribute the material or use it for any profit-making activity or commercial gain

If the publication is distributed under the terms of Article $25 \mathrm{fa}$ of the Dutch Copyright Act, indicated by the "Taverne" license above, 


\title{
Unbuilding Cities
}

\section{Obduracy in Urban Sociotechnical Change}

\author{
PROEFSCHRIFT
}

ter verkrijging van de gralad van doctor aan de Universiteit Maastricht.

op gezag van de Rector Magnificus, Prof. dr. A.C. Nieuwenhuijzen Kruseman volgens het besluit van het College van Decanen,

in het openbaar te verdedigen op

donderdag 20 september 2001 om 16.00 uur

door

Anique Marie Hommels

geboren op 3 december 1972

te Bunde 


\section{Promotor:}

Prof. dr. ir. W.E. Bijker

\section{Co-promotor:}

Dr. K. T. Bijsterveld

\section{Beoordelingscommissie:}

Prof. dr. R. de Wilde, voorzitter

Prof. ir. D.H. Frieling (Technische Universiteit Delft)

Prof. dr. M.C. Kuipers

Prot. dr. H.C.G. Spoormans

Dr. S. Wyatt (Universiteit van Amsterdam) 


\section{Unbuilding Cities}


(C) Anique Hommels, 2001

ISBN 90-9014963-5

Cover design: kjoep

Printed by: Datawyse / Universitaire Pers Maastricht

The production of this thesis has been sponsored by:

Graduate School Science, Technology \& Modern Culture (WTMC)

Department of Technology \& Society Studies

Faculty of Arts and Culture

J.A. Jurriaanse Stichting 


\section{Table of Contents}

Acknowledgements

Chapter 1 - Introduction: Technology and the City

Unbuilding cities

11

Obduracy of technology

18

Technology and the city

20

Chapter 2 - Obduracy of Sociotechnology:

Four Theoretical Conceptions

Material obduracy

27

Dominant ways of thinking $\quad 30$

$\begin{array}{ll}\text { Embeddedness } & 34\end{array}$

Persistent traditions $\quad 38$

Comparison of the four conceptions of obduracy 44

The analysis of obduracy in processes of urban sociotechnical change 47

Chapter 3 - Obduracy and Dominant Ways of Thinking:

Changing Utrecht's Down Town Shopping Area (Hoog Catharijne) 51

Introduction 51

Cast in concrete: Plan Hoog Catharijne $\quad 54$

Building up technological frames $\quad 58$

Two types of obduracy $\quad 62$

Overcoming obduracy 71

Obduracy and dominant ways of thinking $\quad 75$

Chapter 4 - Obduracy and Embeddedness:

Trying to Reconstruct the Highway That Cuts Through Maastricht $\quad 77$

Introduction $\quad 77$

Designing and building Highway 75 (1956-1960) 78

Reconstructing the intersections (1974-1978) 85

Trajectory Study (1978-1982) 89

Temporary measures (1982-1993) 96

Trajectory/EIS Study (1994-1998) 99

$\begin{array}{ll}\text { Obduracy and embeddedness } & 108\end{array}$ 
Chapter 5 - Obduracy and Persistent Traditions:

The Spatial Renewal of the Bijlmermeer

Introduction

113

Establishing a tradition

114

Persistence of tradition: Maintaining and improving the established town

planning structure (1974-1986)

122

Contested tradition - Disputed neighborhood (1986-1992) $\quad 126$

Intervening in the established town planning structure: Abandoning or 135

preserving a tradition? (1992-1998)

Obduracy and persistent traditions

\section{Chapter 6 - Conclusions:}

Obduracy in Urban Sociotechnical Change

Introduction

Understanding obduracy

Unbuilding strategies

Strategies to preserve obduracy

Obduracy ats construction and reality

STS and the city

Epilogue

Notes

Bibliography

201

Interviews

201

Archives

203

References

Samenvatting (summary in Dutch) 


\section{Acknowledgements}

My interest in research of sociotechnical change came up during my undergraduate studies at the Faculty of Arts and Culture in Maastricht. In 1991, I started this in the Netherlands completely new and unique studies. I was intrigued by its 'interdisciplinary' approach - combining philosophy, history, sociology and arts. To my own surprise - I considered myself to be a genuine 'alpha' having spent most of my secondary education on learning languages - I chose the specialization in 'Technological Culture'. In the final stages of my specialization I became a student assistant in a research project with Wiebe Bijker and Jessica Mesman. During this project I got a glimpse of what it meant to do research of technology and society, and I liked it. I was happy when I obtained a position as a PhD student at the Department of Technology and Society Studies with Wiebe Bijker as my supervisor. Later on, Karin Bijsterveld became my second supervisor.

For me, Wiebe and Karin together formed an excellent team of supervisors. They shared an inspiring enthusiasm for research in Science, Technology and Society studies (STS) and a sharp vision and consensus about where my $\mathrm{PhD}$ project was heading for. Wiebe succeeded very well in finding a delicate balance between steering my research and giving me the idea that I had a lot of freedom in pursuing my own interests. His optimism, support and confidence helped me to continue my work and to remain enthusiastic till the end. Karin was a very critical, precise and sharp reader of my drafts. Her comments were always very helpful and to the point. The numerous conversations I had with them about what later became this book, were always very enjoyable and motivating.

I greatly appreciated the ways in which my colleagues at the Faculty of Arts and Culture showed their interest in my project. I thank all those colleagues who, in the early stages of my research, regularly put interesting articles, books, references, or invitations for seminars and lectures in my pigeon hole. I am particularly grateful to the members of the BOTS research group for their willingness to read draft chapters and to provide detailed comments in a fine, supportive atmosphere. The suggestions of Roland Bal, Ernst Homburg, Marieke Kuipers, Ruth Mourik, Bernike Pasveer, Peter Peters, Geert Somsen, Jo Wachelder, and Ger Wackers during the annual BOTS "summer harvests" and on other occasions have been of great significance for the sharpening of my arguments. I am also indebted to Paul ten Have of the University of Amsterdam for his comments on an early draft of the Bijlmermeer chapter, and to Bernard Leupen (TU Delft) for his useful remarks about various chapters in this book. I am also grateful to the secretaries of our Department, Sabine Kuipers, Joke Oud and Elleen Schelling, who were always very kind and helpful.

The group of $\mathrm{PhD}$ students at the faculty has been extremely supportive during my whole project. At the beginning I shared my premature ideas for research with the 
'french fries" group. Later on this group became strengthened by newly appointed $\mathrm{PhD}$ students in the 'pizzalsoup' group. We discussed draft chapters and research problems and pitfals. During the weekly lunches in Café de Poort we talked about the latest faculty gossip and the progress we made in our own research. Although our $\mathrm{PhD}$ projects differed very much in terms of topies, there appeared to be enough common ground to understand and help each other. The meetings and discussions with this group helped me very much and I want to thank the participants: Cecile Aandestegge. Ruth Benschop, Mareo Goud. David Hamers, Ruud Hendriks. Stine Jensen, Eric Lemmens. Jessica Mesman, Ruth Mourik. Peter Peters, and Jessica Slijkhuis.

David was a great roommate during the past few years. We were both interested in cities and suburban districts, although we preferred to study them in quite different ways. It was nice to share the daily ups and downs of doing research and undergraduate teaching with him. Every now and then Peter Peters knocked on the door of our room and entered to chat or for some more serious talking. On such occasions we had nice discussions about doing (contract) research and about our PhD projects. Peter's great knowledge of Dutch national mobility policy helped to improve Chapter 4 considerably. Despite Peter's critical attitude towards increasing mobility and his preference for slow modes of transportation, I never spent more time in airplanes, high speed trains and cars than during the one-year PROTEE project in which Peter. Wiebe and I worked together.

Several workshops and conferences in the Netherlands and abroad formed useful experiences. The most memorable workshop I visited was the "Technological Futures-Urban Futures" workshop in Durham in 1998. This workshop was aimed at bringing together scholars from urban studies, STS and large technical systems approaches. I should also mention the workshops and summerschools organized by the Netherlands Graduate School of Science, Technology and Modern Culture (WTMC) which provided an intensive PhD training. I found the annual Winterschools in which (senior) $\mathrm{PhD}$ students received comments on draft chapters from other $\mathrm{PhD}$ students and (inter)national STS scholars the most useful and rewarding events.

This book could not have been written without the help of many interviewees. I was surprised that most of the people I contacted were willing to be interviewed. Many of these conversations turned out to be very interesting and useful for my research. I thank the interviewees for granting me the interviews. Many of them were so kind to provide comments on draft versions of my chapters. For this. I want to thank Ed Bolt. Armand Cremers, Dirk Frieling, Lucas van Herwaarden, Susan van der Hilst, Carla Konsten, Bart Lambooy, and Jacques Peters.

In the final stages of my project. Ton Brouwers carefully edited my English with great precision and craftmanship. In fact he did much more than correcting it he improved the rhetorical style of my thesis and he made very useful suggestions for improving the argumentation.

I met Barbara Allart. Esther van 't Klooster and Thessa van Hoorn during our undergraduate studies in Maastricht and we became friends. After they moved out of Maastricht, the walking, cycling and museum trips we made in or near Utrecht, Rotterdam. and Maastricht provided much needed distraction. I thank them and my other friends and family who showed their interest on various occasions during the past five years. 
I am happy that my parents, Harry and Margot Hommels. and my brothers Joep en Michiel took sincere interest in my work. Harry and Margot even read parts of the book in its final stages and Joep did a great job in making its cover design. Their unconditonal support and confidence hats always been of great importance for me.

Ever since we became friends at secondary school, Reinout Hesselink accompanied and supported me in many of my activities with his good sense of humour and his ability to put things in perspective. Although Reinout certainly contributed much to this book by reading and commenting parts of it and because of his patience in listening to my efforts to clarify some of my brand new ideas, he also reminded me of the other pleasures of life. I enjoyed our numerous trekkings with tent and rucksack through sparsely populated, often rainy areas of Scandinavia, Iceland, Scotland. Ireland and Nepal, and these certainly improved our endurance. I thank Reinout for our great times together.

Anique Hommels

Maaastricht, May 2001 


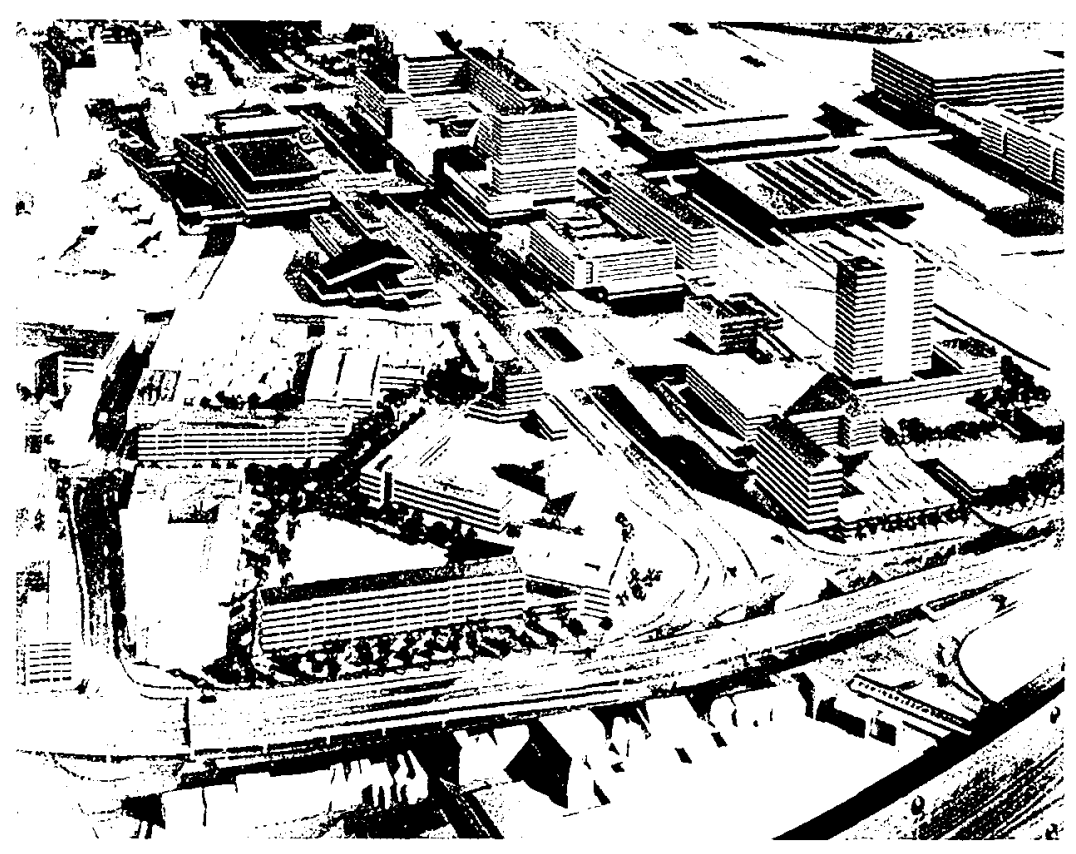

Figure 1.1: Spatial model Hoog Catharijne (1968)

Source: Het Utrechts Archief

Figures 1.1 and 1.2 depict roughly the same areat but have a different North/South-orientation.

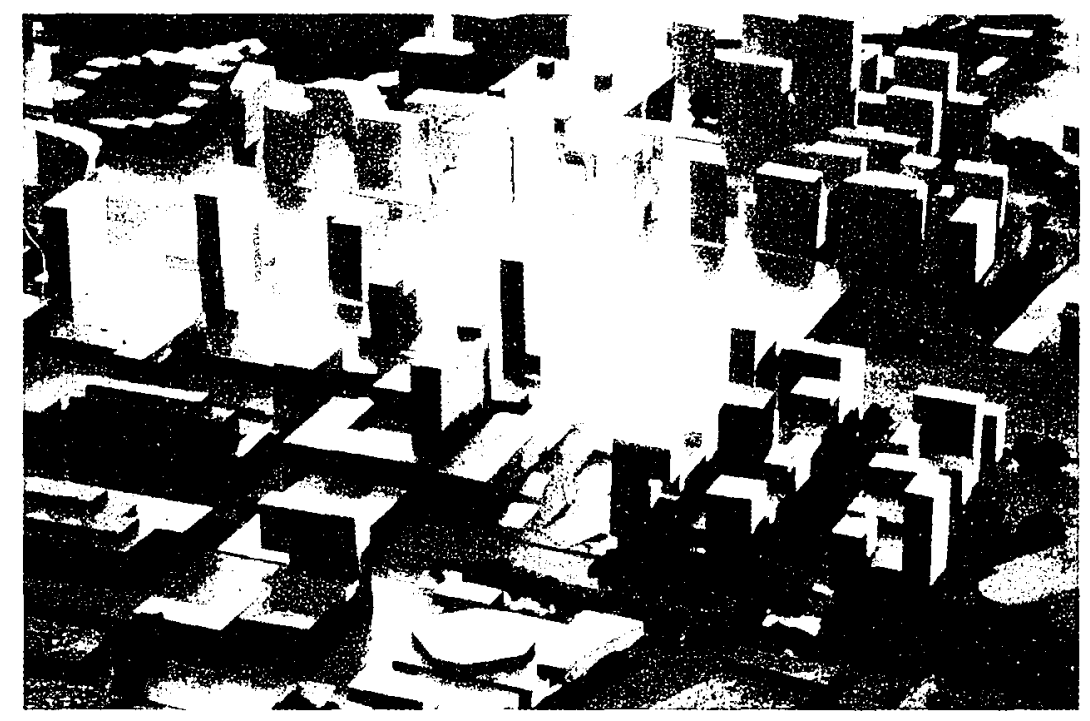

Figure 1.2: Spatial model Definitive 'Town Planning Design UCP (1998)

Source: Projectbureau UCP Utrecht 


\section{Introduction: Technology and the City}

\section{Unbuilding' cities}

- Utrecht. December 1997. The city council of Utrecht agrees with plans to demolish one quarter of a generally despised but commercially successful shopping mall right in the middle of the city's downtown area: Hoog Catharijne. It took ten ycars of debate and controversy to reach this decision. The indoor mall was planned and built in the 1960s as part of a large-scale redesign of Utrecht's city center. the socalled Plan Hoog Catharijne. It not only comprised a mall, but also a new railway station, a bus station, new infrastructure, offices, cultural facilities, and apartment buildings-all integrated and interconnected. Twenty years later, in the mid-1980s. the negative effects of Plan Hoog Catharijne became more and more apparent, which ultimately caused the city to initiate a new project aimed at upgrading the area: the Utrecht City Project (UCP). Despite Hoog Catharijne's commercial success. its overall concept began to be generally perceived as outdated, its architecture as outright ugly; the drug addicts and homeless people who populated the indoor mall in ever-larger numbers further damaged its image. For quite some time, though. it seemed highly unlikely that Hoog Catharijne would ever be touched in the slightest way: in all its unsightliness it had become accepted as a fact of life. If. however, the Utrecht city council follows up on its decision of December 1997, Hoog Catharijne's partial demolition will nevertheless become a reality in the near future.

- Madstricht, October 1998. The Dutch Minister of Transportation decides to postpone all planning activities for a major highway reconstruction project in Maastricht until after 2012. The two-kilometres highway stretch involved basically divides the city in two and is the last part of the Dutch highway system that cuts through a densely populated urban area without overpasses." Due to the extraordinary growth of the number of cars since the 1960s, local congestion has increased substantially, especially during peak hours. At the same time. Maastricht's overall accessibility and livability, as well as the safety of its traffic, have seriously diminished. This particular highway trajectory is seen as the last bottleneck of the amoroute du soleil, running from Amsterdam, the Netherlands. to Genova. Italy. 


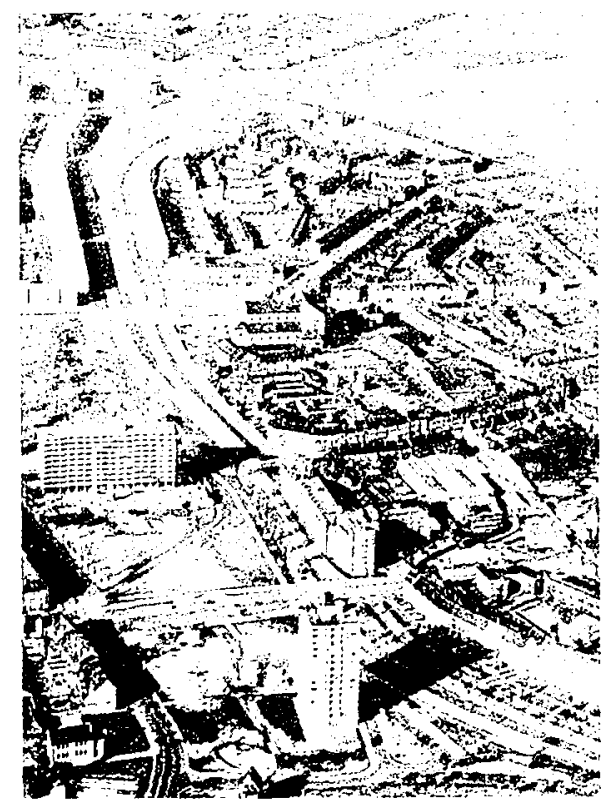

Figure 1.3: The highway that cuts through Maastricht (1968)

Source: Gencentearchicf Matastricht (1) Gemeentearchief Malastricht Picture taken by J. Naseman

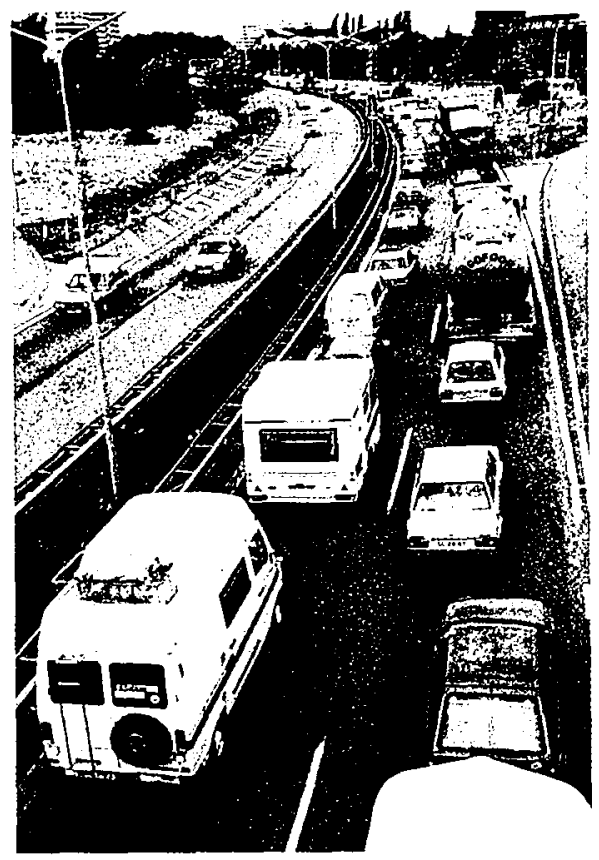

Figure 1.4: Congestion at the highway that cuts through Maastricht (approx. 1985)

Source: Gemeentearchief Malastricht 10 Fotopersburealu P. Mellaart 
Since the highway's construction in the early 1960s, engineers, politicians, and citizens have constantly vied to change and adapt it. One of the major redesign proposals, building a tunnel, has been considered from the very beginning, but so fat no solution has been implemented. Despite all efforts at altering the highway's design, thus improving the local situation and allowing through traffic to avoid the city. the existing inf rastructure maintained its obduracy.

- Amsterdam. July 1999. During a visit to the Bijlmermeer, one of Amsterdam's suburban districts. I witness the demolition of a huge multi-level parking garage and a shopping center. Since 1992, a number of apartment buikdings have already been torn down in this part of the city. According to the present plans only ten of the original thirty apartment complexes will survive. The Bijlmermeer was built in the 1960s and 1970s according to a functionalist design, its high-rises and spacious apartments originally intended for Dutch middle class families. Quite soon. however, it became cleal that these middle class families were hardly attracted to the Bijlmermeer's outlay and rapidly it grew into a refuge for minorities, refugees and immigrants, who began to enter the country in larger numbers. Plagued by unemployment and high crime rates, the Bijlmermeer had become one of the most criticized urban districts of the Netherlands by the 1980s. At first, however. changes in its basic design were not seriously considered at all. Only after years of discussion, in which the city of Amsterdam, the neighborhood council, housing corporations, community workers and residents took part, it was eventually decided in 1992 that a rigorous spatial renewal of the Bijlmermeer would be inevitable in order to solve its urgent social problems and the severe financial problems of the housing corporation. This new town plan meant a radical break with the original concept, as over the years many of the huge apartment buildings are to be replaced by singlefamily homes. Meanwhile, a small number of Bijlmermeer residents try to preserve part of their living environment by establishing a "Bijlmer Museum" that aims at conserving and displaying the designs and modernist principles on which the original urban plan was based.

These three stories illustrate the central theme of this book: it is about the confrontation between ongoing attempts to change cities. even involving the most recent additions or innovations, and the obduracy of the overall urban layout. This study deals with the clash between a variety of new ideas about urban development and the multifarious viewpoints that are already embedded in a city's existing urban structures and outlook. This investigation addresses the unexpected or unforeseen societal developments that gradually give rise to a questioning of existing urban configurations. It is about urban design and challenges to renew it, a process in which commonly the stakes are thus high that years of planning, debate, and controversy may result in no changes at all in some cases, while in others it may eventually result in concrete and lasting urban reconfiguration. 


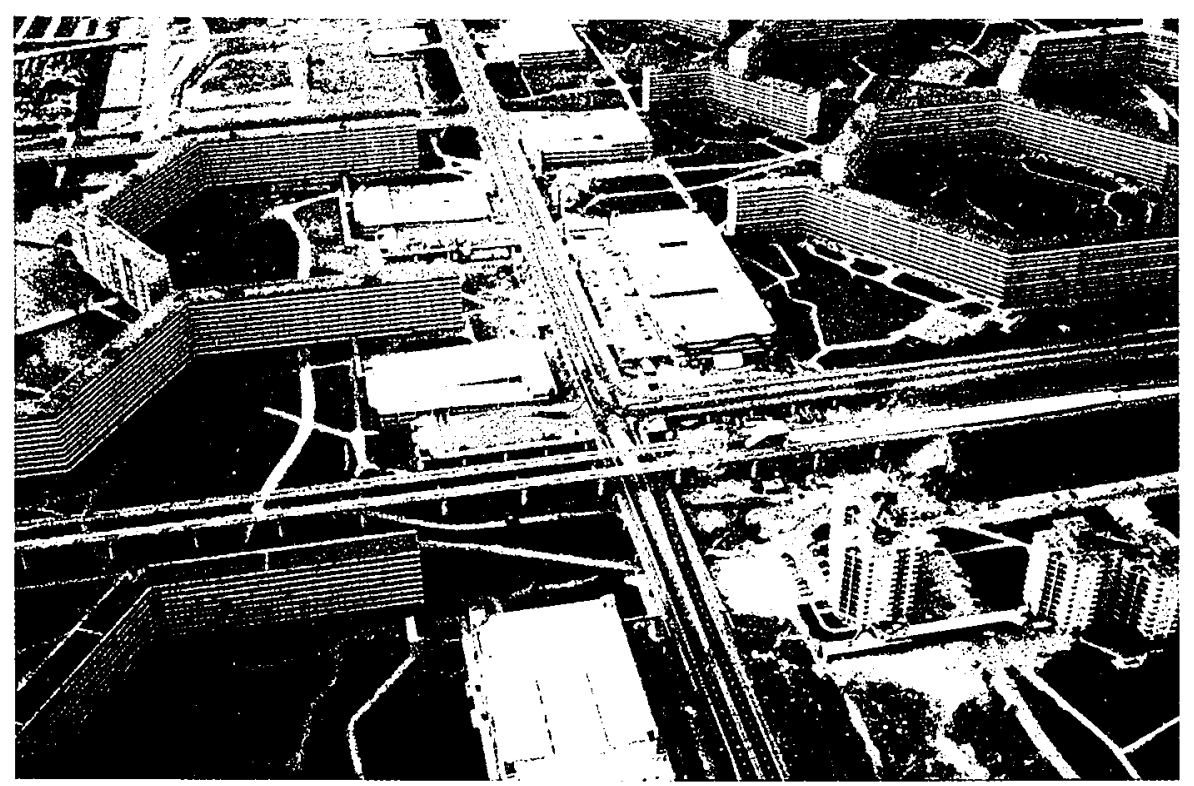

Figure 1.5: Characteristic spatial features of the Bijlmermeer (April 1976)

Source: Arehive Stedelijke Woningdienst Amsterdam (1) Stedelijke Woningdienst Amsterdann

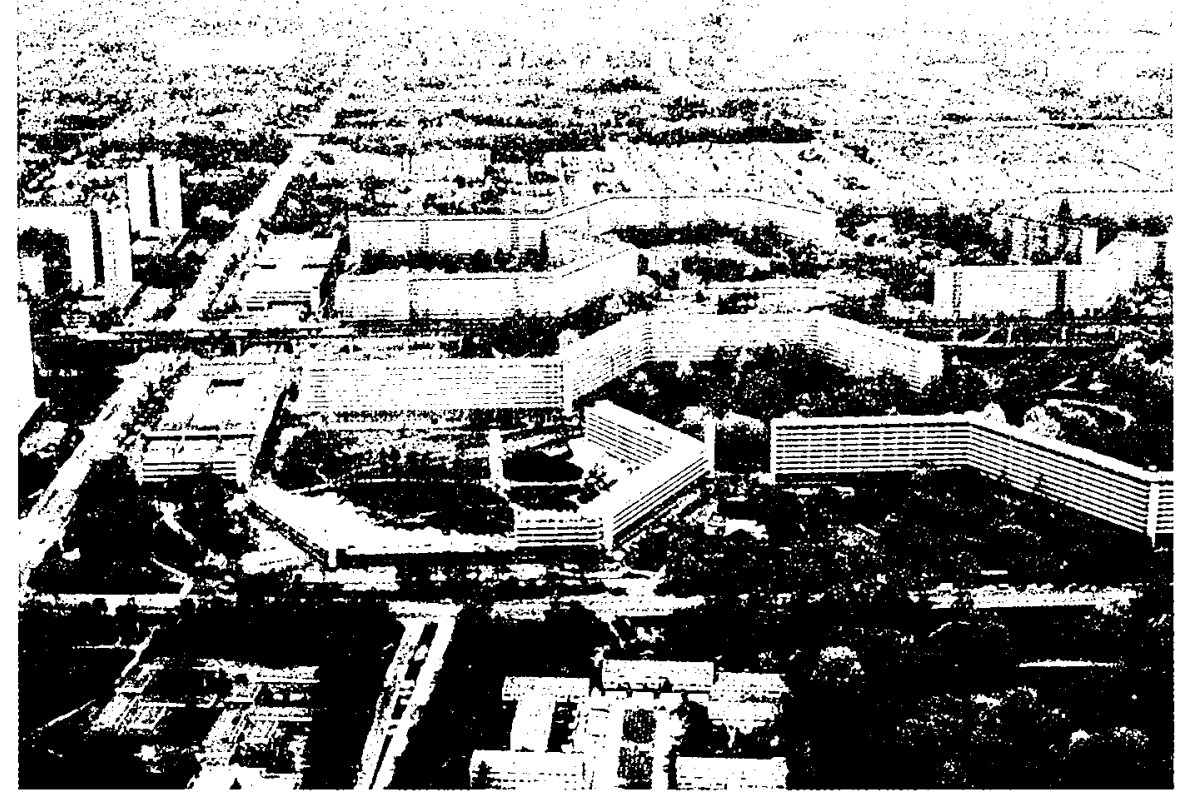

Figure 1.6: Demolished apartment building Bijlmermeer (Koningshoef) (April 1999) Source: Archive Stedelijke Woningdienst Amsterdim (1) Stedelijke Woningdienst Ansterdam 
The projects described in the vignettes above are indicative of the boom in planning activities and large-scale spatial redesign efforts that characterizes the 1990s in the Netherlands (Figure 1.7 depicts a map of the Netherlands, indicating Utrecht, Maastricht and Amsterdam)." Remarkably. fairly recent projects, built in the 1960s, have already become subject to remodelling, face-lifting, or even demolition.' Because ideas about the role of cars in cities, trends in architecture. and the spatial planning of urban areas changed profoundly, many large-scale planning interventions of the 1960s were bassically written off as "failures" in the 1990s.

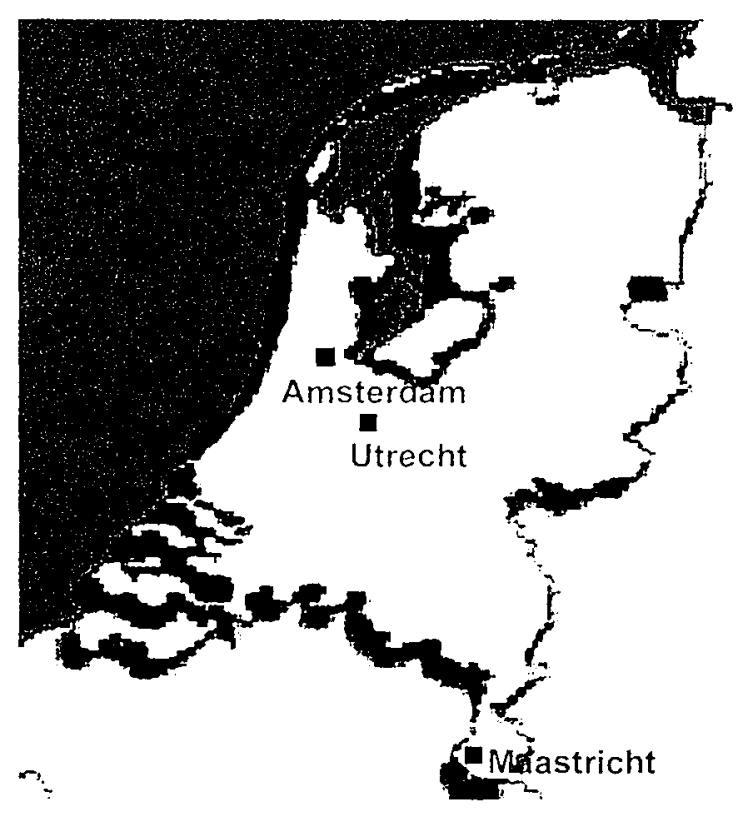

Figure 1.7: Map of the Netherlands

In the Netherlands, where (building) space is perceived to be scarce, the tension between new developments and old structures is felt most dramatically in attempts at redesigning established urban space. In many cases, of course, existing structures will have to be removed or destroyed in order to facilitate new development. Redesign plans play an important role in public debates because many of them have far-reaching consequences for people's daily lives. With good reason, the prominent Dutch journalist H.J.A. Hofland once claimed that in the Netherlands "national conflicts are about space"." As a result, many plans remain controversial for a long period of time before a compromise is reached and even comparatively minor redesign projects may turn into money-gobbling and time-consuming affairs.

The present wide range of planning initiatives and activities in the Netherlands confirms the image of city building as a continuous, on-going process: cities are in a process of being built and re-built all the time; they are never finished but always under construction, always in a process of being realized. Many plans to redesign urban space assume an almost infinite malleability of the existing uban configuration. 
Urban historian Josef Konvitz claimed for example that "Nothing may look less likely to change in a radical way than the status quo in city building, but nothing else may be more likely." It seems counter-intuitive to change cities. but nevertheless they change continuously. But despite the fact that cities are considered to be dynamic and flexible spaces, numerous examples illustrate that it is very difficult to radically alter a city`s design: once in place. urban structures become fixed, obdurate, soon securely anchored in their own history as well as in the histories of the surrounding structures. Objects and facilities that define urban space have a tendency to coagulate, to all become part of one amorphous whole. As a consequence, urban artifacts that are remnants of earlier planning decisions the logic of which is no longer applicable, may prove to be annoying obstacles for those who aspire to bring about urban innovation.

This study is not intented to provide tools for judging the desirability of either changing urban structures or maintaining them. It is not my intention to argue for the necessity to change cities, or to make a strong plea for their preservation. The central concern in this study is more theoretically inspired (see below) and is directly geared toward the confrontation between "new" urban development plans and "old" urban structures: How can cities be adapted to accommodate newly conceived ideas and policies? Why do urban structures maintain their obduracy despite efforts at urban innovation? How do special interest groups and politicians deploy strategies to change what seemed solidly in place or to hold on to what has become contested? This tension between the dynamics and malleability of urban space on the one hand and its hardness and obduracy on the other provides the focus of this study.

The most obvious examples of obduracy in urban contexts involve buildings. facilities, or structures that have never been contested; they have simply "been there" all the time, noticed by few or never in conflict with other potential uses of their location. on account of which they persisted. Given the angle of this study, these sites are not the most interesting. Instead, my focus is on urban sites and structures that have become subjected to what I will refer to as "unbuilding activities": those locations or elements in cities that are disputed or contested or that. at some point in time, were included in redesign plans. The obduracy of urban structures is "tested" in efforts at "unbuilding" them. Debates about redesigning cities (or parts thereof) are infused with questions about the flexibility or obduracy of its elements. To be sure, not all the existing elements of a city are equally contestable, nor is the intensity of particular debates the same in every case or at every stage of the planning process. Yet by concentrating on attempts at city renewal, we should be able to gain insight into the circumstances under which urban change eventually becomes possible.

I will concentrate on these tensions between obduracy and change in three Dutch urban redesign projects: the city center facelift as part of the Utrecht City Project, the highway reconstruction in Maastricht, and the spatial renewal of the Bijlmermeer. In the selection of these projects, I tried to find a balance between homogeneity and heterogeneity: the case studies should have enough in common to be comparable, but they should be different enough to allow for interesting generalizations. The heterogeneity is guaranteed by chosing three different urban sites: a downtown area (Hoog Catharijne), a city highway (Maastricht) and a suburban district (Bijlmermeer). Moreover, the three empirical examples are unique in themselves: Hoog Catharijne was the first large-scale reconstruction of a downtown 
space in the Netherlands in which the city co-operated with a private building company. Afterwards it became an example for many other similar projects in other Dutch cities. The highway in Malastricht is one of the last stretches of the Dutch highway system that runs through a densely populated part of town. The fact that the highway is fully encapsulated by the city. which itself is locked into the Maas River valley, results in extremely challenging redesign problems. The Bijlmermeer is unique since it is the one of the few city districts in the Netherlands that has been built according to strictly applied modernist design principles, resulting in large-scale identical high-rise apartment buildings, a separation of traffic flows. and huge public areas of car-free zones."

Despite the uniqueness of each of the projects and the obvious differences between them. there are some similarities between them that make it interesting to put them together in one book. The first concerns the historical period under study: These projects were each originally planned and built roughly between the late 1950s and early 1970s, and while their redesign or reconstruction is currently in variable stages of development, none of them is completed. Secondly, the case studies are characterized by several comparable themes: the role of infrastructure in relation to urban planning. issues of social safety, criminality and liveability, housing and demolition issues, mobility, the role of the government and national policies, public-private partnerships. and so forth. In addition, all three projects are closely intertwined with Dutch middle class life and their very existence can even be considered as motivated by its provocation: the highway stretch that cuts through Maastricht is regulated by a series of traffic signals and this interrupts the fluid passage of the annual exodus of Dutch families who in their cars and caravans first have to get past Malastricht, before they can truly begin dreaming of a carefree summer holiday in the south of France; Hoog Catharijne, for some the national symbol of drabness, has certainly not become a more appealing urban Moloch over the years and, moreover, it began to be increasingly frecuented by drunks, addicts, and homeless people; and the Bijlmer, built for neat middle class families later became the Dutch equivalent of a socially degraded, impoverished neighborhood, rife with crime and illegal drug activity. Finally, the fact that the projects I focus on are all Dutch makes it easier to compare them. It offers the possibility to be more precise and specific about the particular Dutch cultural and socio-political context within which these projects figure.

On the basis of these case studies a number of questions can be empirically analyzed: What happened when the Utrecht City Project was confronted with the obduracy of Hoog Catharijne? How did it affect the City Project's ideas and priorities? To what extent did the actors involved succeed in changing the seemingly obdurate design of Hoog Catharijne? Why did the existing structures of the highway that cuts through Maastricht maintain their obduracy despite all the efforts to construct a tunnel? Why was the demolition of the Bijlmermeer (or part thereof) initially out of the question and why have radical changes of its original town planning structures nevertheless become a reality since 1992? How and to what extent do the proponents of the Bijlmer Museum succeed in their struggle for conserving the original town planning structures at least in part?

The empirical analysis of the tension between obduracy and change in these urban redesign projects is the focus of chapters 3,4 and 5. But my interest in this study 
is not solely geared toward strictly empirical concerns: the issuc of obduracy and change informs one of the current theoretical debates in Science, Technology and Society studics (STS). How, then, can recent conceptualizations of obduracy of technology help to understand the tension between obduracy and change in cities?

\section{Obduracy of technology}

If one characteristic of technology seems obvious, it is its obduracy and stability. Once the high voltage electricity distribution system is in place, it is hardly conceivable to deconstruct it and shift to a decentralized system of windmill power generation; once a city's downtown area, including all its buildings, roads, and distribution networks, is there, it displays obduracy and offers resistance to change. Given the complexity and far-reaching implications of this reality, it comes as no surprise that technology's obduracy and its effects upon socicty have been a major concern in technology studies. if not the prevalent one.

Yet in the mid-1980s, constructivists started to criticize the technological determinist assumptions underpinning this type of work. In its strongest version technological determinism comprises two assumptions: (1) technology develops automomousty, and (2) technology is the most important determinant of societal developments." Historians and sociologists of technology started to investigate the way socicty shapes technology, rather than the other way around." The idea of technology as an autonomous and unchangeable force was no longer taken for granted.

In their reaction against technological determinism, scholars made choices that shifted attention away from the obduracy of technology. They started to focus their research on the "micro level" of technological change. Thomas Misa indeed has argued that technological determinist statements are less likely to be formulated in studies that focus on a micro level than in studies that take a macro level approach. "In the 1980s. STS-scholars primarily highlighted the early phases of an artifact's development. Thus they convincingly demonstrated the malleability of technology and the role of contingency in the outcome of a technological construction process. In addition, researchers focused on relatively specific, isolated, self-contained artifacts. In studies of concrete artifacts, questions about endurance or changeability are less likely to emerge than in studies of large complex technical systems of which the obdurate character is more obvious." Even in studies of large technological systems and networks, authors usually stress their dynamic character. Jane Summerton, for instance. claims that: "periods of stability in technical systems and networks are typically only provisional." Consequently, constructivists of the 1980 s, in their urge to oppose technological determinism, ended up neglecting the obdurate, resistant character of technology.

This negligence of the obduracy theme has recently been recognized. Wiebe Bijker, for example, suggests that

The impact theme almost disappeared from view and technology seemed merely a social construct that could not appear in an obdurate. transformation resisting. and society shaping form.' 
And Sally Wyatt argues that

in stressing the social nature of the process of technical design and choice. the notion that 'anything is possible' has tatien hold. Litte space has been feft for exploring the social and lechnical limits to what is indeed possible."

Recently. Donald MacKenzie and Judy Wajcman also pointed out that "what is being shaped in the social shaping of artifacts is no mere thought-stuff, but obdurate physical reality." They criticize the "social construction" metaphor because it "is too prone to misconception that there was nothing real and obdurate about what was constructed". After STS-scholars have convincingly argued the socially shaped character of technology. it is once again relevant. as I will demonstrate in this study, to put the issue of technology's obduracy back on the research agenda.

It seems valid to argue. however. that constructivist approaches, such as the actor network theory. the large technical systems approach and SCOT (Social Construction of Technology), have acknowledged the obduracy of technology all along, even if their primary focus was on the malleability of technology. Instead of explaining technology's obduracy by claiming that technology develops autonomously, constructivists claim that obduracy is the result of social and cultural processes. As historian of technology John Staudenmaier puts it:

Far from having an independent and necessary dynamism of its own. lechnical design has no force whatever unless it has become embodied in the choices and commitments of some set of cultural institutions or individuals. Thus the lechnology-culture relationship is intrinsically mutual."

Staudemmaier identifies a number of "cultural" explanations for technology's obduracy that are discussed in articles published in Techmology and Culture between 1959 and 1980. One explanation concerns the "enduring nature of existing technological concepts." If a certain defintion of a technological concept becomes dominant. it will influence later technologies: it will generate new technologies that fit the definition. Moreover. if this definition is widely accepted. it will be difficult for engineers and others who are involved in technological development to imagine radically different alternative technologies. As another explanation of technology's obduracy. Staudenmaier observes that existing technological artifacts are not discarded - even when better artifacts are or become available:

The impetus and direction of technological momentum are often due to the sheer durability of a technology that exerts an ongoing cultural and technical influence simply because it is "there" and because people have come to depend on its being there."

Other factors that may cause obduracy of technology are governmental policies and vested financial interests. Governments play a role in constraining some technologies and fostering others by laws, rules and policy-decisions. After a company adopts and 
invests in a specific technology, it is not likely to contribute to changing the course of this technology`s development.

Constructivist approaches in the 1980 s further conceptualized the cultural explanations of technology's obduracy. In Chapter 2, I will review different conceptualizations and explanations of technology's obduracy in technology studies, urban studies (urban history, history of architecture), and economic approaches of technology from the 1980s until the present. On the basis of the case studies that will be presented in chapters 3 to 5 , I seek to refine various theoretical concerns about the role of obduracy in urban sociotechnical change. In contrast to earlier STS-studies that focused on the early stages of technological development. I will concentrate on the process that involves the negotiations and attempts at undoing the sociotechnical status quo in a city, changing the taken-for-grantedness of its reality, making its obduracy flexible. Evidently. for a proper understanding of the links between the obduracy of technology and urban redesign processes, it is also imperative to conceptualize the relationship between technological developments and urban processes. In this book I shall indeed view the city as one large technological artifact. To what extent, then, are existing theories of technology in STS relevant for the analysis of such a large technological artifact as the city?

\title{
Technology and the city
}

Studying cities makes clear how much our daily lives are pervaded by technologies. Roads, buildings, bridges, tumnels, transportation facilities, communication systems, all are integral elements of our contemporary packed and cluttered expanding urban spaces. Cities, viewed as gigantic living organisms, embody the greatest concentration of technical networks. Urban historians were among the first to acknowledge the importance of technology in the city. As Joel Tarr and Gabriel Dupuy point out:

\begin{abstract}
Today, what we call the urban infrestructure provides the technological "sinews" of the modern metropolitan area: its road. bridge and transit networks: its water and sewer lines and waste-disposal facilities; and its power and communication systems. These "sinews" guide and facilitate urban functioning and urban life in a multitude of ways (...). The infrastructure includes not only networks but also structures and machines."
\end{abstract}

Lewis Mumford, urban historian and historian of technology, was among the first to emphasize the relationship between the historical development of cities and the invention of "megamachines"-invisible systems that consist of interchangeable mechanical, institutional, and human parts and that are centrally organized and controlled." He argued that the development of cities and the flourishing of the megamachine are indissolubly connected: the urban environment was a precondition for the development of the megamachine, and the city, in turn, was made possible only by the invention of the machine." Moreover, in twentieth-century literature, film, and science, the city as a manufactured, artificial space became a standard theme.

It is therefore surprising that in STS so little attention has been paid to the 
city-neither to the city per se. nor to the city as a strategic research site. In a recent article in Techology and Culture, Julie Johnson-McGrath noted that "only a handful of booklength-works have addressed the shape and shaping of urban technology. "wo Simon Guy, Stephen Graham and Simon Marvin posit that "since Lewis Mumford's path-breaking books addressing the wider links between ... lechnologies and urban history .... only a few urban historians have attempted to understand how cities and technical networks co-evolve." They explain this lack of attention for technical networks in the cily, such as sewer systems, with reference to the "taken for grantedness" of these systems---they have become "black boxed". Although citics depend very much on the functioning of these networks. they are frequently invisible, which is why they tend to be ignored. ${ }^{3 x}$ They only seem to attract attention when they fait.

Studies on large technical systems (LTS) are primarily geared toward the role of technological networks like electricity. transport and waste networks. The city as such is hardly mentioned however. The authors appear mainly interested in how these networks were built and how the various actors took part in the development of new technologies. Technological systems and networks serve as the basic category of analysis in these studies. Rather than being the focus, the city functions as a mere locus in this research." Although the founding father of the system approach in the history of technology. Thomas Hughes, situated his analysis of electric power systems in cities," many of his followers have not elaborated on this theme."

This lack of attention for the relations between cities and technologies is regrettable, because, as Johnson-McGrath correctly argues, urban technologies are

artifacts whose use and design are deeply embedded in and reflective of the values of urban culure. These antifacts have politics. economics. geography. and socjoeconomic class. and the study of them. so easily done in vivo and in situ. offers one of the most accessible, yet richly textured means of studying technology. There is, in other words. ample reason for putting the city on the STS agenda, both ats at strategic research site and as an exemplar of technological culture.

Although not much attention has been paid to city-technology relations within STS. this subject is addressed occasionally in other academic disciplines. "Since the 1970s, urban historians have been most committed to studying the history of cities and technologies. A number of their early studies, though, have been justly criticized for their technological determinist overtones. "In a substantial number of the literature on citics published before the 1980s, technology is implicitly considered as an exogenous force that directly influences society. In a review article, Josef Konvitz, Mark Rose and Joel Tarr point out that urban historians viewed machines in the city as examples of irresistible technological progress. " They described technology in terms of its effects on the city and society as a whole. while devoting little attention to the question how specific urban circumstances shaped the design of technologies. In many studies. technology is reduced to a neutral, tool-like instrument. Mark Rose and John Clark, for instance, put forward that urban scholars address technology "only rarely and usually only abstractly"." Another critique of earlier studies is that historical scholarship on the role of technology in cities used to focus in particular on technologies that 
contributed to the efficient functioning of cities and that improved the quality of city life. A direct consequence of this approach was that "historians (...) have been fairly consistent in treating the city as a kind of plastic, something capable of altering its own shape and functions in response to the imperatives of atutonomous machines and systems"." Later on, overly deterministic accounts of technology's role in cities were criticized within urban history and urban sociology." Historian Eric Monkkonen, for example, made the claim that: "technology is far less significant in determining our urban history than most people allow."

After 1980, the "social shaping of technology" approach gained prominence in urban studies as well as in STS. Scholars in the field of urban history started to analyze the social shaping of urban technology rather than the effects of technology. Konvitz et al. argue that from the 1960s on, some historians began to pay attention to the way public choices inlluence urban and technological developments. In the late 1970s. politics and public policy came to be considered influential in the shaping of cities and technologies." Furthermore, the collection on various urban technologies, edited by Tarr and Dupuy, contains revealing examples of scholarly work that emphasizes the major factors in shaping urban technology. In the section on transportation. for example. the authors indicate the factors that helped shape urban transportation technologies, including supply and demand factors, the role of cultural-aesthetic judgments regarding new technologies, institutional arangements and vested interests, and the role of transportation companies in promoting technological innovations." And, finally, at the beginning of one of his important publications on the evolution of urban infrastructure, Tarr significantly points out that the model of the city embraced throughout the book "views cities and urbanization as arising from the interaction of technology and society." It will be clear, then, that a number of these more recent studies are most appropriately situated at the intersection of STS and urban studies."

The best of these studies of city-technology relations show the complexity and heterogeneity of processes of urban sociotechnical development. One example is a study by urban historian Christine Rosen in which she describes the attempts of city planners to make radical adjustments in the infrastructure of Chicago and Boston after these cities partly burnt down in the great fires of 1871 and 1872 , respectively. "These changes, aimed at the renovation and expansion of the existing infrastructure. only met with linited success at most. Rosen explains why. Assuming that both economic and political factors played a role in the explanation of the problems of changing the infrastructure. she combines two disciplinary approaches, economic analysis and political analysis. Next, she argues that a number of economic, political, material, and cultural "frictions" interrupted and delayed the process of change: given the high costs of urban change, funding was an important factor; due to the space-consuming character of infrastructural facilities there was a lack of space in cities: decision processes were slowed down by bureatucratic regulations; the city governments had a monopoly position with regard to public works; there was unwillingness to expand the new infrastructure to poorer parts of the city; and citizens and special interest groups organized all sorts of lobbies. Cultural factors, mainly so-called "privatistic values", further added to these practical, political, and economic obstacles to change. In this way, Rosen succeeds in elucidating how a wide range of factors contributed 10 a laborious urban reconstruction process. The main lesson to be learnt from this example 
is that the study of urban change and redevelopment can benefit from an interdisciplinary approach that does justice to the heterogeneity of cities.

An example of a study that succeeds even better in showing the complexities and multifacetedness of urban redesign is Thomas Hughes's study of the Boston Central Tumnel/Artery Project, locally nicknamed "The Big Dig". "W This project started in the 1980 s and is the largest urban highway project of the United States, scheduled for completion in 20(14. The present design, an elevated highway, was constructed in 1959. but traffic increased, congestion aggravated and the highway formed a barrier between two parts of the city. Hughes analyzes the redesign process. He pays particular attention to a controversy about the design for a bridge across the Charles River (mockingly called "Scheme $Z$ " because it was the twenty-sixth variant that had been studied). Scheme $Z$ cncountered a lot of resistance from Boston citizens because of its hugeness and ugliness. Yet the plan was actually based on a very careful design, laking into account many factors: it followed federal highway requirements, a minimal amount of detours would be necessary during construction, and it avoided the polluting solution of river tumelling. Nevertheless, a review committee (consisting of environmental groups, the chamber of commerce, architects, town planners, and others), especially put logether for this purpose, came up with a radically alternative design: a tumnel. Finally, when it came to a decision, the Massachusetts Secretary of Transportation chose a bridge solution because of its environmental friendliness, the extra time it would take to construct a tumnel, and the added costs of a tunnel.

By elaborating on the design choices and other decisions that were made at various stages of the project. the role and ideas of specific actors in this process, Hughes opens the black box of urban technology. Avoiding the pitfalls of technological determinist or economic reductionist explanations. Hughes demonstrates how the project was socially constructed as a series of public negotiations. His book also underscores that detailed descriptions are needed to convincingly show the heterogeneity and "messy complexity" that is so characteristic of projects of this size.

A third example of a valuable recent study of the relations between urban space and technological change is the book by urban historian Clay McShane Dow'n the Asphalt Path. The Automobile and the American City." McShane analyzes the emergence of the automobile in American cities, framing his discussion as a critique of technological determinist analyses of the development of the car in American cities. Countering the standard view that the car developed "logically and almost inevitably from the invention of the internal combustion engine"s: the author points out that the automobile technology emerged as a result of changes in American urban culture, and that the car, in turn, deeply influenced the configuration of cities.

McShane relates the development of the car to changes in the public perception of the function of streets, arguing that initially streets were largely viewed as a meeting place, a recreational and social public space, but that after the arrival of the automobile this space became almost exclusively used as a transportation domain." Moreover, citizens came to view the car as an icon of liberation and an object of status and social prestige. This helped diminishing the resistance of citizens to cars. Cars were considered a solution to various health and environmental problems in cities: they would stop the pollution from horses, they would contribute to public health since cars created less noise and less dust, and they would improve public safety because cars 
could more easily avoid pedestrians. The automobile was also seen as a solution to social problems: many people saw the automobile as a technology that would contribute to realizing the ideal of suburban life and hence the liberation of the middle class. In this way, McShane convincingly brings home the idea that the automobile is more than just a machine. His analysis of how gender stereotypes play a role in the popular imagination about cars. how they became a status object for men in particular. further underscores this point. Drivers were usually depicted als male, and in advertisements the necessity of physical strength for driving a car was emphasized. Significantly. in his last chapter. MeShane demonstrates how the emergence of the automobile gave rise to "utopian" plans for radical reconstructions of cities and how. on a more pragmatic level, it led to the widening of streets, repavements, and the building of bridges in cities. Both variants (the "utopian" and the "incremental" approach) assumed that it was possible to reconcile the existing design of cities with the challenges and intrusions of automobility.

A full grasp of the developments McShane describes only becomes possible if technology and (urban) culture are seen as mutually constitutive. Far from neglecting the particular urban context of technologies, McShane's study shows that cities provide a crucial context for the emergence of new technologies and that, conversely, technologies have had great impacts on the configuration of cities as well as on city life itself.

The most important theoretical concern in these three studies for my own study is that they do not simply address the impact of technologies on the city. but that they assume an interaction between the two. Urban innovation, conceived as a mode of sociotechnical change, involves a laborious, time-consuming, and precarious process, marked by the delicate interplay of a variety of social, technical, cultural, and economic factors. Rosen's study tells us that by focusing on only one or two of these factors, urban change and redevelopment can only be poorly and incompletely understood. By concentrating on the actors involved, their ideals, assumptions and cultural values, Hughes's study convincingly demonstrates how urban technologies are shaped and how specific ideas are always built into urban design. In McShane's study, the city is both locus and focus. His work stresses the idea that urban change and sociotechnical innovation mutually inform each other.

My own study of the tension between sociotechnical change and urban renewal will take the city as a basic unit of analysis. A city, conceptualized as a sociotechnological artifact, consists of a wide array of erratic and heterogeneous elements that all need to be taken into account, if at least we are to begin to understand its complexity more comprehensively. Of course, urban technologies (like other technologies) are never purely technical-they form a "seamless web" of material and social clements. I will stress the reciprocity of city-technology relations and theorize technology as a cultural force that concurrently shapes the urban context and is being shaped by it. Because focusing on either the city or urban technology is shown to be an unproductive venture, cities and technologies are conceptualized as joint. interconnected categories-at perspective that will be developed, refined, and brought sharper into focus in the course of this study.

This study of cities from a constructivist perspective starts from a broad definition of technology, using the three layers of meaning of technology that 
MacKenzie and Wajcman distinguish. "First. technology can have the meaning of the physical antifacts. In the case of cities one can think of streets, apartment buildings, traffic installations and car parks. In cities, urban artifacts and technological systems are often interwoven. Technological systems in cities include for example highway systems, electrical power systems, and water supply. The second meaning refers to technology as human activities, such as making strects and building houses. The third meaning concerns the knowledge that is necessary to make cities. buildings, and infrastructure. My study may thus address a wide range of urban technologies. Furthermore. I view town planning as a process of sociotechnical change. Chapters 3. 4 and 5. as alrealdy pointed out above, will also specifically be devoted to a discussion of three major processes of urban sociotechnical change the Netherlands: these three case studies are all geared toward an exploration of obduracy as a central concept in technology studies.

Finally. I will conclude this introductory chapter by summing up the three goals of this dissertation. The first is to analyze the tension between obduracy and change in three major urban redesign projects in the Netherlands. covering the period between the 1960s and the 1990)s. The second goal is to specifically contribute to the theoretical understanding of the role of obduracy in urban sociotechnical change. As my first goal has strong historical overtones, my second goal has a decidedly theoretical orientation. My third goal is to bring the city into the limelight of Science. Technological and Society studies and to introduce STS to urban scholars. I will try to find out to what extent STS concepts can be useful to investigate processes of urban sociotechnical change. 


\section{Obduracy of Sociotechnology: Four Theoretical Conceptions}

In this chapter, I will review different conceptualizations and explanations of technology's obduracy that since the 1980s have been advanced in Science, Technology and Society studies, studies of the city, and economic approaches of technology.' Based on an analysis of major studies in these areas, four different conceptions of technology's obduracy can be identified: (1) material obduracy; (2) obduracy related to dominant ways of thinking and interacting; (3) obduracy explained by embeddedness; (4) obduracy as constituted by persistent traditions. Although these four conceptions of obduracy are closely interrelated and even overlap in some respects, each category emphasizes different aspects of obduracy, or foregrounds other explanatory mechanisms in the constitution of obduracy. My aim in this chapter is not to argue which view of obduracy is preferable, but to bring out the complexities of the four conceptions in terms of the issues and questions they address or, for that matter, fail to address. This specifically means that I will focus my discussion on the set of concepts and metaphors used in the various views of obduracy, the explanatory mechanisms they rely on, their disciplinary backgrounds or intellectual traditions, and the types of explanations.

\section{Material obduracy}

The physical and material aspects of obduracy play a major role in studies of the city. Urban historians Joel Tarr and Josef Konvitz, for instance, refer to the enabling and constraining function of urban infrastructure: whereas a specific infrastructure may facilitate urban change at one point in time, the very same structure may frustrate urban development at a later moment.' They also perceive a tension between various urban structures, such as buildings and sewer systems, in terms of their malleability or adaptability, and between the relative fixity of urban structures and wider social and technological developments. There is "a lack of synchronization between urban infrastructures on the one hand and social and technological development on the other:" Urban structures. Konvitz suggests, rarely keep pace with rapidly changing social, cultural, economic and political developments." Since 1880, many urban structures have been put in place under the assumption that the social, economic and technological context in which they were built would be permanent and stable. These 
structures were designed with a long lifetime in mind. However, according to Konvitz, architects and town planners should be aware of the extent to which cities are subject to continuous economic. social and technological changes. Moreover. they should be attentive to the degree to which urban infrastructure, once implemented, limits the adaptability of cities to such changes: political, cultural, economic and social changes question the established urban structures.

Apart from making distinctions that apply to a specific urban context, urban historians have also observed cultural or international differences in urban changeability. mainly between European and American cities." Germany and France have strong traditions of neatly planned infrastructure, leaving less room for technological innovations and resulting in a more "rigid" urban space. The design and evolution of American cities. by contrast. tends to be influenced more by outside factors, on account of which American cities are also more receptive to radical infrastructure innovation than European cities.

Another major relevant distinction when it comes to the adaptability of cities involves their historicity. In this respect, urban historians have referred to differences between nineteenth-century cities and twentieth-century citics. Konvitz, for example, has argued that "older city building processes allowed for a greater measure of adaptability": Until 1880 , the building of large infrastructural projects, such as sewer systems, was restricted to relatively small parts of the city. This made it easier and relatively cheap to change or adapt them. But the rapid growth of urban infastructure networks in the early iwentieth century seriously limited the overall adaptability of cities. Another reason why nineteenth-century cities were fairly open to adaptation is related to the size of the structures and the building materials used. Way into the nineteenth century, most cities consisted of wooden structures or small stone buildings. As a result, it was relatively easy and profitable to adapt such cities to new infrastructure systems." Characteristic twentieth-century building materials like steel and concrete are much more durable and allow for much larger buildings that are also harder to remove."

However, James Trefil, a physicist writing on cities, argues for an increasing urban malleability made possible by technology: "We are approaching an era in which there really are no more technological limits on the kinds of cities we build. We can build anything we want."" The author claims that "technology sets the limits on what cities can be, defines the general direction in which they will grow." Trefil suggests that cities develop and function according to the laws of nature. There is a limit, for instance, to how high a wooden, stone or steel building can be-a limit that is defined by "interatomic forces." The restrictions to urban change, if there are any at all, are mainly technological. Trefil thus emphasizes the physical or material dimension of obduracy.

Others also address the role of materials in urban change. In his study of the history of urban morphology, James Vance Jr. writes that urban form persists because "the properties of the physical world are basically unchanging; stones are stable entities save under unfortunate and unusually destructive forces." He argues that there is not much difference between the raw materials that were used to build cities by the ancient Greeks and those used in the nineteenth century, but that the rate of change has accelerated in the twentieth century. Vance emphasizes that urban change 
should be understood as an evolutionary. incremental process.

The obduracy of cities is not only explained in terms of physical characteristics, building materials or historical factors, but also in terms of the layout of specific town patterns and city shapes. The well-known urban design theorist Kevin Lynch. for example, argues that physical features of cities may constrain or facilitate change, but that in some cases they are even "the key to future adaptability." "The grid street pattern, for example, has proved to be very adaptable." whereas a hexagonal or triangular grid may be incompatible with newer building methods. A grid street pattern has similar street corners, which allows for a great degree of "interchangeability of locations"

Concerns like these are of course part of the architect's everyday practice. In this context, the Italian architect Aldo Rossi hats written that cities "tend to remain on their axes of development, maintaining the position of their original layout and growing according to the direction and meaning of their older artifacts." Rossi views the city as a collective artifact in which two permanent factors can be identified: housing and monuments. Whereas cities cannot do without housing, the make-up of its network of individual homes and dwellings tends to change over time. Monuments are another specific category of individual artifacts that persist." Rossi argues that despite their material obduracy, there can be a great flexibility in their meaning and use. Stewart Brand, an inventor/designer, biologist, army officer and multi-media artist makes a similar point when analyzing the adaptability of buildings. He argues that they are designed not to adapt: "the whole idea of architecture," as he puts it succinctly, "is permanence.": In another sense, however, the meaning of buildings changes anyway, according to Brand. "because the usages in and around them are changing constantly." A building may be obdurate in a material sense, but its meaning and use can still be flexible.

In his book, Brand makes a distinction between the various layers of buildings that have different life cycles and that change at different paces. His $6-S$ scheme (see Table 2.1) differentiates between the slowest rate of change, which applies to the "site" or geographical setting of a building and which may last forever, and faster changes that occur in other layers. Air conditioning systems, for instance, are usually replaced every 7 to 15 years. The "stuff" in a building, its furniture, changes most rapidly, on a monthly or even daily basis. Brand suggests that the main reasons for changing a building are related to new styles, especially with regard to the building's exterior, the need for technical maintenance or repair, technological developments and the obsolescence of systems in the building. 
Table 2.1: Life cycles of buildings

Source: Based on Brand (1994: 13)

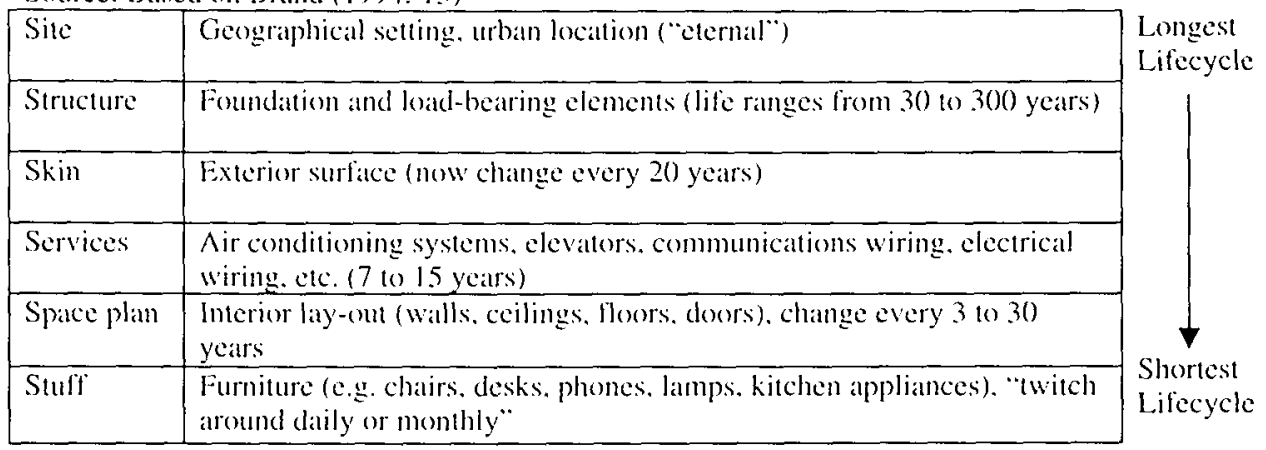

As my discussion of material obduracy suggests, several scholars and critics put emphasis on the physical, material and formal dimensions of obduracy and change in cities. They argue that the material or technological aspects of cities play a crucial role in processes of urban change and even determine the limits of change (Trefil). Most agree that economic, institutional, social, political and cultural factors also play a major role in processes of urban stability and change, but some also indicate that there may be a tension between the rate of change of these factors and the relative fixity of materially embedded urban structures (Tarr, Konvitz). The views and approaches that I discuss in the following sections provide more detailed accounts of the social. economic and cultural causes of obduracy, as well as of the relationship between material/ technological and societal change. The idea that cities, buildings or infrastructures have inherent technical properties that resist change is disputed in the following sections. Although it may not be difficult, technically speaking, to demolish an apartment building or to adapt a city highway, such structures may nevertheless prove to be very obdurate in some "immaterial" sense." Obduracy, then, cannot be explained only with reference to the physical properties of technologies, as a wide range of cultural factors play a role as well.

\section{Dominant ways of thinking}

In this section, I will discuss conceptions of technology's obduracy that focus on the role and strategies of actors involved in the design of technological artifacts, while the constraints posed by the sociotechnical frameworks within which they operate will be addressed in particular. The concepts of this category apply to situations in which town planners, architects, engineers, technology users or other groups are constrained by fixed ways of thinking aind interacting. As a result, it becomes difficult to bring about changes that fall outside the scope of this particular way of thinking. The concepts in this category are generally used to analyze the design and use of specific technological artifacts. As an interactionist conception of obduracy, this category highlights the struggle for dominance between groups of actors with diverging views and opinions. ${ }^{21}$ In relation to specific technological artifacts, examples of this conception of obduracy include Wiebe Bijker's "technological frame", Michael Gorman and W. Bernard 
Carlson's "mental models", and the notion of "worldviews" as found in work by Bermard Truffer and Gregor Duimenberger. The concepts of "technological frame", "professional worldviews" (Cliff Ellis), and the "standard set of solutions" (Eugenie Ladner Birch) have also been applied to town planning design. Specifically, the concepts in this category highlight the significance of users, or "relevant social groups". and inventors when it comes to explaining technology's obduracy.

Wiebe Bijker developed his concept "technological frame".2 in the context of the SCOT-model (Social Construction of Technology)." This model defines the obduracy of a technological artifact as a stage in the artifact's development. In the early 1980s, Bijker and Trevor Pinch formulated the outlines of their sociological model of technological development. They distinguish three stages in the analysis of a technological artifact. In the first stage, the "interpretative flexibility" of an artifact has to be analyzed. The authors argue that an artifact"s technological development should be described from the point of view of various "relevant social groups", because, typically, members of various social groups look differently at an artifact and attribute other meanings to it ("interpretative flexibility"). The second stage consists of analyzing the artifact's stabilization. During the interactions within and between these social groups, one meaning will become dominant after some time: the artifact's interpretative flexibility decreases, its meaning becomes more stable and finally it will have one single dominant meaning. This "closure" of the artifact's interpretative flexibility implies that its meaning will be quite fixed for a period of time. ${ }^{2 .}$ This fixity of meaning results in technology's obduracy. As Bijker puts it: "previous meaning attributions limit the flexibility of later ones, structures are built up, artifacts stabilize, and ensembles become more obdurate." The third stage in the analysis of an artifact's social construction involves relating "the content of a technological artifact to the wider sociopolitical milieu."

Particularly relevant for the analysis of obduracy is Bijker's concept of "technological frame". A technological frame is built up during interactions among relevant social groups. It may consist of goals, problems, problem-solving strategies, standards, current theories, design methods, testing procedures and so forth (see Table 2.2 for a tentative list of elements of a technological frame). ${ }^{27}$ For the analysis of obduracy, it is important to consider the role of artifacts as "exemplars". After closure, an artifact becomes part of a technological frame as a so-called "exemplary artifact":

An artifact in the role of exemplar (that is, after closure. when it is part of a lechnological frame) has become obdurate. The relevant social groups have, in building up the technological frame. invested so much in the artifact that its meaning has become quite fixed-it cannot be changed easily, and it forms part of a hardened network of practices. theories and social institutions. From this time on it may indeed happen that, naively spoken. the artifact "determines" social development."

Besides analyzing the role of artifacts as exemplars when studying obduracy, it is also important to analyze for whom a technological artifact is obdurate and for whom it is not. An actor with a high inclusion in a particular technological frame thinks and interacts very much in terms of that technological frame. For such actors it is difficult to think of altemative technological designs. This may be referred to as 
"closed-in" obduracy. The opposite. "closed-out" obduracy, is possible as well. This occurs when actors have little involvement with a particular technological frame, when they have a "low inclusion". For them, the technology presents a "take-it-or-leave-it" choice. They see no possibilities for variation within a given technological frame, so they are left with the choice of either accepting it or abandoning it. In this way, atcording to Bijker, an artifact can be obdurate in terms of having one fixed meaning or in terms of enabling and constraining interactions and ways of thinking.

Table 2.2: Tentative list of elements of technological frames

(Bijker. 1995b: 125)

\begin{tabular}{|l|}
\hline Goils \\
\hline Key problems \\
\hline Problem-solving strategies \\
\hline Recuirements ob be met by problem solutions \\
\hline Current theories \\
\hline Tacit knowledge \\
\hline Testing procedures \\
\hline Design methods and criteria \\
\hline Users praclice \\
\hline Perceived substitution function \\
\hline Exemplary arteficts \\
\hline
\end{tabular}

Although cities are more complex than singular technological artifacts, Eduardo Aibar and Wiebe Bijker suggest that the SCOT-approach is also applicable to more complex, heterogeneous sociotechnical ensembles such as town planning projects. They analyze the controversies around the Cerdà Plan for the extension of Barcelona between 1854 and 1860 . $^{2 "}$ They consider town planning "as a form of technology, and the city as a kind of artifact." Taking the SCOT-model as their theoretical framework, they analyze the interactions between social groups and their negotiations concerning the extension issue and they describe how technological frames were formed during these interactions. The technological frames consisted of the problems that were considered important by the relevant social groups, the various solutions to these problems and the extension plans they proposed. In the course of the events, two rival technological frames came into being, referred to as the "engineers" frame" and the "architects" frame". Aibar and Bijker describe the controversy in terms of opposing technological frames that try to become dominant. They argue that in cases where there is no single dominant technological frame. generally an "amortization of vested interests" takes place. This is what happened in Barcelona. Aibar and Bijker show how the final layout of the city "got the mobility and easy traffic atributes from the engineers" frame, while hierarchy and high density of buildings were achievements of the architects' frame".:

Although Gorman and Carlson's "mental model" resembles Bijker's technological frame. they make a distinction between mental models, mechanical representations and problem-solving strategies or heuristics. Mechanical representations are very precise images of technological artifacts, whereas mental models are often more diffuse, cognitive ideas. Mental models especially address the inventor or designer. Technological frames also apply to other social groups involved ,in the development of technological artifacts. Moreover, "technological frame" is a 
broader concept, since mental models mainly consist of inventors" ideas about the luture working of atifacts. Gorman and Carlson emphasize that mental models "are shaped by the inventors in response to social and economic pressures as well as personal preferences"."

In their article. Gorman and Carlson discuss how Alexander Graham Bell and Thomas Edison invented the telephone. Bell and Edison each formulated a different conception of the telephone. A comparison of the mental models the inventors revealed differences in their cognitive style: Bell can be seen as a "top down" inventor who tested several variations and altematives in his mind, whereas Edison used a "bottom up" strategy that stated from mechanical representations that ultimately led to the telephone. Like technological frames. mental models may also be a source of technology's obduracy. Gorman and Carlson suggest that existing mental models can become so constraining that only a relative outsider can move beyond them and develop fresh ideas. Specifically, they refer to the dominant role of the so-called "Reis telephone" in the mental model of the telegraph community, a model that was rejected by outsider Alexander Graham Bell who subsequently succeeded in developing an alternative."

The important role of outsiders in overcoming obduracy and bringing about radical innovations is also emphasized in an article by Bernard Truffer and Gregor Diirrenberger about the development of lightweight cars." According to Truffer and Diirrenberger, "worldviews" can serve as important obstacles for radical innovations: "the search for novelty may be hindered by all too well-trained behaviors and worldviews"." Because it is not uncommon for such views to reflect "the rigidities of an industrial tradition". the authors underscore the significance of employing young engineers who have not yet been influenced too much by traditional values, especially in radically innovative projects.

Scholars who studied processes of urban change advance a similar view. Historian of planning Cliff Ellis. for instance, has looked at the role of "professional worldviews" in the process of American city planning, in particular the design of urban freeways between 1930 and 1970. "He argues that on account of differences in protessional training members of the various professional groups involved in freeway planning (architects. engincers, urban planners and landscape architects) held different worldviews. which in turn led to their proposal of different design solutions:

The involved professionals used different ideals and images to advance their goals: intellectual tools acquired through education. professional socialization. and daty pratetice. Professional worldviews shaped the styles of research. the gencration of alcematives. and the presentation of proposals to the wider public."

Highway engineers. for example. tried to simplify the problem of highwaly design and make it calculable by developing engineering standards and using computer models. Land-use planners divided the city in urban zones that had to be defined in legal terms and in terms of the activities that could be performed in various parts of the city. Urban designers interpreted the city as a combination of three-dimensional structures, imbued with symbolic meanings. According to Ellis, these worldviews - "as embodied in methodologies, recurring solutions, standards, habitual ways of framing a 


\section{Chapter 2: Obduracy of Sociotechology}

problem" - are difficult to ignore since they are closely related to the professional's urge for (intellectual) influence and a good reputation.

Eugenic Ladner Birch has described the role of four groups of actors in early American planning practices: local residents, city planning commission members, town govermment officials and professional town plaming advisers. According to Birch, the latter group, united in the American City Planning Institute, would establish the "dominant planning ideology" in the United States." She refers to the important role of a "standard set of solutions" used by American city planners in the early twenticth century." They adapted solutions that were used in European cities, such as German zoning. the British garden city concepts, the French boulevard and infrastructure construction, and Italian renaissance urban design."

As my discussion suggests, the various approaches have in common that they all emphasize the constraining role of dominant ways of thinking - including values, professional conventions, views of the world, typical solutions, problem definitions, etcetera - for specific groups of actors. When certain ways of thinking have been built up around an artifact, it becomes difficult to ignore them, let alone change them. Implicit in these approaches is the assumption that because certain ways of thinking have a narrow focus or are difficult to adapt, the technology involved will become obdurate or only have a limited flexibility. In contrast to the views on material obduracy that were discussed in the previous section. the approaches discussed in this section provide more constructivist conceptions of obduracy. This means that obduracy, instead of being caused by material factors alone, is the result of interactions between social groups - interactions that are constrained by specific ways of thinking. In the next section, I will discuss conceptions that seek to explain obduracy by focusing on the close interrelationship between the various heterogeneous elements that make up a network, system or ensemble.

\section{Embeddedness}

Within STS, technology is often conceptualized as part of a greater whole. Thus, technological artifacts are not analyzed in isolation, but as part of a larger system, network or ensemble. STS-scholars argue that society plays a crucial role in the shaping of technology and that, conversely, technological developments have an important impact on society; they observe, in other words, a "co-evolution" of technological and societal developments. Applied to the built environment, this idea of co-evolution highlights that building cities implies the shaping of society, or that "civil engineering is also social engineering"." At the same time, utopian ideals, cultural values, economic considerations and power relations are built into the physical structure of cities; there is always a "social shaping of technology" at work." Thus, cities are never purely technical constructs, but form a "seamless web" of both physical and social elements. In the most radical interpretation, the metaphor of the "seamless web" suggests that the "social" and the "technical" are two sides of the same coin: the technical is socially constructed and the social is technically constructed."

In this approach, the obduracy of technology can be explained precisely because of technology`s embeddedness in sociotechnical systems, actor-networks or 
sociotechnical enscmbles." In this respect. historian of technology Thomas Hughes argues that the building of a system is accompanied by fewer difficulties when it has not yet become linked-up with politics, economics, or other value-systems. ${ }^{47}$ This category involves a relational conception of obduracy: Because the elements of a network are closely interrelated, the changing of one element requires the adaptation of other elements. The extent to which an artifact has become embedded determines its resistance to efforts aimed at changing it. Such efforts may be prompted by usage, societal change. economic demands, zoning schemes, legal regulations, newly developed policies and so forth.

Another explanation for the obduracy of embedded objects is that their presence is no longer questioned or discussed. It turns out that many artifacts are so deeply cmbedded in our technological culture that they are taken for granted and do not attract attention anymore. Sociologist of science Susan Leigh Star gives a good example of such uncontested technology: the red color of traffic lights, meaning, "stop". Although this initially involved an arbitrary decision, it has now become a generally accepted rule of conduct that has become integrated into other networks and symbol systems as well. As a result, it is nearly impossible to change this convention and, most likely. no one will ever even try to do so.

Actor network theorists such as Michel Callon, Bruno Latour, Madeleine Akrich, John Law and Annemarie Mol describe technological development as a process in which more and more social and technical elements become linked up with each other in a network." They investigate the attempts by actors to stabilize that network. But the larger and more intricate a network becomes, the more difficult it will be to reverse its reality. In this way, a slowly evolving order becomes irreversible."

Bruno Latour gives a clear example of how a network became more obdurate and less reversible over time. He describes the controversy in late-nineteenth-century France between the city of Paris and a number of major private railroad companies concerning the subway construction." The socialist city government was looking for a method to guarantee that the railroad companies could not take command of the subway system if a right-wing party were to win the city elections in the future. It found a solution in having subway tunnels built that were narrower than the smallest coaches of the railway companies. Latour shows that the city "shifted their alliance from legal and contractual ones, to stones, earth and concrete". Over the years the subway network expanded, but its initial design became less and less reversible. The obduracy of the subway network became obvious when after seventy years the railroad companies and the subway companies wanted to link their networks. The engineers who were hired to increase the size of a number of these tunnels were basically asked to "undo" what had been decided before. Latour concludes:

What could have been reversed by election seventy years ago, had to be reversed at higher cost. Fach association made by the socialist municipality with earth, concrete and stones had to be unmade, stone after stone, shovel of earth after shovel of earth."

At first sight. philosopher of technology Langdon Winner's famous example of the low bridges of Long Island reflects a similar argument. Winner argues that project developer Robert Moses deliberately designed low bridges across the parkways to the 
Long Island beaches in order to prevent buses, which were normally used by the lower classes and ethnic minorities, from going there. Long after Moses's death the low bridges will continue to produce an exclusionary effect:

\begin{abstract}
Because choices tend to become strongly fixed in material equipment. economic investment. and social habit. the original flexibility vanishes for all practical purposes once the initial commitments are made. In that sense. techonological innowations are similar to legislative acts or political foundings that establish a framework for public order that will endure over many generations."
\end{abstract}

In a recent article. however. sociologist Bernward Joerges strongly criticized both Winner's theoretical assumptions and the story"s historical accuracy." Winner assumes that social intentions atre deliberately built into artifacts and that social order is an automatic consequence of these intentions. Joerges contrasts this theory with radical constructivist theories that emphasize the contingency of actions and their consequences. Latour's example above belongs to Joerges's 'contingency' category: obduracy originates in associations within a network rather than in deliberate intentions. Despite the story's historical flaws, Joerges shows that it. by being told and retold numerous times, has almost acquired the status of a doctrine in STS and urban studies: the story itself became obdurate.

Another example of a technology that proves to be difficult to change because of its embeddedness is the internal combustion engine for cars." Alternative technologies such as electric automobiles have been developed, but they turned out to be unsuccessful. Over the years, the internal combustion engine has become an integral part of a "car system", a web of automobile manufacturers, oil companies, gas stations. roads, users, environmental movements and national, regional and local administrative bodies. Moreover, the fairly slow evolution of this system enhanced the understanding of the technology among users, while compatibility problems were solved by developing a number of additional technologies and "misfits with the societal and political system have been accommodated." These developments expanded the network in which the internal combustion engine became ever more solidly embedded, thus making the system obdurate and increasingly less prone to change.

Implicit in these constructivist views of technological development is a movement from flexibility to inflexibility: technology stabilizes gradually and becomes obdurate. Constructivist work argues that, typically, a sociotechnical ensemble or system becomes more rigid and less flexible during its development. In studies of the management of innovation processes, the "dilemma of control".s represents this line of reasoning: at the start of a technological project it is fairly easy to change its features, but at that point little or nothing is known about the state of the world in which the technology will eventually be implemented. When, at the end of the project, the circumstances in which the technology is embedded are known, the technology cannot be changed anymore."

This dilemma is active at the level of systems, networks or artifacts as a whole, but it is equally possible to distinguish elements with varying degrees of malleability within a single network." John Law, for instance, stresses that the social should not be 
privileged: "Other factors-natural, economic, technical-may be more obdurate than the social and may resist the best efforts ... to reshape them." In addition, Michel Callon argues that the possibility to change a network depends on testing the capacity of the various entities that make-up the actor-network to resist transformation."

A similar take is advanced by John Law and Annemarie Mol. They point out that there are differences in the "durability" of various human and non-human entities that constitute a network. As an example they refer to large blocks of concrete bunkers that were built by order of the Nazis near the Dutch City of Utrecht.": Although the German occupation of the Netherlands ended in 1945. the concrete blocks are still in place. Law and Mol argue that the durability of these bunkers cannot only be explained with reference to the physical properties of concrete. but that concretc should also be considered as part of a network:

\footnotetext{
Suppose we imagine that concrete is not a thing in itself ... instead that it is a set of relations: relations (for instance) with the weather: the molecular forces that make it up: and the reinforcing rods that run through it.":
}

The bunkers still exist, but no longer as part of the Nazi network, a political system that, after all, proved to be "less durable than some of its concrete elements." This may seem like an argument that strictly relies on the concept of material obduracy as a way of explaining their continued presence. However, the bunkers near Utrecht have meanwhile become linked up with other networks as well. They are also "durable" because they have become part of preservationist and environmental protection networks: the bunkers are under a provisional preservation order as war monuments and some of the bunkers are preserved for environmental reasons since they have become habitats for bat populations.".t.

The idea that some elements of a sociotechnical network remain obdurate while other elements change, an issue also raised by urban historian Konvitz (see above), questions the notion of "co-evolution". Such an approach appears to assume that coevolutionary developments of technology and society (of a design and its environment) can be "out-of-phase" during periods of stability. When a network stabilizes and becomes embedded in a wider configuration, it grows less susceptible to influences from outside and it starts to determine its environment. However, the opposite seems true as well. Instead of suggesting that a technological network determines its environment, it is also possible to posit that a technology 's environment wins a victory over technology. Staudenmaier, for instance, argues that embedded technologies will inevitably reach a "senility stage" in which the larger world has changed so much that the technology will become "dysfunctional":

It is inevitable that the technology's life cycle wilt eventually lead to a form of "senility." The term is chosen because of the nature of human senility-the increasing disconnection from one's ambience due to a hardening of the arteries."

Because of the rapid and ongoing changes that are taking place in the world, a technology will not forever retain its harmonious relation with these developments. In other words, then, co-evolution stops at one point, after which the technical design and 
its enviromment do not fit neatly together anymore. According to Staudenmaier this situation can be solved by returning to a new design stage so that a renewed synchronization between design and environment can be established. However, in most cases, the people involved with the "senile" technology will try to harmonize the old design and its environment by "forcing the ambience back into configuration with the old design"."

Writing about the obduracy of physical artifacts in relation to users, actor network theorist Madeleine Akrich introduced the "script" concept: Engineers or designers "inscribe" their ideas and predictions about the world in which an artifact is meant to function into the technical object." In their design of an object engineers define its potential users, their tastes, qualities, purposes and so forth. Thus they have certain assumptions about the world in which the object will be embedded and about how it may develop. Therefore, once the object is brought into the "real world", Akrich suggests, we should investigate the extent to which the user envisioned by the engineer resembles the real user. One way to use this concept is to analyze the way technological artifacts exercise constraints over those who use them. Akrich shows "how technical objects define actors, the space in which they move, and the ways in which they interact". She argues that "the obduracy or plasticity of objects ... is established in the confrontation with users"."

The embeddedness of technological artifacts or networks refers to the difficulty of changing elements of sociotechnical ensembles that have become closely intertwined in the course of time. Changing one element has consequences for (at least part of) the whole ensemble. Obduracy is no intrinsic property of technologies but can only be understood in the context of its ties to other elements within a network. It is possible to differentiate between degrees of obduracy of different elements in a network or system, without a priori assuming that social elements are more obdurate than technical ones and vice versa. Analyzing technology's embeddedness entails more than describing and summing up the elements that constitute a network - more than simply concluding that the more elements there are, the more obdurate an ensemble is. To function as a proper explanation of obduracy, the embeddedness of an artifact in a larger whole has to be understood in its changing historical, political, economic and cultural context. In the next section, obduracy is explained in relation to longer-term processes in which earlier events continue to influence and constrain the further development of a technology for a considerable period of time.

\section{Persistent traditions}

The category of persistent traditions comprises conceptions of obduracy that address the idea that earlicr choices and decisions that keep influencing the development of a technology over a longer period of time. Because of this focus on the longer-term persistence of traditions in sociotechnical change, I call this category enduring. Specifically, the notions of path dependence, trajectories, momentum, and technological regime embody this conception of obduracy. Conceptualizations of patterns in technological development are closely related to the conceptions of obduracy discussed in the previous two sections: they often suggest embeddedness or 
are associated with concepts discussed under "dominant ways of thinking". For this reason, it is sometimes difficult to make a strict categorization. The concepts that explicitly refer to more collective and longer-term inclusions in dominant ways of thinking and that I discussed above, such as "professional worldviews" and "standard sets of solutions", might also have been put in the category of "persistent traditions". These concepts resemble Giovanni Dosi"s approach of "technological paradigms and trajectories" and the notion of "technological regime" (Richard Nelson and Sidney Winter, Arie Rip and René Kemp) that I will discuss in this section. However, the concepts discussed here are less focused on interactions in local contexts.

Path dependence, a metaphor mostly used in economic approaches of technological change, refers to the idea that past events keep influencing the developmental path or trajectory of a technology. Path dependence develops over a longer period of time and suggests that "local, short-term contingencies can exercise lasting effects"." Callon, for example, emphasizes that each decision about technological design is constrained by earlier decisions and that it, in turn, constrains following decisions." Technological decisions that have become materially embedded are the most difficult to change:

Unlike some decisions which always remain possible to revise, those that are materialised in technical commitments ... lead to durable imbalances and the consequent discarding of options which. with hindsight. might have been thought preferable to those actually taken.

Hughes has also indicated that the socially constructed features that became embedded in technical systems in the early stages of their development can have lasting effects."

A clear example of path dependence is given by economist Brian Arthur. He argues that the history of technology has shown that not necessarily the "best" technologies are adopted, but that the always contingent adoption history of a , technology plays an important role. Once a technology becomes almost collectively adopted, much effort will be put in improving it, thereby making it more desirable for an even larger group of potential users." Arthur discusses the example of the QWERTY-keyboard (named after the first six letters of a keyboard's top row). Generally, it is not considered the most ideal keyboard. It was developed during the era of mechanical typewriters as a solution to the recurrent interference of adjoining keys. In the period of personal computers and electronic keyboards, however, this arrangement seemed no longer necessary, and alternative designs were made. But, incidentally, none of these alternatives became widely accepted. So far, then, the QWERTY-keyboard has basically remained unchallenged: its design seems irreversible.

The persistence of certain patterns of technological change may in part be explained by considering the role of the beliefs of engineers and others in this persistence: a technological trajectory can thus be seen as a "self-fulfilling prophecy"." Donald Mackenzie, a sociologist of technology, argues that the beliefs of actors in the progression of a certain technological development become embedded in their behaviour and statistical predictions, and that, as a result, the projected development indeed takes place because it was bound to happen. In this way, the success of a 
technology (cf. QWERTY versus other systems) can be explained at least in part by the collective beliefs of engineers. customers or others who have interests in anticulating its success."

The metaphor of momentum. introduced by Hughes. highlights the role of embeddedness and the role of trajectories in patterned technological development. Even though Hughes himself refers to the similarity of the momentum and trajectory concepts." he uses "momentum" to describe the problems of changing large technological systems during certain stages in its development:

The systematic interaction of men. ideas, and institutions, both technical and nontechnical. led to the development of a supersystem-a sociotechnical one-with matss, movement and direction. An apt metaphor for this movement is "momentum"."

When systems are expanding they acquire momentum. or "dynamic inertia". In this growth process. "reverse salients" and "critical problems" may play a prominent role. The notion of "reverse salients" articulates the idea that some parts of a system may be lagging: they are "out of phase" with the development of other system components. Reverse salients are technical. social or organizational aberrations produced by a system`s inharmonious development: the quick development of one element of a system may cause a slower development of other parts of the system. It is important to identify the underlying critical problems of a reverse salient because they slacken the development of the overall system. Once such critical problems are solved. the system as a whole may start growing again."

Hughes positions his concept of momentum between the two extremes of technological determinism and social constructivism." When a system has acquired momentum this means that in that phase the system tends to resist change. Young. developing technological systems are more receptive to social and cultural influences than older systems. which, in turn, have more impact on their environment. This does not imply that a system in a phase of momentum develops autonomously. As Staudenmaier remarks: "the momentum model understands the very dynamics of technological change ats the result of some technical design embodied within a culture." It is this emphasis on a long-term cultural context that makes this form of obduracy different from the caltegory of embeddedness. Hughes emphasizes how the supportive cultural context of a specific electricity supply system (the "polyphase" system) contributed to the system's momentum in the 1890s. At first. manufacturers reinforced the system's momentum by investing in resources, labor, and factories to produce the necessary equipment for the functioning of the system. At a later stage. educational institutions contributed to the system's development by teaching students the necessary skills to operate the system. These practices were further spread and consolidated by professional journals. After this, research institutes were established to solve the system's "critical problems"." These factors all added to the system"s momentum.

The idea of technological development that follows specific sequences or trajectories is conceptualized in economic approaches of technological change that mostly focus on innovative activities within firms and industries. Kim Clark's notion of "design hierarchies" refers to the practice that designs tend to be refined and 
strengthened within existing concepts. Clark makes a distinction between "movements down the hierarchy". implying a refinement of existing concepts, and "movements up the hierarchy". meaning a deviation from established approaches. Radical innovation takes place when core concepts in the existing hierarchy are contested." James Utterback and Fernando Suárez point at the importance of "dominant (product) designs" that encourage standardization, making them thereby more entrenched." According to Dosi. technological development follows a certain "technological trajectory". A technological trajectory is the direction of change within a "technological paradigm". Such paradigms resemble technological frames and can be defined as an "'outlook", a set of procedures, a definition of the relevant problems and of the specific knowledge related to their solution." Technological paradigms strongly prescribe the direction of technological development: "a technological paradigm ... embodies strong prescriptions on the directions of technical change to pursuc and those to neglect." ${ }^{* * 1}$ As such technological paradigms have powerful "exclusion effects":

The efforts and the technological imagination of engineers and of the organizations they are in are locused in rather precise directions while they are. so to speak. "blind" with respect to other technological possibilities."

Dosi claims that trajectories are mainly selected by technological and economic criteria and, once established, can acquire momentum. It is this emphasis on the longterm role of technological and economic choices and specific patterns ir technological development that makes this conception fit better in this category than in the category of embeddedness.

Whereas Dosi emphasizes the role of economic and institutional factors in the construction of a technological paradigm, other concepts encompass more factors. such as cognitive factors, rules and expectations. Nelson and Winter, for example, have developed the related concept of "technological regime"." They refer to "natural trajectories" specific to a certain technology or technological regime:

Regimes are mainly cognitive and relate to engineers' beliefs about what is feasible or worth pursuing. A regime not only defines boundaries but also trajectories to those boundaries. Boundaries are limits of following various design trajectories."

Recently. sociologists of technology and economists elaborated on the regime concept. Their main contribution involves a broadening of the concept. According to Arie Rip and René Kemp.

a technological regime is the rule-set or grammar embedded in a complex of engineering practices, production process technologies, product characteristics. skills and procedures. ways of handling relevant artifacts and persons. ways of defining problems--all of them embedded in institutions and infrastructures."

Regimes "are a broader, socially embedded version of technological paradigms" and they function as mediators between technologies and the wider technological culture - 
or, as Rip and Kemp say, "sociotechnical landscape" - of which they form part." The authors stress the collective character of technological regimes, which makes it difficult for single actors to change the rules that constitute the basis of a regime. Regimes limit the development of alternatives that do not fit into the existing regime.

Historians of technology Anders Gullberg and Arne Kaijser introduced the notion of "City Building Regime" (CBR) to explain morphological change in urban contexts." The CBR-approach combines elements from Hughes's systems approach and urban regime analysis. Gullberg and Kaijser consider it a disadvantage that the LTS-approach focuses on only one technical system, since they are interested in the interactions between different infrastructure systems in cities. A City Building Regime consists of:

a set of actors and the configuration of co-ordinating mechanisms anong them which produce the major changes in the landscapes of buildings and networks in at specific city region at a given point of time."

Co-ordination is mediated by regulatory systems in the city (legal and organizational instruments) and the political culture (that includes "more subtle" historically grown behavorial rules and conventions). Using this approach, Gullberg and Kaijser try to explain patterns of urban morphological change. With their approach Gullberg and Kaijser rightfully criticize "macro-studies" of cities that describe the development of cities as evolving from "walking cities" to the "tramway city" to the "automotive city". They criticize such an approach for its technological determinism and oversimplification: local and national particularities are not considered relevant in such studies. Gullberg and Kaijser applied their approach to the development of post-war Stockholm in which they identified three subsequent regimes: between 1945 and 1979, the municipal multi-family housing regime; between 1970 and 1985 the private singlefamily housing regime; and between 1985 and 1995 the commercial building regime. The first regime, for instance, was characterized by a strong hierarchical co-ordination and network co-ordination in which the municipality and private partners played a crucial role. It mostly produced multi-family houses. Despite tensions and conflicts within this regime, it was stable and extremely dominant.

Crude notions of path dependence and trajectories as developing according to an internal, "natural" logic have been criticized by STS-scholars, who emphasize the contingent and fluid character of technological development. Sociologist of technology Trevor Pinch has correctly pointed at the "a-symmetric" use of the notion of path dependence by economists, who only invoke history when addressing "inferior" technologies. Pinch, by contrast, proposes a more constructivist variant that focuses both on the paths taken and alternative paths that were not taken." MacKenzie's emphasis on "self-fulfilling prophecies" and the recent elaborations in the regime concept by Rip and Kemp and Gullberg and Kaijser are more constructivist in the sense that they describe "trajectories" or "paths" as being actively constructed or destructed, instead of given by nature.

I already mentioned the explicit importance attached to cultural factors in the explanation of a system's momentum in Hughes's analysis. Rip and Kemp and Gullberg and Kaijser also stress the importance of culture (or political culture in the 
case of Gullberg and Kaijser) in their analysis of the stability of regimes. Historian of technology Rosalind Williams gives an interesting cultural interpretation of persistent traditions in her book Notess on the Underground. By analyzing artificial underground worlds as an "enduring archetype". Williams shows how literary traditions from all over the world have always expressed a concern with the underground, which suggests the persistence of the opposition between surface and depth in our thought. Moreover, she relates the idea of living underground, (in contrast to visiting the underground), to the emergence of science and technology, and claims that its development influenced the narratives about the underground and vice versa:

\begin{abstract}
Events in science and in technology altered the lines of the underground stories. opening up new imaginative possibilities while closing down others. On the other hand. the scientific and technological events were informed by the storyline of the journey to the underwork in quest of truth and power. The significant relationship between literature and science and technology is to be found in this structural congruence of plotlines."'
\end{abstract}

Contemporary developments in town planning and architecture, in particular the trend to build underground, to construct tunnels and subways, and to hide less attractive urban functions, can be understood in relation to the work of the nineteenth-century novelist H.G. Wells. In The Time Machine (1895), Wells wrote about an underground world inhabited by the Morlocks, who operated machines and utilities and a paradise of nature and leisure (inhabited by the Eloi) situated above the surface. Williams shows that this tradition of "putting the less glamorous aspects of civilization underground" reverberates in the work of twentieth-century architects. ${ }^{1.11}$ In their urge to deal with overpopulation and space-consuming distribution networks, roads, central heating infrastructure, and factories, they have turned their gaze to the underground world, so that the surface may still be available for the more pleasurable aspects of life (leisure, recreation, parks, housing, schools and so forth). Such traditions can be enduring in the sense that they are likely to keep influencing choices and decisions of large groups of people.

Another example of the role of persistent traditions in town planning is illustrated in an article by Sally Kitt Chappell. In her study of designs of railway stations in American cities between the 1890s and 1930s, she indicates the importance of four "archetypal designs" for large railway stations." These archetypes were based on existing railway stations and, according to Kitt Chappell, their influence on American architects is clearly noticeable in the architectural design of large stations built in the period thereafter. Over time, new designs would modify the existing archetypes.

For my analysis of obduracy, this focus on the persistence of decisions involving the design and building of (urban) technologies will prove quite useful. This category of explanations of obduracy as constituted by persistent traditions stresses the long-term effect of such decisions on sociotechnology. In contrast to the "interactionist" conceptions of obduracy that were discussed under "dominant ways of thinking", however, the conceptions described in this section do not focus on specific social groups that interact in local contexts. Instead, the emphasis is on the role of 
collectively shared rules and values that transcend local contexts, on culturally rooted traditions that derive their strength from the fact that they are shared by many people. The "technological frame" concept, for instance, allows for actors who have different degrees of inclusion in different frames. but the conceptions of "irreversibility" or "archetype" suggest a more comprehensive or pervasive quality of technological artifacts. It will be evident that this broader cultural conception of obduracy that focuses on persistent traditions enables a further operationalization of the linkages between urban technology and the wider cultural context (ef. my discussion of the third stage of SCOT above). The main contrast with the category of "relational" conceptions of obduracy discussed under "embeddedness", consists of this category"s

"emphasis on longer-term continuities and the idea of patterned technological developmen (e.g. in terms of trajectories), whereas conceptions of embeddedness do not specifically focus on such patterns and long-term (cultural) traditions.

\section{Comparison of the four conceptions of obduracy}

The four conceptions of technology's obduracy described here complement rather than exclude each other. Each category highlights different yet equally relevant interpretations of the phenomenon of obduracy. The four categories are schematically represented in Table 2.3. Although the concepts and metaphors of each category originate in various (sub)disciplines, ranging from architecture and urban studies to the history and sociology of technology and economics. they intersect in many ways. Hughes's concept of momentum, for instance, involves a form of embeddedness, but it also suggests a certain trajectory, whereas Bijker's concept of technological frame. discussed as an interactionist concept of obduracy, also relates to embeddedness because during the building of a technological frame artifacts become embedded in a network of institutions and practices. Also, the development of the internal combustion engine, used above as an example of embeddedness, may also be described in terms of a technological trajectory in which certain solutions were chosen while others were excluded.

When it comes to our understanding of obduracy, then, the various disciplines architecture, history of planning, economics. history and sociology of technology offer similar or interconnected conceptual tools. The use of "paradigm"-related concepts is apparent in both STS and planning history; consider, for instance, the concepts of "technological frame" and "mental model" in STS and "professional worldviews" in the history of planning. Moreover, some attempts have already been made 10 apply concepts that were originally developed for the analysis of other technical systems or artifacts to the analysis of cities, town planning. or urban artifacts (cf. Gullberg and Kaijser"s City Building Regime approach, Aibar and Bijker's analysis of Barcelona using SCOT, and Latour's story about the subway tunnels in Paris).

Despite the fluidity of disciplines and paradigms that address obduracy in a conceptual manner, it would be wrong to gloss over all major distinctions. Approaches discussed under the heading of material obduracy, my first category, tend to neglect the social and cultural roots of obduracy that are crucial to the other three conceptions 
of obduracy. Authors who like Trefil. Vance, and Lynch highlight the material aspects of obduracy sometimes focus on intrinsic propertics of urban artifacts, materials or shapes as causes of obduracy, a view that is disputed by STS-scholars; after all, they emphasize the socially constructed character of all technology, which is why obduracy of technology can never be innate and why any explanation of obduracy that is exclusively based on material factors should be rejected.

The category of material obduracy involves a static conception of obduracy, but my three other categories - interactionist. relational and enduring - can be interpreted as different, though compatible constructirist conceptions of obduracy. If obduracy is mainly associated with dominant ways of thinking, we have to do with an interactionist conception of obduracy: Obduracy can be the result of interactions between various groups of actors. The interactions between the actors are structured and often constrained by the meanings and values they attribute to technologies. In contrast to interactionist conceptions, explanations of obduracy in terms of embeddedness and persistent traditions no longer take social groups as a starting point. Embeddedness involves a relational conception of obduracy: it can be explained by the interrelatedness of various, heterogeneous elements in a sociotechnical ensemble; obduracy may be the direct result of, for instance. the tight relations between the various elements. An explanation of obduracy in terms of persistent traditions, my fourth category, differs from the others because of its more enduring character-its focus on Ionger-term processes that are deeply rooted in culture at large and that depending on the specific tradition or pattern may vary only slightly. A clear difference with the category of dominant ways of thinking is its focus on collectively shared rules and valucs that transcend specific groups and local contexts. Whereas concepts in the category of dominant ways of thinking highlight the differences between social groups, a focus on persistent traditions reveals the similarities, what is shared among groups: no group or single actor can easily escape from influential and lasting traditions.

There are also substantial differences between the conceptual frameworks as such, even within STS. ${ }^{\text {1"2 }}$ The STS-approaches discussed - Actor Network Theory (ANT), the Large Technical Systems-approach (LTS) and Social Construction of Technology (SCOT) - originate in different theoretical traditions: ANT grew out of scmiotics, LTS is an offshoot of the history of technology and business history, while SCOT has roots in symbolic interactionism. Although all three approaches rely on the "seamless web" metaphor as a starting-point for research, ANT differs from the other approaches by not accepting a fundamental distinction between human and non-human actors. ANT-theorists embrace the "principle of generalized symmetry", which means that the same theoretical framework should be applied to the analysis of human and non-human actors. SCOT emphasizes the role of interactions between "relevant social groups" and the meanings they give to a certain technological artefact. The concept of "technological frame" was introduced to avoid social reductionism."

Furthermore, the wide range of different "units of analysis" and "research sites" of the various approaches deserves mention. Technological frames, scripts and mental models are related to artifacts or technical objects. momentum to technological systems, irreversibility and durability to actor-networks, path dependence to innovative activities in firms, permanence and adaptability to artifacts and 


\section{Chapter 2: Obduracy of Sociotechnology}

infrastructures in cities. How, then, are the four broad categories of conceptions of obduracy that I identified to be "Iranslated" into a useful apparatus for approaching the issue of obduracy in processes of urban sociotechnical change?

Table 2.3: Four conceptions of obduracy

\begin{tabular}{|c|c|c|c|c|}
\hline & $\begin{array}{l}\text { Material } \\
\text { obduracy }\end{array}$ & $\begin{array}{l}\text { Dominant ways } \\
\text { of thinking }\end{array}$ & Embeddedness & $\begin{array}{l}\text { Persistent } \\
\text { traditions }\end{array}$ \\
\hline $\begin{array}{l}\text { Explanatory } \\
\text { mechanisms }\end{array}$ & $\begin{array}{l}\text { Obduracy } \\
\text { explained by } \\
\text { intrinsic pluysical. } \\
\text { material and form } \\
\text { features }\end{array}$ & $\begin{array}{l}\text { Obduracy } \\
\text { explained by } \\
\text { constrained ways } \\
\text { of thinking }\end{array}$ & $\begin{array}{l}\text { Obduracy } \\
\text { explained by the } \\
\text { close } \\
\text { interconnectednes } \\
\text { sof social and } \\
\text { lechnical } \\
\text { elements }\end{array}$ & $\begin{array}{l}\text { Obduracy } \\
\text { explained by the } \\
\text { long-term } \\
\text { persistence of } \\
\text { traditions }\end{array}$ \\
\hline $\begin{array}{l}\text { Concepts and } \\
\text { metaphors }\end{array}$ & 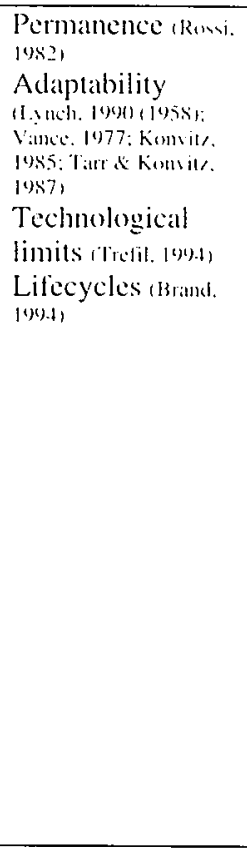 & 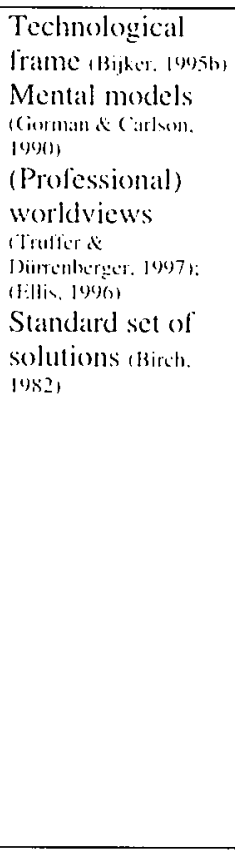 & 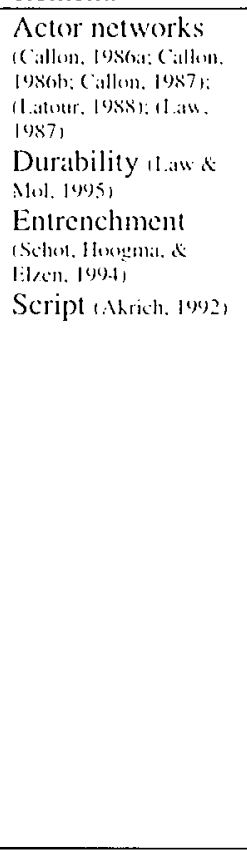 & 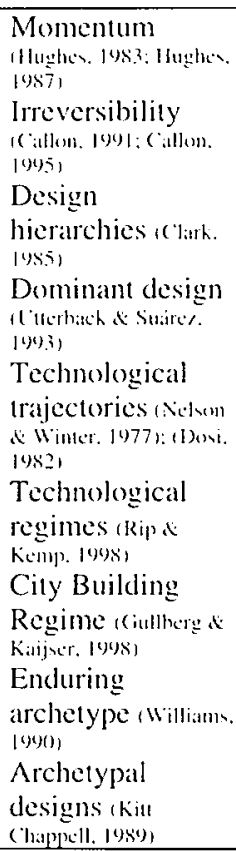 \\
\hline $\begin{array}{l}\text { Disciplinary } \\
\text { background } \\
\text { or intellectual } \\
\text { tradition }\end{array}$ & $\begin{array}{l}\text { (History of) } \\
\text { architecture. } \\
\text { Urban design } \\
\text { theory. Urban } \\
\text { history }\end{array}$ & $\begin{array}{l}\text { History and } \\
\text { sociology of } \\
\text { technology } \\
\text { (Social } \\
\text { Construction of } \\
\text { Technology). } \\
\text { History of } \\
\text { planning }\end{array}$ & $\begin{array}{l}\text { Actor-network } \\
\text { theory. Sociology } \\
\text { of imnovation }\end{array}$ & $\begin{array}{l}\text { History and } \\
\text { sociology of } \\
\text { technology. } \\
\text { Evolutionary } \\
\text { economics. Large } \\
\text { technical systems } \\
\text { approach }\end{array}$ \\
\hline $\begin{array}{l}\text { Type of } \\
\text { explanation }\end{array}$ & $\begin{array}{l}\text { Static conception } \\
\text { of obduracy }\end{array}$ & $\begin{array}{l}\text { Interactionist } \\
\text { conception of } \\
\text { obduracy }\end{array}$ & $\begin{array}{l}\text { Relational } \\
\text { conception of } \\
\text { obduracy }\end{array}$ & $\begin{array}{l}\text { Enduring } \\
\text { conception of } \\
\text { obduracy }\end{array}$ \\
\hline
\end{tabular}




\section{The analysis of obduracy in processes of urban sociotechnical change}

As indicated in the introduction, my interest in obduracy is mainly motivated by my concern for efforts that are aimed at reshaping (urban) technology. None of the concepts discussed in the previous sections is entirely appropriate for analyzing such efforts for three reasons: (1) most of the concepts are related to technological objects and are thus not specifically focused on the analysis of processes of sociotechnical change in the city; (2) most of the concepts address only a small aspect of the issue of obduracy, or provide only partial, a-symmetrical explanations; (3) most of the concepts discussed address the initial shaping of technology rather than its redesign in the context of urban renewal. Nevertheless, it would of course be a great mistake to reject these conceptions of obduracy altogether. At least some of the concepts discussed have already proven their usefulness for analyzing processes of urban redesign. The fact that other concepts have not yet been applied to the city does not mean that it is impossible or unproductive to do so. By integrating the most valuable elements of each of the four conceptions, I focus my argument on those elements that I find particularly useful for the analysis of obduracy in cities:

- Material obduracy highlights the material aspects of obduracy. Technology is not merely "thought stuff", but there is an obdurate material reality that plays a crucial role in processes of urban change. It would be wrong, however, to view obduracy as an intrinsic property of technology or to explain obduracy by referring to material factors alone. I will use a 'symmetrical' approach in which it is not $a$ priori and independent of context clear whether material or social factors can explain the obduracy of sociotechnology.

- Dominant ways of thinking stresses the role of obduracy in design processes. Studying obduracy in urban redesign processes involves the identification of the actors involved in local town planning processes and 'unbuilding' activities as well as the analysis of their, potentially opposite, ways of thinking. In this study, I will primarily focus on the constraining effects of these ways of thinking in terms of technological frames and inclusion. This concept seems the most appropriate because, in contrast to the other conceptions in this category, technological frames are also applicable to other social groups than engineers, such as citizens. Moreover, this concept is sufficiently broad to encompass the heterogeneity of elements that are involved in urban sociotechnical redesign.

- Embeddedness emphasizes the interrelatedness of elements in an urban sociotechnical ensemble. This notion nicely captures the heterogeneous character of cities: streets, buildings, distribution networks, development plans, politicians and pressure groups together constitute the large, complex sociotechnical ensemble that the city is. In cities. infrastructure, laws and regulations, traffic schemes, usage, urban policies and town planning structures are closely interconnected. In specific circumstances, this can result in the obduracy of either individual elements or the ensemble as a whole.

- A focus on persistent traditions highlights how culturally embedded and collective traditions that persist over a longer period of time and transcend local contexts contribute to the obduracy of urban structures. In cities, long-term, long-standing architectural or town planning traditions play a major role, for instance, in the 
constitution of the obduracy or malleability of its parts.

Apart from this theoretical exploration of conceptions of obduracy in (urban) sociotechnical change, a confrontation between these theoretical conceptions and my empirical case studies is needed in order to refine the conceptions and gain insight into the tensions between obduracy and change in urbain redesign projects, and to elaborate on the question how STS can contribute to studying cities. In the following chapters. I will analyze case studies of the tensions between obduracy and change in three ongoing urban redesign projects in the Netherlands: the redesign of Hoog Catharijne as part of the Utrecht City Project, the highway reconstruction in Maastricht, and the spatial renewal of the Bijlmermeer. I rely on the three constructivist conceptions of obduracy discussed in this chapter, as a way to unfold the explanatory power and specificity of these conceptions in singular case studies. Therefore, each case is analyzed using only one conception of obduracy. Finally, in Chapter 6. I propose a more integrative approach in which the different conceptions of obduracy will complement each other.

My case studies are based on interviews with key actors and the analysis of a variety of written sources. Two criteria were relevant for my selection of the key actors. First, interviewees should have been directly involved in activities to unbuild or preserve urban space in the redesign project under study. Second, the interviewees should have been involved in various stages of the (re)design process. In this way. a host of actors came in view: residents of town districts who made their own proposals for the redesign of the area, members of citizens' action groups who protested against specific redesign solutions, city employees with town planning and infrastructure departments, politicians, engineers, town planners and architects involved in the making of the original plans and new design proposals, and so forth. It was possible to identify these actors in project documentation, newspaper articles, lists of participants of public hearings, and other sources. Moreover, I also relied on the "snowball method," which means that after each interview I asked the interviewee who else should be interviewed."'In this way, the actors' own identification of relevant actors was also taken into consideration as an important factor. The interviews were taperecorded (see the Bibliography for a list of interviewees).

Written source materials were obtained from various archives: municipal archives, archives of the project offices, personal archives of key actors, and newspaper archives. I tried to cover a wide range of different sources: meetings' minutes, town planning proposals, reports of public hearings, local and national newspaper articles, pictures, maps, pamphlets and brochures, and personal and official correspondence. Since my focus was on the process of 'unbuilding' urban structures rather than on the initial conception and building of the three projects, I concentrated the gathering of primary source material on the period when 'unbuilding activities' started. Where extensive research was already available, as is true regarding the decision processes that resulted in the building of the Bijlmermeer and Hoog Catharijne, I relied on these secondary sources. In the Hoog Catharijne case, I focused on the period between 1986 and 1997, after the start of the Utrecht City Project. My analysis of the efforts at reconstructing the highway through Maastricht covered the period from 1974 to 1998; whereas my study of the renewal of the Bijlmermeer 
addressed the period from 1974 to 1998, with an emphasis on the period since 1986 when the demolition plans became definitive. Because of the recent date of these unbuilding processes, the sources I studied were not yet well archived in most cases. See the Bibliography for a list of archives.

In Chapter 3. I will analyze the attempts at redesigning Hoog Catharijne. I focus on the role of dominant ways of thinking in the constitution of obduracy. I describe the emergence of two rival technological frames in the redesign process. As a result of the rigidity of these frames, some elements of Hoog Catharijne appeared to be more difficult to adapt than others and a deadlock in the planning process occurred. How did the actors involved eventually succeed in abandoning the two technological frames and changing the stabilized town planning design of Hoog Catharijne? In my analysis. I foreground the building-up and breaking-down of technological frames and the degrees of inclusion of the actors in these frames.

Chapter 4 is concerned with the attempts to reconstruct the highway that cuts through the city of Maastricht. In this chapter, I will pay particular attention to the embeddedness of heterogeneous sociotechnical elements. The highway's design became contested when car traffic increased, regulations and norms regarding noise and traffic safety changed and local, regional and national infrastructure policies were altered. Already in the late fifties the idea of a tunnel was put forward as a solution to the traffic, safety and liveability problems that were caused by the highway's design. Why did the existing structures of the highway through Maastricht maintain their obduracy despite all efforts? I will focus my analysis on specific types of embeddedness: in traffic schemes, in town planning structures, in local or governmental policies and in legal norms and regulations. I argue that, apart from the embeddedness of existing physical structures, specific design solutions (such as the tunnel) that are not yet implemented can become embedded in policies and citizens' strategies, thereby acquiring obduracy.

Chapter 5 is about the spatial renewal of the Bijlmermeer. In this chapter, the persistence of traditions in urban sociotechnical development is my focus. I propose a cultural interpretation of persistent traditions in urban sociotechnical developments in which I highlight how culturally embedded, long-term (town planning) traditions keep influencing design choices thereby contributing to the obduracy of urban structures. I will argue that the specific features of the modernist town planning concept and certain characteristics of the utopian tradition in which this town plan is embedded kept influencing the developments and choices in the spatial renewal process of the Bijlmermeer until the late 1990s, long after the initial circunstances under which the original town plan had come into existence had vanished. 


\section{Obduracy and Dominant Ways of Thinking: Changing Utrecht's Down Town Shopping Area (Hoog Catharijne)}

\section{Introduction'}

Hoog Catharijne, a large-scale urban redesign project in the Dutch city of Utrecht, was planned in the 1960s. The project radically altered the look of the downtown district, some parts of which go back to the medieval period. The plan was meant to revitalize the city's economy and comprised a modern shopping mall, apartment buildings, offices, a new railway station and bus station, and a complete reconstruction of the area's infrastructure. Despite the plan's ambitious character, many residents of Utrecht regretted Hoog Catharijne even before the complex was officially opened (see Figure 3.1).' The project's overall concept was generally perceived as rigid and outdated, its architecture as outright ugly. In 1970, a group of concerned residents founded an activist committee; among other things, it organized a protest rally attended by some four thousand people on the day of the official opening of the complex in June 1973. Because of its design and sheer size, Hoog Catharijne soon became a pre-eminent symbol of capitalism in the public mind. As the author of a journal article on the day before the opening of Hoog Catharijne pointed out:

New and very recent is the objection that Hoog Catharijne is a symbol of a society that is directed at consumption and production. ... There is indeed a growing notion that the continuous desire for more. better, bigger and more beautiful leads us to the abyss that is so realistically described in the Club of Rome's report.

Moreover, critics argued, Hoog Catharijne lacked the social function of meeting place inner cities should have. Many saw its buildings as overly functionalist and their dismal architectural quality was hardly disputed."

When the complex was close to completion, many felt that it already belonged to a bygone era, while the inflexibility of the overall design left little room for future adaptation to newer views:

It is observed that while views about the city's central district are changing. they cannot be realized anymore because of Hoog Catharijne's rigidity. Resistance and 
irritation are on the rise. and Utrecht's residents increasingly consider Bredero" a threat to local living circumstances rather than viewing him as the builder of the city's new future."

There was a widespread feeling among critics at the time of Hoog Catharijne's completion that the project's design would not allow the incorporation of new views about city renewal at any point in the future. They emphasized that the sheer size of the complex left no opportunities for alternative projects to leave their mark on the downtown district. Moreover, the complex was designed to expand; it had a built-in tendency to spread and this would further erode the city's liveability. One commentator referred to it as a "lump" and a "tumor" that was growing every day. In the newspapers Hoog Catharijne was portrayed as "immovable", "a dead moloch". "not very flexible". "a matssive concrete lump", and "a concrete tumor".

The poor image of Hoog Catharijne was often tied to its major building material, concrete." Seeing mass and immobility as intrinsic properties of concrete, people seemed to blame the material for the obdurate character of the complex." Bredero, the construction company, was held responsible for Hoog Catharijne's disappointing appearance, and frequently cynical slogans like "Bredero Beton" (Bredero concrete) or "Jantje Beton", as a nickname for the builder"s director Jan de Vries, could be heard in those days."

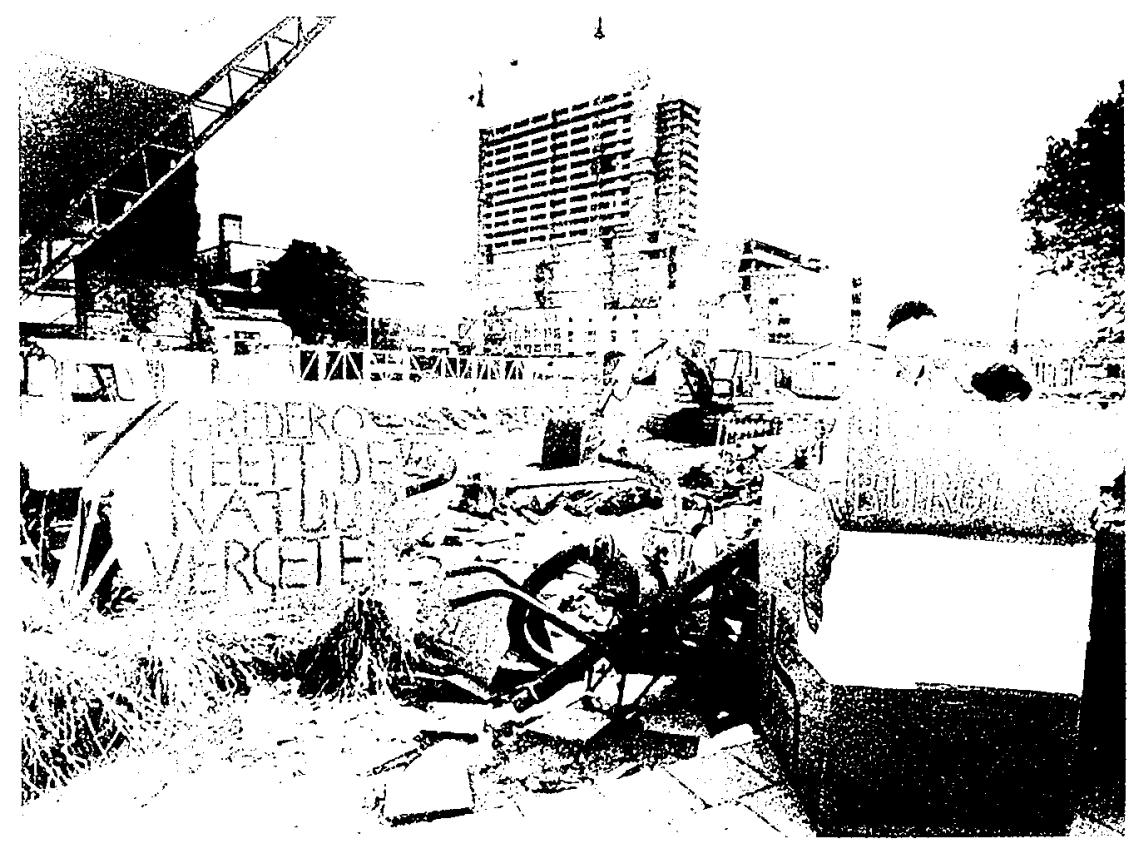

Figure 3.1: Protests against Hoog Catharijne (1973)

"Bredero has forgoten nature". "Concrete: better?" and "Citizen of Utrecht. Concrete" Source: Het Utrechts Archief (1) Fotopersbureat is Sticht 
Others, however. espoused a different opinion on Hoog Catharijne's design. One of Hoog Catharijne's architects K.F.G. Spruit, for example. emphasized that it was certainly possible to change existing city centers and Hoog Catharijne in particular. claiming that its newer sections were designed differently and that a variety of materials was used." Spruit expressed his astonishment about the protests and suggested they were not so much aimed at the use of concrete as a construction material but at "Hoog Catharijne as a large-scale company." Spruit. designer of a large insurance company's major office building (AMEV). compares the public reactions to his building with the controversy about Hoog Catharijne:

\section{Consider the example of the AMEV-building. Is anyone talking about AMEV- concrete". No, but they are lalking about "Hoog Catharijne-concrete" or "Bredero- concrete". And do you realize that the very same material was used in both cases!"}

This exclusive focus on the material as a decisive or intrinsic property of a structure's obduracy provides a good example of "material obduracy" (see Chapter 2). Views like those of Spruit suggest that actors may have divergent positions on the obduracy of particular urban structures, even if a huge project like Hoog Catherijne is involved.

Meanwhile, during the 1970)s the residents of Utrecht saw no other possibility than to take their city's changed inner reality for granted in all its concrete ugliness. Roughly a decade later, in the mid-1980s, several negative effects of Plan Hoog Catharijne came to the fore, though. As a consequence. the city leadership initiated a new project to upgrade Hoog Catharijne: the Utrecht City Project (UCP). The ideats about city planning. infrastructure. traffic circulation and social safety had changed profoundly in the intervening years. How did these new ideas as reflected in the UCP affect the obdurate structures of Hoog Catharijne? Why did the project's design maintain its obduracy despite all the efforts to rebuild it? How did the actors involved eventually, if only temporarily, succeed in changing the seemingly unassailable presence of Hoog Catharijne?

In this chapter I analyze the role of obduracy in plans about changing Hoog Catharijne by relying on the concept of "technological frame" and the notions of "closed-in" and "closed-out" obduracy. To describe the alternations of obduracy and malleability in this unbuilding process, I focus on the building-up and breaking-down of technological frames. More specifically, I will pay attention to the capacity of outsiders to change dominant technological frames - a recurring theme in STS." First. I dwell a little longer on the conception and building of Plan Hoog Catharijne. Next. I focus on the effort to radically transform the Hoog Catharijne area in the years between 1988 and 1995, and I argue that two technological frames dominated this effort. Finally, I demonstrate how these technological frames eventually changed after 1995, partly as a result of the efforts of an outsider, a new town planning supervisor. 


\section{Cast in concrete: Plan Hoog Catharijne}

The Plan Hoog Catharijne was developed by development company Empeo, a subsidiary company of the large construction company Bredero. The plan was generally viewed as a solution for many of the problems Utrecht was facing in those days." Because of a housing shortage, the city needed more space for its growing population." After World War Two the city government, motivated by progressive ideals, articulated ambitious plans for expanding and improving the city: Utrecht had to become larger and more prosperous. One of the concrete goals involved the strengthening of the central economic role of the city in the region."

To achieve this end. the city board put much effort in enhancing the accessibility of the downtown district. The increasing number of automobiles had created congestion, a problem the city already acknowledged in the 1950s. Many felt that the city's infrastructure had to be adapted to accommodate this increase of cars." The city government invited Professor M.E. Feuchtinger. a German traffic circulation expert, to design a new traffic circulation plan for Utrecht. In 1958, Feuchtinger proposed to construct a peripheral road around the city center. This meant that some of the characteristic canals would have to be paved over. In the late 1950s, Utrecht, like many other Dutch cities, was challenged by the need for huge urban reconstruction projects that involved the building of new peripheral roads and the demolition of urban neighborhoods or parts thereof." It was mostly the increased traffic density that served as a legitimation for filling in canals and rearranging the existing architecture of the city."

Feuchtinger's city renewal proposals would radically change downtown Utrecht and. not surprisingly, they met with opposition. The city council decided that the town planning aspects of Plan Feuchtinger had to be investigated first and it invited architect J.A. Kuiper to carry out this research. Since Utrecht's leadership foresaw a substantial expansion of the service sector it wanted to double the amount of office space." Becautse of the city's population growth, more retail space was needed as well. The main question in the ensuing debates involved the location of the new office buildings, wholesale businesses and shopping districts. Kuiper presented his plan in 1962. He argued for a deconcentration of the downtown activities over a larger part of the city. Kuiper and other proponents of deconcentration held that unsolvable traffic and parking problems would be caused by locating most of the business and commercial activity in the downtown area. Kuiper's reasoning, however, failed to convince the city leadership.":

At the same time, the NS, the Dutch National Railway Company, was increasingly struggling with a lack of space in downtown Utrecht, the location of its main offices as well as of the city's Central Station, the busiest and most centrally located railway station of the Netherlands. In addition to building a larger railway station, the NS wanted to increase the amount of parking space near the station." At the request of the NS, Empeo studied the possibilities of building parking garages near the railway station. At first, only the area directly surrounding the railway station was taken into account, but at a later stage this study gave rise to a plan to reconstruct the whole station area. On 20 March 1962, the city leadership and representatives of the NS, Empeo and building company Bredero discussed a proposal for an integrated 
reconstruction of the railway station area and its immediate vicinity. The NS and the city board representatives reacted enthusiastically." They gave Empeo six months to prepare an extensive redesign plan.

Empeo put together a multidisciplinary team consisting of a town planning consultant, a social scientist, a traffic expert. a technician and a construction manager. They developed a plan in consultation with experts of the NS and the city. The first Plan Hoog Catharijne was published in October 1962. Based on the results of the investigations of this team and referring to broader discussions concerning the location of business activities in relation to downtown districts, Empeo proposed a concentration of business and commercial activities. In its view, decentralization would have huge disadvantages for shops and offices that had to move to the city's outskirts. Moreover, this would produce, in effect, more car traffic. Apart from that, Empeo claimed that Plan Hoog Catharijne harmonized well in many ways with the plans of Feuchtinger and Kuiper."

Thus the original Plan Hoog Catharijne of 1962 consisted of an all-out redesign of Utrecht's railway station district. The plan covered the whole area in the immediate vicinity of Central Station. The main argument for choosing this location was tied to its central role as a national railway junction, while it served as a transportation crossroads at a local and regional level as well. Furthermore, it was argued that this area could be elegantly connected to the pedestrian routes of the old, inner city of Utrecht. A radical reconstruction of the entire Central Station area would also provide ample opportunities for solving the city's traffic and parking problems."

For this reason, the infrastructure of the area had to be transformed drastically and it would include office buildings, apartment buildings, parking lots, a new railway station, a concert hall, a bus station and the largest indoor shopping mall of the country. The design of Hoog Catharijne was based on a strict separation of traffic flows. The connection between the station area and the old part of the inner city was to be established by the construction of separate pedestrian passages (see Figure 3.2). Because the total space for the various forms of mobility-pedestrians, cyclists, cars and buses-had to be augmented, various functions were designed at separate levels." The pedestrian level, comprising the indoor mall and Central Station, was planned at 5.5 meters above street level. "The entrances of shops and offices would be situated at this raised pedestrian level, while street level was reserved for parking, service roads, the bus station, showrooms and so on. "The elevated level not only provided a solution for the barriers posed by the Catharijne canal and the railway tracks, it also created a shorter pedestrian connection between the railway station and the old part of the inner city. This functionalist design allowed people to shop without being disturbed by car traffic or other nuisances.'

Calculations about potential risks were built into the design of Hoog Catharijne The first plans included broad open-air passages for pedestrians rather than indoor ones. The initial idea was to construct open pedestrian squares at a raised level (see Figure 3.2). However, this plan was abandoned for safety reasons after wind-tunnel tests had proved it to be a dangerous construction. Because of its openness, and the unpredictability of wind gusts in high-rise areas, people might be "blown away":

To be sure, commercial motives also in part determined the ultimate plan: Hoog Catharijne's design more or less compelled pedestrians to walk through the Hoog 
Catharijne passages lined by shops because this was the easiest and most comfortable route between the railway station and the city center. This arrangement was expected to turn train passengers into potential customers. The estimated number of pedestrians in Hoog Catharijne was based on the expectation that people would choose the shortest route, which meant that sections of the mall were likely to become as busy as the most crowded shopping street of Amsterdam. As a result, it would be very attractive for retailers to start their business in Hoog Catharijne.

In this way, a preference for functionalist town plamning and traffic regulation. and calculations about risks and commercial potential were built into $\mathrm{Hoog}$ Catharijne's design. The plan was almost unanimously accepted by the city council and in February of 1964 the city signed a contract with development company Empeo. A new company. in which the city did not participate. was founded for the realization and exploitation of the plan: Hoog Catharijne. Ltd. The contract basically states that the city leases the area to Hoog Catharijne, Lid. until the year 2070).

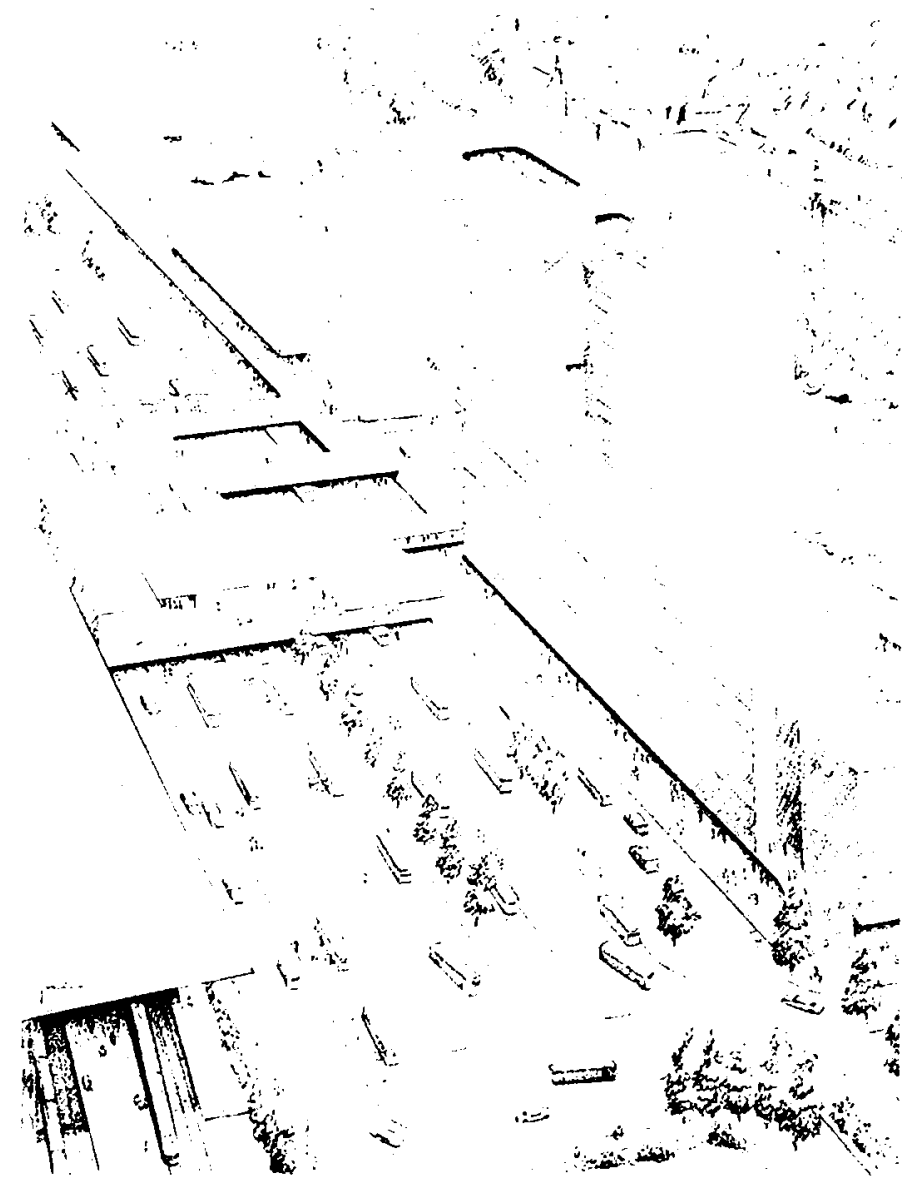

Figure 3.2: Drawing Plan Hoog Catharijne (1963)

Source: Het Utrechts Archicf 
A few obstacles had to be dealt with. however, before and during the building process. The consequence of situating the new town plan in the station area was that the existing houses near Central Station had to be demolished. These demolition plans were very much in line with the trend to replace functions and properties that were considered unprofitable, such as houses with low rental values or small shops and catés, by more profitable venues. Yet. evidently. the residents whose houses were going to be sacrificed were not all happy about it and they voiced their protests against the plan. Another problem involved the site of the nearby convention center of the Royal Dutch Industries Fair that had to be moved for the implementation of Plan Hoog Catharijne. Although the Industries Fair was already coping with a lack of space in 1963, it did not want to move to the west side of Central Station. Empeo had great difficulty developing a plan in which the building of the Industries Fair could remain in place. Finally, in 1968. the Industries Fair decided to move to a nearby location.

The debates about some of the canals that were needed as roads lingered on for close to a decade. In 1964. Utrecht's medieval canals provisionally acquired the status of national monument. "As a consequence, the canals could not be tampered with without permission from the Dutch government. Nevertheless, in May 1964. the city board proposed to fill in the Catharijne canal, a plan that readily passed the city council as well. In order to win the national government's consent. a working group consisting of representatives from the ministries, the region and the city was founded. It concluded that filling in the Catharijne canal was necessary for the realization of the Plan Hoog Catharijne, suggesting that Feuchtinger's plan to convert some of the canals into roads had become so much built into the subsequent plans that it was no longer sensible to avoid it. Finally a compromise was reached and Minister Marga Klompé granted permission to fill in part of the Catharijne canal in January 1968.

In 1969 the first new office buildings, parking garages and one of the raised pedestrian passages of Hoog Catharijne were completed. Although the building activities would continue until the late 1980)s, the official opening of Hoog Catharijne took place on 23 September 1973 (see Figure 3.3 for an overview of the area).

Hoog Catharijne's town planning design thus became gradually embedded in Utrecht's urban structures. Many have indicated that Hoog Catharijne gave a boost to the local economy, but in the 1980s some negative consequences came to the fore as well. Drug addicts, homeless people and psychiatric patients populated the indoor mall in ever-larger numbers, whereas the dark service alleys and ground level parking areas grew into a meeting place for drug dealers and addicts.

In 1982. the Hoog Catharijne shopping mall was bought by the ABP. a large Dutch pension fund. The ABP had plans to revitalize the property after many stores had seen their profits decline and some of them went bankrupt: the areal's other large property owners, the NS Railway Company and the Industries Fair, were also making plans for improvements. In 1987. the newspapers reported that the city initiated the development of a new plan for the Central Station / Hoog Catharijne district. It wanted to design a completely new town plan for the area in cooperation with the NS, the Industries Fair and the ABP." This public-private partnership was in charge of the Utrecht City Project," and in June 1988, the partners signed a "declaration of intent" to develop the new plan."

One of the crucial design characteristics of Plan Hoog Catharijne. the strict 
separation of flows of traffic, had served as a basic concept in all planning proposals that were made for the area. After 1988, however, several attempts were made to reverse this concept. These efforts will be discussed in the remainder of this chapter.

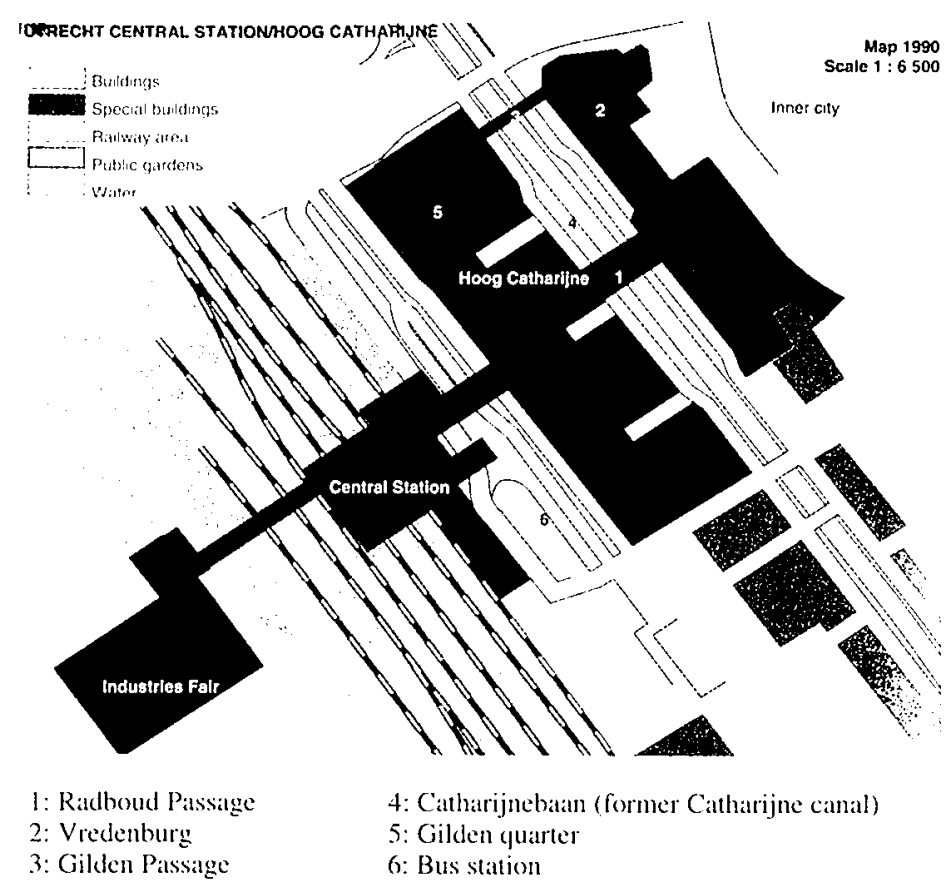

Figure 3.3: Overview of the Hoog Catharijne area

Source: Adapted from De Grote Bosatlas (1) (1998: 24 B)

\section{Building up technological frames}

Bijker proposes to distinguish three "configurations", based on the different roles of technological frames in the interactions between actors and the processes of sociotechnical change and stabilization that are expected to take place. In the first configuration, there is no clearly identifiable dominant technological frame, nor is there a single dominant social group. In the absence of overriding vested interests in the interaction process, radical alternatives are likely to emerge. A redefinition of the problem usually functions as the closure mechanism in such a configuration. This means that social groups try to persuade other social groups of their view by redefining the problem in such a way that it becomes attractive for this group to support the sociotechnical ensemble.

In the second configuration, one technological frame dominates the interactions of various actors. In such cases, Bijker finds it useful to make a distinction between actors with a high inclusion and those with a low inclusion in this technological frame. The interactions of actors with a high inclusion are very much structured by the technological frame involved, which usually results in conservative alternatives on 
their part. Actors with a low inclusion are less "guided" by the technological frame, and, ats a result, they are more likely to come up with more radical variations.

The third configuration is characterized by the presence of two (or more) equally dominant technological frames, as well as two or more dominant social groups. In this configuration. arguments that play a crucial role in one frame are mostly seen as totally irrelevant in the other frames. In such cases, rhetoric plays an important role in the stabilization process. Frequently, the result is a situation in which "no one wins al total victory". An "amalgamation of vested interests" takes place that results in moderate modifications at best, because. after all, the proposed innovations need to be acceptable to all groups and have to fit all the dominant technological frames involved.

From the outset the discussions about the new town plan in Utrecht in the late 1980) were dominated by a distinction between two town planning models: the "ground floor" model versus the "raised level" model. During the discussions about these models two dominant technological frames emerged: one based on the ground floor philosophy, advocated by the city, and another taking the raised level structure as its point of departure, strongly preferred by the ABP (see Table 3.1 for a summary of the elements of these two technological frames). This situation of two dominant technological frames corresponds best with Bijker's third configuration. What were the basic vicws advanced by the two parties?

The Director of the Town Planning Office of the city of Utrecht formulated the central problem as follows:

The basic isste of the two models presented here involves the question whether the rigid separation between having pedestrians on an elevated level and the other flows of traftic on the ground floor level, that was favored in the 1960). can be reversed by linking up pedestrian traffic [more directly] with the ground thoor level."

This "ground floor" model stressed the importance of the accessibility of public buildings - including Central Station - at the ground floor level as a way to better integrate them into the immediate surroundings. Morcover, the issue of public safety also played a prominent role. Especially at night the dark and deserted parking spaces and service alleys on the ground floor had attracted criminal activity; it was argued that an upgrading of this level, in part by encouraging the presence of more pedestrians, would raise public safety at this level accordingly. Therefore, this model emphasized the significance of adding alternative walking routes. It should still be possible to walk through Hoog Catharijne via the raised level, but alternative routes had to be added that contributed to a better integration of the ground floor level in the overall structure.

The ground floor model followed ideas on urban design that gained prominence in the late 1960s. During that time, authors who wrote about town planning began to highlight the "social city" - the city as meeting place. ${ }^{4 x}$ The American Jane Jacobs is often portrayed as the most important proponent of this tradition." In her book The Death and Life of Great American Cities. The Failure of Town Planning (1961), Jacobs harshly criticized the contemporary town planning practices in American cities. especially condemning the megalomania and totalitarianism of the large-scale urban 
interventions proposed by architects like Le Corbusier or project developers such as Robert Moses. Rather than large-scale, monotonous. functionalist town planning. she emphasized the importance of small-sized building. diversity. (social) salfety, and concentration. In her book. Jacobs describes the city from the perspective of the neighborhood resident, the pedestrian. to whom the street and the sidewalk are indispensable symbols of the city als a meeting place. She argued that the street be reestablished as a major urban public space." Jacobs"s views found resonance with many in both Europe (including the Netherlands") and the United States. In line with the activist spirit of the late 1960s and carly 1970)s. local action groups and neighborhood committees were established in response to undemocratic decision processes and large-scale urban interventions. Proponents of the ground floor model were in part inspired by this new mode of thinking about city life.

By contrast, the second model, the so-called "raised level" model. basically held on to the existing philosophy of separating flows of traffic. The pedestrian passage that cuts through Hoog Catharijne should continue to be the main route, proponents argued, but it had to be improved. In their view, the new design should enhance the raised level structure by expanding it." The creation of new pedestrian routes on the ground floor level, as the other model proposed, would decrease the amount of pedestrians at the raised level, and this was seen as a negative factor in public safety at the raised level."

The two models were presented in a report, called "The Utrecht City Project: Perspectives for the Future" ("Perspectives" report). Although it emphasized that the two models represented two extremes, the ensuing debates made it seem as if a choice had to be made between them, and gradually parties were formed that defended either one of the two models.

The city expressed a preference for the ground floor model, arguing that the main problem consisted of poor public safety and that this was triggered by Hoog Catharijne's originally flawed design. Because of the elevated pedestrian passages, the ground floor level - dominated by motorized traffic - had little value as a public space. The city representatives stressed the significance of the street as a public space and the role of the city as a meeting place. "The quality of the ground floor level as a public space could be improved by introducing additional social and commercial functions at that level, such as shops and apartments.

According to the ABP, the increasing number of drug addicts and homeless people in Hoog Catherijne caused great inconvenience, fostered a negative image of the shopping mall, and therefore threatened its profitability. The ABP wanted to control this problem by installing cameras, refurbishing the mall's interior design ${ }^{57}$ and concentrating pedestrians on one level - in this case the raised level - to guarantec maximal social control. Although the ABP was interested in improving the safety of the area. from a business point of view it argued against an effort to integrate the ground floor level. An exclusive focus on the ground floor level presented obvious risks for the functioning of the mall, and thus for the profitability of its shops that all had their entrance at the elevated level "; therefore, this level ought to be preserved as the main route. Radical changes in Hoog Catherijne's basic design were uncalled for, because the mall - despite some of its obvious problems - functioned quite well as a comfortable connection between the inner city and Central Station. A former ABP 
manager suggested that the separation of traffic flows was "one of the greatest achievements" of the original design."

The main problem for the NS was that, in the 1970)s, Hoog Catherijne had swallowed Central Station, which had thus become invisible and lost its identity. The NS's main concern in light of the City Project was to turn Central Station into a visible urban entity once again." This wish complied with the trend of increasing importance attached to the architecture of railway stations in the Netherlands since the 1980)s. Station architecture in the 1970s was characterized by austere. standard buildings, whereas since the early 1980s, the NS aimed at more "clear, convincing, recognizable" stations." In this respect. the NS saw Hoog Catharijne as a major obstacle in reestablishing a direct link to the old part of the inner city. In 1989, the NS was not convinced by either of the two models. The recognizability of the railway station remained a problem in both models, the NS felt, but holding on to and expanding the raised floor model would be the worst solution."

The Industries Fair had relocated to the west side of Central Station and Hoog Catharijne in the late sixties. Like the NS, it considered Hoog Catharijne a barrier that made it difficult to visitors of the Fair to reach the inner city - with its many cafés and restaurants - by foot. Thus, the main interest of the Industries Fair was to establish a comfortable connection between the inner city, Central Station and its own premises." The raised floor model comprised a new, extended pedestrian passage that significantly improved the connection between the Fair's grounds. Hoog Catharijne and the old part of the inner city. Not surprisingly. then. the management of the Industries Fair viewed this model as the better solution."

Clearly, the Perspectives report did not lead to a consensus among those who had major stakes in it. On the contrary, it pitted the various parties against each other. with the ABP and the Industries Fair opting for a plan based on the elevated model and the city and the NS strongly in favor of the ground floor model.

In this way, two technological frames were configured in the discussions on how to renew Hoog Catharijne. In the following section I will analyze how, exactly. the ground floor frame and the raised level frame structured the interactions between the actors involved in the planning process and how that resulted in a situation in which change in the established situation became increasingly difficult to accomplish. Arguments that played a role in the ground floor frame were not considered to be important in the raised level frame. The fact that actors were thinking and acting so much in terms of their own technological frame made it well nigh impossible to bring about any change at all, thus contributing to the obduracy of Hoog Catharijne. 
Table 3.1: Ground floor frame versus raised level frame

\begin{tabular}{|c|c|c|}
\hline $\begin{array}{l}\text { Elements of 'Technological } \\
\text { Frames }\end{array}$ & $\begin{array}{l}\text { Ground floor frame } \\
\text { (City) }\end{array}$ & $\begin{array}{l}\text { Raised level frame } \\
(A B P)\end{array}$ \\
\hline Goals & $\begin{array}{l}\text { Improving the cuality and } \\
\text { livability of the ground floor }\end{array}$ & $\begin{array}{l}\text { Strengthening and improving } \\
\text { (the profitability of ) the raised } \\
\text { level }\end{array}$ \\
\hline Key problems & $\begin{array}{l}\text { The poor archilectural guality } \\
\text { and limited public salfety of } \\
\text { street level }\end{array}$ & $\begin{array}{l}\text { The decreased economic } \\
\text { profitability of the raised } \\
\text { level, the poor image of the } \\
\text { raised level }\end{array}$ \\
\hline $\begin{array}{l}\text { Problem-solving } \\
\text { strategies/designs }\end{array}$ & $\begin{array}{l}\text { Creating new pedestrian axes } \\
\text { on the ground floor. } \\
\text { demolishing parts of the } \\
\text { raised level, adding functions } \\
\text { like stores and apartments to } \\
\text { the ground floor, improving } \\
\text { morphological cohesion } \\
\text { between Hoog Catharijne and } \\
\text { inner city }\end{array}$ & $\begin{array}{l}\text { Creating a circular route at the } \\
\text { raised level, broadening the } \\
\text { rased passages and adding } \\
\text { shops along them }\end{array}$ \\
\hline Current theories and models & $\begin{array}{l}\text { Compact City model } \\
\text { (governmental policy } \\
\text { guideline) }\end{array}$ & $\begin{array}{l}\text { Business economics, studies } \\
\text { of consumer behavior }\end{array}$ \\
\hline Design principles & $\begin{array}{l}\text { Mixing traflic types, street as } \\
\text { public space (accessible to } \\
\text { pedestrians and cyclists) }\end{array}$ & $\begin{array}{l}\text { Preserve vertical segregation } \\
\text { of tralfic types }\end{array}$ \\
\hline $\begin{array}{l}\text { Requirements to be met by } \\
\text { problem solutions }\end{array}$ & $\begin{array}{l}\text { Improvement of liveability, } \\
\text { governmental guidelines and } \\
\text { policy aims should be met }\end{array}$ & Profits may not decrease \\
\hline
\end{tabular}

\section{Two types of obduracy}

As suggested above, two technological frames structured the controversy in which the city, the ABP, the NS and the Industries Fair were the key players. I will describe the role of these frames in relation to two types of obduracy: closed-in obduracy and closed-out obduracy." Closed-in obduracy refers to actors with a high inclusion in a particular technological frame. Because of their high inclusion, these actors think and interact very much in terms of this technological frame, and they are unable to conceive of alternatives outside this frame. This results in a limiting of the available redesign options to mere variations on the existing schemes. Closed-out obduracy refers to actors with a low inclusion in a technological frame. These actors see little or no opportunities for variation within the frame, which is why they are prone to adopt a "take it or leave it" approach, and this generally triggers the formulation of radically new alternatives.

\section{Closed-in obduracy}

After the Perspectives report was published, for a long time the redesign options were limited to versions of either the ground floor model or the raised floor model (see Table 3.2 for an overview of the main UCP plans that were made between 1989 and $1997^{\text {th }}$ ). In 1989, it was hoped that by investigating the traffic aspects, a choice could be made between these two urban planning models." This study resulted in the so- 
called Interim report." Apart from an investigation of the traffic aspects, the aim of this report was to adapt the plans to incorporate demands and regulations put forward by the national government. In the early 1990s, governmental policies on zoning in urban areas encouraged the concentration of employment near junctions of public transportation. Moreover, these policies recommended the "compact city model," which implied that urbanization had to be concentrated in areas situated relatively close to city centers. Use of public transportation had to be stimulated and car usage had to be decreased. Governmental policies formed an important element in the ground floor frame and the city wanted to be the UCP plans in line with these policies, partly because this would improve its chance to obtain substantial governmental subsidies to support the project. Statistics and prognoses played a prominent role in the city's effort to justify the new plans that were based on variants of the ground floor model. The city's strategy to link it up with governmental policies and subsidies proved to be a powerful tool in stabilizing it.

Table 3.2: Official UCP plans between 1989 and 1997

\begin{tabular}{|l|l|}
\hline Plans & Published in \\
\hline Perspectives repont & February 1989 \\
\hline Interim report & November 1989 \\
\hline Project plan & June 1991 \\
\hline UCP Master plan & May 1993 \\
\hline Spatial-functional concept & June 1995 \\
\hline Preliminary town plan & February 1997 \\
\hline Definitive town plan & October 1997 \\
\hline
\end{tabular}

The Interim report presented statistics to support the potential strength of the UCP area as a top location for service industries: many companies expressed at preference for the city center of Utrecht as business location. On this basis it was predicted that the number of jobs in Utrecht's downtown district would go up. Given the governmental policies aimed at stimulating the use of public transport and decreasing car usage, an increase of the passenger flow in Central Station was projected. Assuming that Hoog Catharijne would not be able to absorb this increase, it would be necessary to add alternative pedestrian routes; the Interim report proposed such a new pedestrian route at the street level between the inner city and Central Station. This proposal was explicitly based on "a variant of the ground floor model"."

After the Interim report was discussed in public hearings and in municipal commissions, it was formally accepted on 13 December 1989 as a guideline for the town plans that were to follow in its wake." This adoption played a crucial role in stabilizing the ground floor model as the single basis for the future UCP plans. Even though the raised floor model was thus more or less abandoned, the ABP still had severe doubts about this choice."

In 1990, the city took the initiative to establish the "UCP Atelier", consisting of a group of town planners. It developed a proposal in which the main pedestrian axis on the raised level that cuts through the mall, Radboud Passage, would have its equivalent on the ground floor or street level (see Figure 3.4). The ABP, the owner of the mall, reacted furiously to the plan, and, because of the unrest it caused among the partners, the planning group - after a turbulent period of six weeks - was disbanded. 
In the ABP's view. the plan entailed the demolition of a crucial part of Hoog Catharijne." Serving as the main pedestrian antery from the old part of the inner city to the railway station, Radboud Passage constituted an essential part of Hoog Catharijne. according to the ABP. Becaluse most shops of the mall were located along this palssage, it generated major profits for its owner.

As indicated above. the ABP wanted to expand and remodel Hoog Catherijne rather than demolish sections of it. Already in 1987, the ABP and the management office of Hoog Catharijne were making concrete plans to "revitalize" the mall. The outdated interior of Hoog Catharijne had to be transformed into a more attractive design with more daylight, bright colors, and newly designed furniture. One of the underlying goals was to make the mall less attractive for homeless people and drug addicts." Macrander, director of the management office, proposed the creation of a second main pedestrian route through Hoog Catharijne. He defended a widening not only of Raldboud passage. but also of Gilden Passage. According to ABP manager Ed Bolt. it was important for a shopping center to function well in its totality. Radboud Palssage wals alwalys crowded, but the rental spaces in the so-called "Gilden quarter" section (ef. Figure 3.3) were not doing well at all, which meant declining profits for the company. Therefore, in the ABP's effort to construct a pedestrian circuit at the elevated level, Gilden Passage played a crucial role. To establish a more even spread of the visitors of Hoog Catharijne throughout the complex. Gilden Passage had to be enhanced by transforming it into a passange lined with shops."

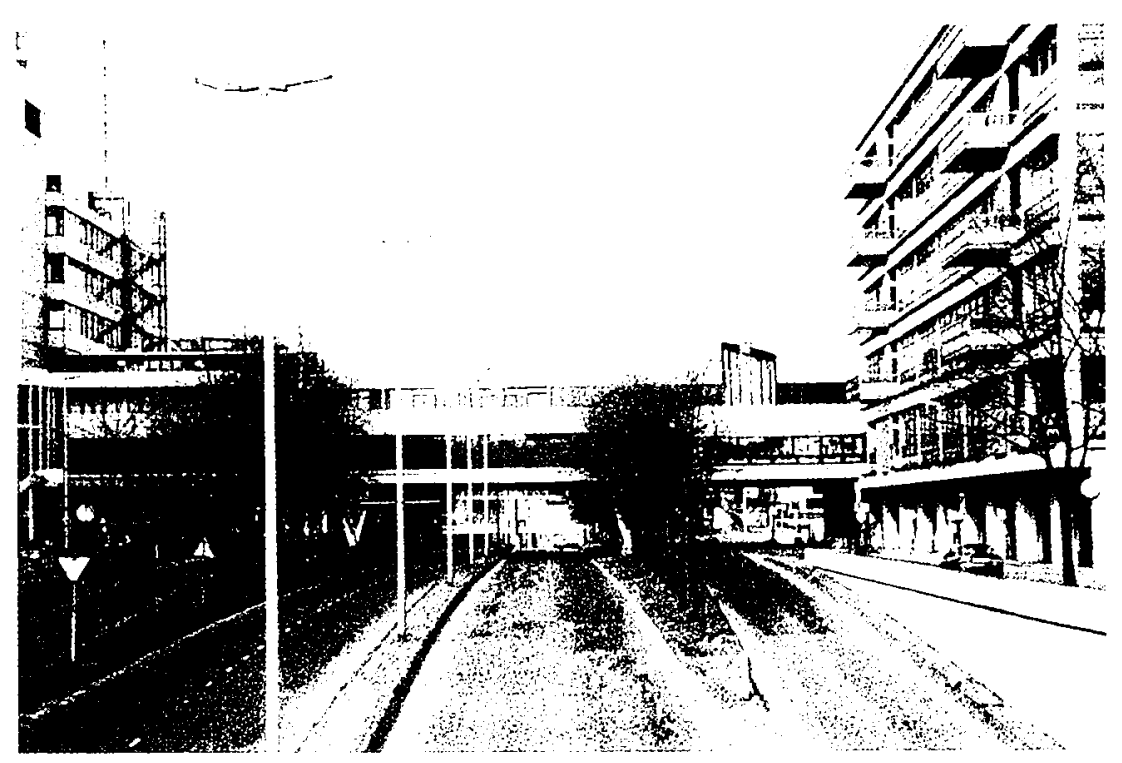

Figure 3.4: Radboud passage and Catharijnebaan (1) Picture taken by $\mathrm{A}$. Hommels

Instead of viewing Gilden Passage as a potentially vital clement in the functioning of Hoog Catharijne, the city stressed that this section of the complex was 
not operating well. City board member Ger Mik dismissed the proposal to improve it als "not righ" and "not sensible". Because the city considered Gilden Passage an ineflective connection between the old part of the downtown district and Hoog Catharijne, it even proposed to tear it down and replace it with a street level passage. By contrast. in the ABP's technological frame the overall enhancement of the raised level was a major goal. It reasoned that this level's commercial potential would greatly benefit from having a circular pedestrian route, a widening of its passages, and the introduction of shops along Gilden Patssage. Because of the company's high inclusion in this technological frame, it could only generate alternatives within the parameters of the existing design. Thus the obduracy of Radboud Passage emerged as the major factor in the negotiations.

In December 1990, the UCP was designated a potential "key project" by the national government. This status implied that the project, because of its national significance, might be cligible for substantial governmental subsidies, which, in turn. functioned as a strong impetus for incorporating governmental policies and rules in order to attain the key project status. This led to the so-called Project plan." designed to incorporate these governmental guidelines.

At this stage, the ideal of the compact city. combined with NS projections of a doubling of the number of public transportation passengers and data that signalled an increase of the overall population. caused the city to believe that the number of passengers at Utrecht Central Station were likely to go up even more than was assumed initially." To meet the anticipated demand, the NS was planning to build a second railway station near Central Station. Obviously, this would have major consequences for the pedestrian routes connecting both stations and the inner city. The ABP, however, disagreed with the data put forward by the city and the NS: it only projected an increase in pedestrian activity of $6 \% .^{\text {"N) }}$ The ABP acknowledged that if the number of passengers would double. Hoog Catherijne would indeed be unable to accommodate such growth. Since the ABP's technological frame was mainly driven by commercial concerns, the company stressed that solutions should not only consider planning aspects, but business economics as well."

The city and the NS nevertheless succeeded in integrating their "data" into the new plan. which proposed the design of four pedestrian axes on the ground floor instead of one central axis at the raised level. Moreover, it called for a new ground level axis that cut through the existing Hoog Catharijne buildings at Vredenburg Square (see Figure 3.3). Clearly, it was hardly a plus in the city's frame to maintain all the existing Hoog Catharijne buildings. The street leading to the Station Square had to be improved by adding street level shops, while at the same level new entrances to Central Station were needed. Morever, the Project plan mentioned the idea of returning water to the Catharijne camal that had been paved over in the 1960)s." The city considered this element in the plan of crucial importance. Ger Mik. the city board member in charge of UCP between 1990 and 1994, considered the recovery of the canal as proof of the city's commitment to recovering urban public space" (see Figure 3.5).

Although the city and the ABP still disagreed. the former decided to submit the Project plan as the basis for governmental subsidies." The ABP objected to the plan because of commercial reasons: the plan would not be financially feasible. leaving a 
deficit of 300 million guilders. Moreover, the company feared profit losses: the city's plans would cause a decline of potential customers because with street level pedestrian routes people were no longer obliged to enter and cross Hoog Catharijne.

Despite the ongoing disagreement with the ABP during the next stage of the process in which the UCP Master plan was designed, the city held on to the idea of creating street level pedestrian axes. In an effort to prevent this idea from becoming a reality, the ABP conjured up official agreements signed by the city in the 1960s. If the new central street level axes were put in place, official agreements dating from the 1960s would be broken."

This legal threat could not prevent a new central axis on the ground floor from being part of the UCP Master plan that was published in May 1993." The UCP Master plan revived the "grid" as a central concept. A grid is an orthogonal screen of public streets that, in principle, are equally important. The grid structure of the area had to be improved by adding a new axis at the ground floor level. To create this axis, a passage with a width of 22 meters had to be cut through the existing buildings of Hoog Catharijne. The new axis would be the shortest route from the old town center to the entrance of the railway station. This axis was explained as a key ingredient of the ground floor model. For the ABP, however, the new axis was unacceptable if it would facilitate a shorter and more comfortable connection between Central Station and the old city center." Moreover, ABP manager Ed Bolt opposed the idea that the plan called for a twenty-two meters passage, whereas Radboud Passage, the main raised pedestrian passage through Hoog Catharijne, was only nine meters in width."

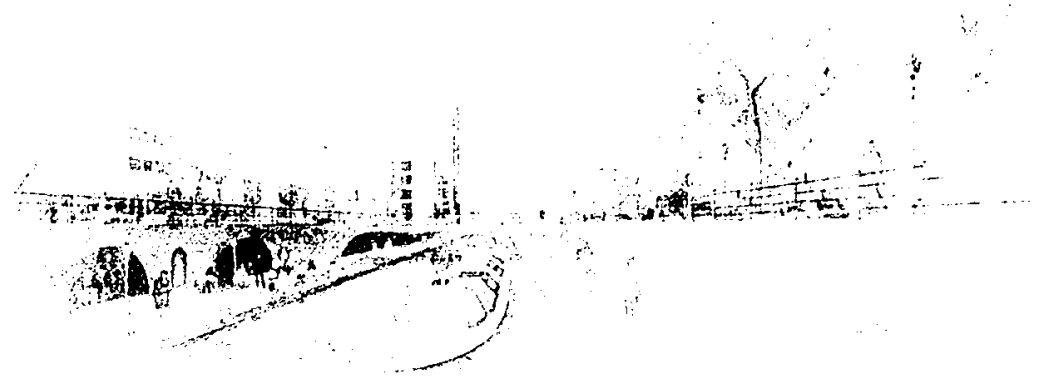

Figure 3.5: Artist impression recovery Catharijne canal UCP Master plan Source: UCP Masterplan (1993)

The ABP did not agree with the Master plan, nor did it sign it. The company's main objections concerned the economic feasibility, the new central axis and Gilden Passage. ${ }^{(x)}$ Moreover, the NS refused to sign the financial paragraph. In the meantime. 
however, the declaration of intent with the NS, the Industries Fair and the ABP had expired. so the city had the opportunity to continue the planning process with new partners. In Maly 1994. the Development Company, Ltd. was founded. a collaborative effort of the city and a group of project developers." Its aim was to make a feasible town plan based on the Master plan. Owning $51 \%$ of the shares, the city had at very strong position in the Development Company; it could force specific decisions in this way - and it did.

This collaborative effort resulted in a new town plan, called the "Spatialfunctional concept"' (see Figure 3.6). This plan was very much in line with the city's ground floor frame:

\begin{abstract}
With its decision to upgrade the public environment at ground level, the council chose to add a fully fledged piece of city at ground floor level to the old inner city. and to declare large areas of the public space at street level to be the domain of the pedestrian and the cyclist."
\end{abstract}

Moreover, it was emphasized that the enhancement and re-establishment of functions at the street level would improve the "morphological cohesion" of the modern Hoog Catharijne complex and the old inner city."

The plan again proposed an axis at street level between Vredenburg and Station Square. It thus provided two possibilities to reach the railway station: via the raised level of Hoog Catharijne and via street level. In the plan, the new ground floor axis directly led to a completely new railway station. The new station's central hall was commected to Hoog Catharijne only by a pedestrian passage." The Gilden quarter area, connected to Vredenburg by a raised passage, would have a new street level entrance. Furthermore, the ground floor domain was to be improved by the introduction of shops and cafés.

After the publication of the Spatial-functional concept, it turned out that the former partners (ABP, Industries Fair and NS) strongly objected to the plan. Not only were they upset about not being consulted during its development, they also felt that the plan violated their rights. They were all but prepared to give the city and the project developers permission to rebuild their property on the basis of the new plan. Moreover, after its publication it became clear that the project developers were not entirely satisfied with the plan either. In the absence of a fair decision process and because of a lack of confidence between the city and the project developers, their collaboration was discontinued."

During the period between the Perspectives report (1989) and the Spatialfunctional concept (1995), the city succeeded in pushing decisions that were increasingly irreversible and that profoundly influenced the later plans. For one thing, its preference for the ground floor model became incorporated in all of the subsequent plans. Statistics, projections of increasing pedestrian flows, governmental policies and city board decisions were deployed to promote town plans that were based on the ground floor model. Although the ABP tried to destabilize the plans with reference to previously signed contracts and cost-benefit analyses, the officially published plans show that the ground floor model increasingly functioned as the major planning guideline. 


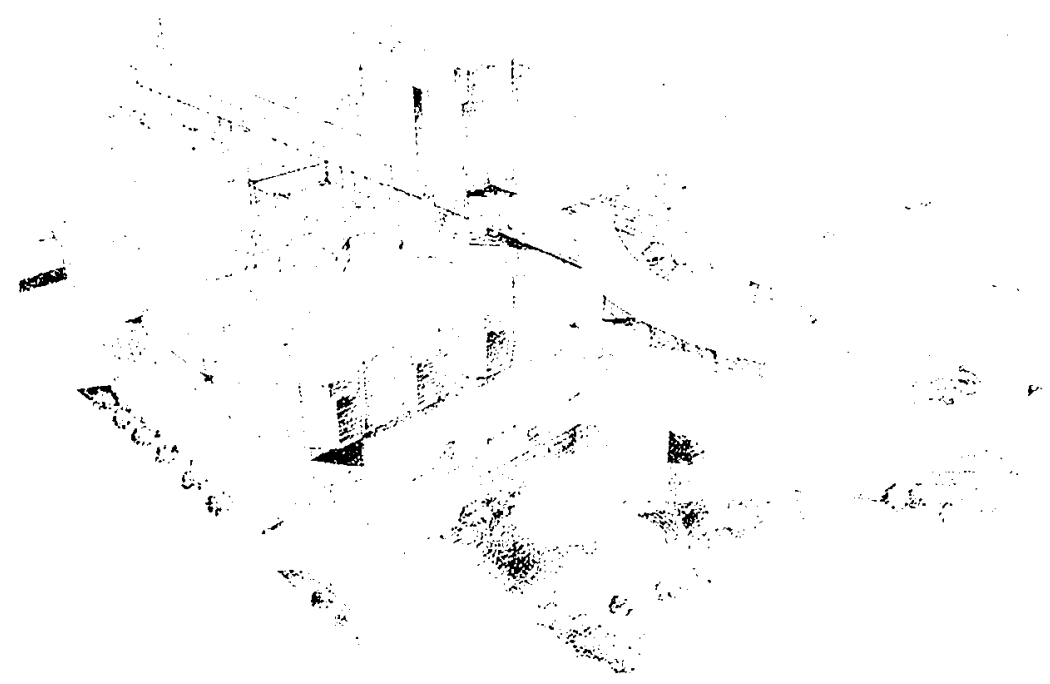

Figure 3.6: Artist impression Spatial-functional concept

Source: Projectbureau UCP Utrecht

My analysis so far demonstrates that Hoog Catharijne's obduracy was closely tied to closed-in obduracy: both the ABP and the city took a stance that suggested their high inclusion in a particular technological frame. These two actors could only think in terms of the raised level frame and the ground floor frame, respectively. They only saw alternative designs or tried to stabilize designs that fitted their frame. Arguments that played a major role in one frame were not considered relevant in the other. This limited the available redesign options either to versions of the raised floor model, which basically all involved an effort to raise the profitability and effectiveness of Hoog Catharijne's existing raised level configuration. or to versions of the ground floor model, which were basically all motivated by the desire to better integrate the ground floor level functions into the overall structure so as to improve public safety as well as the overall quality and liveability of urban space. The closed-in obduracy that resulted from the ABP's and the city's high inclusion in their respective frames had far-reaching consequences for the planning and decision processes: the rigidity of these opposing frames caused a deadlock in the planning process.

The specific design proposals made by another actor involved in the negotiations involving Hoog Catharijne's redesign, the concerned residents of Utrecht, can be explained by the low inclusion of this group in these two dominant technological frames. Free from rigid frames, some city residents made radical redesign proposals for Hoog Catharijne that did not fit either of the two dominant technological frames. This did not imply, however, that this freedom also gave them more possibilities to influence Hoog Catharijne's future, that they could bend things to their will. Below, I argue that what Utrecht's residents were faced with was "closed- 
out" obduracy.

\section{Closed-out obduracy}

Despite the residents' opposition to Hoog Catharijne in the 1970s, the complex gradually became accepted as a fact of life. Even in a 1997 newspaper article someone involved in the colossal complex"s initial design still commented that it has such presence that "it cannot be ignored by anyone and that we are all forced to take it into consideration." Over the years, city residents began to take Hoog Catharijne for granted in its existing form without attcmpting to change its character. However, in the course of the 1990s, some groups of residents became actively involved in the plans to change Hoog Catharijne. In 1990. a group of concerned residents, who wanted to influence the planning and decision processes involving the UCP. founded the Residents Committee City Project (BOCP)." It argued that the UCP should primarily pursue the re-establishment of public safety and the improvement of the liveability of the area around Hoog Catharijne. Although the BOCP never explicitly expressed a preference for either the ground floor model or the raised floor model, it favored the former. Among other things, it argued that the existing separation of traffic flows should be given up in part and replaced by an integrated flow of pedestrians, cyclists and public transportation." The Residents Committee pointed out that the planners should pay extra attention to the architecture at the ground floor, that houses should be planned at the street level, and that at that level safe walking routes from the city center to the railway station should be created as well. ${ }^{100}$ Pedestrians and cyclists should have absolute priority in their opinion, while the area's automobile traffic ought to be limited drastically."

Although these ideas seem well in line with those of the city, the residents had different priorities. The BOCP argued that the UCP goals had shifted as a result of the governmental policies in the field of urban plamning. In contrast to the city. the BOCP saw a tension between the goals of governmental policies and the need to improve the liveability and public safety of the city. It stressed the importance of bringing back a sense of "human scale" to the area. This meant that large-scale building had to be avoided and that the preconditions for public safety and urban liveability had to be specified. Subsequently, it could be determined which functions would be necessary to finance this. " Leo Lambo, former coordinator and secretary of the BOCP, suggested that the BOCP was never against the UCP: "We have always said: "The UCP was necessary, because something had to be done to improve the area. But the surrounding neighborhoods should not be negatively affected.'

Some residents, who believed that minor adjustments of the existing Hoog Catharijne design would not solve the public safety concerns in the area, proposed a rigorous demolition of the complex. This would create, according to one resident. building space for a new town plan that would be more "humane". He argued that it would be impossible to solve the public safety issue if the plans basically implied a continuation of the present structure."

A detailed plan for the demolition of Hoog Catharijne was put forward by the Utrecht architect Clemens Koemans (See Figure 3.7). Koemans was very critical of the UCP plans and entirely displeased with the existing architecture of Hoog Catharijne. In 1993, he participated in meetings of the Utrecht Architects Café, where experts 
elucidated the UCP plans as a way to involve the general public. Expressing his critique during one of the meetings, Koemans received support from Leo Lambo of the BOCP. Later he contacted Lambo and communicated his idea of making an alternative town plan based on his criticisms of the UCP. Koemans:

\begin{abstract}
Lambe told me that I coukl get all the information he had. He played a pivotal role in the alternative seene. I have alwalys regarded them as a client in a way. But I have done this voluntarily. withou being paid for it... The BOCP has never fully accepted my plan. They sympathized with it. thought it a nice alternative. but 1 introduced the plan as my own. ${ }^{\text {: }}$
\end{abstract}

Koemans proposed his plan for a city park on the location of Hoog Catharijne. He argued for a "humanist" town planning perspective: Presently, people were compelled to pass through the mall. but Koemans felt that they should have the option to choose altemative routes. Becaluse it would be impossible to implement a new shopping concept in the present structure of Hoog Catharijne, his plan comprised the all-out demolition of the mall." The plan was rejected on straightforward grounds: "to ascertain that a demolition of the Hoog Catharijne complex is unfeasible" hardly needed elucidation. ${ }^{10 x}$

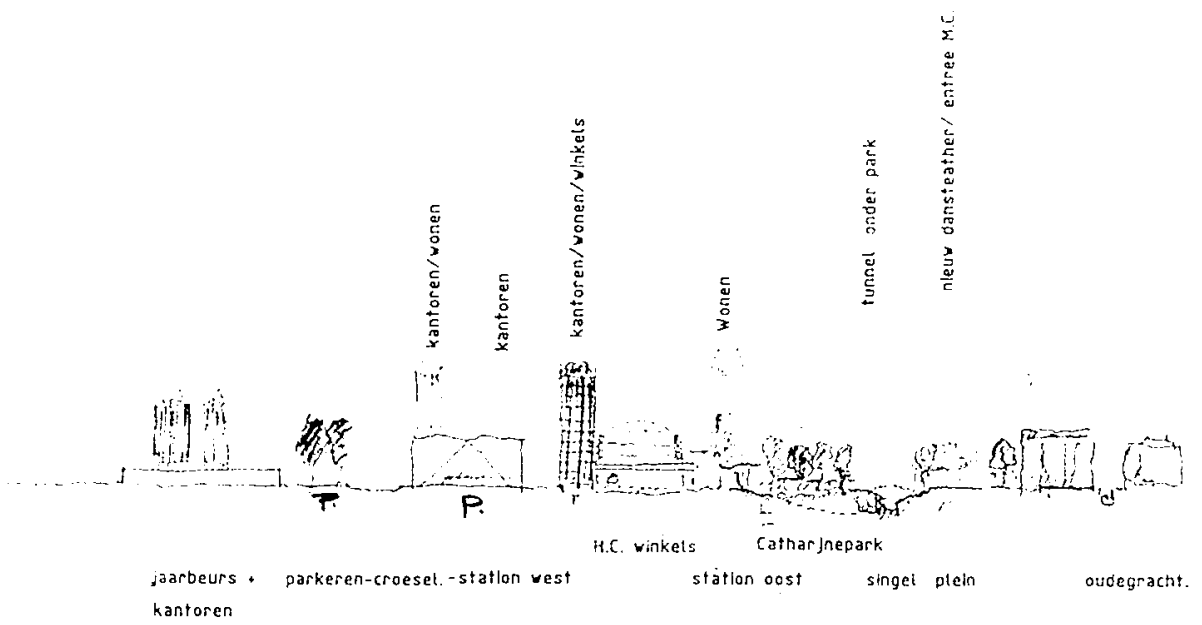

Figure 3.7: Plan Koemans

(1) Clemens Koemains

This example can be understood in terms of Bijker's analysis of closed-out obduracy. It shows that Hoog Catharijne has such an uncompromising presence to some of the residents or users, that these actors can only conceptualize it in terms of a "take-it-or-leave-it" choice. Actors with a low inclusion typically either propose radical alternative technological designs or decide to accept the design as it is. Both strategies are visible in the history of Hoog Catharijne. Instead of trying to adapt the 
existing design of Hoog Catharijne, some residents completely dismissed it. Whereas the city and $A B P$ tried to think of alternatives within their technological frames, these residents - being closed out of the existing frames - saw no alternative designs within these frames. In their view, Hoog Catharijne should be either demolished or accepted as it is.

My argument in this chapter demonstrates how technological frames influenced the plans for redesigning Hoog Catharijne and how the actors were caught up in closed-in and closed-out obduracy. But now the question arises if or how change was possible at all outside these frames"? Is it possible to transform or abandon dominant technological frames, and, if so, in what ways? Or, in other words, how can these types of obduracy be overcome?

\section{Overcoming obduracy}

Despite all of the city's efforts to promote a serious redesign of Hoog Catherijne's ground floor level in particular, as a significant contribution to the overall recovery of Utrecht's downtown district, the Utrecht City Project became increasingly associated with a negative image. Therefore, in 1995 the name of the project was changed into Utrecht Center Project to mark a new start."'1' After the failure of the Development Company in that same year, the city decided to open up the discussion again with its former partners. It was fully aware of the importance of such a renewed cooperation. since an investigation of the failure of the Development Company by a consultant had shown that close collaboration between the partners would be indispensable for a successful town plan, which, after all, depended on support from various actors. "1" The city and its partners were convinced that their negotiations had reached a "now-ornever" stage: at once, they realized that this was their last chance." A new official agreement was signed by the four partners, comprising new financial arrangements. It was decided to divide the UCP-area into four parts, one for each partner. The partners would lake the financial risks for their own area. A fifth part, consisting of infrastructure and public space, would be financed by subsidies from the national government and profits from the other four areas. ${ }^{12}$

In 1995, the mayor of Utrecht, Ivo Opstelten, personally asked Riek Bakker, town planner and former director of Town Development of the City of Rotterdam, to become the new town plamning supervisor. Bakker was particularly interested in the process of town planning and its strategic aspects:

Bringing together all ... vested interests takes a lot of time. energy and, in particular, much patience. One of the reasons is that interests will often contradict each other. Of course. the town planner has to avoid becoming a (political) 'party' in such a process. Everyday practice suggests that political and diplomatic insight is desperately needed. The biggest chance of success. however, is based on the approach taken: from the outset the town planner looks for a solution to the issue as a whole, and this includes taking into account all the various interests."

Initially, her task was to further develop a town plan on the basis of the Spatial- 
functional concept.".' Bakker, however. was not entirely convinced of the quality and feasibility of this plan and proposed to start from scratch by analyzing the concrete problems in the Hoog Catharijne area. In this process, she devoted particular attention to the vested interests in the area and to the views and preferences of the partners involved." By taking into account the history of the two technological frames and by confronting the partners with their dogmas. she developed a new town plan that got the support of Utrecht's city council and the partners."

A preliminary town plan was published in February 1997." Although this plan was presented as the "logical" next step after the Spatial-functional concept. it was an altogether new plan based on different assumptions. " The key feature of the plan was a large inclined square, as a bridge between the ground floor and the raised level (see Figure 3.8). To allow for the construction of this square, the entire Gilden quarter areal hald to be demolished. while a part of the remaining Hoog Catharijne complex had to be split in (wo. The square should function as a connection between the street level and the railwaly station. City town planner Evelien Brandes pointed out that Central Station, instead of being an integral part of the shopping center, ought to be an independent building. and that the inclined Station Square should be an open-air public space. "1" After having arrived at Central Station. passengers should be able to enter the square at the street level or proceed through the mall. The station entrance, however. was still situated alt the raised level. ${ }^{\text {rn }}$ The idea to return water to the Catharijne canal was preserved from earlier UCP proposals. Radboud Passage was going to be widened and Hoog Catharijne would be rearranged in the style of American shopping malls.

Bakker's town plan seemed to harmonize well with many of the partners" points of view, but the plan also included elements that strongly conflicted with positions that had been articulated earlier in the UCP process. How did Bakker manage to achieve a reconciliation of such diverging ways of thinking? What was so remarkable about her plans and strategies that the partners were willing to forsake their firmly established positions?

The strategic talents of Bakker and her experience with the complexities of the procedural aspects of town planning projects significantly contributed to her success in the UCP. She was praised for being a "real personality", for her "outspoken language", her "guts to tell the truth", and her ability to say the right things at the right moment. In the words of Bart Lambooy, Bakker"s advisor in the UCP: "she does a lot of "massaging' behind the scenes". Moreover, he emphasized that Bakker was a woman. "She functions in a man's world. And one way or another, she knows exactly how to handle that world, twisting all those men round her finger." characterized her role in the UCP as that of "organizer, communicator, postiljon d'amour, binder, trustee."

Bakker also took advantage of the many changes that had taken place in the organizations of the city`s partners. Their views, the issues and goals had gradually become defined differently. The ABP had reorganized its investment funds and had founded the WBN (Winkel Beleggingen Nederland), a shopping center investment fund. WBN became the new partner in the project. In the meantime, the NS Railway Company was privatized. New ideas had emerged about organizing public transport and integrating different public transport systems (bus, tram, train) at one location, which led to a new "mainport" concept for Utrecht Central Station. The Industries Fair 
had developed a new business philosophy and this had major consequences for their goals in the UCP as well.

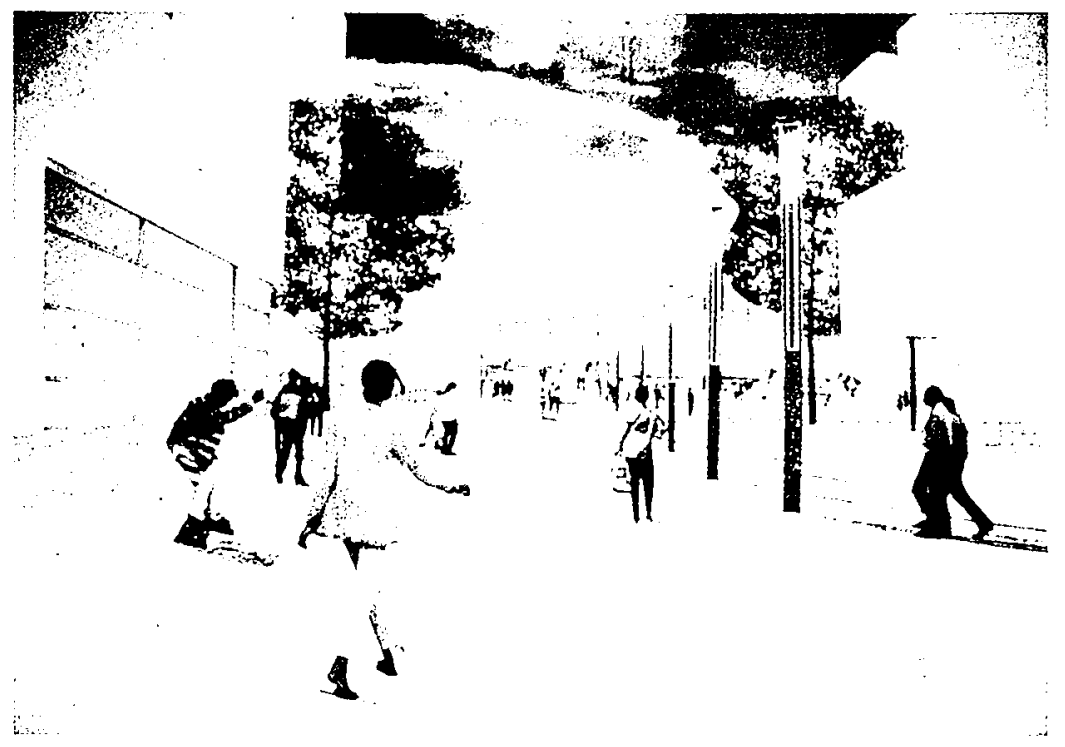

Figure 3.8: Artist impression inclined square (1997)

Source: Projecthureau UCP Utrecht

At this stage, several crucial redefinitions resulted in an increased malleability of Hoog Catharijne. Instead of choosing the ground floor model as the basis for the plans, the partners agreed that the raised level should be the point of departure. the city project manager for UCP. Ad Smits, pointed out:

The dogmatic discussion about shopping at street level. street level access to the railway station and the competition this would imply for Hoog Catharijne. which is situated at 6 meter above street level. was solved becaluse the parties agreed from the outset of this new phase: the raised level is the point of departure ... There has been a profound change in the city's way of thinking."

City board member for UCP. Herman Kernkamp, argued that Bakker solved the discussion by making clear at the beginning that it was a great misunderstanding to speak about the two town planning models. According to Kernkamp,

The essence is that if we try to enhance the quality of the public space and the safely of the people who use that public space. we hold on 10 a kind of ground floor model. but we should also maintain the raised level of Hoog Catharijne."

Kernkamp agrees with Bakker: 


\begin{abstract}
Bakker said: "Hoog Catharijne is okay. It is a magnificent east-west axis. You should honor that. It was a very good concept at the time when Hoog Catharijne was built, a brilliant idea. It should be maintained that way." When this was made clear, the city council and the other parties considered it an eye-opener. We said: "Let's please fix this town planning concept.".
\end{abstract}

The city thus redefined the raised level as a "brilliant town planning concept." By situating the raised level of Hoog Catharijne in a tradition of daring architectural choices, it became easier for the city to make this switch without loss of face. Hoog Catharijne had long been a kind of trauma for the city, but by using this argument Bakker provided a reason for the city to become proud rather than ashamed of it. Reconceptualizing Hoog Catharijne's design as not so bad after all implied that the city had not made such a huge mistake in the past.

Another crucial redefinition that took place at this point concerns the contrasts between the inner eity and the Hoog Catharijne area. As suggested above, the city had always wanted to make the boundaries between the inner city (old, open air, ground floor, small-scale) and the Hoog Catharijne area (new, roofed, raised level, large-scale) more fluid. At this stage, however, the city began to bring out the differences and dissimilarities between the two areas more clearly. ${ }^{127}$ Since upgrading the ground floor level was previously seen as the major strategy in diminishing the differences between the inner city and Hoog Catharijne, the aim of strengthening the contrasts decreased the importance of developing the area according to the ground floor philosophy. Moreover, one of the features of Bakker's plan that was crucial for the city was the proposal to return water to the Catharijne canal. ${ }^{2 n}$ This idea had an important symbolic value in the eyes of the city residents: it reminded them of the canals of the old inner city, an aspect of Utrecht that is greatly admired by locals and visitors alike.

Bakker's town plan also included a radical renewal of the raised level, including the demolition of $25 \%$ of the Hoog Catharijne complex. This was partly possible because of WBN's redefinition of its shopping center. The WBN started to make a distinction between Hoog Catharijne as a "run shopping center" and as a "fun shopping center". At present, Hoog Catharijne is still a run shopping center. Many people run through it quickly because it is still the only, relatively nice and safe way to go from the railway station to the old city center. These people do not necessarily buy anything. The WBN's goal became transforming Hoog Catharijne into a center for "fun shoppers": people should come into the center and be persuaded to buy products by an attractive interior design and quality shops. Turning Hoog Catharijne into a fun shopping center would require radical remodeling. ${ }^{121}$ This redesign plan started from the existing main raised pedestrian passage, Radboud Passage. It should be widened by 2.5 times its present width. ${ }^{131}$ In this new mall concept, it was no longer required that every pedestrian that walked from the train station to the old center passed through Hoog Catharijne. Thus, the possibility for a second main pedestrian route, via the inclined Station Square, was created.

In this phase of the process, redefinitions of goals and ambitions and new developments caused a renewed flexibility of Hoog Catharijne. The two rigid technological frames that for so long had dominated the choices and interactions gradually receded to the background. And, not surprisingly, from this moment the 
plamning process seemed to make progress: Hoog Catharijne regained its malleability. Part of Bakker's success can be explained by the fact that she was an outsider to the almost decade-long process in which two technological frames had dominated the interactions. In STS-literature it has been argued before that frequently outsiders are needed to reject a dominan "mental model" or specific worldviews (see Chapter 2). "i1 Bakker, without any prior stakes in either one of the technological frames, succeeded in combining elements of both. Thus, actors do not always have to be either "closedin" or "closed-out" of dominant technological frames: Bakker was "closed-out" enough to be able to develop alternative designs and "closed-in" enough to understand the backgrounds of the two technological frames. In this way, an "amalgamation of vested interests" occurred, one that is typical for stabilization processes in situations with two or more dominam technological frames. This involves a strengthening of both the ground floor and the raised level: in Bakker's plan the "ground floor" is upgraded by filling the canal with water again and by reducing Hoog Catharijne's size by tearing down part of it and splitting the remaining structure in two, while the "raised level" is enhanced by widening Radboud Passage and building the inclined station square. Central Station will eventually become a separate entity again, and the Industries Fair will have better connections with Hoog Catharijne and the inner city. In this way, all partners could consent to the plan without loss of face. Bakker's town plan was approved by the city council on 18 Decomber 1997 and. if the council follows up on its decision, it will be the definitive plan for rebuilding the area near Central Station as an integral part of Utrecht's downtown district.

\section{Obduracy and dominant ways of thinking}

The town planning concept on which Hoog Catharijne was originally based, a strict separation of traffic flows resulting in a design with raised pedestrian passages, had acted as a guideline for all planning proposals that were made for the area. In this chapter. I analyzed the attempts that were made between 1987 and 1997 to reverse this concept. It was initially transformed into a model in which street level pedestrian connections became the guideline: the so-called ground floor model. Although the city and the NS Railway Company successfully linked this model to governmental policies and subsidies, statistics, and future prognoses, they did not succeed, in the end, to get this model implemented. Some elements of Hoog Catharijne, the raised pedestrian passages in particular, were obdurate - hard to change or demolish. The ABP vigorously tried to block every effort to transform these elements.

The history of the UCP presents an example of obduracy caused by the dominance of certain "ways of thinking" or technological frames. In the interactions among the partners two technological frames werc built up that became increasingly fixed. Because of their high inclusion, the city and the ABP could not think of alternative designs outside the ground floor frame and the raised level frame. The rigidity of the opposing technological frames over the years led to a deadlock in the planning process. Only a limited number of alternative designs were proposed that either were in line with the raised level frame or complied with the ground floor frame. Residents, on the other hand. were closed out of the dominant technological frames 
and could only think of radical alternative designs. outside these frames. The closedout obduracy experienced by citizens became apparent by their proposals for radical changes of Hoog Catharijne. including its demolition.

An outsider was needed to reconcile the two dominant frames. However, not all outsiders were equally capable of rejecting the established ways of thinking. Citizen groups, such as the BOCP. or architect Kocmans were outsiders who did not succed in bringing about change. Bakker did. Her advantage was that she was an expert who was allowed in a position that enabled her to understand the backgrounds of the two technological frames and to exploit her strategic capacities in her interactions with the partners. Several redefinitions of goals and ambitions and the presence of new actors in the planning process after 1996 thus led to an increased malleability of Hoog Catharijne.

Bakker and her co-workers developed a strategic town plan that incorporated aspects all partners could agree on, but residents of Utrecht remained critical of the project. Before the city elections in the spring of 1998, a new political party was founded, called "Liveable Utrecht" (Leefbaar Utrecht). This party's main goal was to prevent the execution of the Utrecht Center Project. Although Liveable Utrecht became the largest political party of Utrecht after the elections, they did not join the city board.

In this chapter. the notion of dominant ways of thinking, the technological frame concept and the distinction of closed-in versus closed-out obduracy have been useful in analyzing different types of obduracy for different groups of actors. The focus was on a major urban redesign process and on how, specifically, interactions at the local level between social groups, their constrained ways of thinking, and their strategies influenced the obduracy of Hoog Catharijne at various stages. Despite these advantages, I could highlight only a limited number of aspects of obduracy by using this specific theoretical approach. Other explanations for the particular difficulties of changing Hoog Catharijne may be revealed by other theoretical approaches. Alternative explanations, for example, may dwell on Hoog Catharijne's legal embeddedness in a contract between the city and builder Bredero ${ }^{13:}$ or on its geographical embeddedness in the central part of the city. encapsulated as it is by the extensive train tracks. the Industries Fair and the old inner city. A focus on "embeddedness" would reveal aspects of obduracy that were not explained by the theoretical approach used in this chapter. In the following chapter, then, I will explore this issue of embeddedness and apply it to another case study. 


\section{Obduracy and Embeddedness: Trying to Reconstruct the Highway That Cuts Through Maastricht}

\section{Introduction}

The highway stretch that cuts through Matastricht was built in the late 1950s. At that time, when cars were still comparatively sparse in the Netherlands. there seemed to be many good socioeconomic reasons for building highways near downtown districts. Moreover, noise regulations did not yet thwart the construction of apartment buildings adjacent to highways. Between the early 1960s and the late 1990s, however, several interconnected processes have radically changed the issues involved in highway design: car traffic rose dramatically; traffic safety and the quality of urban life became increasingly important issues; environmental concerns started to play at more important role in traffic projects; stricter envirommental norms, regulations and standards for the design of highways were developed; activists and lobby groups began to influence urban redesign projects; and local, regional, national and international governments changed their policies on traffic circulation, in part because of other financial priorities.

Since the construction of the highway in Maastricht, there has been an ongoing effort of engineers, politicians and citizens to change and adapt it. From the beginning it was clear that the highway, which just to the south of the city serves as an important link between the Dutch and the Belgian highway network, basically split the city in two. Over the years. provisional adaptations were made, such as the reconstruction of intersections and the placing of sound baffles, but more radical new designs, such as overpasses or a diversion east of the city, failed to be adopted. The idea of a tunnel, as the definitive solution to the traffic congestion, the reduced traffic salety, and the limited quality of life for those who live near the highway, has been considered and reconsidered for as long as forty years. Although this idea has figured prominently in the various municipal policies, proposals and strategies, so far this solution is not even close to being implemented, nor is any other solution. Given the concerns of my study, this raises a number of concrete questions. How could this urban highway stretch build up and maintain its obduracy? What were the strategies employed by the various actors engaged in the effort to improve the highway"s design? Why is it that the highway that cuts through Maastricht has virtually remained unchanged for almost half a century? 
In this chapter, I analyze the effort to adapt the highway's design from the early 1960s until 1998. Specifically, this case study addresses the role of embeddedness as a major explanation of obduracy. This theoretical notion refers to the increasing interrelatedness of sociotechnical elements over time as a way to account for urban sociotechnology's resistance to change. In the previous chapter it was shown that a high degree of inclusion of actors in specific technological frames resulted in obduracy. Because technological frames are usually tied to specific social groups, this interactionist theoretical perspective only provided a partial explanation of what constitutes obduracy. Major urban structures, however, tend to be embedded in a larger built-up urban environment and this generally causes major challenges when for some reason that structure needs to be redesigned. In this chapter, I argue that the highway's gradual integration in urban traffic schemes, user practices, town planning structures, local and governmental policies, and legal norms and regulations offers a different yet equally relevant explanation for its obduracy, its resistance to the effort to redesign it after its original construction. I also argue that specific design solutions that are not yet implemented, such as the tunnel option in this case. may become embedded in policies and the ideals and activities of politicians and citizens; as such, they become obdurate as well. Finally, I will focus on two different strategies of dealing with the embedded structures of the urban section of the highway and their implications: one in which the embeddedness of the highway was deliberately (albeit temporarily) disregarded, a method that opened up a wide array of redesign alternatives (the Infralab procedure), and one in which a direct confrontation with the embedded structures was sought (the Design Workplace).

But let me start by briefly outlining the context of the discussions in the Netherlands about the relationship between cities and highways in the postwar society. It will throw more light on how Dutch highways became gradually embedded in their immediate environment, why the highway through Maastricht was designed as it was, and why the present trajectory was chosen. Significantly, the issue of the highway's reconstruction was already mentioned at a very early stage.

\section{Designing and building Highway $75^{\prime}$ (1956-1960)}

\section{Highway 75: Should it cut through the city or go around it?}

In the years following World War Two, Dutch town planners, road engineers, politicians and policy makers began to frame the future of the city increasingly in the context of the "automobile era."- In 1948 the Dutch Road Congress Association (Vereniging Het Nederlandsche Wegen-Congres) organized a conference about the question whether highways should be built in or around cities. At that time, city highways with overpass junctions had already been introduced in several major cities in the United States, where initially they were mostly built through poor urban areas on the pretext of "slum clearance." When the urban freeway-building program was at its peak in the 1950s, and middle class neighborhoods began to be affected, protests aggravated and local action groups were established to stop these mega infrastructure projects.

One of the speakers at the 1948 conference, L.H.J. Angenot, director of the 
town planning department of Rotterdam, observed that such massive highway projects with fly-overs were still absent in Europe. Traffic congestion was not seen as a serious problem yet in European countries, and, moreover, in the years immediately following the war, funding went to projects that had more urgency than a state-of-the-art highway system. It seemed nevertheless obvious that automobile traffic would significantly increase in the years to come and Angenot suggested that it was necessary to begin thinking about the implications of this growth for cities and highway construction, and whether or not in this respect the American example should be followed."

The conference's main concern was how to reconcile the growing number of cars with the existing and future layout of cities." Another speaker, G.C. Lange, also a town plamner, argued that traffic congestion in cities might result from the difficulty to adapt roads. Over the years, houses in old neighborhoods had been replaced, but the roads along which they were built often remained unchanged for hundreds of years. This meant that minor adjustments in terms of width, trajectory or the number of crossings might still require radical and hence costly alterations. Furthermore, Lange argued that the design options of roads and streets in cities generally were quite limited; road curves in particular were much easier to design in the spacious countryside."

During the 1950s, the city of Maastricht, like many Dutch cities, had to address questions such as "where should the new highway be situated in relation to the city center?" and "how should it be designed?" The city board, in collaboration with Rijkswaterstaat," had considered plans for a north-south highway near Maastricht already before World War Two." Although Rijkswaterstaat initially projected the highway's trajectory to be further away from the city center of Maastricht, namely east of the eastern districts Heer and Amby, the road was eventually planned closer to Maastricht's downtown area." The Chamber of Commerce of South Limburg effectively lobbied for a road trajectory near the city's main industrial zones that happened to be adjacent to the downtown area." The companies, of course, would benefit from enhanced nearby infrastructure. Moreover, it was argued that in the case of a diverted highway trajectory to the east, the new highway would barely contribute to the local traffic circulation."

The city council of Maastricht was well aware of the new highway's significance to the city:

There is no doubt that Highway 75 is of ttmost importance for Matastricht. This crats traffic development depends on roads and highways rather than - as in the old days on rivers and railroads, and now that Highway 75 passes Malastricht it is important to effectively integrate it into the city's traffic system."

The city council also emphasized the necessity of good roads for the future development of Maastricht as an industrial center and underscored the significance of having a highway that connects the city to other parts of the country. It believed that for Maastricht. 
as a city at the intersection of cultures, good and fast comnections are necessary. ... When this highway is completed. Matstricht will eventually have a gond and fast connection with the central and western part of the country.

The director of the city's Public Works Department. J.J.J. van de Venne, argued that Maastricht fulfilled a major socio-cultural function for the region. ${ }^{1:}$ He felt that the new traffic plan should facilitate the fluid passage of international traffic through the city and that it should enable regional traffic to come as close as possible to the city's industrial areas and its public services and institutions. At that time, it was expected that Maastricht would obtain a key position between two main highways for which plans were underway: the highway between Antwerp and Aachen via Liège, south of Malastricht, and the highway between Antwerp and Aachen via Elsloo/Heerlen, to the north of Maastricht." Van de Venne also referred to the competition Maastricht might have to face of the nearby Dutch cities Hecrlen and Geleen:

If Maastricht wants to maintain its socio-economic influence and suecessfully compete with new developments like those in Heerlen and Geleen. the city will absolutely have to pursuce expansion and reconstruction ... in the near future."

The Public Works director perceived a direct link between the city's socio-economic ambitions and its traffic problems, and argued that the inner city, with its commercial district, should be accessible for cars by means of a circular system of roads.' The projected ring road was seen as the backbone of Maastricht's traffic circulation system and the urban stretch of Highway 75 constituted a part of it (see Figure 4.1):"

One of Matastricht's most important entranceways is the E-9 motorway or Highwaly 75. The urban stretch of this highway was under construction from 1958 to 1959 and forms part of the traffic circulation around the inner city."

Despite this enthusiasm, city council discussions in 1958 reveal the doubts of some of the council members about the chosen trajectory. In one of the council meetings council member Wishaupt wondered if it would not be better to build the highway on the outskirts of the city with branches leading into the downtown area." He also objected that the planned Highway 75 was part of plans for the extension of Maastricht that had already been ratified a few years before." Therefore, he claimed it was not possible to propose important adaptations. With reference to previous experiences in the central part of the Netherlands, it was argued that the building of highways around cities had obvious disadvantages. The chaiman of the council mentioned the example of Utrecht. where the highway allowed all through traffic to pass by the city altogether." It was thus eventually decided to situate the highway right through the eastern part of Maastricht, just east of the Malas River and the railroad tracks.

The highway engineers of Rijkswaterstaat may have had doubts about the suitability of this trajectory, because formerly it had been the site where the overflow of water from the river ended up. As Jacques Jamin, a Rijkswaterstaat highway builder, suggested in an interview: "an old saying in road engineering is that a road 
always needs to have dry feet":" It is therefore remarkable that the new road was planned in what used to be a very wet area. Because of the site's history as an overflow reservoir, it was a very low-lying area. with a comparatively high ground water level. This concern, however. would not reverse the plans. Clearly, the economic and socio-cultural arguments of the city leadership and the Chamber of Commerce prevailed and lixed the trajectory of Highway 75 at its present site: right through the city.

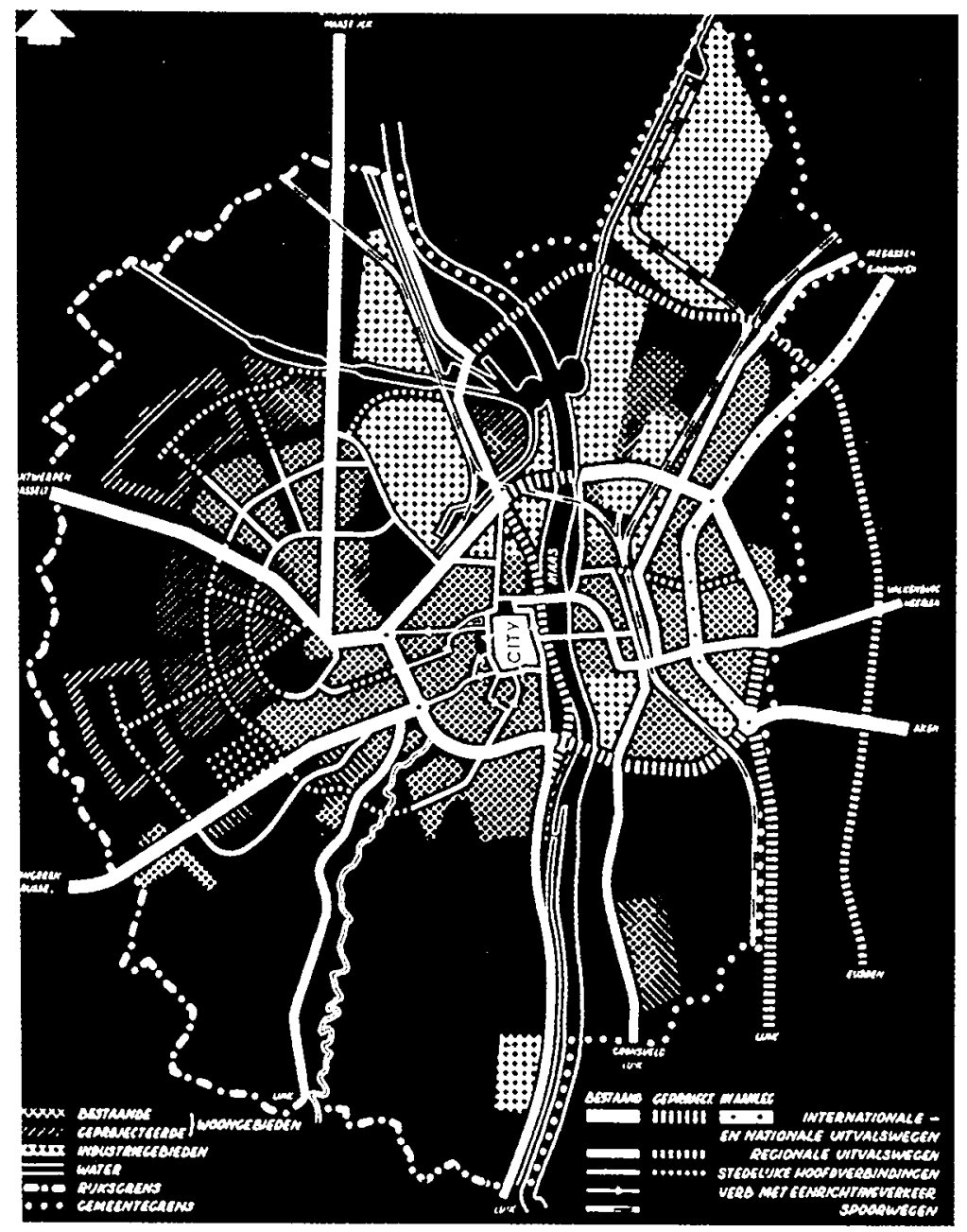

Figure 4.1: Highway 75 as part of the ring road Source: Van de Venne (1959)

Design of Highway 75

The actual planning and building of Highway 75 took place between 1956 and 1959. A decade before. Angenot, one of the speakers at the 1948 conference of the Dutch Road Congress Association, described three models of connecting a highway to a city." The 
first model involved a highway in or in the proximity of the city and a ring road or beltway outside the city. In the second model, called a "linear system," main highways were situated at a relatively large distance from cities; highway and city were to be connected by a network of smaller highways or secondary roads. In the third model, called the "palssage system," highways were led through the city. Angenot pointed out that the first and the second system were most common in the Netherlands at that time. In contrast to American cities, where highways often penetrated densely populated urban centers. European countries favored the ring road system. In the late 1940s, then. the passage system was very uncommon in the Netherlands. Its disadvantage, Angenot argued. was that frequently it fulfilled a "double" role: it not only channeled regional and national through traffic, but it also played a pivotal role in the local traffic circulation. Therefore he suspected that the passage system could easily cause congestion. In American cities, a ring road was often added to a highway, in order to diminish the inconvenience that local traffic caused for through traffic."

The way Highway 75 was linked to the city of Maastricht most resembled Angenot's third model: the passage system. Initially the plan was to construct overpasses at two of the main intersections with local roads: Geusselt and the Scharnerweg (see Figure 4.2)." The city supported this solution. In June 1958, some council members voiced their concerns about the level road junctions, especially with regard to the safety of school children that had to cross the highway. Moreover, they argued that the new highway would add a third north-south barrier to the city that was already divided in two by the Maas River and the railroad tracks. This is why they favored a highway that was built below ground level. Rather than opting for overpasses to allow for safe intersections, they favored lowering the new highway to achieve that same effect."

The Ministry of Transportation subsequently postponed the construction of overpass junctions. ${ }^{2}$ This meant that for the time being the intersections would remain at ground level. It was projected, however, that in the near future Highway 75 would pass below the Scharnerweg, a major intersection close to the Railway Station, while it would be elevated near Geusselt, another major intersection a kilometer to the north of Scharnerweg. At a later stage, the highway would ultimately pass below both intersections." This was the basic scenario in 1964, when Van de Venne claimed that "in the near future" the highway passage would be without level road junctions altogether, and only two access roads would link the highway to the city. "Still in 1969, the author of the city's Yearbook reported that the plans for realizing an urban highway without level road junctions have reached "an advanced stage." The author mentioned four intersections along the highway's urban stretch that, according to these plans, would be turned into overpass junctions. 


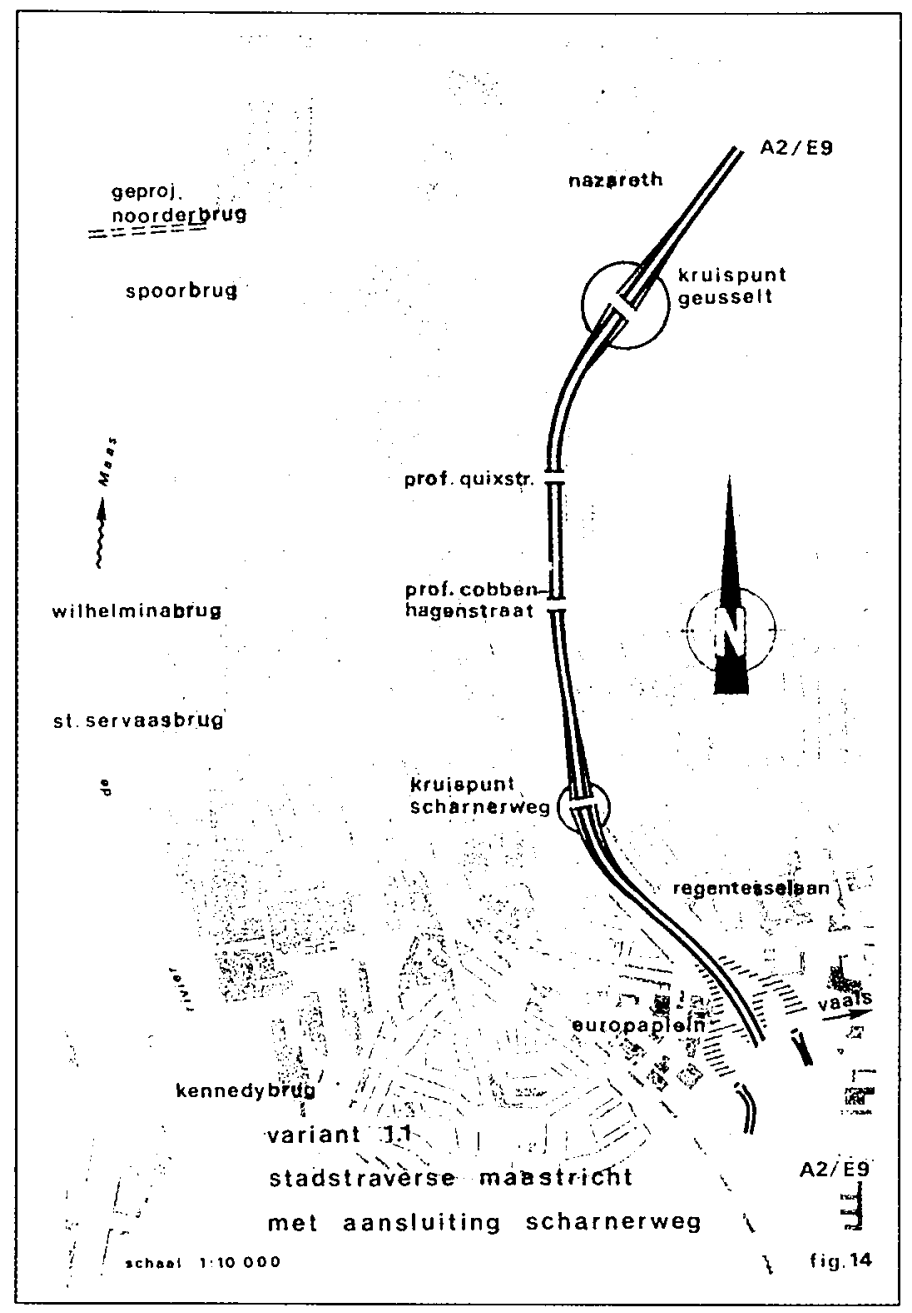

Figure 4.2: Urban highway with intersections

From north w) south: Geusselt. Scharnerweg. and Europaplein Source: Rijkswaterstat 1979) Rijkswaterstatt

Another option that wats put forward in the late 1950s was the idea of building a tunnel for Highway 75. One of the proponents, council member Schreuder, argued: "Maastricht will only benefit from the immediate construction of a tunnel." "The author of the 1958 Maastricht yearbook also referred to this issue: "it is the intention of the government to build a tunnel at this place in the future." In a recent brochure of the city of Maastricht a similar plan was suggested: pictures of the road immediately after its construction reveal that there was an intention to build a tunnel. Between the roads to and from the Geusselt traffic circle, space was set aside in order to realize the entrance of the tunnel at some point in the future." However, in retrospect, Rijkswaterstaat engineer Jamin disputed the assumption that a tunnel would be built at that time. He suggested that the confusion about the tunnel was due to the fact that 
many people failed to make a clear distinction between a tunnel and a lowered road, indicating that some articulated ideas about building a lowered highway with overpass junctions, not a tunnel."

Whercas a lot of space was reserved near the Geusselt traftic circle on the northern edge. at the southern edge of the urban section of Highway 75 much less space was set aside: the highway was in fact planned immediately adjacent to the first high-rise building of Maastricht, named the "Municipal Flat", that was built between 1948 and 1950 (see Figure 4.3)." The building. designed by city architect F.C.J. Dingemans (1905-1961) and consisting of ninety apartments, was built in response to the great shortage of homes in the post-World War Two era. From the beginning its design included elements that were seen as very modern at that time. such as elevators. central heating, and refuse chutes. "In general, it seems, the city"s leadership viewed this building and the other apartment buildings that were planned to line the urban stretch of the highway as quite "representative"; they were regarded showeases of the city's modernity, and, consequently, a lowered highway with slopes was basically not an option. It would take up too much space and obscure the buildings from view." Rijkswaterstat, by contrast, preferred a spacious design and a less conspicuous presence of buildings along the highway. It argued that having a more spacious layout of the highway "will prove to be the right opinion in the future." Notwithstanding this view, the apartment buildings were eventually placed relatively close to the highway.

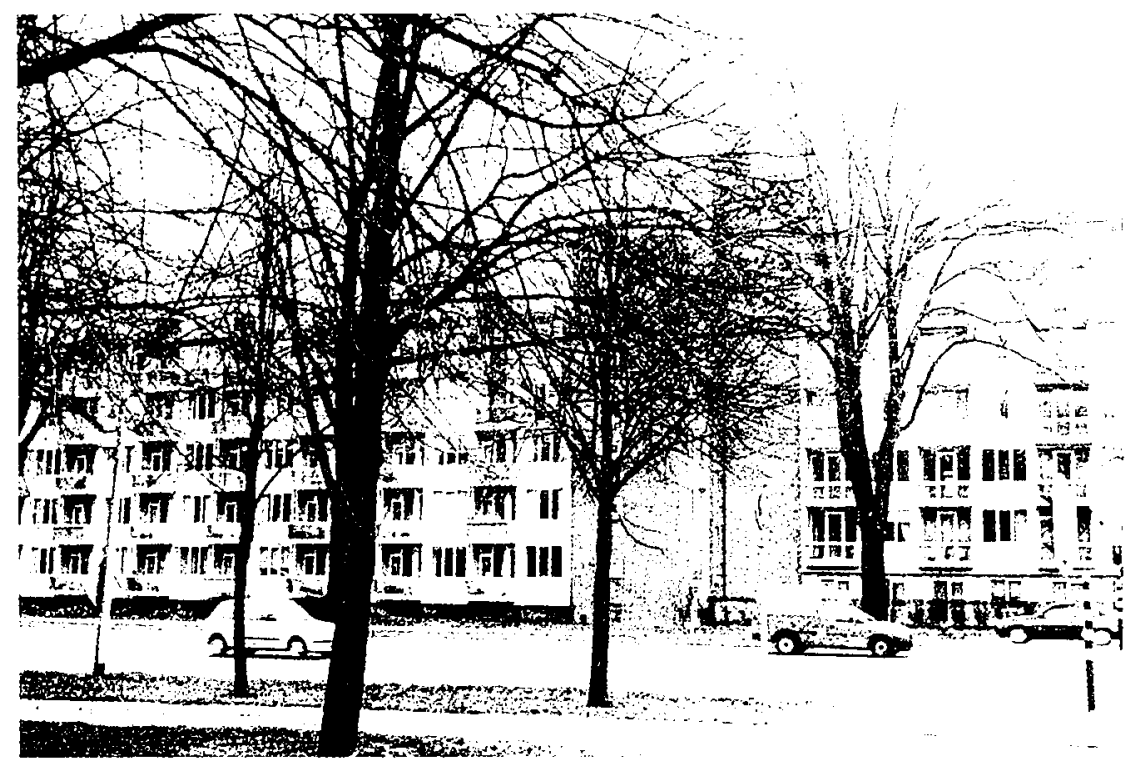

Figure 4.3: Municipal Flat (2000)

(1) Picture taken by A. Hommels

Those in charge of the decisions involving the highway's construction in the 1950s deliberately tried to keep various redesign options open, but, ironically perhaps, in later periods it turned out to be extremely difficult to radically deviate from the original design. The ultimate plan was based on a lot of considerations: opinions about 
traftic enginecring, views of the role of automobiles in cities, socio-economic considerations, town plaming motives, experiences in other Dutch cities, and earlier extension plans - all became integrated and embedded in the design of Highway 75. This underlines the importance of understanding the highway as part of a larger sociotechnical structure. consisting of the highway itself. the city's traffic circulation system, the apartment buildings surrounding it and the many ideas and implications involved in its design. As will become clear in the remainder of this chapter, many features that were built into the highway"s design maintained their obduracy for quite some time. It is important to identify the concrete circumstances that cause embeddedness to result in obduracy, but it is equally important to determine the moments at which obduracy might still have been avoided. At what points in the process did actors still have concrete opportunities for changing the highway's design? In the remainder of this chapter, I will analyze how, under the influence of new ideas and developments, the embedded sociotechnical structures of the urban section of Highway 75 became contested.

The effort to unbuild the urban section of Highway 75 can be divided into four periods that are each marked by a significant shift in the types of unbuilding activities that were undertaken. The first period began in the early 1970s when Rijkswaterstaat and the city sought to better integrate the highway into the overall urban traffic scheme by reconstructing the highway's main intersections, reconstructions which eventually took place between 1974 and 1978. I will argue that in this effort, the combination with existing local traffic practices and the overall town planning structure surrounding the highway, increased the difficulties of adapting the highway's design. The second phase covers the years between 1978 and 1982. when a Trajectory Study was done in which two redesign options played a major role: a tunnel and a diversion east of the city. This study caused decisions about the implementation of a possible solution to be postponed, thus triggering a new phase, lasting from 1982 until 1993. when various efforts focused on temporary measures. These efforts to improve the highway's design were frustrated in part by the highway's embeddedness in all sorts of legal regulations. Finally, the years between 1994 and 1998 once again reflect a more radical effort to reconstruct the highway, mainly because of the Trajectory/EIS Study that was initiated.

\section{Reconstructing the intersections (1974-1978)}

By the 1960s, town planning and urban road design had become increasingly linked in the Netherlands. In a 1965 article in Wetenschap en Samenleving (Science and Society). H.A.M.C. Dibbits underscored the significance of their integration. Specifically, he pointed to the difficulty of dealing with historically grown situations in towns, where buildings of cultural and historical importance could not be simply demolished to allow space for new roads. Dibbits also warned for the cumbersome nature of traffic arteries and suggested that in many situations it was impossible to fit them in afterwards." Although there seemed to be some agreement that old inner cities had to be preserved, many Dutch cities initiated large-scale reconstructions in the 1960s. This involved, among other things, new ring roads around downtown districts. 
as well as beltways around cities as a whole, and the paving over of canals to make space for cars." It was also deemed important, mainly for reasons of safety, to separate the various types of traffic. Thus city planners were faced with the challenge of putting in place two different systems side by side: one for motorized traffic (cars, buses) and one for slow traftic (pedestrians, bicyclists)."

The completion of the urban stretch of Highway 75 did not mute the debates about its design. Almost from the start, the residents of Maastricht began to voice their concen about structural flaws. Already by the carly 1960)s, it was obvious that the urban section of the highway was quite unsale. Particularly one of the main intersections, the Scharnerweg. secmed to baffle many car drivers, as evidenced by the large number of accidents that occurred at this site. The introduction of traffic lights at this intersection significantly improved the situation," but in time other reservations were put forward that had to do with the delays that resulted from the increase of local traffic and with the general unsafety of the highway. Moreover, complaints about the noise produced by the crowded highway grew louder, while concerns about its barrier function, dividing the city in two, resurfaced. Quite soon, then, the parties involved the Province of Limburg, the residents of Maastricht, the city leadership and Rijkswaterstaat - agreed that the highway's design had to be adapted more fundamentally.

The substantial social and cultural changes of the 1960s, including the explosive growth of mobility and the emergence of environmental concerns, had nourished the view that the highway was outdated. However, the articulation of new plans was complicated by the fact that meanwhile the highway had become embedded more solidly in the larger urban and (inter)national traffic system, as well as the overall town planning structure. Moreover, local user practices further limited the opportunities for adapting the road's design.

\section{The highway's integration in traffic systems and town plaming structures}

During the 1960s, the road had become more and more incorporated into the local and international traffic circulation network. In 1970, a cloverleaf at the Europaplein was constructed, situated at the southem tip of the highway's urban section. "From there on. the highway extended southward for some ten more kilometers before it fed into the Belgian highway system. The construction of this final stretch linked up Highway 75 with the international highway network. In addition, the highway's integration in the local traffic network was further consolidated when just to the west of the highway, near the Scharnerweg intersection, a tunnel was constructed, which facilitated a better flow from the eastern part of the city to the downtown district.

In the course of the 1970s, traffic on Highway 75 further increased. The authors of a 1974 Rijkswaterstaat report pointed out that the highway's urban section and the adjacent buildings were built in an era when no one anticipated serious traffic growth and traffic nuisance hardly was a factor." But meanwhile the capacity of the highway had proven insufficient, the road surface was in bad shape and the traffic lights regulation system was no longer up to date. As a result, the authors argued, a dangerous situation had arisen that was especially unacceptable to the people who lived nearby." 
Rijkswaterstaat and the city board decided to reconstruct the road in 1976. In August 1977, the Geusselt traffic circle was transformed into an intersection secured by traffic lights. According to Rijkswaterstaat, this adaptation was necessary to improve the flow of traffic and to avoid future congestion. One of the other goals of this reconstruction was to improve the safety of cyclists and pedestrians. According to representatives of the Province and road users, the changes were not implemented quickly enough. In 1977, the Province began to put more pressure on Rijkswaterstaat to improve the safety of the highway. Meanwhile. parents whose children attended the primary school near one of the intersections challenged the city board for not regulating the traffic lights very well." This poor regulation, they argued, had already caused many near accidents when children and parents were crossing the highway. To emphasize their protests, they blocked the highway for some time.

One of the main difficulties in the highway reconstruction process involved the Scharnerweg intersection. Rijkswaterstaat analyzed the various options and found that the intersection's main problems comprised its low capacity, its danger for pedestrians and other slow traffic, the high noise levels, and the continuous delays for public transportation when crossing the highway." The options that were mentioned earlier cropped up as solutions once again: an overpass junction or a level road junction in combination with a diversion east of Maastricht. In the choice between these redesign proposals, the integration of the highway in the larger infrastructure and traffic scheme of the city that had been established in the late 1950 s played a crucial role. Furthermore, user practice became an important consideration in the choice for redesign options. It turned out that the volume of local traffic on the urban section of the highway was larger than the volume of through traffic. As a result, the diversion was rejected because experts thought it would hardly reduce the density of traffic on the urban stretch of 75. Moreover, it was argued that planning this diversion would take up a lot of time and money. Similarly, the option of an overpass junction was believed to be extremely expensive. Besides, experts anticipated that the new bridge across the Maas River that was already planned, the Noorderbrug, would alleviate part of the congestion on 75 , so that an overpass junction at the Scharnerweg would, in effect, no longer be necessary.

The city leadership emphasized the importance of the urban highway stretch for local traffic circulation. In 1964, Van de Venne already claimed to be pleased the road did not function as a full-blown highway, because that diminished its barrier function as well. Moreover, he argued, the highway's current design allowed it to be in integral element of the ring road around Maastricht, in part because of the highway's multiple connections with the urban traffic network." The city leadership underscored the highway's significance for local traffic, specifically as access to the downtown district. If its integration into the local traffic network would be omitted, the downtown area would be much harder to reach by car. Therefore, the city argued, overpass junctions without easy connections to the local infrastructure of roads would be unacceptable. In this way, the view of the city leadership contributed to the obduracy of the existing design, including its connections to the inner city.

Another reason why it was difficult to reconstruct the Scharnerweg intersection had to do with its embeddedness in the larger town planning structure. In the 195()s, the city leadership deliberately opted for the highway's inclusion in a representative 
town planning structure. including modern apartment buildings. After the construction of these buildings along the highway it became increasingly difficult to implement changes. To the city board. a solution with overpass junctions was basically unaceeptable, because it would involve rigorous adaptations of the intersections and the demolition of buildings to find space for access roads and exits." The preservation of the apartment buildings and the wish not to spend much money on a solution played an important role for the city leadership. This illustrates that embeddedness has a distinct financial side to it: once urban structures have become embedded it can simply be very expensive to "unbuild" them.

As a result of these considerations, only ground level solutions were acceptable: the highway was slightly diverted westward. so it would be a little less close to the existing apartment buildings. This limited the noise somewhat, in particular for the residents of the Municipal apartment building. which was closest to the highway. Furthermore. Rijkswaterstaat installed a new traffic lights system. "Although the city board was not altogether satisfied with the reconstruction plans, they thought that doing nothing was worse: moreover. the new measures were considered to be only temporary." In June 1977, the reconstruction of the Scharnerweg intersection neared completion (see Figure 4.4). In 1978, the traffic lights were phased for $50 \mathrm{~km} / \mathrm{h}$ to ensure a fluid passage of cars through Maastricht.

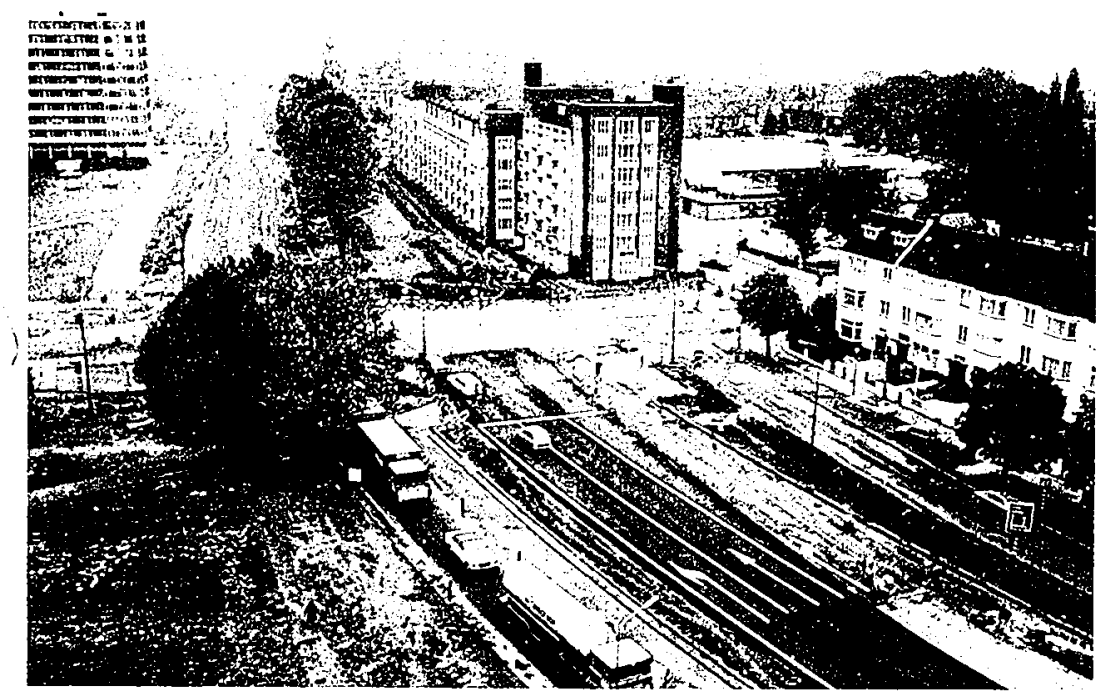

Figure 4.4: Reconstruction of the Scharnerweg intersection 1976

Source: Gemeentearchief Matastrich (1) Fotopersbureau Widdershoven

So far. I analyzed how the urban section of Highway 75 became embedded in larger traffic schemes, user practices and town planning structures, each factor further complicating the possibility of radical changes in the highway's design. As my analysis suggests, material factors alone could not account for the highway's obduracy. I demonstrated, for instance, how the commitment to existing town planning 
structures, financial arguments and user practices played a crucial role. Neither was it useful to explain the complexities of redesign with reference to the existence of dominant ways of thinking. At this stage. the actors did not rely on dominant technological frames that guided their interactions and ways of thinking. The redesign options, in other words, were not limited by a particularly high or low inclusion of actors in a specific technological frame. This also explains that the sharp conflicts that frequently result from strong commitments to technological frames, as was the case in the Utrecht City Project, were hardly a factor. The highway's resistance to change at this stage of the process can best be explained, I believe, by the specific forms of embeddedness I described.

To further illustrate the usefulness of "embeddedness" as an explanation for obduracy. I will now make a paradoxical move by using the concept to explain the obduracy of a technology that is not even implemented yet. I will argue that particular solutions, as in this case the tunnel option. can become embedded in urban. regional and national policies. as well as in the ideals and activities of citizens and politicians. before they even become a physical reality. Thus embedded. the tunnel. while nonexistent. had important effects on the unbuilding process. Although I will primarily focus on what 1 identified as the second period in my account, the phase of the Trajectory Study (1978-1982), I will also discuss the role of the tunnel option prior to this period as well as afterward, when this idea became more and more integrated in various relevant urban spatial policies.

\section{Trajectory Study (1978-1982)}

\section{Embeddedness of the tunnel option in spatial policies, ideals and expectations}

By the 1970s, policy makers' opinions about the location of highways in relation to cities had become more pronounced: highways should preferably not be led through cities (where they cause all kinds of environmental, safety and liveability problems). but around them. This shift took place in the context of a more general change of opinion among town planners, policy makers and citizens about large-scale urban interventions in the 1970s." Whereas in the 1960s, increased automobile traffic often served as a legitimization of drastic solutions, including major interventions in infrastructure (filling in canals) and urban districts (demolishing old towns) that had been around for centuries, this was no longer accepted in the 1970s. Local actions groups increasingly voiced loud protests against huge urban redesign projects.

In the late 1970 s. three policy reports mentioned the possibility of a diversion of the urban section of Highway 75 (now named A2) around Maastricht. The Province of Limburg proposed the diversion as an option. but stated that putting in overpass junctions at the present trajectory still had priority. The national govermment's "Structural Plan for Traffic and Transportation" (Structuurschema Verkeer en Vervoer, 1976). a general planning report that summarized the most important policies of the Ministry of Transportation. also referred to a diversion of the highway in Matastricht, to be completed in the $1990 \mathrm{~s}$. The report argued that highways of the main national network should bypass urban areas. wather than go through them, because the absence of large flows of traffic in cities would improve urban living environments and reduce 
risks such as those associated with the transportation of hazardous materials.

These policy reports had a concrete effect for Maastricht in that they caused the city leadership to decide to set aside a strip of land that in the future might be used for the diverted highway east of the city. As a consequence, this area could no longer be used for other extension plans of the city. The municipal Structural Plan mentioned the possibility of a diversion of the highway east of Maastricht, but it also anticipated urban expansion at the eastern edge of the city. Although there was not very much (international) through traffic on Maastricht's highway yet, the city board considered the prospect of heavy trucks passing through the city 24 hours a day as unacceptable." Because traffic was expected to go up and international standards for the design of highways were ever more tight, the city board felt pressured to investigate the possibilities for adaptation of the existing trajectory or its diversion.

After World War Two, Maastricht, like many other Dutch cities, suffered from lack of space and scarcity of decent housing. In 1962, the director of Public Works, $V$ an de Venne, had already proposed the annexation of neighboring villages, to establish a "Greater Maastricht". The planning effort aimed at the city's expansion was affected, of course, by the uncertainty about the highway's future. Although the mere mention in policy documents of a diversion on the eastern edge of the city implied a claim on this area, other actors advanced competing proposals for this area. These claims involved urban expansion, nature reserves and water procurement areas. as well as other possible road connections east of Maastricht."

Because of the projected traffic growth, changed political and urban spatial policies, and international regulatory adaptations, discussions about the highway's design resurfaced. It was decided to study the various trajectory and design alternatives so that the city board could make an informed decision on how to use the available land. The project team "E9 and Maastricht," that was going to be in charge of the Trajectory Study, was formally established on 16 June 1978 by the mayor and city board of Maastricht and the chief engineer and director of Rijkswaterstat.

This team studied two design variants and a number of subvariants. One variant started from the existing trajectory of the highway and explored the closed tunnel option, the lowered highway option, or the lowered highway with acoustic fencing option. A distinction was made between designs that either did or did not integrate the Scharnerweg intersection. The second variant explored possible diversion trajectories along the eastern edge of Maastricht (see Figure 4.5).

As pointed out above, the idea of a tumnel to resolve the problems associated with the urban stretch of the highway was mentioned already in the late 1950 s - in the annals of the city as well as in the minutes of a city council meeting. In the 1970s, when Rijkswaterstaat and the city were thinking about reconstructing the highway's intersections, the idea of a tumnel turned up again. Residents of the nearby apartment buildings established an action committee, called "E-9 underground" (E-9 ondergronds), in which members of environmental action groups also participated. ${ }^{5 *}$ In a letter to the city council, the committee argued that the plans for reconstructing the Scharnerweg intersection were unacceptable. In their view, the planned reconstruction would not contribute to a reduction of the noise produced by the highway. They claimed that a tunnel could be built without demolishing any houses, while at the same time keeping all the existing connections of the highway to the local traffic network in 
place."' Moreover, they argued that the proposed modifications would make future adaptations increasingly difficult."

Although a tunnel would be more expensive than the diversion, the city's leadership also preferred a closed tunnel. By the early 1980s, a connection to the Scharnerweg was no longer deemed necessary by the city": "The only right solution in our view is a tunnel at the location of the present trajectory. especially now that its technical feasibility has been established." "Since then, the city's leadership has been fairly consistent in its preference for a closed tunnel." According to P. Jansen, a city traffic engineer, the city opposed all lowered road variants because none of them could sufficiently diminish the various forms of environmental damage produced by the urban highway stretch." Only the closed tunnel option would meet the environmental standards (those regarding noise pollution in particular), while it also significantly reduced the highway's barrier function, something the city strongly supported. ${ }^{\text {(x) }}$

The city board rejected a diversion east of the city. A diverted highway along the city's eastern edge would form a barrier as well and would completely do away with the city's smooth transition into the surrounding landscape." The diversion would negatively affect agriculture. drinking water supplies, recreation and the living enviromment of the residents of the eastern districts. Moreover, a diversion would conflict with the then prevalent "city border philosophy" of the city's leadership that aimed at a gradual transition from city to countryside." This philosophy had become increasingly important and was closely linked up with the city's identity. Former city manager Ad Lutters commented that in the cyes of the city leadership "the eastern border has been a sacrosanct fringe that should not be touched," a view that almost became "a kind of dogma" over the years. Situated in a river valley and surrounded by rolling green hills that contain the characteristic yellow marlstone. Maastricht has always cherished its unique geography."

Apart from the traffic and cost arguments put forward in the discussions about the reconstruction of the intersections in the mid-1970s, environmental arguments (landscape, water supplies, vistas) and the importance of a gradual transition from city to countryside were now advanced to discredit the diversion option. In the opinion of both the city leadership and the residents the city's eastern border was rigid - it should not be tampered with. 


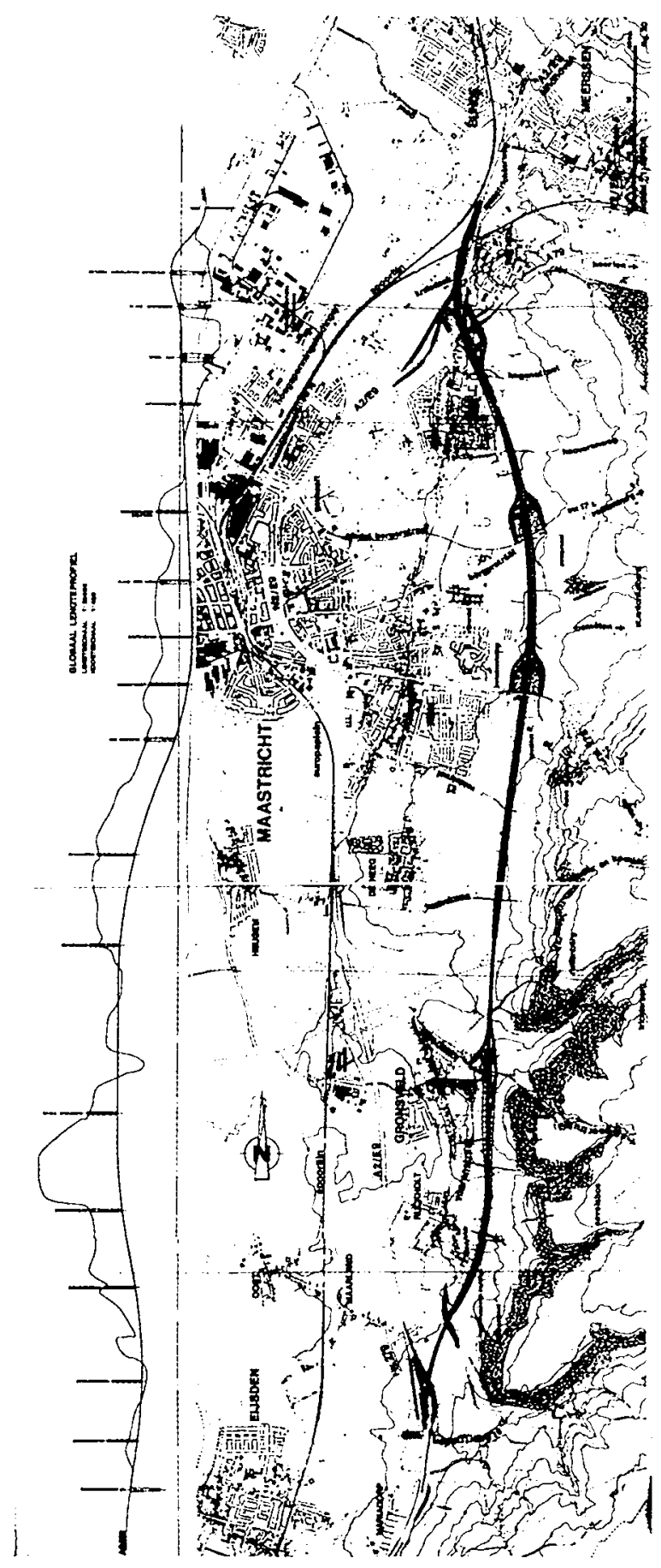

Figure 4.5: Diversion east of Maastricht

Source: Rijkswaterstatat 1979 
The idea of a diversion had nevertheless played an important role in Rijkswaterstaat's way of thinking for a long time; it had already been considered - and abandoned - twice: before World War Two and in the mid 1970s." Although the amount of traffic did not necessitate measures at that time, Rijkswaterstaat opted for a diversion around the city for reasons related to traffic growth, traffic safety and the living environment. In Rijkswaterstatat's view, safety was paramount and therefore it did not favor a closed tunnel: the transportation of hazardous goods through tunnels was widely considered to be too risky. Furthermore. its wish to transform the urban section of the highway into a "real" highway could be easier realized by opting for a diverted trajectory. In general, highway engineers find it easier to build highways in relatively open spaces than in built-up urban environments, where existing town planning structures seriously limit the available design options." A Rijkswaterstaat memo of April 1978 suggests that at that time the decision process was primarily geared toward the diversion variant rather than the existing trajectory." Even though this preference was denied in an earlier letter to city board member Dols of 27 January 1978," in retrospect Jamin, a highway engineer involved in the design process, cmphasized the importance of the diversion altenative for Rijkswaterstaat:

\begin{abstract}
At that time, we were not at all working on a road trajectory that went through the city. We were only studying alternatives outside the city. At the very last moment, we received a directive from The Hague: 'You should also make a plan for a highway that cuts through the city.' There were. however. only broad outlines for such a plan, while the diversion option, by contrast, was thoroughly investigated. including zoning schemes."
\end{abstract}

In 1981, the residents of Maastricht were publicly consulted about the proposed diversion. A majority appeared to be against the diversion, whereas most considered a tunnel below the existing trajectory the best solution. ${ }^{75}$ According to the residents of the eastern city districts, the diversion of the highway would locally devastate the environment. Yet the residents of the apartment buildings along the existing highway viewed their situation as "unbearable". The smell of exhaust fumes and traffic noise made their lives utterly miserable. Remarkably, perhaps, the majority of them also viewed a tunnel as the best solution. The old highway would then become superfluous. they argued, and should be transformed into a green area or park."

The Council for Water Works (Raad van de Waterstaat) had to advise the Minister of Transportation about the Trajectory Study. They concluded that:

Reconstruction of the present passage through Maastricht is. when taking into account nearly all aspects, more attractive than the construction of a diversion around the cily.

On 13 January 1982, the Minister of Transportation, H.J. Zeevalking (a member of the liberal democratic party D'66), decided in favor of the trajectory through the city. He did not say when the solution should be implemented, nor did he stipulate which of the three tunnel options should be built - a closed tunnel, an open tunnel, or a semi-closed tunnel with acoustic fencing. ${ }^{7 \times}$ Unambiguously, however, the Minister stated that a 
diversion was not a good option."

The hesitation to build a tumnel immediately can be explained by a number of interrelated cultural, historical. economic and political factors. In 1982 there basically was no congestion on the urban section of the highway. The oil crises of the 1970s had culminated in economic recession by the early 1980s. This, in turn. had diminished the growth of traffic, thereby decreasing the need for immediate action. "Moreover, in the 1970s. Dutch people had become more aware of envirommental problems; automobile usage was increasingly criticized for its contribution to air pollution and the depletion of fossil fuels. Govermmental transportation policies became more focused on reducing the number of cars. In addition. due to the then current noise regulation standards and tight budgets, full realization of the tunnel within a short time span could not have been possible." Furthermore, the problems of Maastricht's highway infrastructure were considered minor in comparison to those in the more densely populated western part of the Netherlands. Finally, at that time Maastricht and the Province of Limburg simply failed to have a strong highway lobby in The Hague. the seat of the national government."

After the 1982 decision of the Minister, the diversion option stopped playing a role: future alternatives would be defined in line with the idea of a tunnel and were limited to a reconstruction of the existing trajectory. The decision has since become more fully integrated in various municipal policies; as a result, a tumnel basically became a must in the eyes of the city. Clearly, the Minister's decision contributed to the tunnel's further embeddedness in the city's plans and policies.

After 1982, the idea of a tunnel became more and more part of the expectations and ideals of residents and local politicians alike. Rijkswaterstaat and the city began to work on several tunnel variants in the Working Group Tunnel Design that was established in 1989." For a while, the city strongly opted for an expensive drilled tunnel, since this was seen as the only possibility to avoid large-scale demolition. In the early 1990s, local real estate agents sold houses in nearby neighborhoods claiming that the city highway would soon disappear in a tunnel with the 'old' highway transformed into a city park. Residents of Maastricht also unfolded initiatives aimed at developing tunnel plans. In the mid 1990s, local town planner René Daniels, director of Buro 5, proposed a tumnel design, to be developed in collaboration with project developer HBG Vastgoed and an engineering business. Their provocative plan (see Figure 4.6) played an important psychological role in the overall planning process. ${ }^{x+1}$ According to Daniels, the plan was largely in accordance with the city's viewpoints in the 1990s; the soon-to-be former highway, for instance, was designed as a boulevard with trees. Moreover, demolition of apartment buildings would not be necessary in Daniels's solution." Although Armand Cremers, the city board member in charge of traffic issues at that time, liked the scale model of the plan very much, the plan was never seriously considered as a definite solution by the city. Looking back, Cremers argued that the plan turned up "too early" in the process of thinking about solutions and that it was "too concrete". He suggested the solution did not fit in the existing town planning structure and failed to solve the financial problems."

It is perhaps surprising that the tunnel option, despite its popularity with the residents and leadership of Maastricht, was not thoroughly studied before the $1980 \mathrm{~s}$. Since then, however, the idea of a tunnel has played a central role in the expectations 
and ideals of those immediately involved. In time, the tunnel idea acquired robustness: it became difficult to neglect in the unbuilding process. Obviously, its obduracy had no material component, for the tunnel did not exist as a reality yet. The tunnel grew obdurate, in the first place, because it became linked with expectations and ideals of residents: already in 1958, the tunnel idea was mentioned. That same year, council members proposed a tunnel as the preferred future design of the urban highway stretch. In the 1970s, residents who were represented in the "E-9 underground" action committee made a strong case in favor of a closed tunnel. The public reactions to the 1980 Trajectory Study showed that residents preferred a closed tunnel with a park on top of it. Most recently, the tunnel turned up in a new citizens' initiative: Buro 5 designed a tunnel and visualized it in a scale model. Second, the idea of a tunnel acquired more robustness when it becime integrated in municipal policies and activities: the city established a Working Group, particularly aimed at designing tunnel variants. After the decision of the Minister in 1982, the idea of a tunnel in Maastricht became further integrated in local plans and policies."

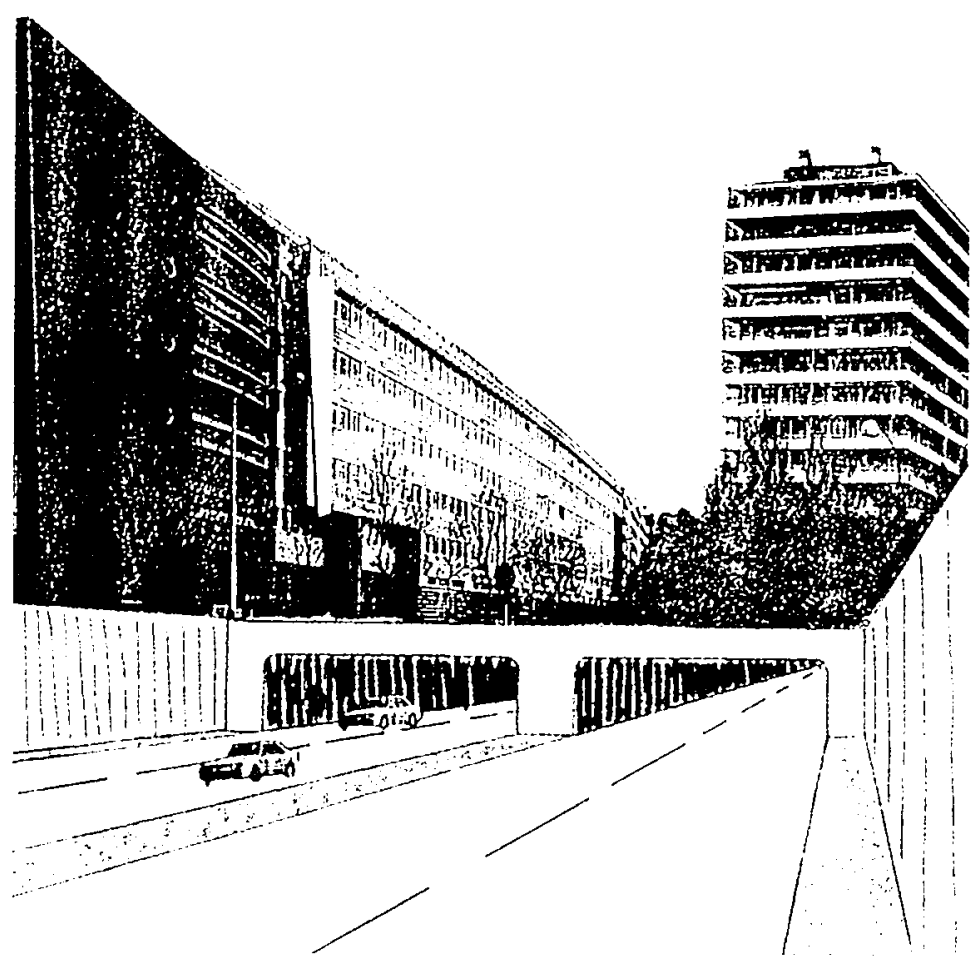

Figure 4.6: "Hide-a-way": Artist impression of tunnel plan for the urban highway through Maastricht by Buro 5

(1) HBG Vastgoed and Buro 5 Maastricht 


\section{Temporary measures (1982-1993)}

\section{The highwav's embeddedness in legal regulations}

As a result of the Minister's 1982 decision, the diversion alternative stopped being considered. Although the tunnel had become the only serious option, it nevertheless receded to the background because its implementation was postponed. The tumnel was increasingly seen as a project that would be realized in some distant future and this opened up debates about short-term measures, for, after all. most of the highway's problems did not simply vanish. Because actual tunnel construction was not planned to begin before the 1990s, temporary measures were considered necessary to lessen the nuisance caused by the highway. The decade of the 1980s was one in which highway design in urban areas in general, and the urban stretch of the highway in Maastricht in particular, became increasingly tied to legal standards and regulations. This made it more difficult to make major adaptations in the highway's design. During that period, environmental laws on noise and toxic emissions gradually toughened." In Marastricht, a range of measures aimed at reducing the traffic noise for the nearby apartment buildings (the so-called "milieubouwplan") was executed in 1982." In 1983, residents protested the sound batfles that were built, claiming that they made the highway less sale:

As long as we have no tunnel with overpass junctions, the risk of aceidents remains.

All temporary measures you take are palliatives. Much money has been spent on reconstructions already. but the highway hardly becime safer."

Residents vehemently tried to stop the building of a wall to lower the traffic noise," even comparing it to the Berlin Wall (see Figure 4.7)." The protests, however, led only to a few adaptations in its design. Three years after the acoustic fencing was put in place, the residents of the Oranjeplein apartment buildings were still all but satisfied. They argued that the wall isolated the neighborhood behind it, impoverishing the area. Moreover, traflic safety had gone down and traffic noise had aggravated rather than diminished, according to the residents."

It was clear, however, that the reconstruction of the highway in Maastricht was not a large priority on the national agenda. In the Second Structural Plan for Traffic and Transportation (Tweede Structuurschema Verkeer en Vervoer, 1988), the A2 was labeled a "main transport axis" instead of a "hinterland connection." As such, it was given lower priority, which meant that no budget was set aside for its reconstruction." The city board, the Province of Limburg and the Chamber of Commerce were worried about this and decided to join forces in their search for temporary solutions. 


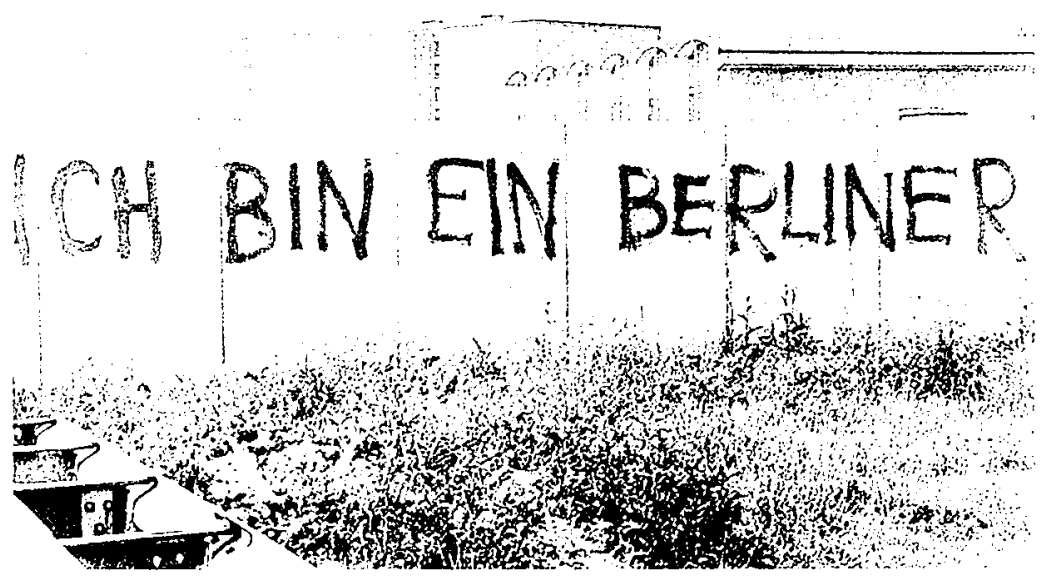

Figure 4.7: Protest against sound baffles, President Rooseveltaan (1983)

Source: Gemeentearchief Matastricht (i) A. Werker

On 12 July 1991, a Working Group for Temporary Measures was established, consisting of members of the city, Rijkswaterstaat, the Province of Limburg and the Chamber of Commerce. Since it was expected that a tunnel could not be realized before 2000, temporary measures were seriously studied. These involved the adaptation of the traffic regulation scheme, adaptation of the Scharnerweg intersection, and broadening the highway. Since an increase of traffic was expected. the measures were mainly geared towards avoiding congestion.

In this phase a new alternative solution emerged, the so-called "solution of Liège". This meant that the local roads would pass above the highway at ground floor level (see Figure 4.8). The Chamber of Commerce of Limburg, representing the interests of the regional businesses and companies, advocated this solution since it would be a quick solution that could be built within short term. For the Chamber of Commerce, the improvement of the accessibility of Maastricht and the region was the most important goal to be achieved. Quick, provisional solutions, it believed, should be favored over long-term solutions." However. some of the solutions proposed. e.g. the solution of Ličge and a widening of the road to six lanes, were not possible becatse of the 1979 Noise Abatement Act (Wet Geluidhinder). This Act put limits to the amount of noise produced in specific "noise zones." Within such a zone, for instance. houses can only be built if the norm of $50 \mathrm{~dB}$ is not exceeded. In urban reconstruction projects the norms are somewhat less strict." Paradoxically, the Noise Abatement Act served both as an instigator of change and as a conserving force. On the one hand, it enabled taking measures in zones in which the noise levels were too high, but, on the other hand, it prevented implementing new building or reconstruction options in other cases, thus contributing to the obduracy of the existing structures in 
those areas.

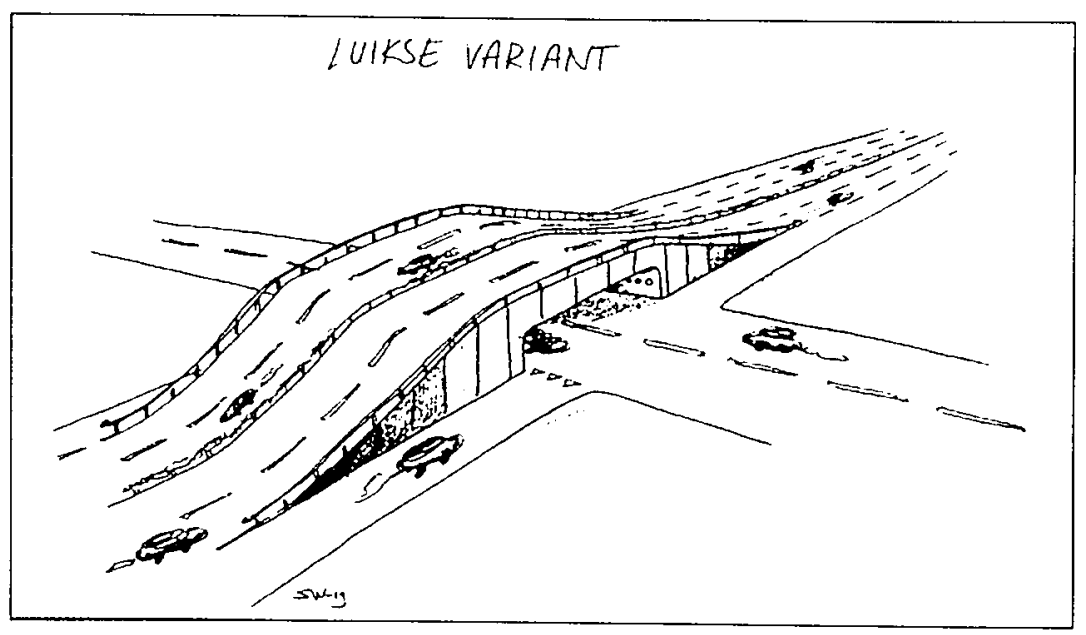

Figure 4.8: Solution of Liège (reversed)

Source: Pol \& Nigele (1996) (1) Beeldleveranciers Amsterdam

In 1992, the European Commission issued a directive on environmental impact assessment, making a so-called Environmental Impact Statement, or EIS, mandatory for highwaly construction. Because the 1982 decision on the urban highway section in Maastricht had not yet been implemented, this new procedure also applied to that decision." Moreover, the 1993 Trajectory Law" stipulated that the 1982 decision had expired because it had not been implemented within a ten-year time span. Thus, new laws and regulations had caught up with the earlier decision to change the highway's design. Whereas the implementation of temporary measures did not require an EIS procedure, an adaptation of the local zoning scheme (defined by law) would be necessary. In a zoning scheme the width of the urban highway was determined. ${ }^{\text {tin }}$ Considering a substantial broadening of the highway as one of the measures to be taken, an adaptation of the local zoning scheme would thus be obliged. In the Netherlands, zoning schemes are important instruments in spatial planning. They determine for which purpose real estate can be used and what can be built in specific areas and how one should build. Over the years, environmental standards have become integrated into zoning schemes. Zoning schemes have strict norms on exhaust fumes, noise pollution and levels of soil, water and air pollution. ${ }^{101}$ Adapting the zoning scheme was not considered an option according to Henk Schroten, at that time general director of Rijkswaterstatat. He did not anticipate the implementation of a final solution in the near future."' In this way, the highway's legal embeddedness in a specific zoning scheme contributed to the obduracy of the existing highway design.

Rijkswaterstaat thus proposed not to start with carrying out the suggested temporary measures. Making a general plan and the start of a planning procedure would raise expectations that Rijkswaterstaat would not be able to meet on a shortterm basis. In the Second Structural Plan for Traffic and Transportation, the urban 
highway section of Maastricht was mentioned as a project that would be executed after 2010." Limburg's Rijkswaterstaat Department proposed to start an EIS procedure. This was considered to be less risky than a new zoning scheme procedure on the basis of the trajectory decision of 1982, since a new EIS study would incorporate prevailing laws, measures and opinions. ${ }^{105}$

The developments during this phase demonstrate how new and existing judicial regulations maly form an important source of contention in processes of urban change. These legal issues also contribute to obduracy. When existing town planning structures no longer conform to new judicial regulations, adaptations have to be made and earlier redesign decisions may be nullified. New redesign proposals have to conform to existing regulations as became clear when the Chamber of Commerce proposed its plans for the solution of Liège. One of the reasons for starting a new EIS study was that a better match between recently developed regulations, opinions and laws and new design proposals could be achieved. Furthermore, my discussion suggests how the embeddedness of urban structures in existing judicial regulations, such as zoning schemes, can contribute to their obduracy.

\section{Trajectory/EIS Study (1994-1998)}

In December 1995, a first basic report outlined the main problems of the urban section of the highway that cuts through Maastricht. The report identified three targets of the Trajectory/EIS Study: to ease traffic circulation (avoid congestion), to enhance the quality of life of those living near the highway (less noise, smells and so forth) and to improve traffic safety. The initial report described the various alternative designs that would be investigated in the study. ${ }^{\mid k,}$ In 1996, the Rijkswaterstaat Department of Limburg commissioned the national Engineering Department (Bouwdienst) of Rijkswaterstaat to execute a new Trajectory/EIS study. Two formal groups were established in which both the city and Rijkswaterstaat participated: a technical group and a management group.

At this stage, Rijkswaterstaat acknowledged that some of the alternative designs proposed earlier were no longer feasible. Since 1982, all spatial policies of both the city and the Province of Limburg departed from the trajectory decision that had favored the existing trajectory of the highway." The city board added that residents still widely supported the 1982 solution as well. ${ }^{\prime \prime \prime}$ This preference for the existing trajectory had thus more or less become a given in the city's thinking. The minutes of a city council meeting showed that all local political parties (still) opposed a diversion cast of Maastricht, because the landscape had to be preserved at all cost and a diversion would not necessarily solve all the traffic problems. According to the city council, the 1982 decision continued to be a sound one and the arguments that were put forward at that time were still considered equally valid, if not more so. "'n' Evidently, the city"s point of view, in which the ideal of a tunnel and the city border philosophy figured prominently, had basically undergone no changes since the early 1980s. In other words, the existing highway trajectory and the tunnel option had acquired obduracy because of their embeddedness in the 1982 governmental decision, subsequent municipal and provincial policies, and the continued popular support. 
Having considered the various forms of embeddedness of Maastricht's highway as an explanation for the difficulties involved in the effort to change the highway's design. I will now discuss and evaluate two major strategies of dealing with embeddedness. Which strategies did the actors employ in their struggle with embedded urban structures? During the phase of the Trajectory/EIS Study two ways of addressing the embedded structures of the urban highway can be distinguished: one in which this embeddedness was deliberately, albeit temporarily, distegarded by assuming an almost infinite malleability (the Infralab procedure), and one in which an explicit confrontation with the embedded structures was sought the Design Workplace). To what extent can these strategies be considered successes?

\section{Disregarding embeddedness: The Infralab procedure}

Despite the preferences of the city, Rijkswaterstaat tried to broaden the redesign options by restarting the discussion and proposing a number of alternative designs. For example, it once again considered the diversion of the highway along the eastern edge of Maastricht as one of the alternative solutions. The other option was a reconstruction of the existing highway trajectory. Both options could be designed as either a highway $(120 \mathrm{~km} / \mathrm{h})$ or a normal road $(80 \mathrm{~km} / \mathrm{h})$. Besides, an EIS-procedure required that the situation of taking no measures at all had to be investigated and the option of keeping the existing situation as it is plus a number of additional measures to reduce congestion. The highway itself could be designed below surface level, at surface level or above surface level." Finally, the "most environmentally friendly" alternative had to be studied as well as the option of a drilled tunnel. These alternatives were all discussed in the first report."'

The decision process at this stage was accompanied by a relatively new procedure, based on the "Infralab" methodology"? This methodology was introduced by Rijkswaterstatat in 1994 and basically consists of three steps. First, different users and stakeholders are invited to define the main problems in relation to the infrastructure project involved. Next, stakeholders, users and experts in the field of highway design and civil engineering come together to think about creative solutions to the problems defined in step one. The third and final step involves the selection of the most promising solution by experts and politicians in charge of the issuc.

Rijkswaterstaat invited members of different groups that had a stake in the urban highway's redesign. Thus, residents, automobile drivers and representatives of the Chamber of Commerce, the city of Maastricht, cyclists interest groups, Province of Limburg, the General Dutch Automobile Association (ANWB), and local action groups all met to discuss their view of the main problems and to reflect on solutions. ${ }^{11:}$ For the ANWB, a good traffic circulation system without congestion was the most important goal to be achieved, while it also felt that through traffic should not be hindered by local traffic." The action committee "No East Variant for the A2!" (Geen Oosttracé voor de A2!), consisting mainly of residents of the eastern districts of Maastricht, wanted to prevent highway construction east of Maastricht. It argued that the quality of life in the eastern part of Mastricht would considerably decrease as a result of a diverted highway while the landscape and ecology would suffer as well. One of its arguments, for instance, was that the east variant might destroy the natural habitat of a rare species of hamster (the "Korenwolf"), which is only found in that part 
of the Netherlands." Other groups specifically focused on the interests of slow traffic participants, such as pedestrians or cyclists.

Residents of the nearby apartment buildings were also invited. Since 1966. Mrs. O. Kars has been living in one of the apartment buildings near the highway. Kars explained that the highway was relatively quict in the late 1960 s and that it was more like a local. two-lane road: "There were no pedestrian crossings... But it was so quiet that I could cross the road easily. No problem at all. During summer heat waves, I slept on the balcony. Now this would be absolutely impossible." "Noise pollution was the biggest problem for the residents of the lats: "It is impossible to open a window because it then becomes impossible to have a conversation or to listen to the radio or TV." "Despite these problems that gradually aggravated while she has been living near the highway, Kars did not want to move. As she pointed out: "I do not like to move. It is such a comfortable flat, and it is impossible at the moment to obtain a flat with such a spacious living-room and hallway for the same price... Therefore, I stay put, as do the other people who live in these apartment buildings." ${ }^{11 *}$ According to Kars, the apartments provide housing to elderly people in particular, many of whom have lived there for a long time and do not want to move anymore.

In 1995, the residents of the apartment buildings near the highway established the "Interest Group City Highway" (Belangengroep Stadstraverse). "1" According to Kars, one of the members of this group, the residents favor a tunnel with a narrow opening, a local road on top of it and measures to diminish the quantity of through traffic at the Scharnerweg intersection. Remarkably, some even prefer reconstruction of the existing highway over a diversion. As Kars explained: "The trajectory is in place, it simply is there. It should be used. And it should be used in a way that is least harmful to the residents.",21

Interestingly, the Infralab methodology is based on the idea of putting existing solutions and ways of thinking between brackets in order to allow a new creative process to start from scratch. ${ }^{12}$ By temporarily disregarding the embeddedness of the urban highway, and by stimulating the generation of ingenuous solutions, the participants were no longer limited by constraints and could thus come up with various radical alternatives. The Infralab method tries to circumvent all the types of obduracy discussed in this dissertation, not only embeddedness. Dominant ways of thinking, for instance, related to design solutions that frequently turn up in the process, had to be ignored as much as possible. In this case, the alternatives originally defined in the first report, such as the diversion and the tumnel, had to be set aside temporarily." The fact that users without professional training in highway engineering are involved in the procedure implies that many aspects related to embeddedness and dominant ways of thinking (such as the technical criteria for the design of highways and the most appropriate curves) are not automatically taken into account when developing new solutions. According to one of the initiators of the Infralab method, Ad de Rooij, deeply rooted traditions, such as the technocratic approach in policy making and thinking in terms of measures based on strictly scientific reasoning, also need to be bracketed off in the Infralab process.

This approach may produce sweeping proposals for reconfiguration and surprisingly fresh visions. In total 18 new concepts were developed by means of the Infralab procedure in Maastricht. These included, for instance, a tunnel below the 
Maas River, an elevated road, a new ring road anound Maastricht, a combination of rail and road infrastructure in one tumnel, and so forth. As an outcome of the Infralab sessions in Maastricht, a completely new, alternative highway trajectory was taken into consideration: the so-called "minor" trajectory (spiegeltracé). This trajectory consisted of a tunnel below the neighborhood of Wittevrouwenveld that formed the mirror image of the existing trajectory. That radically new solutions were proposed in the Infralab process can be partly explained by the fact that the participants did not have to take factors into account that nomally cause obduracy. As we have seen in this chapter as well as in the previous one, it can be very difficult during a planning process to set aside dominant ways of thinking. existing solutions, laws, policies, personal stakes, assumptions about financial feasibility of solutions or technical design criteria. These factors all play a crucial role in the constitution of obduracy.

Despite the radically new views produced by this procedure, obduracy is hard to bypass. In general it appears to be very difficult for Infralab participants to be genuinely creative. Hans Smeekes, facilitator and co-inventor of the Infralab procedure, explains that this particularly applies to Rijkswaterstat employees because they know so much and have so much experience that they "must force themselves to abstain from saying too soon: that has already been tried once, that is impossible because..." The Rijkswaterstaat engineers have trouble ignoring their training and expertise in highway design. Infralab employees Hank Kune and Frank van Erkel observe that experts in particular are no longer sensitive to new insights and more radical possibilities for change. As a result,

\begin{abstract}
the interpretation of the process and the solutions still takes place within the old' frameworks. Furthermore, participants of creative processes ... have difficulties to get rid of their own pet subjects. This tends to be the case more often when the group is more homogeneous (more people of Rijkswaterstate).
\end{abstract}

In the course of the Infralab procedure's application in Maastricht, gradually more conditions were set, thus reducing the available elbowroom. The experts and politicians that had to choose among the most promising alternatives had to apply four standards to the new solutions: (1) the solutions may not result in an impairment of monuments or buildings of architectural or historical value in the city of Maastricht; (2) the solutions may not result in unacceptable congestion on the major north-south route that cuts through the city; (3) the solution should result in an improved accessibility of the Maastricht region; (4) the solutions should result in an improvement of the quality of life along the highway without transferring problems to another location. 127 These standards, of course, reflect the highway's embeddedness in the larger town planning structure and traffic scheme.

A second Infralab procedure was initiated to discuss the most promising outcomes of the first. The aim of the second procedure was to discuss the problems that would be the result of the design solutions chosen in the first Infralab procedure and to find solutions to these problems. "The second procedure was thus less "open" than the first. One of the solutions that came out of the first procedure, the mirror trajectory, received specific attention during these sessions. But when this solution was eventually confronted with the existing town planning structure it was rejected: the 
mirror trajectory proved hard to fit into the existing urban configuration. The projected tunnel, for example, could have hardly avoided a nearby cemetery. Most highway engineers and planners consider respecting the integrity of graveyards an unwritten rule. Rijkswaterstaat generally tries to keep a distance of at least one hundred meters from existing cemeteries when planning new trajectories. ${ }^{124}$ Moreover, the residents of the Wittevrouwenveld neighborhood raised protests against the mirror trajectory. The highway"s project manager at Rijkswaterstaat Limburg. Frans Hendrikx, remarked that Wittevrouwenveld used to be a socially disadvantaged area. Much effort had already been put in its upgrading and radical changes might easily disrupt its positive development, Hendrikx suggested. '"it The mirror trajectory option, then, ran up against a graveyard and a social revitalization program, major factors that turned it into a strongly embedded option after all.

Other design solutions were also rejected during the process when confronted with the existing urban structures. Highway engineers considered the solution of a drilled tumnel as "unrealistic." since this option depended on radical spatial and technological adaptations. Due to the existing highway trajectory's location in an area with high ground water levels, the upward pressure of the ground water required a drilled tunnel to be built deep into the soil. This would severely complicate making connections to other roads. In comparison to conventional tunnels, the cost would be enormous. Other solutions were also abandoned for financial reasons. It would be 100 expensive, for example, to replace or remove underground wiring and cables. Some options were rejected because they would not be able to accommodate future traffic growth, or because they contradicted the goal of improving the quality of life for those living near the highway's trajectory."

Thus, when all the creative potential of the Infralab procedure had been used up and each of the alternatives had been confronted with the common sense reality of special interest, finances, embedded town planning structures and Rijkswaterstaat engineers, the newly invented designs had to be rejected one by one after all. However, this is no reason to argue, I believe, that the Infralab has not been successful. Although the overall procedure rests in part on an imaginary situation of unlimited freedom, it can result in the articulation of new and creative solutions that would not have come up in a process in which users and interest groups are not given a voice. On the other hand, the procedure has a number of obvious disadvantages. First of all, new, creative solutions that are proposed during the Infralab process may lead to protests or even social unrest. The inhabitants of the Wittevrouwenveld neighborhood saw themselves confronted with a solution that, if implemented, would have deeply affected the quality of life in their neighborhood. Second, the process may raise false expectations among the participants. Residents and users may expect that their radical proposals will indeed be implemented, while in most cases this will not be feasible at all. Eventually, the application of the Infralab procedure has to acknowledge the obduracy of urban sociotechnology.

\section{Acknowledging embeddedness: The Design Workplace}

The opposite strategy, acknowledging embeddedness in the redesign process from the start, characterizes the Design Workplace approach. A Design Workplace consisting of representatives of Rijkswaterstaat's engineering department, Rijkswaterstaat's regional 
leadership, the city of Maastricht and a consulting company was established in May 1997. In a series of meetings they tried to think of possible redesigns for the highway that cuts through Maastricht. In this section I will focus on the work of this Design Workplace, which struggled with all the different forms of embeddedness discussed above.

In this episode of the redesign process, tensions between the requirements for the new highway design and the obduracy of the highway that resulted from its embeddedness played a crucial role. Carla Konsten, former project manager of Rijkswaterstatt's engineering department and former chair of the Design Workplace. and Frans Hendrikx. Rijkswaterstat project manager Highway A2, emphasized the constraining role of rules and legal noms in highway design. The available design options for highways (what is allowed in highway design and what is not) depend on how a particular road is classified. In the Netherlands, ROA guidelines (Richtlijnen Ontwerp Autosnelwegen) atre used to design highways. These guidelines consist of several standardized requirements for designing salfe and comfortable highways.

As pointed out above, the A2 through Maastricht became defined as a "main transport axis" in the Second Structural Plan for Traffic and Transportation." This implied, for example, that designers had to assume a maximum speed of $120 \mathrm{~km} / \mathrm{h}$ as guideline. ${ }^{14}$ However, in November 1992, the Dutch Minister of Transportation, Hanja Maij-Weggen, devalued the urban section of the A2 in Maastricht by no longer classifying it as a highwaly, but as a major secondary road. This decision had consequences for the possible design options. For example, the curve in the existing urban section of the $\mathrm{A} 2$ was actually too narrow for a highway, but this problem was solved in the new situation because the road's new classification calls for a maximum speed of only $90 \mathrm{~km} / \mathrm{h}$. This lower maximum speed required less space for the curves according to the ROA guidelines, which meant that fewer apartment buildings would have to be demolished (see Figure 4.9).

The history of the effort to redesign the highway is marked by a continuous discussion about the preservation or demolition of elements of the town planning structure in which the highway was embedded, in particular the (residential) buildings alongside the highway. The city strongly adhered to the idea of a tunnel, but it also felt that monuments or characteristic buildings near the passage had to be preserved as much as possible. "is Armand Cremers, a liberal democrat ( $\left.D^{\prime} 66\right)$ member of the city board for traffic issues between 1990 and 1998, emphasized the significance of the buildings near the highway in terms of Maastricht's town planning structure. He pointed out that boulevards lined by closed rows of buildings constitute an important pattern in the city's overall town planning structure. Moreover, because the city's eastern part, where the highwaly is situated, already has a more "chaotic" town planning structure than the western part, it would be advisable not to further increase this unbalance. ${ }^{1: t}$ Already in 1990 ), the city board, in a letter to Rijkswaterstaat, stressed that "We are of the opinion that demolition should be avoided on principle. We therefore insist on the development of a design that actually avoids demolition." "To underscore this issue, maps that were made in the context of the redesign effort began to list the Municipal apartment building as a "young" landmark, and in its brochures, the city showed pictures of the road in the early 1960s as the desired image for the future: a quiet boulevard lined with old trees and landmark buildings, while the noisy 
and polluting flow of cars rages on invisibly, in a tunnel, underground. ${ }^{13 x}$

According to Jan Nakken, a landscape architect and chairman of the Design Workplace, a basic choice had to be made on whether the whole area near the urban highway (including the apartment buildings) should be renewed as a whole, or whether the existing town planning structure would be more or less considered as "given", meaning that reconstruction had to take place with as little demolition as possible. The last option was chosen, for the city refused to compromise on the issue of the buildings near the highway. Apart from this argument. costs were also an important consideration: if the option of drastic urban renewal would be chosen, who would have to pay for it? Therefore, the demolition of buildings should be avoided as much as possible, a view that reinforced their obduracy. The Design Workplace gradually defined a speed that required minimal curves and the maximal possibilities for the recovery of the urban fabric as the two major variables in redesigning the highway. At one point, it concluded that only the $90 \mathrm{~km} / \mathrm{h}$ speed would be a feasible option, because it had the least town planning consequences and a minimum of houses needed to be demolished.

The decision to assume a speed of $90 \mathrm{~km} / \mathrm{h}$ did not solve all problems though. Because the demolition of at least some buildings seemed inevitable, the Design Workplace spent quite some time deciding whether it would be better to do so on the west side or the east side of the highway trajectory. ${ }^{142}$ In their deliberations, the role of cultural heritage - monuments or buildings of architectural value - played a crucial role. Although from a town planning perspective the public garden on the west side (Koningsplein) was seen as a great asset, ${ }^{1.3}$ eventually the buildings on the east side turned out to be the most obdurate: in case of demolition on the east side, a national monument, the building of the electrical power company of the Province of Limburg, would have to be moved (cost estimated at 6 million guilders). Moreover, the apartment buildings on the east side were seen as more valuable than the slightly older buildings on the west side. ${ }^{\text {it }}$ Despite the loss of the public garden, demolition on the west side involved fewer buildings and fewer monuments and was therefore regarded a better option.

Another important issue that dominated the discussions of the Workplace participants for months involved the transportation of hazardous materials through the projected tumnel." There was a tension between, on the one hand, spatial and environmental concerns and concerns about the quality of life, and design criteria with regard to the safety of tunnels on the other. If hazardous materials were to be transported through the tumnel, its design had to suit that purpose. Official guidelines stipulate that hazardous materials may be transported through an open tunnel, but that they are not allowed in closed tunnels. The chance of accidents involving trucks was a related concern, in particular the danger of smoke accumulation resulting from buming trucks. In the discussions about the design of a closed tunnel, the fire department played an important role, for it had to approve the tunnel's fire safety. "This issue is still being regulated regarding tunnels. At the same time, noise standards, defined by law, had to be taken into account as well. Obviously, a more or less open tunnel design would be safer, but it would significantly increase noise pollution. ${ }^{1.6}$

At this stage Rijkswaterstaat had not expressed a preference for a particular design, but the available options were limited by a host of laws and design guidelines, 
including ROA, noise standards, municipal and provincial zoning schemes, and safety regulations for tunnels. Similarly, the obduracy of concrete elements of the overall town planning configuration. such as the buildings on the highway's east side, became more clearly articulated at this stage, and this also limited the available redesign options. Finally, it was concluded in the spring of 1998 that the most promising alternatives would be a closed tunnel. a semi-closed tumnel with a narrow opening in the roof, or a ground floor road with overpass junctions of which the local roads would be lowered. ${ }^{1: 3}$

The Design Workplace's main task involved negotiating the obduracy of (elements of) the urban highway. The participants considered the highway as part of a larger whole - e.g. the overall town planning structure, ROA guidelines, and ideas about cultural heritage - rather than as an isolated phenomenon. By thus highlighting the road's embeddedness it became more difficult to come up with radically new alternatives: the participants were aware that changing one element required the adaptation of others, and that a solution that favored certain aspects had negative implications for others. In contrast to the Infralab procedure, citizens were not directly involved in the Design Workplace. It is also important to stress that, like town planner Riek Bakker in the Hoog Catharijne case (Chapter 3), most Workplace participants initially were relative outsiders to the long-term effort aimed at reconstructing Maastricht's highway. However, in the end, the solutions proposed by the Design Workplace were not implemented because of changed political and financial priorities at the national governmental level.

During the Trajectory/EIS study, a new government was installed in September 1998. The new Minister involved, Tineke Netelenbos of the socialist party (PvdA), introduced a new long-term Program for Infrastructure and Transportation (Meerjarenprogramma voor Infrastructuur en Transport) for the period until 2010. For this entire period, she set aside a total amount of 67 billion guilders, a figure that is not enough to carry out all planned infrastructure projects nationwide. The selection of the numerous projects was based on previous agreements with local authorities, as well as on the extent to which the infrastructure measures were expected to contribute to the Dutch economy at large. In the period between 1994 and 1998, the conservative-liberal Minister of Transportation, Annemarie Jorritsma (VVD), had de-emphasized the role of the national government in policies related to local infrastructure projects. This approach had shifted part of the responsibility for traffic problems and congestion from the central government to the local governments. ${ }^{151}$ Moreover, at the national level a change of priorities had meanwhile taken place, favoring investments in public transport and shipping. Similarly, in the Province of Limburg priorities had shifted from the south of Limburg to projects in the north. ${ }^{164}$ All these factors contributed to Netelenbos's decision not to allocate any funds to the highway project in Maastricht. Instead, she decided to postpone all work on the urban section of the highway through Maastricht until after the year $2012 .^{152}$ 


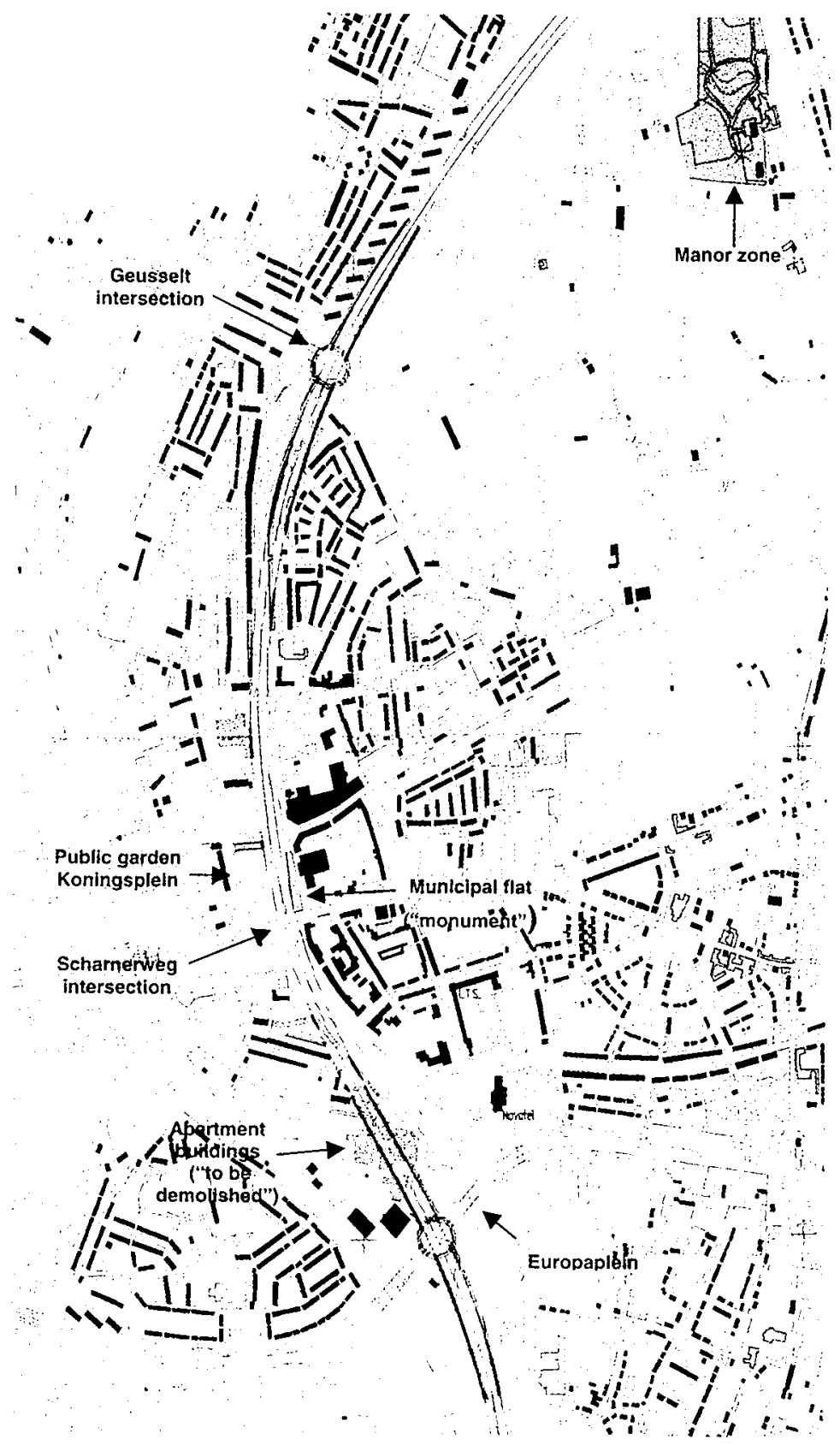

Figure 4.9: Demolition of buildings highway passage, design speed $120 \mathrm{~km} / \mathrm{h}$

Source: J. Nakken Zandvoort Ordening \& Advies Utrecht, adapted by A.Hommels 
Understandably, the city was perplexed. In a letter to the Dutch Prime Minister and the Ministers of Transportation and Housing, the city leadership argued that the minister had failed to take into consideration that the urban highway section not only involved a serious traffic problem, but also a substantial and lingering problem with regard to the quality of urban life. The city council of Maastricht passed a resolution suggesting that it would be unacceptable to postpone the highway's reconstruction once again (after the 1982 decision). It also demanded that the Trajectory/EIS study be finished. Furthermore, it wanted to find out how the implementation of a plan could be accelerated by considering alternative forms of financing (e.g. a public-private partnership). ${ }^{153}$ After deliberations with the minister it was decided that the research already carried out in the context of the Trajectory/EIS study should be completed and that its conclusions would focus on how to facilitate a public-private partnership that might be willing to fund the highway's redesign. ${ }^{154}$

\section{Obduracy and embeddedness}

In this chapter, I focused on the role of embeddedness in the constitution of obduracy in an urban context. I analyzed the attempts between the 1960s and 1998 to "unbuild" the embedded design of the highway that cuts through Maastricht. Since its initial construction, various more or less radical efforts to adapt the highway have been undertaken. The difficulties involved in implementing new designs could not be explained by referring to material factors alone. It has become clear that several other factors also played a major role, such as ideas about cultural heritage, opinions about Maastricht's overall town planning structure, financial considerations, viewpoints about the role of traffic in cities and legal regulations. By stressing the highway's various modes of embeddedness, multiple explanations for the difficulty of changing its design could be advanced and supported.

As my argument revealed, the highway's obduracy - its resistance to change cannot be simply accounted for by material factors, nor by specific dominant ways of thinking of the actors engaged in the redesign effort. In contrast to the Utrecht City Project, technological frames formed a less useful explanation for the existing highway's obduracy. Although it may well be possible to identify different technological frames at work in certain stages of the unbuilding process in Maastricht, these frames were not as dominant and stable as in the discussions about the UCP. In the debates on the tunnel option versus the diversion option that took place between 1978 and 1982, the emergence of two technological frames can nevertheless be discerned. Clearly, the actions and reasoning of Rijkswaterstaat were predominantly derived from the "diversion" frame, whereas the city's views and arguments mainly relied on the "tunnel" frame. However, Rijkswaterstaat worked on tunnel designs at this stage as well. The diversion option disappeared from the agenda of both actors after the decision of the Minister of Transportation in 1982. While the "tunnel" frame continued to be important for the city leadership, alternatives were not excluded from the discussions, as indicated by my discussion of both the Infralab procedure and the Design Workplace.

The main difficulties involved in the effort to redesign the highway emanated 
from its embeddedness in the local traffic system, legal regulations, local user practices and the larger town planning structure of Maastricht. By focusing my discussion on the relations and interconnections between the various sociotechnical elements of the urban section of the highway and the negotiations about the importance of these relations, I demonstrated how, in time, it became increasingly difficult to radically alter the highway's design. The advantage of putting the role of embeddedness in the constitution of obduracy center-stage is that it allows one to better understand the close interrelatedness of the various sociotechnical elements that is so characteristic of cities. Embeddedness, however, should not be merely seen as the outcome of a process, because at some stages of what I identified as the "unbuilding" process it may directly influence the urban redesign process. It is precisely this embeddedness that explains why specific aspects of a city are difficult to change at a given moment (see Figure 4.10 for a chronological overview of elements that contributed to the embeddedness of the city highway in Maastricht).

It is also important to pay attention to the embeddedness of designs that have not yet been realized. The city and residents of Maastricht appear to favor a tunnel, a preference that gained prominence in particular after 1982, even though as an option it has been around for almost as long as the highway exists. Over the years, this tunnel option became linked to the urban ideals and expectations of residents and local politicians alike. My analysis suggests that designs that still have to be realized may nevertheless become solidly embedded in concrete ideals and expectations as well as in local, regional and national policies, and that, as such, they may influence the unbuilding process for long periods of time.

The difficulties involved in dealing with various forms of embeddedness at the same time stood out most clearly in my discussion of the effort of the Design Workplace. Its effort was directed at dealing with the embeddedness of the highway rather than overcoming dominant ways of thinking or traditions. Hence, the design options it generated were much more constrained than the Infralab results. In the Infralab method, the various forms of obduracy discussed in this dissertation were deliberately, albeit temporarily, disregarded. This enabled the articulation of radically new design solutions.

The two major conceptions of obduracy of urban sociotechnology discussed so far, its ties to "embeddedness" and to "dominant ways of thinking," both offer opportunities to the actors involved to disregard obduracy. My first case study suggests that an analysis in terms of technological frames leaves open the possibility that actors can have different degrees of inclusion in technological frames. In my second case study I have shown that actors may temporarily ignore embeddedness altogether. Moreover, I clarified that the very necessity of having to deal with various forms of embeddedness concurrently in urban redesign projects leads to negotiations about the relative importance of the embedded structures, thus pitting them against each other. Or, put differently, given the fact that some embedded structures are more embedded than others, actors always have some space for change, for reconfiguring urban sociotechnology. In the next chapter, which addresses the spatial renewal of the Bijlmermeer, I will further develop this argument by turning to explanations of obduracy that emphasize the role of persistent traditions from which no single actor or group of actors can easily escape. Instead of focusing on specific social groups that 
interact in local contexts, I will emphasize the role of collectively shared rules and values that transcend local contexts, the role of culturally rooted traditions that derive their strength from the fact that many people share them. This case study will allow me to drive home my point about sociotechnology's obduracy, because, in contrast to Hoog Catharijne in Utrecht and the urban highway that cuts through Maastricht, radical changes in the spatial design of the Bijlmermeer have actually been implemented already. 


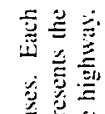

妾总气

늘

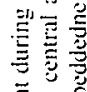

를를

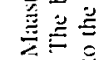

$\Xi \frac{5}{3}$

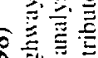

人气

$+\overrightarrow{3}$

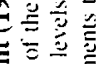
声

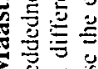
兘

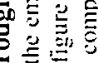
5 记

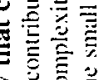
产

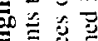

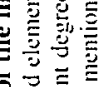

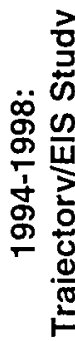

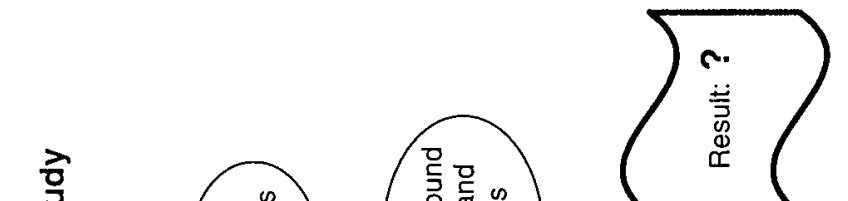

急

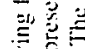
要 三象 Q $\overline{\mathscr{E}}$ 党

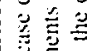
艺.

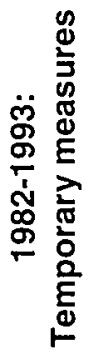

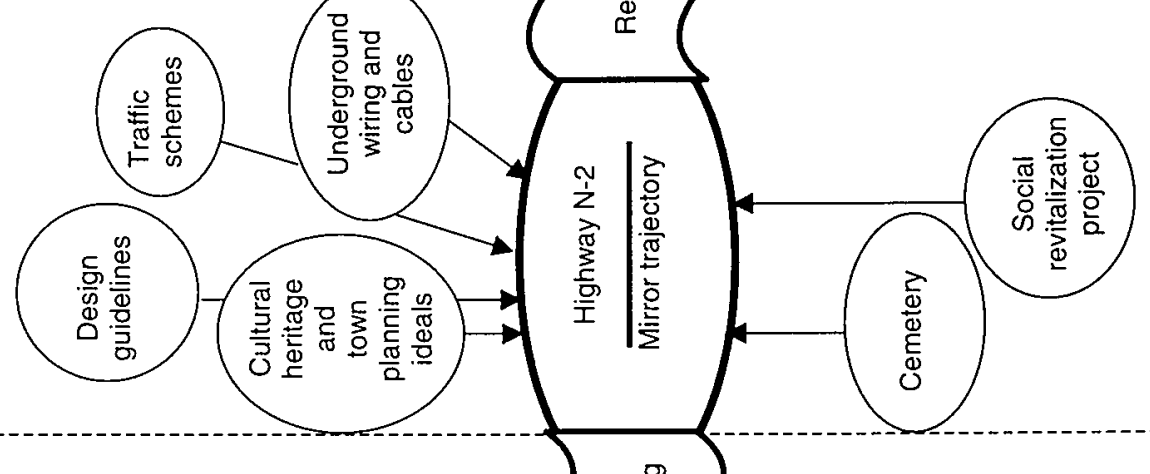

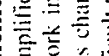

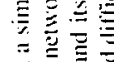
烂焉三

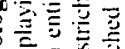

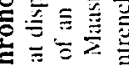

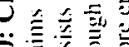
党言至
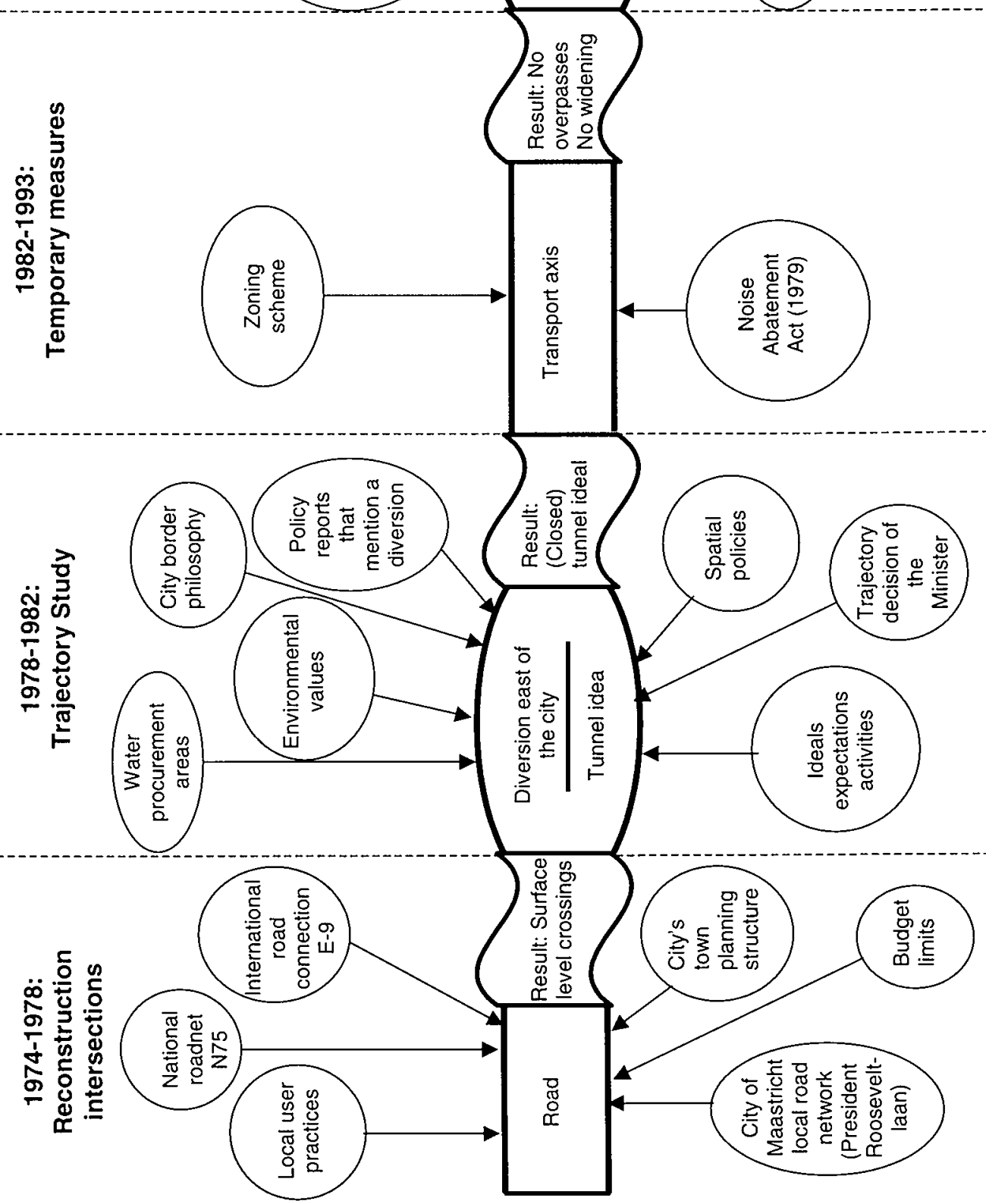


\section{Obduracy and Persistent Traditions: The Spatial Renewal of the Bijlmermeer}

\section{Introduction}

The Bijlmermeer, a suburban district of Amsterdam, was built in the 1960s and 1970s. Its design was based on principles that originated in the modernist town planning tradition and included features like concrete high-rise apartment buildings, large open public spaces, a separation of traffic flows, and an orthogonal layout. The planners of the Bijlmermeer were quite optimistic about their "City of Tomorrow," which catered to middle class families in particular. The many collective facilities were meant to strengthen the sense of community among residents. Moreover, the overall design's uniformity, deliberately not expressing differences in individual life styles, reflected the designers' ideal of social equality.

In the 1970s and 1980s, however, the Bijlmermeer - commonly abbreviated as the "Bijlmer" - became one of the most harshly criticized suburban projects of the Netherlands. It elicited much controversy, and understandably so, for the noble social ideals of the designers and the social dynamic that actually evolved in the Bijlmer could not have been more at odds. It soon became clear that the neighborhood had little appeal, in part because of its then fairly isolated location on the city's edge, and quite rapidly it deteriorated into Amsterdam's most impoverished and crime-ridden suburban district. After years of contention and ardent debates, in which community workers, Bijlmer residents, local politicians, neighborhood council members, architects, town planners and housing officials took part, it was decided in the early 1990 s that in order to solve the problems a rigorous spatial renewal would be necessary, including the demolition of $25 \%$ of the high-rise apartment buildings. In this chapter I will describe the various discussions and negotiations that led to the Bijlmermeer's spatial renewal. While some of the actors involved favored an altogether new town plan for the Bijlmer, thus pushing for a radical break with the modernist concept on which its design was based, I will argue that its original utopian principles continue to play a role to this day.

If Chapter 3 addressed how the degree of inclusion of groups of actors in specific technological frames contributed to the obduracy of (parts of) Hoog Catharijne in Utrecht, while Chapter 4 focused on embeddedness as a major factor in the obduracy of the highway in Maastricht, in this chapter I will explore the persistence of traditions as a central explanation for the obduracy of suburban 
sociotechnical design in Amsterdam. This perspective highlights the role of culturally embedded, long-term, collective (town planning) traditions that contribute to the obduracy of urban structures in a specific context. I will argue that the specific features of the modernist town planning concept and certain characteristics of the utopian tradition that became embedded in this town plan, such as constructability', community spirit and rigorous consistency, kept influencing the discussions, negotiations and choices in the spatial renewal process of the Bijlmermeer until the late 1990s, long after many of the defining circumstances of the original town plan had become obsolete. Although the modernist tradition in town planning was already heavily criticized in the $1960 \mathrm{~s}$, its principles and dogmas persisted in the design practices and ideals of town planners, architects and residents. I will show how these actors kept "mobilizing" the modernist town planning tradition in their arguments to either preserve or demolish specific parts of the Bijlmer.

First, I will discuss the political ideals and the social and normative values that were built into the design of the Bijlmermeer. Next, I will analyze the role of the modernist norms and values in the various attempts of Bijlmer residents, policy makers, town planners, housing corporations, architects and community workers to change or preserve the Bijlmer. In so doing, I focus on the years between the mid1970s and the late 1990s, a period in which an increasing number of aspects of the Bijlmer's original design became subject to debate. Finally, I will not only argue that the effort to preserve the neighborhood's modernist character played a crucial role in the construction of the obduracy of the Bijlmer, but also that the same is true of the deliberate effort to move away from its original concept.

\section{Establishing a tradition}

The Bijlmermeer, designed and built in the 1960s and early 1970s, ${ }^{2}$ was planned as part of Amsterdam's General Extension Plan by the city's Town Planning Department of Public Works (see Figure 5.1). The design of the Bijlmermeer relied on a specific interpretation of the modernist tradition in architecture, its main features being the strict separation of traffic types and the homogeneity of building types. The Bijlmer was conceived as a decidedly functionalist urban district, assuming a stringent separation of living and working, of traffic and recreation. Architect Rem Koolhaas, for instance, argued that "the Bijlmermeer is the product of an architectural dogma most considerately practiced by CIAM in the 1930s - but realized with retrospective effect."

Generally, Le Corbusier (1887-1965) is regarded as the founding father of the principle of functional separation. His ideas were adopted by CIAM (Congrès Internationaux d'Architecture Moderne, 1928-1959), an international group of modernist architects who tried to anticipate the challenges that societal changes and the increasing world population were creating for industrialization, housing and town planning. ${ }^{4}$ Sociologist Magali Sarfatti Larson, who studied the shifts in twentiethcentury architectural discourses, points out that in this area the first and most farreaching change occurred in the 1920s with the emergence of the Modern Movement, 
in which theorists and architects from Germany and the Netherlands participated in particular. After World War Two, an adapted version of European Modernism became known as the International Architectural Style. ${ }^{5}$

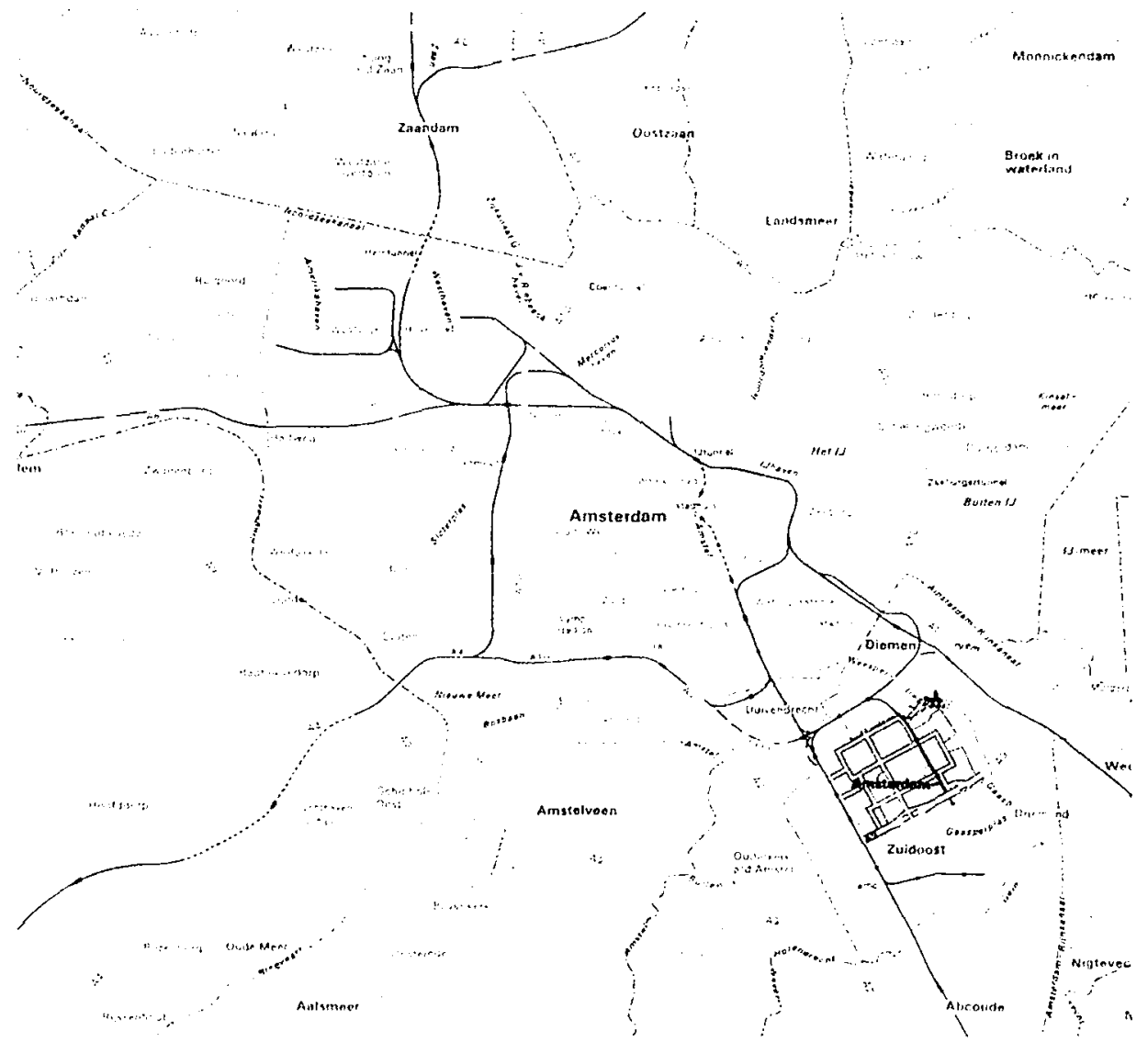

Figure 5.1: Location of the Bijlmermeer in relation to the city center of Amsterdam (1990) Source: Geo-informatic Amsterdam. Kartografische Dienst (1) Geo-informatic Amsterdam, Kartografische Dienst

CIAM was established in 1928 in La Sarraz. The main principle of CIAM was that town planning should be based on functional considerations rather than aesthetic ones. "The Functional City" was the main topic at the fourth CIAM conference held in 1933 in Athens. The conference's chair, Cor van Eesteren, chief architect of the Urban Development Section of Amsterdam's Public Works Department since 1929, was one of the people in charge of the city's General Extension Plan. Based on an analysis of major urban problems, CIAM architects formulated a number of basic analytical guidelines for the design of new cities: housing should not be situated too close to roads for traffic; high-rise buildings had the advantage of allowing more space for recreational purposes; green open spaces should be distributed equally throughout the 
city; residential and commercial areas should be not too far apart and they should be well connected; and the separation of the various flows of traffic can be realized by creating overpass junctions. Le Corbusier reformulated these principles in a document that became known as the Charter of Athens; it is viewed as the doctrine of modernist town planning." Based on these assumptions, Le Corbusier designed a number of town plans, such as "Plan Voisin" (1925) and "La Ville Radieuse" (1930), which became major sources of inspiration for town planners and architects."

"The contribution of Le Corbusier's utopian city to the twentieth century can be seen in the tower-block housing estates which went up on the outskirts of all the major Western cities," Pamela Neville-Sington and David Sington claim in their book on the influence of utopianism on the modern world." However, Dutch historian of architecture Auke Van der Woud argues that in postwar town planning CIAM has been less influential than is usually assumed. Although many urban districts that were built in the postwar era suggest some sort of functional separation, like, for instance, those consisting of high-rise apartment blocks in rows surrounded by green public spaces, it is not always correct to label them as instances of CIAM town planning. Van der Woud conjectures that the views of CIAM were spread via rather "obscure" magazines, which renders it doubtful whether those in charge of planning new neighborhoods were actually familiar with them. Moreover, the rationalization of the construction business after World War Two was a consequence of concrete postwar circumstances, such as the great lack of housing and the rapid population growth, rather than a "logical" effect of CIAM. Van der Woud also suggests that CIAM proponents have put much effort in claiming that their viewpoints were at the basis of these town planning developments. This "optical illusion", he claims,

\footnotetext{
came into being because postwar housing was built in accordance with the same methods as those which had been analyzed and propagated in the twenties by the then modern architects and this created related architectural images, especially in the sixtics, the period of widespread high-rise building."
}

The architecture of the Modern Movement, Le Corbusier's architecture in particular, has often been situated in a longer-term utopian tradition of town planning. Philosopher of technology Hans Achterhuis distinguishes three characteristics of utopia: (1) utopia assumes a strong sense of constructability and controllability; (2) it is aimed at the establishment of an (ideal) community; and (3) it relies on totalitarianism to achieve radical social change." These characteristics can also be applied to the work of Le Corbusier. Neville-Sington and Sington make clear that Le Corbusier saw architecture as a means of control and the city as a machine. The city could contribute to making life orderly, balanced and efficient." Suggesting that Le Corbusier's architecture was aimed at changing social behavior "without the need for outright political revolution," 2 the two authors situate this aim in a longer and influential tradition in town planning of achieving "salvation by bricks alone": "The ideal city was not just the location of the perfect society, it was the means to bring it about." With regard to utopianism in town planning, a slightly different interpretation can be given of Achterhuis's third characteristic of utopia. Totalitarianism can also be 
understood as the sense of totality or rigorous consistency that is usually strived for in the modernist tradition. This becomes particularly clear in the widespread modernist practice of designing blueprints or "masterplans" that imagine altogether new worlds altogether new, "ideal" communities, cities or societies.

A number of political and social values that can be characterized as utopian were also at the basis of the Bijlmermeer design." One of the challenges for the project's designers in the 1960 s was to produce a new housing concept, a new, suburban type of living for a specific group of citizens: middle class families owning a car. ${ }^{15}$ The designers clearly considered social equality a major principle or value, since the plan left little or no room for expressing a sense of individuality or an individualist lifestyle; not surprisingly, the Bijlmer design has often been characterized as egalitarian or even socialist." Another value that the design was meant to promote was a sense of community: the various apartments and car parks could be reached by means of indoor walkways, along which meeting places, shops, leisure rooms and day nurseries were to be situated." At the same time, everyone's privacy had to be protected, an issue that was seen as a sine qua non for the growth of any happy community. The homes and apartments were designed to create "as much privacy as possible for the family inside their house," but outside "the mutual contact between the residents" had to be optimally stimulated by the design as well."

Scaling-up was another aim of the designers and architects of the Bijlmermeer. In their view, increasing urbanization would inevitably result in a more functional spatial division between work, housing, mobility and all sorts of facilities. To create uninterrupted areas of public green space and to guarantee maximum privacy, huge blocks of high-rise apartment buildings were planned. These were constructed by relying on the comparatively inexpensive and fast method of system building. In the Bijlmer, this resulted in a design based on nine-story apartment buildings shaped in the form of honeycomb ensembles (see Figure 5.2). ${ }^{14}$ Ninety percent of all housing in the Bijlmer consisted of these high-rise buildings, while the remaining ten percent were projected as single family homes. Although the Bijlmer planning team hotly debated the exact number of high-rise buildings, the housing shortage and the ensuing pressure to build new homes caused it to opt for the fast and effective solution of highrise apartment buildings."

In the 1960s, there was great concern in the Netherlands for future lack of space as a result of the expected growth of the population. In World War Two, many homes were destroyed and the construction of houses virtually stopped." In the decades immediately following the war housing shortage was seen as public enemy number one and, understandably, it was high on the political agenda. In 1968, Das, Leeflang and Rothuizen proposed several technical measures to intensify the use of land set aside for urban growth." Instead of "space-consuming" low-rise buildings, they expressed a preference for huge urban residential towers. They referred to the Bijlmermeer as an example of a project approximating the ideal of concentrated urbanization, but they felt that the planned high-rises and multi-story car parks were not radical enough, suggesting that space was still wasted. 


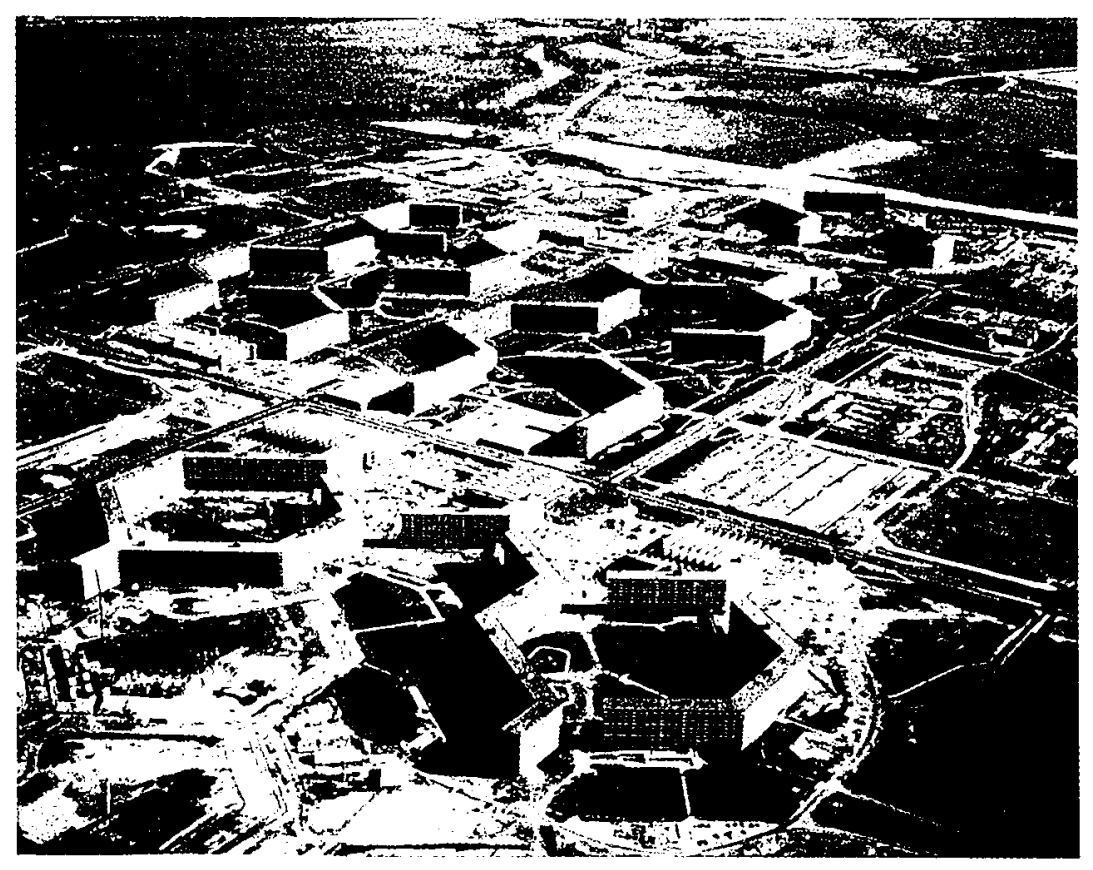

Figure 5.2: Overview from the air: typical Bijlmer apartment buildings, in honey comb shape (September 1971)

Source: Archive Stedelijke woningdienst Amsterdam (O) Stedelijke woningdienst Amsterdam

Apart from the apartment buildings, the traffic system served as an important structuring element in the Bijlmer project. According to the designers, the area's infrastructure of roads had to provide a solid basis for its future design:

\footnotetext{
Traffic and transportation systems and the design of city neighborhoods constitute an indissoluble unity, both from a functional point of view and (partly because of that) from a formal point of view. ... A major divergence from the configuration's basic layout and assumptions is impossible without being detrimental to its functionality."
}

One of the ideals on the minds of the planners involved the creation of a living space, a spacious green zone that was not accessible to cars. ${ }^{2+}$ The residents should feel like they were living in a park. In their effort to achieve this effect, the planners and architects of the Bijlmer tried to avoid some of the "errors" that had been made in the Amsterdam garden cities that were built in the 1950s. ${ }^{25}$ Concretely, this resulted in banning car traffic from the immediate living environment of the residents." Automobiles were exclusively allowed on the semi-elevated roads that gave access to the large multi-story car parks. The size of the car parks was based on the expectation of increasing car ownership, projecting 1.5 cars for each family. Pedestrians were not allowed on the semi-elevated roads. For them, the planners created an autonomous system of ground level walking routes (see Figures 5.3 and 5.4). 


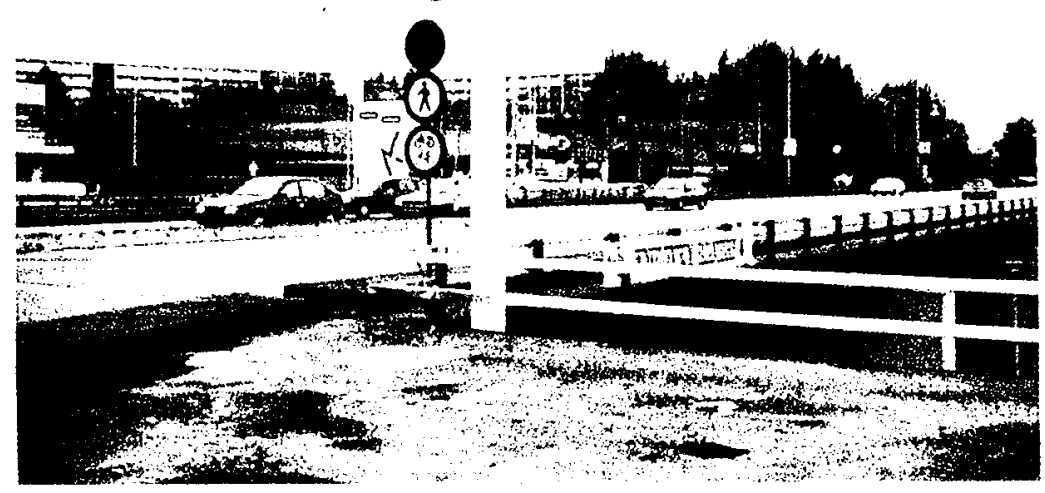

Figure 5.3: Segregation of traffic types: This part of the Bijlmerdreef is not accessible for pedestrians and cyclists (1998) Picture taken by A. Hommels

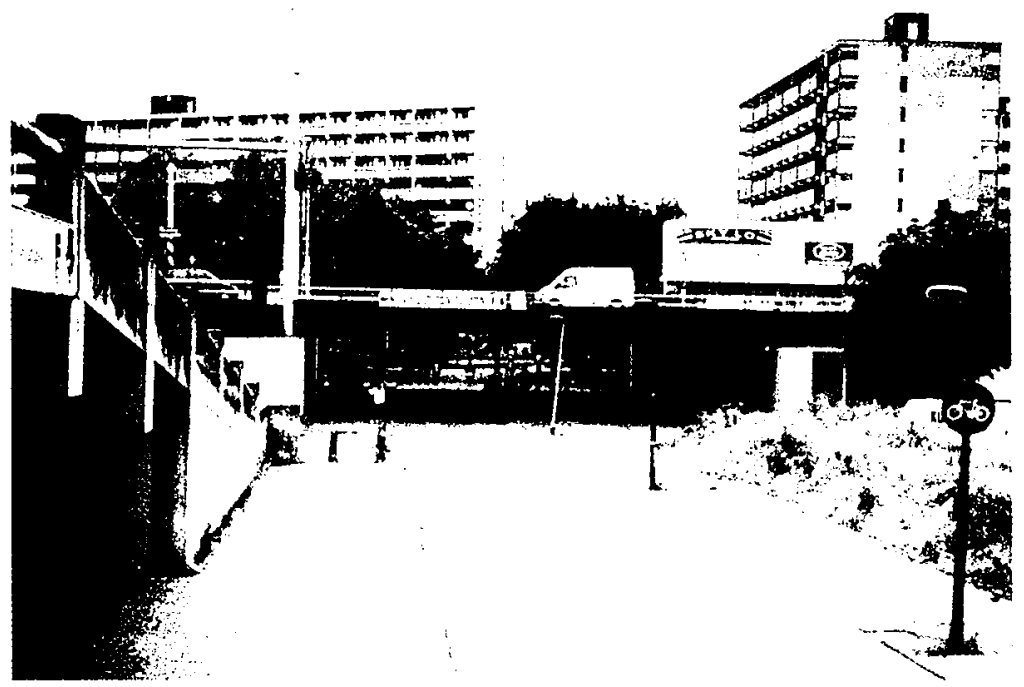

Figure 5.4: Segregation of traffic types: Separate roads for pedestrians and cyclists (1998) Picture tiken by A. Hommels

Although some of the design principles were already abandoned before the project's completion, the Bijlmer is generally perceived as a far-reaching application of modernist town planning, infused with socialist and egalitarian principles. During its construction, severe financial problems occurred, which inevitably led to budget cuts. ${ }^{27}$ Facilities like elevators, telephone boxes, waiting rooms, shops and letterboxes were planned, but never fully realized. Furthermore, the building of the multi- 
functional car parks led to delays in the planning process, which in turn delayed the building of the shopping centers that were situated below the parkings. ${ }^{2 .}$ Moreover, in the early 1970s the network of bicycle paths, traffic roads and public transportation (the subway) failed to function properly."

Thus, a number of modernist town planning principles became embedded in the Bijlmer's overall configuration, including the apartment buildings, road system, indoor walkways, car parks and open public spaces. Utopian town plans like Le Corbusier's have been blamed for their failure to take into consideration "the way real flesh-and-blood people live and act." In fact, architects tend to be frequently criticized for their unrealistic views of society, if they are not characterized as "poor sociologists," as one Dutch journalist does in an article about the Bijlmer." Many times utopian urban ideals are only partially realized in concrete modernist town plans, and this is not without consequences for our urban environments:

Real cities do not remain as static as the ideal cities must to retain its special status... Therefore the schemes of men like... Le Corbusier can never be fully realized; yet their partial implementation has had a tremendous impact on our landscape. We live surrounded by the fragments of their utopian dreams."

Indeed, once the neighborhood was almost finished in the 1970s, the Bijlmer failed to live up to the expectations of the planners and the inhabitants. Quite soon, the Bijlmer became heavily criticized on different levels. Residents criticized the partial execution of the plans, the finances and management and the initial absence of residential facilities. Moreover, despite the initially enthusiastic reactions to the Bijlmer concept, ${ }^{33}$ later on its town-planning concept was heavily criticized as being "superseded" by social developments. ${ }^{34}$ Already in the 1960s, the town planning profession firmly condemned the uniformity and monotony of town districts." From being seen as an icon of modernist architecture the Bijlmer quickly transformed into a symbol of the failure of modernist architecture. Functionalist views were often seen as the principle cause of what was called the "dehumanization of modernist town planning.", The authors of a study of the Bijlmer suggested that its town-planning concept "became more and more an oppressive predicament" that proved hard to reverse. "The Bijlmer's modernist, functionalist ideals were seen as outdated and the neighborhood became viewed as an "anachronism." ${ }^{3 \times}$ In another report the Bijlmer was characterized as poorly planned, especially because of its overall inflexibility; the authors felt that to most residents the project was basically "dysfunctional."."

Some critics perceived a fundamental discrepancy between the practical aspects of the Bijlmer's design and the socio-cultural developments in Dutch society during the closing decades of the twentieth century, and they believe that this is the main reason for its "failure." As a residential concept, the Bijlmer did not cater to a particular social need. Town planner Dirk Frieling suggested that

One reason for the technical failure of the Bijlmer is that the technical concept has never had an administrative form to match, and it seems as though. even now, no one is really interested in finding one." 
And Bernadette de Wit, journalist and Bijlmer resident, argued, "The institutions had no answer to the specific demands of a neighborhood like the Bijlmer; their traditional routines and procedures did not fit our whimsical reality."

Besides this critique of its design and architecture, the public image of the Bijlmer became very negative for other reasons. Plagued by unemployment and high crime rates, the Bijlmermeer had become one of the most criticized urban districts of the Netherlands by the 1980s. It became associated with crime, unsafety, drug use, high unemployment rates, disorder, vandalism, illegal immigrants and unattractive architecture. In time, the public image of the Bijlmermeer became so negative that Bijlmer residents felt the responsibility to defend their neighborhood by publishing a report:

The Bijlmer is in many respects a failure of a number of administrators. town planners. planners and other experts. But the Bijlmer is certainly not the hopeless case it is often portrayed to be in both the professional and tabloid press since the first residents moved in. With this report, the inhabitants of the Bijlmer wish to fight this image of the neighborhood as a cesspit of misery, crime, vandalism and vice."

De Wit argued that after the mid-1980s, cynicism about the Bijlmer further increased. Politicians no longer believed in the Bijlmer: "They abided with the half-finished product they ended up with and no longer tried to complete it with respect for the original design." ${ }^{* *}$

Below, I will specifically focus on the role of the modernist CIAM tradition in the various attempts of the actors involved - Bijlmer residents, policy-makers, town planners, architects and community workers - to either change or preserve the Bijlmer's original concept. These actors "mobilized" specific aspects of this tradition to argue for either adaptation or preservation. Many solutions have been put forward since the mid-1970s, including the more recent proposals to demolish parts of the Bijlmer and to formulate an altogether new town planning structure. In describing these endeavors, I make a rough distinction between three phases. The first phase comprises the years between 1974 and 1986, during which only minor adaptations were proposed while the existing town planning structure of the Bijlmer was largely preserved. In the second phase, between 1986 and 1992, the basic outlook of the Bijlmer and its town planning principles were no longer taken for granted anymore, which prompted the first concrete proposals for demolition and fundamental redesign. In the third phase, from 1992 up to the present, the spatial renewal actually got underway. 


\section{Persistence of tradition: Maintaining and improving the established town planning structure (1974-1986)}

From the outset it had become clear that the ways in which the Bijlmer residents used and experienced their new environment did not always correspond well with the intentions of the designers of the Bijlmer. As Lucas van Herwaarden, a Bijlmer resident and local landscape architect, observed: "the first cracks in the ideal image invented by the specialists were induced by usage." started to use the huge, empty, freely accessible multi-story car parks for commercial activities, such as restaurants and shops, while homeless people and drug addicts soon discovered them as good places to spend the night. Furthermore, instead of appreciating the large areas of collective public space, Bijlmer residents began to divide some of them into small private lots for gardening (see Figure 5.5). The originally planned public footpaths were diverted by frequent use (the so-called "elephant paths"), and, more troublesome perhaps, balconies and other public spaces became used as sites for dumping garbage. These interpretations and practices indicated a break with some of the ideas originally embedded in the Bijlmer concept. In this way, the actual usage of the built environment already contributed to its "unbuilding." However, other, more formal attempts at adapting the Bijlmer to the needs of its residents appeared to be more difficult to execute.

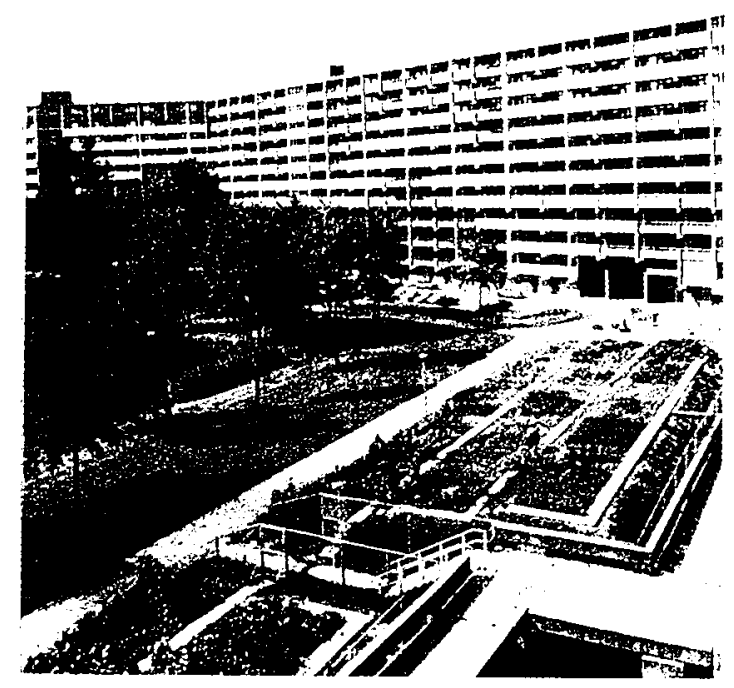

Figure 5.5: Small private gardens and parking at street level (September 1986)

Source: Stedelijke woningdienst Amsterdam @ Stedelijke woningdienst Amsterdam 
In 1974, the municipal Housing Department of Amsterdam established the Bijlmermeer Management Group, to be directed by architect and Bijlmer resident Pi de Bruijn. This group tried to improve the Bijlmer's living environment by proposing a range of practical measures. De Bruijn was very frustrated, for example, by what may seem an inconspicuous detail: the great number of doorsteps in the Bijlmer apartment buildings. He lived on the eighth floor and when he needed to go and get something from his storage space in the basement he had to cross no fewer than twelve doorsteps, each of which he saw as a disturbing obstacle. To gain support for this concern, he established an action group called "Bijlmer Without Doorsteps" (Bijlmer Drempelvrij). ${ }^{45}$ Another initiative of the Bijlmermeer Management Group involved its proposal to set aside parts of the large areas of green public space for smaller private gardens. In De Bruijn's view, the Bijlmer's design failed to cater to some of the practical everyday needs of residents:

\begin{abstract}
[In the Bijlmer] there are lots of places that are not accessible by cars. ... There is an ill-defined and often very messy area between the public roads and the front doors of the apartment buildings. Imagine that you are going to die in one of those apartments: how can you get out of it'? ... Or suppose that you want to get married - a social event that most view as a special occasion. I noticed that they [the planners] had not thought about that..."
\end{abstract}

De Bruijn explained that some minor adaptations were made to improve these situations, but that other changes appeared to be very difficult to realize. The planners and architects who designed the Bijlmer were against all proposals that did not comply with their view of the Bijlmer as a modernist town district based on a socialistegalitarian concept. Moreover, the Town Planning Department legally consolidated the existing layout in a zoning plan that was ratified in 1974. ${ }^{47}$ As a consequence, De Bruijn contended, it was impossible to put in extra windows in a number of apartments or to create new apartments at the ground floor level, because for some reason this did not comply with the overall design's egalitarian principle." He left the group in 1977 because he felt the problems had grown too complex and wide-ranging.

In 1980, a group of Bijlmer residents joined forces in a working group, called the Bijlmermeer Community Workers Foundation, and their aim was to write a report based on their experiences. They sought to make a positive contribution to the solving of problems in their neighborhood. The problems they identified ranged from larger social issues, such as the "imbalanced make-up of the Bijlmer population," and issues related to the overall design, such as noisy apartments, bad signposting and long walking distances, to quite concrete problems associated with the availability of facilities and their maintenance. In the working group's report an appropriate solution was formulated to each of the problems."

Before the mid-1980s, policy makers defined the central problem of the Bijlmer mainly as a housing problem. In 1982, the city and the Amsterdam Federation of Housing Corporations founded the Project Group on High-Rise Buildings in the Bijlmermeer." In their report "A Plan for the Bijlmer," they limited their concern to housing problems that could be solved in an instrumental manner." According to the 
authors, the central problem was the increasing number of vacancies in the high-rise apartment buildings of the Bijlmermeer." Already in 1970, the Municipal Housing Department of Amsterdam noted in a report that the Bijlmer's average percentage of rented apartments and homes was not as high as expected. A 1983 report of the Amsterdam Council for Urban Development concluded that this problem was caused by a number of unforeseeable developments: (1) the Bijlmer's population turned out to be quite different from what had been anticipated: while members of the targeted middle class proved to be only marginally interested in living in the Bijlmer, various new groups of migrants and workers from other countries did end up there; (2) many planned social and cultural facilities and shopping centers had never been completed; (3) in the economically constrained years many of the residents were seeking cheaper accommodation because of the high rents and service costs in the Bijlmer." The authors concluded, in short, that the Bijlmer was never truly completed and that therefore all planned facilities should still be put in place.

In the 1970s, the Bijlmer evolved into a haven for members of various marginal social groups, such as refugees, migrants, and illegal immigrants. Moreover, the drug scene that was previously based in parts of downtown Amsterdam had moved to the Bijlmer. As a result, drug use and crime increased in the Bijlmer and its public image became increasingly negative." After Surinam, a former Dutch colony, gained independence in 1975, many Surinamese people, who were given the opportunity to remain Dutch citizens, moved to the Netherlands and ended up in the Bijlmermeer." Partly as a result of Amsterdam's malfunctioning system of housing distribution, some of the apartments became overcrowded. One of the apartment buildings. named Gliphoeve, was particularly notorious in those days. The Amsterdam Federation of Housing Corporations concluded that this building had to be either demolished or radically changed. At that time, however, in the eyes of both the city board and the national government demolition was out of the question: the buildings were only eight years old and there had always been a housing shortage in Amsterdam." It was therefore decided that the building ought to be completely remodeled, involving, among other things, the closing-off of the indoor walkway and the realization of a new road where residents could park their cars adjacent to the building."

The Project Group on High-Rise Buildings in the Bijlmermeer concluded that these buildings did not attract many people. It explicitly disputed the opinion that the Bijlmer town planning concept might be substandard and proposed a new policy for the Bijlmer to achieve differentiation in the high-rise areas. On purpose, though, this policy excluded the option of a radical change of the original town planning principles. It emphasized that the town planning principles of the Bijlmer should not be relinquished, not even regarding details." The Project Group also proposed a number of practical measures such as lowering rents, closing off interior walkways, adding elevators, providing ground level parking areas, adding ground floor apartments, improving promotional activities, fighting drugs and so forth. Furthermore, it proposed to replace the various existing housing corporations by a single new one, which would be in charge of rentals and management for the entire Bijlmermeer. In 1984 a new housing corporation, called Nieuw Amsterdam, was indeed established. 
The efforts to either change or preserve the Bijlmer in the period between the mid-seventics and the mid-eighties can be summed up as follows. First of all, the local practices of Bijlmer residents who started to make different use of the Bijlmer contributed to a softening of the Bijlmer concept. In official attempts to adapt the Bijlmer, the idea that the high-rise buildings should be preserved in their existing form, as well as the notion that management of the apartment buildings and the living environment should be intensified, was maintained as a policy guideline." Although the Amsterdam Federation for Housing Corporations proposed demolition in the case of the Gliphoeve building, this never was truly a serious option. In this period, the proposals assume either the "finished" character of the neighborhood or the idea that the Bijlmer is still "unfinished" and ought to be completed along the lines of the original concept. Although some of the adjustments were only minor, such as closing off interior walkways or removing thresholds, other measures, such as experiments with parking at street level and the idea of creating more differentiated apartment buildings, meant a more significant deviation from the original concept. In general, however, measures were not aimed at a radical deviation from the original town planning principles. According to De Bruijn, chair of the Bijlmermeer Management Group, the Town Planning Department blocked all of the more radical attempts at change proposed by Bijlmer residents and the Bijlmermeer Management Group (such as creating extra windows in a number of apartments or to create some apartments on the ground floor) that did not comply with the Department's view of the Bijlmer. ${ }^{\text {(t) }}$

This first stage of rethinking the Bijlmer shows a striving for conceptual consistency of town planners, architects, and politicians involved in the planning of the Bijlmer: changes were allowed as long as they were in line with their view of the Bijlmer's overall concept. In their arguments to preserve the Bijlmer, policy makers and architects explicitly mobilized the town planning tradition of the Bijlmer. During this phase, deviation from this tradition was generally not considered the right way to solve the Bijlmer problems. According to the Bruijn, one aspect of the Bijlmer tradition was particularly emphasized in this phase: its socialist-egalitarian roots. Thus, the relative obduracy of the Bijlmer in this phase can be at least partly explained by the importance attached to the town planning tradition on which the Bijlmer design was based. However, according to René Grotendorst, employee of the Amsterdam Federation of Housing Corporations between 1980 and 1984, other reasons for not proposing radical modifications also played a role. For one thing, the buildings were still fairly new, so demolition was not considered to be a reasonable option. There had been a housing shortage in Amsterdam for years and this fact also sharply conflicted with the idea of demolishing buildings. Moreover, most agreed on the quality of the Bijlmer apartment buildings and that they were better than those in most other districts of Amsterdam. It made perfect sense, therefore, to spare the Bijlmer apartment buildings." 


\section{Contested tradition - Disputed neighborhood (1986-1992)}

The measures taken in the early to mid-1980)s had concentrated on streamlining the management of the Bijlmer (by establishing one housing corporation), on upgrading the ground floor level of the apartment buildings, on improving the safety and quality of the apartments, while the rents were lowered as well. These changes were meant to substantially reduce the fairly high number of unoccupied apartments in the Bijlmer. By 1986 it had become clear that these measures failed to work, for as much as a quarter of the total number of apartments was not rented out. Moreover, crime and drug use increased further.

These negative developments signaled that a more radical approach had to be considered. In 1986, the housing corporation, the city government and the national government established the Working Group "Future of the Bijlmermeer" ("Toekomst Bijlmermeer"). In a report, this Working Group presented five scenarios, four of which proposed replacing some of the large apartment buildings with new housing. According to Ter Horst et al., the report's major concern was "that the improvement of the Bijlmer could only be achieved by changing the housing supply." Although none of the four scenarios that involved demolition of buildings acquired the support of the parties - the city, the government and the housing corporation preferred the fifth scenario ${ }^{\text {(i: }}$ - demolition nevertheless became a hotly debated issue from that point on.

In 1987, Amsterdam's Housing Department argued that demolition was not feasible." Its view was based on the following reasoning: demolition found no widespread support among the population, it involved too much a "technical" approach, it would seriously restrict alternative options for improvement, it meant capital destruction and, finally, it ignored results that had already been achieved as well as present town planning options. The Housing Department concluded that the present role of the Bijlmer on the housing market should be accepted. It criticized the past approach in which the Bijlmer problems were defined as limited to housing problems. and emphasized that there was a social dimension to the problems as well. Therefore, it recommended more monitoring and intensive management, while demolition should only be reconsidered if no other solution could be found at all.".5

This proposal was sent to the christian democrat Deputy Minister of Housing, Enneuis Heerma, who rejected it in September 1988. Unwilling to accept the deteriorating situation of the Bijlmer and favoring a more structural approach, he proposed to establish a new commission, again called Working Group Future Bijlmermeer." In the meantime, the financial position of Nieuw Amsterdam, the housing corporation in charge of the Bijlmer, had seriously weakened because of the high management costs. Moreover, the occupancy rate of the apartment buildings had worsened rather than improved, thus further undermining the financial position of Nieuw Amsterdam. Understandably, then, the new Working Group's primary task was to explore how this trend could be reversed.

Its report "The Bijlmer Remains, Open to Change" ("De Bijlmer blijft, veranderen") was published in 1990. In this report the option of demolition cropped up again in quite a dramatic way in a reference to a report by consulting agency Kolpron, in which potential private investors were interviewed. In order to transform the 
Bijlmer into an attractive residential area in the future, these investors argued that radical changes of the existing town planning structure would be inevitable. Especially the "homogeneous population structure" had to be modified. The investors concluded that a maximum potential could only be guaranteed by demolishing the whole neighborhood."

The Working Group, however, did not share this view. It sketched two scenarios for the future of the Bijlmermeer. One scenario was based on the present town planning structure in which a number of instruments were recommended to improve the housing corporation's financial situation." Another scenario delineated a radical change of the present town planning structure. Specifically, it proposed the demolition of $25 \%$ of the high-rise apartment buildings, to be replaced with new lowrise housing; the upgrading of a number of the buildings to a more expensive market segment; a basic remodeling of the remaining apartment buildings; and making improvements in the infrastructure. The Working Group, in fact, favored a combination of the two scenarios, but it saw the original town planning structure as the root of all of the problems. Its report therefore underlined the necessity of demolition by suggesting that scenarios that would hold onto the old town planning structure might succeed in temporarily alleviating the financial problems of the housing corporation, but they would fail to address the "structural problems of the Bijlmermeer.",

Gradually, more voices were raised against preserving the original layout of the Bijlmer, its high-rise apartment buildings in particular. According to architects from the Office for Metropolitan Architecture (a private business), demolition could become a serious option because the public image of the Bijlmermeer had developed into a very negative one. ${ }^{71}$ In part because of its high crime rate, it was perceived as one of the most troubled neighborhoods in the country, and this nationwide attention forced local policy makers, politicians and the managing agency to question the (once) obdurate town planning structures of the Bijlmer. Moreover, the city leadership of Amsterdam did no longer want to be responsible for the financial debts of the managing housing corporation." At that point, it could no longer be denied that radical intervention was called for.

Although the authorities acknowledged the Bijlmer's social problems, these were not the principle reason for the fundamental changes that would be proposed. According to Tineke van den Klinkenberg, a member of the Renewal Bijlmermeer Steering Committee (see below), the decision to build the Amsterdam Arena next to the Bijlmer also played a crucial role in the decision to renew the Bijlmer. It hardly seemed reasonable to build a hypermodern stadium close to a deteriorated town district and ignore its problems." Gradually, a consensus emerged on the need for a fundamental adaptation of its town planning structure. Only if its original concept would be given up at least in part, the Bijlmer could be given a second life. The "demolition of apartments" was seen as "one of the instruments" that needed to be deployed to effect a break with the past."

In November 1990, the city finally agreed with the plans put forward by the Working Group. The managing housing corporation also favored demolition of apartment buildings since it felt that its own survival, as well as that of the Bijlmer as 
a whole, depended on such radical intervention. Although in 1986 the corporation had voted against demolition, now it was prepared to accept the plan because of its poor financial situation."

In 1991, the three partners (city of Amsterdam, the neighborhood board of South-East" and housing corporation Nieuw Amsterdam) established the Steering Committee Renewal Bijlmermeer." Town planner Dirk Frieling was put in charge of the committee, which consisted of representatives from Nieuw Amsterdam, the neighborhood board, the city, as well as two external advisors. One of their tasks was to detine the new planning guidelines for the Bijlmermeer on the basis of the report of the Working Group.

The basic problem that triggered the need for a renewal of the Bijlmermeer is summarized in a letter from the Stecring Committee:

The issue that prompts this operation is the uncontrollability of the Bijlner. as expressed in its disarray, vandalism and unsafety. This causes a high turnover of residents and a high rate of vacant apartments, resulting in huge exploitation losses. This problem is the immediate result of the district s town planning structure, marked. on the one hand. by homogeneous housing in the form of rental apartment buildings for families of average means, and. on the other hand, by expansive public and semipublic spaces that require an excessively large maintenance crew.

Clearly, the Steering Committee abandoned the limited definition of the Bijlmer problems as a housing issue, and defined its particular problems in a much broader light by also taking into account social problems, such as the large number of refugees and migrants in the Bijlmer and the high unemployment among its residents." The plans for the neighborhood's renewal meant a distinct break with previously applied standards. Conceptual principles, like the segregation of traffic types and the uniform daily living environment, were not taken for granted anymore. In many respects, the new plans even suggested a radical departure from the tradition of the Bijlmer's original town planning structure (see Table 5.1).

Table 5.1: Comparison of leading themes in the original Bijlmer concept and the plans of the $1990 \mathrm{~s}$

\begin{tabular}{|l|l|}
\hline Original plans of the Bijlmer & Plans of the 1990s \\
\hline Much public space, large green areas & $\begin{array}{l}\text { Concentration of buildings, less open space and } \\
\text { more controllable open space }\end{array}$ \\
\hline Car-free public space & Car-centered public space \\
\hline Egalitarianism & Diversification, differentiation \\
\hline $85 \%$ \%igh-rise apartment buildings & Mixture of low-rise, mid-rise and high-rise \\
\hline Segregation of traffic types & Mixing traffic lypes \\
\hline $\begin{array}{l}\text { Separation of living. working, recreation and } \\
\text { traffic }\end{array}$ & Mixing of functions \\
\hline
\end{tabular}

The Steering Committee made a distinction between three types of renewal: spatial, social and managerial renewal. Moreover, the Bijlmermeer was divided into two so-called "focus areas": Ganzenhoef and Amsterdamse Poort." The neighborhood 
authorities decided that the Bijlmer would be renewed step by step, one area after another. Ganzenhoef was chosen as the first focus area because this section's problems were worst. Moreover, some elements of the original Bijlmer structure were already redesigned in this area. Therefore, it would be easier to bring about more differentiation and the neighborhood board expected less resistance from the residents. Demolition of $25 \%$ of the apartment buildings continued to be the Steering Committee's main goal. For Ganzenhoef this meant the demolition of two buildings. In addition, the Committee proposed to lower the Bijlmerdreef, the main road in the Bijlmermeer.

The neighborhood board was divided on the renewal plans. In July 1992 the newly developed town planning guidelines for Ganzenhoef were discussed in the neighborhood council. It appeared to be very difficult to win the council's support for this plan. The representatives of Groen Links, a leftist political party in both the city council and the neighborhood council, argued against the proposals for the demolition of two high-rise apartment buildings. They were afraid that the demolition of two of the buildings would cause a concentration and aggravation of the problems in the remaining apartment buildings. They commented that the demolition plans were premature because they had not passed the city council yet, and they also doubted the view that there would be no demand for the apartments. To substantiate their point. they showed statistics that indicated a recent lowering of both the vacancy rate and the turnover rate. ${ }^{\text {s. }}$

The neighborhood board very much insisted on the social renewal dimension of the plan, but it had great difficulties with the drastic nature of the spatial renewal plan. Former neighborhood board member and chairman of the neighborhood council Ronald Janssen, a member of the social-democratic party PvdA, argued that spatial renewal was seen as a precondition for social renewal. The board was not against demolition, but wanted to have more scenarios than the one presented in the Ganzenhoef plan. However, according to Janssen, the neighborhood council was pressured by the city to accept the proposed plan. ${ }^{x 2}$ Finally, it indeed was accepted, but, in response, two city board members (from Groen Links) stepped down. Janssen explained the council's decision with reference to the momentum that was building at that time, a situation from which it could not escape anymore. The start of the process was more important than the specific results in the Ganzenhoef area, so the council felt it needed to accept the plan. ${ }^{x i}$ Its decision seemed to have important ramifications, though, because it set the stage for further plans and the subsidies that were requested. For instance, the Central Housing Fund supported the renewal with a large subsidy, but this generosity, in turn, made it difficult to divert from the accepted plan.

It might now seem as if in the early 1990s the Bijlmer had become entirely malleable, subject to whatever urban redesign schemes actors could think of; after all, demolition had become a real option and the basic assumptions of the newly proposed plans seemed to contradict some of the original ideas behind the Bijlmer (cf. Table 5.1). This raises the question if there were also some elements of the Bijlmer that resisted change and maintained their obduracy, despite all the radical proposals? Below I will argue that the agreement to move away from the Bijlmer's original town planning concept did not automatically result in its all-out flexibility. The obduracy of 
many of its elements had to be overcome by negotiation and discussion. In particular two crucial elements of the Bijlmer's original design were heavily debated: the infrastructure of semi-elevated roads and the apartment buildings. I will show how some of the actors mobilized the CIAM tradition in their effort to convince their opponents of need to preserve the obduracy of these urban structures.

\section{Preserving the obduracy of the semi-elevated roads}

The proposed interventions, particularly the lowering of the roads and the demolition of some of the apartment buildings, were controversial. The critique was often couched in terms of the new plans' deviation from the town planning tradition in which the Bijlmer was originally conceived. Residents tried to argue the obduracy of the Bijlmer structures by invoking aspects of the CIAM tradition, in this case the separation of traffic types. For example, a group of Bijlmer residents organized as the "Working Group Housing and Living Environment" (Werkgroep Wonen en Woonomgeving) of the Community Workers Organization Bijlmermeer, saw the semi-elevated roads in the Bijlmer, one of which is the Bijlmerdreef, as a crucial element in the original Bijlmer design and therefore they opposed the plans to lower the Bijlmerdreef. According to many, the road infrastructure of the Bijlmer was even more fundamental to its design than, for instance, the high-rise apartment buildings. As architect Pi de Bruijn argued: "If you change that [the road system $\mathrm{AH}$ ] and preserve the honeycombs, then it doesn't matter what you do, you've still wrecked the Bijlmer.",

Town planner Frieling, however, considered the lowering of the Bijlmerdreef to be one of the most crucial redesign interventions. In his view it was more important to do something about the sinister spaces beneath the Bijlmerdreef or the badly functioning service areas than to revitalize the high-rises. Upgrading the service areas to nice, safe, public domains would strengthen the identity of the neighborhood. Strategically, Frieling wanted to take the attention away from the discussion about the demolition of the apartment buildings and shift it to the lowering of the roads. This strategy was not successful, though, for a number of Bijlmer residents saw this effort as undermining another important element of the Bijlmer concept. ${ }^{85}$ An alternative solution for the ground floor's safety problem was to "compress" the area by building low-rise houses in the green areas near the apartment buildings. Moreover, it was proposed to mix the various flows of traffic: cyclists as well as pedestrians were allowed on the elevated roads that were initially reserved for motorists.

The Working Group Housing and Living Environment disagreed with the proposal to lower the Bijlmerdreef as well as with the idea of demolishing apartment buildings. Following the principles outlined in a first report on the redesign of the Bijlmerdreef, they pleaded against abolishing the separation of slow and motorized traffic because it did not comply with the "basic design" of the Bijlmer:

We want to hold onto both the Bijlmerdreef at its present semi-elevated level and the central area at its present ground floor level because this characteristic set-up determines the way the Bijlmer looks. Lowering the Bijlmerdreef would strike at the roots of the basic design. "st 
Eventually, the Working Group proposed its own, considerably less expensive plan for the road infrastructure of the Ganzenhoef area in which only a small part of the Bijlmerdreef would be lowered. It pointed out that full reconstruction would cost a lot of money that might well be spent for other purposes. The Working Group was also concerned about decreased traffic safety after lowering the Bijlmerdreef:

Demolition of the whole Bijlmerdreef does not provide a solution in terms of livability and safety. On the contrary. the construction of a level road is detrimental to what has been considered as one of the strongest advantages of this neighborhood for years: traffic silfety."

The plan failed to be accepted on the premise that the neighborhood council had already approved a structural plan in which the lowering of the Bijlmerdreef was proposed. ${ }^{\text {ss }}$ However, the Working Group's views on this issue caused the lowering of other elevated roads in the Bijlmermeer to remain a controversial matter. Traffic engineers, for instance, emphasized the advantage of the elevated roads in terms of traffic safety." but from the angle of social safety the three partners in charge of the renewal (the housing corporation, the neighborhood board and the city board of Amsterdam) favored lowered roads." Those who made an effort to preserve the elevated roads did not succeed by mobilizing the town planning tradition of the Bijlmer (see Figure 5.6). Some elevated roads were nevertheless preserved, but financial arguments and the roads' embeddedness in the overall traffic structure and town planning set-up (e.g. the accessibility of buildings and parkings from the elevated roads) were considered more important than the argument that the elevated roads were a fundamental part of the Bijlmer's basic form." 


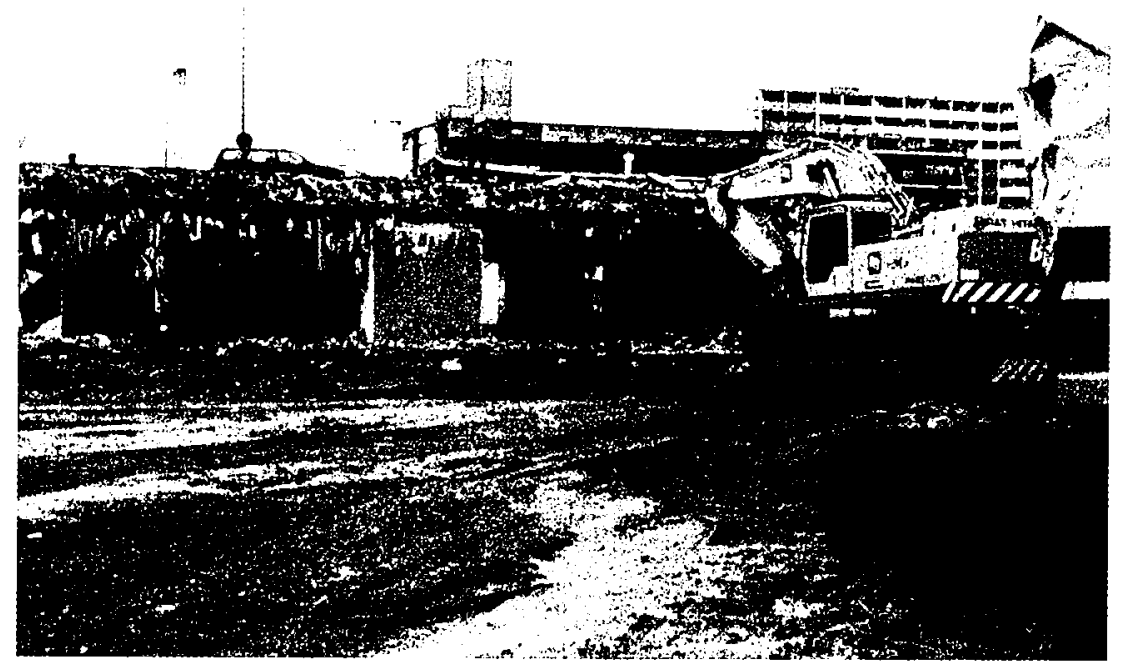

Figure 5.6: Lowering part of the Bijlmerdreef (October 1996)

Source: Archive stidsdecl Zuidoost (1) Publi Art. Schoorl

\section{Demolishing apartment buildings: The role of constructability and community}

In the discussions about the demolition of a number of apartment buildings in the Bijlmermeer, two assumptions of the utopian tradition played a crucial role: the notion that a better society can be made and that a cohesive community can be established by means of town planning interventions. According to the Steering Committee, the renewal's main goal of making housing corporation Nieuw Amsterdam more financially healthy was to be achieved by creating more stability and social cohesion and by strengthening the identity of the Bijlmermeer, including its public image."2 This would result in an increase of the occupancy rate as well as of the duration of rental periods, which in turn would lower the deficits of Nieuw Amsterdam." This goal was to be reached by a combination of social and technical measures - demolition being one option."

It was argued that, due to the lack of a differentiation between types of apartments, those Bijlmer residents whose financial situation improved could not make a "housing career" in the Bijlmer, so they moved to low-rise single family houses elsewhere in the region around Amsterdam or in Almere or Lelystad. According to the Steering Committee, the cultural identity of the Bijlmer could be stabilized and strengthened if residents were to stay on in the neighborhood and not move elsewhere. Therefore, the solution the Committee proposed was to build a larger variety of homes, notably more low-rise single family houses with gardens. It reasoned that by ensuring the availability of this type of housing more solidly middleclass residents would prefer to stay in the Bijlmer while it might also attract such residents from elsewhere. This, in turn, would enhance the district's stability and social cohesion." In financial terms, this strategy would have two distinct advantages: 
the occupancy rate would go up and hence the rental income collected, and, more importantly perhaps in the long run, an enhanced community spirit would substantially lower the management costs associated with apathy and vandalism.

Although the Working Group Housing and Living Environment emphatically shared the value of a strong community spirit, they followed a different line of reasoning: Spatial renewal would cause a disintegration of the Bijlmer's multi-ethnic society rather than strengthening it. The demolition of two high-rise apartment buildings in Ganzenhoef, named Geinwijk and Gerenstein, was sharply condemned by the Working Group. Tearing down the buildings, it argued, meant a serious depreciation of one of the Bijlmer's distinctive features: "the demolition of Geinwijk and Gerenstein is in fact the destruction of the unique multi-ethnic society." In a report, the Working group pointed at the hidden socio-political agenda behind the renewal plans, suggesting that the authorities wanted to replace the present (largely poor black) population with rich, white people. Secondly, it argued that the Steering Committee, by favoring the demolition of the two apartment buildings, merely tried to secure a substantial piece of land for building expensive new homes."

Emphasizing that many residents had developed an affective relationship with the Bijlmermeer, the Working Group fervently disagreed with the idea of demolition as the basis of the renewal plans: "Many residents love the Bijlmer and they are therefore very emotionally involved in everything that means a threat to its continued existence." More specifically, it acknowledged the great value some residents attach to the Bijlmer's original town planning concept, in particular the huge green areas and its unique urban spaciousness, as evidenced by the distances between apartment buildings, the extended vistas and the great panoramas from the top floor apartments. The Working Group blamed the local authorities for not showing much sensibility for these exceptional features. It strongly favored a threefold approach: the completion of the Bijlmer's design as originally planned, pragmatic solutions to the management concerns and the launching of a sustained effort aimed at the Bijlmer's social renewal. Only if after the implementation of these measures specific problems persisted, it ought to be investigated whether demolition might be a valid option."

The Working Group's plea failed to garner sufficient backing, for in July 1992 the neighborhood council ratified the proposal to demolish $25 \%$ of the high-rise apartment buildings. Amazingly enough, however, the debate received an entirely unanticipated impulse when in October 1992 a big cargo jet crashed in the Bijlmer, killing forty-one people, most of them crew members and residents, and partly destroying two apartment buildings. Martin Mulder, at that time director of the Project Bureau for the Renewal of the Bijlmermeer, summarized the reactions to the crash as follows:

The Bijlmer crash has been extrenely important. After this, half of the people said: 'This is so sad. we should stop the demolition process immediately.' while the other half said: 'Now we definitely have to pursue the demolition process.' Because of the media attention for the disaster, the whole world suddenly was a witness of the Bijlmer problems. But the media also spotlighted the intriguing side of the Bijlmer community, the particular value of its multicultural society. 
Evidently, the disaster shocked everyone, especially because it proved difficult to ascertain who exactly had lived in the buildings that were partially destroyed. Many press publications after the disaster focused on the Bijlmer's many unemployed residents, as well as on its high number of illegal immigrants."

In the wake of the crash the Working Group argued in the neighborhood newspaper, called "De Nieuwe Bijlmer" (The New Bijlmer), that the disaster should have concrete implications for the renewal plans. It claimed that the decisions made so far had to be reconsidered, arguing for a period of two years in which the renewal plans would have to be reevaluated:

After the disaster. which, apart from immense sorrow, calused the demolition of nearly three hundred apartments, nobody can pretend if nothing has happened. ... In our view, the decision to demolish Geinwijk and Gerenstein needs to be revoked or postponed.'"'

According to Toon Borst, community worker, the disaster and the resultant attention for the Bijlmer in the national press had revealed that members of different ethnic groups succeeded quite well in living together in the Bijlmer. The neighborhood should therefore be seen as an example of a multicultural society, one that should not be torn apart by rivaling views on the demolition of some of its apartment buildings. Im: In response to the crash, Mulder deferred the discussion for a month, after which he argued in a report to favor a continuation of the planning process."

In this phase, planners, politicians, the housing corporation and investors gradually came to see demolition as the only solution to the financial and social problems the Bijlmer was posing in their opinion. In their view, the Bijlmer had failed. They regarded the Bijlmer as an unsafe area with many social problems. Only if various elements of the existing town planning structure were radically altered, a new perspective could be offered to the Bijlmer residents and housing corporation Nieuw Amsterdam. Therefore, they proposed a number of interventions that implied the abolition of the overall concept of the Bijlmer. Although the proposal to demolish apartment buildings meant a radical break with the town planning tradition of the Bijlmer, the aim of improving the community - its cohesion and identity - through concrete interventions is a crucial characteristic of the utopian tradition in town planning. The longing for stable community life is still an important underlying element in almost any sociotechnical redesign effort. In this way, ironically perhaps, a core value of the utopian tradition persists in the renewal of the Bijlmermeer.

In the early 1990s, the idea of demolition gained such momentum that it became difficult to stop it for those who opposed it. But, paradoxically, the demolition plans would have moved ahead much more swiftly if the dramatic airplane crash had not called attention to the Bijlmer's overall vulnerability. In the arguments of Bijlmer residents, the apartment buildings became linked to the multicultural identity of the district. In this way, the negative image of the Bijlmer, reconfirmed in many press reports after the disaster, was counterbalanced by an image that emphasized the significance of the Bijlmer's unique multicultural community - a significance that reflected larger cultural changes and anxieties in Dutch society during the early 1990s. 
The appeal to the multicultural community spirit in the Bijlmer, a value that was shared by the residents as well as the authorities, briefly halted the renewal process, made the Bijlmer temporarily more obdurate in the wake of the crash. But once the dust had settled, and the decision was made to actively pursue renewal again, a new chapter in the Bijlmer's history had already begun.

\section{Intervening in the established town planning structure: Abandoning or preserving a tradition? (1992-1998)}

After 1992, as the renewal effort accelerated and more and more plans left the drawing table, the original Bijlmer concept continued to be under attack. The structural plan for the renewal of the Ganzenhoef section of the neighborhood became available in 1993. Two years later the demolition of the Geinwijk building started, followed by the Gerenstein building in 1996. Moreover, in 1995 a project group had been set up to work on renewal plans for Kraaiennest, a third area that would be redesigned.

In response to the renewal plans, though, Bijlmer residents continued to show their involvement by establishing new working groups or unfolding other initiatives. In 1994, for instance, the Bijlmer Museum Foundation was set up to ensure the preservation of the original concept. In 1996, the Black Council was founded out of discontent with the way the (socio-economic) renewal of the Bijlmermeer was organized. In the meantime, town planners and politicians, who were convinced of the necessity to rearrange the Bijlmer, failed to agree on the overall spatial renewal strategy: Should the Bijlmer be changed in small steps, one section after the other (ad hoc renewal), or would it be best to work with a new masterplan? In this phase, the persistence of the traditional Bijlmer concept was highlighted in two specific discussions: the debate among town planners and politicians on a new masterplan and the effort of Bijlmer Museum Foundation, aimed at the preservation of the Bijlmer's original structures.

\section{The role of rigorous consistency in the renewal plans}

The town planners, architects and politicians that became involved in making new spatial plans for the Bijlmer could hardly ignore the original town planning concept. Town planners and politicians agreed that the existing spatial structures had to be changed, but their views of the proper strategies for reaching this goal differed. Some emphasized the necessity of making a new overall town plan for the Bijlmermeer; others were in favor of dividing the Bijlmermeer in smaller sections that could be changed on a case-by-case basis. The first concrete renewal operation involved the demolition of the apartment buildings Geinwijk and Gerenstein in the Ganzenhoef area, supervised by town planner Donald Lambert. He knew that housing corporation Nieuw Amsterdam advocated the building of low-rise single family homes. However, while the planning was underway, Lambert introduced an alternative type of housing: mid-rise apartment blocks. Although it looked like a risky undertaking, Lambert insisted on a smooth transition between the existing high-rise apartment buildings and 
the new low-rise sections. In his reasoning, motivated by sociopolitical concerns, the high-rise buildings and the low-rise single family homes represented two opposite social ranks or ideologies, which, preferably, were mediated by a third type of housing, spatially situated in between the two (see Figure 5.7)."

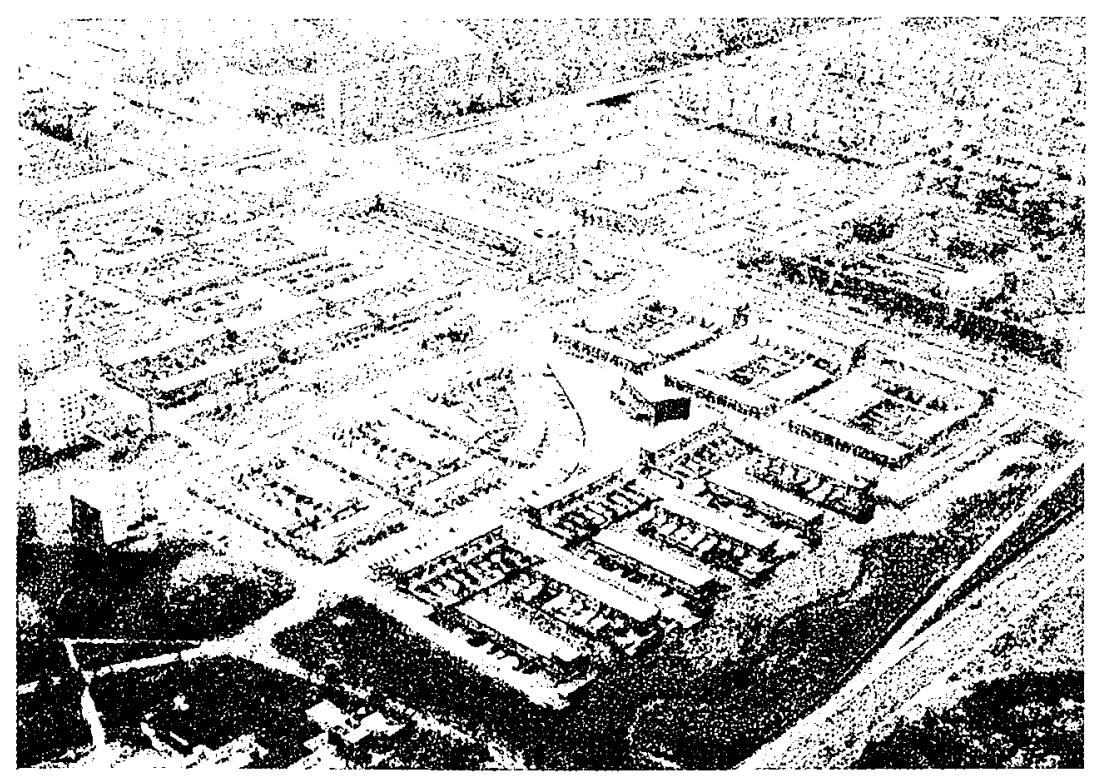

Figure 5.7: Gerenstein: low-rise area and "fit-in modules" (left) (April 1999)

Source: Archive Stedelijke Woningdienst Amsterdam 1 Stedelijke Woningdienst Amsterdam

Although Lambert's plan meant a radical break with the Bijlmer's overriding tradition of high-rise apartment blocks and egalitarianism, he also tried to establish continuities with the original Bijlmer plan by sticking to a large-scale set-up, an orthogonal grid structure and large areas of green public space between the buildings. Lambert regretted, though, that the overali concept of the Bijlmer was undermined by the introduction of completely different styles of building, designed by different architects for different parts of the Bijlmer. He argued that the city, the neighborhood council and the housing corporation could simply not reach agreement on the new structure of the Bijlmer. These parties had decided not to change the whole area at once and first concentrate on the Ganzenhoef section only, yet this decision was heavily criticized by Lambert who felt that the "ensemble" of the Bijlmer could not be renewed on an ad hoc basis. "1't Thus the value of consistency in town planning was strongly advocated by Lambert. When he suggested a plan should be drawn up that could also be applied to a larger part of the Bijlmermeer, 
...there proved to be no way of sustaining it. Politically there was no inclination to deal with the Bijlmer at such a fundamental level. (...) The major fear at that time was monotony, which many felt was the Bijlmer's undoing: there was a concern that our new "design layer" which addressed the Bijlmer as a whole, would ring in a new wave of monotony."

According to Lambert it was a political problem. To make the problem manageable, politicians drew a boundary around the Ganzenhoef area. Lambert saw this as a very arbitrary move because it cut straight through existing apartment buildings. He characterized it as an insensitive political gesture, betraying no concern for what constitutes, in essence, a town plan."

From the early 1990s on, some articulated the view that a new overall town plan was needed." ${ }^{\prime \prime \prime}$ Yet, efforts to develop such a masterplan seemed far from successful. Many individuals took part in the debate. John Westrik, for instance, in an article in the architectural magazine Archis, argued that the effort to redesign the Bijlmermeer had "failed to produce a vision, capable of guiding the spatial interventions. (...) The unique concept of the Bijlmer deserves a thorough-going urban design strategy which embraces the whole of the Bijlmer." "10

Different reasons for the difficulty of producing a new overall design have been mentioned. According to town planner Frieling, the radical nature of the Bijlmer concept itself was a reason for its endurance:

\begin{abstract}
As for the radical nature of the original Bijlmer set-up. I am inclined to say that the more one-sided the original concept, the greater its chances of survival. That's logical because the more an idea registers as an all-in scheme. the more likely it is to contain the germs of a regression toward ineffective compromise."
\end{abstract}

Igor Roovers, former project manager of Ganzenhoef also pointed at the difficulty of generating a new concept: "It was very difficult to replace the whole Bijlmer by a new concept. ... The Bijlmer was a blueprint and once it was built, it was hard to escape its concept." Bijlmermeer, argued that it proved to be very difficult to come up with a new masterplan because of the diverging viewpoints of the actors involved. Although they tried to reach agreement on a masterplan, it ultimately failed to work. Meanwhile, designated areas were selected in order to be able to proceed with the planning process." Frieling suggested that he did not believe in a masterplan for an area of such size and such a diverse population after all. It was only possible to provide the rough outlines of the planning scenarios involved."1.5

Janssen, at that time chairman of the neighborhood council, confirmed the neighborhood board's fear that the same mistake could be made as in the $1960 \mathrm{~s}$, when the Bijlmer was built. The board refused, therefore, to apply Lambert's plan for the whole Bijlmer. Janssen pointed out that there was a need to be flexible in the Bijlmer; obviously, a town plan that has only a limited reach can do less damage as well. Moreover, he favored a division of the Bijlmermeer into smaller districts that each would have their own identity. A plan based on this preference, which, paradoxically, 
might also be understood as a "masterplan" - albeit an unpretentious one, would accommodate an endless variety of small-scale planning decisions and flexible design changes."' Although city board member Louis Genet agreed with Lambert's masterplan, Janssen successfully blocked it."

Another effort to soften the Bijlmer's obduracy, and uncouple it from its CIAM moorings, was undertaken in 1994. The neighborhood council commissioned town planner and architect Ashok Bhalotra, an associate of Kuiper Compagnons, to design a structural plan for the entire renewal area. In this plan Bhalotra tried to capitalize on the positive image of the Bijlmer by defining it as a versatile, colorful and successful community that has the potential to become an attractive multicultural city. His main objective was to create a common source of inspiration and a sense of "civic pride" for its inhabitants. He conceptualized the Bijlmer population as a "border" people, as a community that is living on the boundaries of cities, neighborhoods, landscapes, nationalities and ethnicities. Bhalotra underscored the significance of distinguishing the Bijlmer as a city in which an array of cultures, economies, religions and ambitions exists side by side."

In order to allow this image to flourish, the "old modemist dogmas" had to be rejected. As Bhalotra claimed: "The utopian ideals behind the building of the Bijlmer belong to the past now: It's time people faced up to that. My theory is that you have to shake the Bijlmer to its foundations." "Is Taking the existing structure as a kind of frame for implementing new structural elements, he expressed a need for weaving new threads into the Bijlmer's urban fabric. "1" Bhaloura underlined the importance of metaphors and language in his plans: "I try to use language and the metaphors in language to free ourselves of dogmatic, technical ways of thinking ... [and] trivial clichés." inhabitants: "There are thousands of Bijlmers and thousands of Bijlmer narratives. It is interesting to integrate these thousands of narratives and perceptions in such a way that these thousand Bijlmers still go on existing." But Bhalotra also argued that in the minds of local authorities and specific groups of residents the Bijlmer concept is psychologically and culturally embedded to such extent that in the past it became very difficult for people to accept change. For one thing, a lot of courage is needed to abandon the icon of modernism, according to Bhalotra. ${ }^{122}$ In an interview in $D e$ Groene Amsterdammer, he also expressed his fascination for the modernist tradition in architecture and town planning: "Its humanistic ideological base has always appealed to me."

The renewal debates clearly revealed a deep-seated ambivalence toward "the Bijlmer tradition." Politicians, emphasizing the unsafety of the Bijlmer, wanted to break with the holistic town-planning set-up of the Bijlmer: they had no problems with ad hoc renewal. Town planners like Donald Lambert favored a break with the past by introducing an entirely new town plan based on differentiation and low-rise houses. Yet, Lambert also deliberately created continuities with the past, for instance, by sticking to an orthogonal set-up, a large scale, and large areas of public space: key elements of the original Bijlmer configuration and the modernist town planning tradition in general. Moreover, he wanted to preserve a degree of totality in the overall Bijlmer set-up, a sense of consistency, by applying his concept to the whole Bijlmer. 
Although Bhalotra's views unambiguously suggest an effort to break away from the "modernist dogmas," his plan also prioritized achieving a new sense of solidarity and community spirit, in an attempt to move away from the Bijlmer's negative stereotype.

Town planners, then, had no way of ignoring the original Bijlmer concept. Its daunting presence has been carmarked as one of the reasons for the difficulty of changing it. The sheer size of the Bijlmer largely defined the obduracy of its concept. Some town planners and politicians wanted to replace the Bijlmer's original town planning concept by another overpowering concept. Others engaged in the renewal effort favored searching a new consistency in the Bijlmer's urban design by taking a more modest approach.

\section{Preserving the Bijlmer concept: The Bijlmer Museum}

The role of the utopian, modernist town planning tradition in the attempts to preserve the obduracy of the Bijlmer was further strengthened after the establishment of the Bijlmer Museum Foundation in 1994. This Foundation was established by a group of Bijlmer residents, ${ }^{1 .+1}$ living in a number of apartment buildings in the G/K-area ${ }^{125}$ (see Figure 5.8) and supported by the resident committees of these buildings. ${ }^{120}$ Politicians and town planners mostly see this group as a small, white, intellectual, slightly elitist vanguard. ${ }^{127}$ Arguing that the town planning structure was a subject of debate only for the politicians and planners but not for the residents, the Bijlmer Museum Foundation wanted to preserve the original town planning ideas on which the design of the Bijlmer was based, as written down in the 1965 report "Grondslagen voor de Zuidoostelijke Stadsuitbreiding." The representatives of the Foundation argued that making changes in the Bijlmer's layout would not solve the neighborhood's social problems. ${ }^{129}$ Although most considered the Bijlmer in terms of its socio-economic issues and safety problems, the Foundation singled out a more positive element of the Bijlmer, namely the beauty of its design, and defined it as a "museum" that needed to be preserved. Whereas most planners and politicians saw the Bijlmer as a completed project that had not lived up to its promise, the Bijlmer Museum Foundation argued that the Bijlmer was never really finished and that it should be completed and improved according to the original plan.'"

The view that social renewal was much more essential than spatial renewal was embraced by the Black Council ("Zwart Beraad"), another group of Bijlmer residents. It aimed at representing the Bijlmer's black residents and was established in 1996 out of discontent with the way black people were excluded from the renewal effort's decision process. It was bothered by the fact that those involved in the renewal effort planning. finances, management and construction - were virtually all white, whereas most of the Bijlmer residents were black." According to Swan Tjoa, member of the Black Council and former secretary of Project Office Renewal Bijlmermeer, the logic behind the renewal plans could be characterized as a "spatial determinism," the idea that spatial interventions automatically lead to social solutions. The Black Council felt that "whoever believes that the socio-economic problem of the Bijlmer can be resolved by a few simple interventions, preferably from a spatial point of view, fails to appreciate reality. ${ }^{\prime 13}$ The Black Council argued that spatial renewal should be related as closely as possible to socio-economic renewal and a better management of the 
apartment buildings: the socio-economic renewal of the Bijlmermeer should aim primarily at stimulating the emancipatory process of the black people of the Bijlmer. ${ }^{123}$

Whereas the Black Council concentrated on social renewal, the Bijlmer Museum Foundation focused on the preservation of the main characteristics of the original design. In its effort to render the Bijlmer more obdurate. the Bijlmer Museum Foundation highlighted specific design features that were derived from the CIAM tradition. Town planner Lambert had singled out the large green public spaces and the orthogonal set-up as elements of the CIAM tradition that needed to return in a new masterplan, but the Bijlmer Museum Foundation prioritized other aspects. In its view. one of most distinctive features of the Bijlmer was the strict separation of slow and motorized traffic; since automobiles were consigned to the semi-elevated roads, the residential areas near the apartment buildings were quiet and safe. ${ }^{1: 4}$ The neighborhood's park, designed in the style of English landscape architecture and marked by slopes, crossing footpaths, imperceptible endings of watercourses, scenes and vistas. was also seen as major asset of the Bijlmermeer. ${ }^{\text {:s }}$ Bijlmer Museum proponents stressed that, "thanks to the functionalist design, the green areas form a coherent union." "The Foundation argued against the implementation of traditional residential blocks of streets with cars ${ }^{15}$; it reasoned that cars belonged exclusively on the semi-elevated roads and in the multi-story car parks, which were specifically designed for that purpose. ${ }^{13 *}$ Another important characteristic of the Bijlmer concept it wanted to preserve was the string of decentralized service areas, where shops, businesses, parkings and public transportation facilities were concentrated. Furthermore, it favored holding onto the watercourse that runs through the car-free zone and links the neighborhood to two city parks. Finally, the Bijlmer Museum Foundation found it important that, in accordance with the original plans, all residential buildings would continue to be situated within less than half a kilometer from a subway station. ${ }^{1: 4}$

As a result of its efforts, one zone has been identified in which the integrity of the original planning principles of the Bijlmer will be fully respected, even if this means restoring existing situations or realizing plans or parts thereof that were never completed. This " $\mathrm{G} / \mathrm{K}$-area" is generally seen as the one that is already most consistent with the intentions of the designers of the Bijlmer. The Bijlmer Museum Foundation has actively lobbied for creating such a zone and participated in planning the changes that are needed to make it fully compliant with the original intentions. ${ }^{1.10}$ This has led to lengthy negotiations between the Bijlmer Museum Foundation, the housing corporation, the neighborhood council and some of the other parties about issues like the exact boundaries of the "museum" zone and the proper interpretation of the original town planning principles.": 


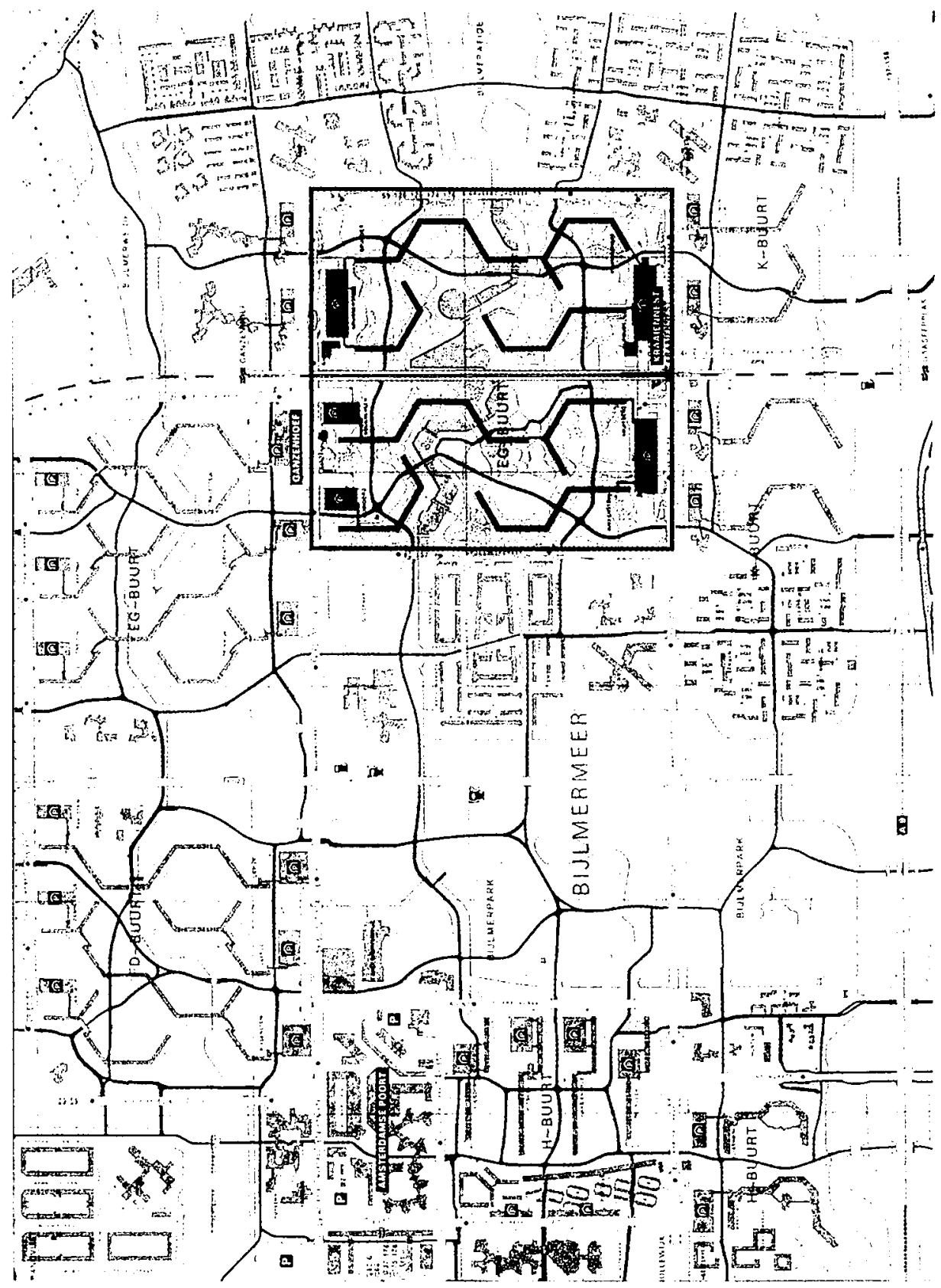

Figure 5.8: Location of Bijlmermuseum in the Bijlmermeer

Source: Geo-informatic, kartografische dienst Amsterdam (1) Geo-informatic. kurtografische dienst Ansterdam 
In 1994, a decision of the Amsterdam South-East Neighborhood Board included a section on the Bijlmer Museum, claiming that "the demolition of apartment buildings and the building of new houses concerning the area between Ganzenhoef and Kraaiennest would, in principle, not be subject to debate."1:2 There was no consensus, however, about either the exact definition of the Bijlmer Museum concept or the exact borders of the area. Problems arose when plans were made for the borders of the area. The neighborhood council decided that near the borders of the zone the design principles could be applied in a "Ienient" way. "For example, the 1996 plan for Kraiannest proposed to demolish the apartment building Koningshoef to create space for low-rise buildings, to lower one of the elevated roads and to demolish car parkings. The Foundation viewed Koningshoef as part of the Bijlmer Museum. According to George Munnik, secretary of the Bijlmer Museum Foundation, Koningshoef was, technically speaking, a good building but it was difficult to maintain. which is why Housing Corporation Nieuw Amsterdam wanted it to be demolished. ${ }^{144}$ According to the text of an address to the South-East District Council, the demolition of Koningshoef was the result of rental problems: there were many unoccupied apartments in Koningshoef and the turnover was high. It was argued that, in addition, the social safety problem in that area could not be solved if Koningshoef were to be preserved."

The Bijlmer Museum Foundation opposed the demolition of car parkings if this implied that cars could access the ground floor area near the apartment buildings. It stressed once again that the Bijlmer's most unique design principle was "the car-free, continuous residential park." It also pointed out that the easy access to public services and public transportation network in the $G / K$-area was a major asset that reflected the "successful" way in which the design principles have been applied in this specific part of the Bijlmermeer. ${ }^{1.77}$ Within the "museum" zone, parking on the ground floor level near the apartment buildings was not allowed. ${ }^{1+5}$

As my discussion suggests, the Bijlmer Museum Foundation mobilized the Bijlmer town planning tradition in its effort to prevent changes in the physical structure of the neighborhood that did not comply with the original design principles. If there were problems in the Bijlmer, it argued, they were not caused by its design. The Foundation expressed its admiration for the beauty and consistency of the Bijlmer's original design, offering a splendid alternative to the dominant "bourgeois lifestyle" associated with low-rise single family homes. As a result of its effort, at least a part of the Bijlmer will maintain its obduracy; in this zone adaptations will only be made within the town planning tadition of the Bijlmer as defined by the original town plans. Many of the other parties involved, such as planners, politicians and the housing corporation, nevertheless continued to view the Bijlmer as an unsafe, financially risky neighborhood. Their approaches suggest an ongoing effort to get rid of elements from the original Bijlmer concept by demolishing apartment buildings, lowering elevated roads, adding single family homes, destroying parkings, and so forth. Thus, for the sake of improving the neighborhood's living conditions, they were constantly looking for ways to challenge the obduracy of its urban design.

During most of the 1990s, as we have seen, the tradition of the Bijlmer concept played a major role in two discussions: the debate about a new overall masterplan for 
the Bijlmer and the discussion about the preservation of the original Bijlmer structures in the context of the Bijlmer Museum Foundation. The modernist ideas embedded in the Bijlmer structure, such as a car-free living space, separation of traffic types, egalitarianism, large areas of public space and the importance of public transportation, are still highly valued by a number of Bijlmer residents, many of whom are members of the Bijlmer Museum Foundation. Their effort has ensured that, at least for the time being, one section of the Bijlmer will live on as it was originally conceived.

\section{Obduracy and persistent traditions}

In the process of unbuilding the Bijlmermeer, the project's modernist town planning concept has been defining the parameters of the negotiations to this day. My analysis was geared toward mapping the attempts to either change or preserve the established structures. I will now return to the factor that is primarily responsible for constituting the Bijlmer's obduracy: the long-term persistence of town planning traditions. The adherence to and mobilization of the modernist, utopian tradition in town planning influenced the unbuilding process of the Bijlmer in specific ways.

First, the persistence of the utopian tradition in the discussions about the renewal of the Bijlmer explains why it proved difficult to adapt the Bijlmer. Town planners and architects involved in the renewal of the Bijlmermeer found it difficult to give up on the idea of an overall town planning concept for the Bijlmer. They valued the consistency of its rigorous concept. Its radical character has been earmarked as one of the reasons for the difficulty to change it. Minor adjustments of parts of the Bijlmer would still violate the integrity of the concept as a whole.

Second, the utopian tradition in town planning helps to explain why architects and town plamners persist in their preference for masterplans. Although architects and town planners involved in the renewal of the Bijlmermeer were prepared to abolish the CIAM principles, they tried to create an alternative kind of consistency in their new designs. Lambert deliberately created continuities with some of the guidelines of the original Bijlmer design in his town plan for Geinwijk and Gerenstein: he opted for an orthogonal large-scale set-up and large areas of green public space. The value of consistency can thus explain why certain elements of the original Bijlmer plan return in the new plans. Although local politicians were initially against all forms of masterplanning, they still invited town planner/architect Bhalotra to develop an overall structural plan.

Besides the role of consistency and masterplanning, social ideals, like constructability and community spirit, two important values of the utopian tradition. were also mobilized in the discussions about the spatial renewal of the Bijlmer. Social cohesion had to be achieved by more differentiated housing and the neighborhood's cultural identity had to be strengthened by improving the decentralized service areas. Striving for a cohesive community was a goal that was shared by politicians, town planners and residents alike, even though they differed in their choice of strategies. Residents tried to make the Bijlmer more obdurate after the 1992 jet crash by mobilizing the concept of a cohesive, multicultural community. Members of the Black 
Council recognized the utopian character of the new plans: they characterized the emphasis on spatial renewal as physical determinism and called attention to the need for social renewal.

Third, some residents view a close connection between the specific aspects of the functionalist tradition in town planning and the attractiveness of the Bijlmermeer. This is true, for instance, of the proponents of the Bijlmer Museum. They emphasized that Bijlmer residents should appreciate their living environment, its green public spaces in particular. Their concern illustrates the different implications the Bijlmer concept may have for various groups of Bijlmer residents. Although they cherished the radical nature of the concept as enabling an anti-bourgeois lifestyle, originally, of course, the Bijlmer was intended for neat. middle-class families. But from a rhetorical angle their argument was certainly productive, because as a direct result of their effort the original town planning concept will be preserved as much as possible in one part of the Bijlmer. Furthermore, the utopian tradition played a role as the basis for a thetoric of preservation of this group of "Bijlmer believers": mobilized specific characteristics of the CIAM tradition that had become embedded in the urban structures of the Bijlmer, in their attempts to preserve the Bijlmer. ${ }^{\text {s"s }}$

The central mechanism in the constitution of obduracy discussed in this chapter is the persistence of traditions in town planning; in various ways many parties have acknowledged the long-term value of the Bijlmer's town planning concept, with respect to either particular elements or the design as a whole. The mobilization of persistent traditions can explain why (design) choices are repeated over a long time. The Bijlmer case has shown that it is difficult to radically abandon an influential town planning tradition like CIAM. This differs from the role of dominant ways of thinking in the sense that all actors involved - Bijlmer residents, town planners, architects and politicians - shared the values of the modernist utopian tradition to some extent. However, the obduracy of the Bijlmer could not in all cases be explained with reference to persistent traditions. The obduracy of the semi-elevated roads in some parts of the Bijlmer, for instance, is better explained by their embeddedness in the overall traffic system of the Bijlmer as well as by financial considerations.

Having analyzed the role of obduracy in three processes of urban sociotechnical change, each one focusing on different theoretical conceptions of obduracy, it is now possible to discuss the possibility of integrating these three conceptions in one theoretical approach of urban obduracy. 


\section{Conclusions: Obduracy in Urban Sociotechnical Change}

\section{Introduction}

The central concern of this book is the tension between the effort to change cities and the obduracy of the established urban layout. My aim was to explore and gain more insight into cities as a mixture of fixed, obdurate technologies and flexible, malleable technologies. In my investigation of confrontations between "new" plans and "old" urban structures, I chose to focus on specific urban sites or structures that have become subject to what I referred to as "unbuilding activities": planning and redesign activities that are aimed at changing those elements of cities that for some reason are contested. Assuming that debates about the renewal of urban design are always infused with questions about the extent to which particular urban structures resist change, I argued that the obduracy of these structures would be "tested" in concrete efforts to "unbuild" them. Three case studies of major Dutch urban redesign projects had to provide answers to questions such as: How can cities be adapted to accommodate newly conceived ideas and policies? Why do urban structures maintain their obduracy despite efforts at urban innovation? Which strategies do special interest groups and politicians rely on when seeking to either change what seems solidly in place or hold onto what is contested?

To answer these questions, I proposed to use theoretical conceptions of obduracy that were developed mainly in the field of STS. I categorized them as four sets of conceptions of technology's obduracy: (1) material obduracy; (2) obduracy related to dominant ways of thinking and interacting; (3) obduracy explained by embeddedness; (4) obduracy as constituted by persistent (cultural) traditions. Each set of concepts focuses on different explanatory mechanisms in the constitution of obduracy. The notion of material obduracy, however, does not concur with the basic constructivist perspective of this study, since it explains obduracy with reference to intrinsic, material and formal features of (urban) technology. Claiming that obduracy cannot be solely explained by referring to material properties of technologies, I suggested that constructivist approaches - taking the "seamless web" of technology and society as a starting point - do more justice to the interwovenness of the various material and the various social, cultural, political, legal and economic aspects of the phenomenon of obduracy. This is why I argued for a "symmetrical" approach, one in which it is not assumed a priori or irrespective of contextual factors whether material 
or social factors explain the obduracy of specific urban structures. My empirical investigations subsequently addressed the role of dominant ways of thinking (Chapter 3), embeddedness (Chapter 4) and persistent traditions (Chapter 5). Each case study brought the strengths and weaknesses of these theoretical conceptions of obduracy sharper into focus.

In this final chapter, I will argue that if we are to arrive at a proper or most refined understanding of the phenomenon of obduracy in urban contexts these various conceptions of obduracy should be applied in an integrated way. I will also demonstrate how these conceptions are related to specific "unbuilding strategies" as well as to strategies geared toward preserving obduracy. I will conclude by reflecting on the third concern of this thesis, which was to draw the attention of STS scholars to the city as a major research site and, vice versa, to acquaint urban scholars with the views and methodologies of STS.

\section{Understanding obduracy}

Each of my case studies addressed one specific conception of obduracy. In this way, I was able to show that these conceptions of obduracy were specific enough to have explanatory power in a single case study. Below I will argue that, in addition, these conceptions of obduracy are compatible enough to enable a more integrated and hence more sophisticated understanding of obduracy in urban contexts. In other words, the various conceptions of obduracy that were applied to a single case study can also be used to explain different aspects of obduracy in the other two case studies. Table 6.1 provides a schematic summary of the case studies in terms of the three constructivist conceptions of obduracy.

My analysis in Chapter 3 focused on the interactions and negotiations between various actors - the ABP, the city of Utrecht, its citizens, the Railway Company and the industries fair - about the plans to redesign Hoog Catharijne. It exposed the emergence of two dominant technological frames that remained stable for a period of roughly a decade. The high inclusion of the city and the $A B P$ in their respective technological frames resulted in "closed-in obduracy," while another prominent actor, the city's residents, basically took Hoog Catharijne as a fact of life or proposed radical alternative designs, such as demolition, outside the two dominant frames (a form of "closed-out obduracy"). A newly appointed town planner supervisor, Riek Bakker, succeeded in combining elements of the two technological frames in a new design. As a result of this reconciliation, Hoog Catharijne's obduracy was overcome and the renewal effort could move forward again.

However, close attention for the "embeddedness" of Hoog Catherijne's design brings to light other aspects of its obduracy. Such explanation will stress the interwovenness of heterogeneous elements in urban structures as a major factor in preventing renewal. The embeddedness of Hoog Catharijne can be investigated, for instance, by focusing on its geographic location and its connections to the inner city. The raised walkways that link Hoog Catharijne with the inner city, which have been a significant factor in the obduracy of the complex's original design, may be explained with reference to the way the complex is tied to its surrounding urban infrastructure. 
Furthermore, its obduracy is also partly explained by its legal embeddedness in a contract between the city and building company Bredero that prohibited physical modifications that would conflict with the company's financial interests associated with the profitability of the mall.'

In Chapter 4, I used the concept of embeddedness to analyze the increasing integration of the urban section of the highway in Marastricht's overall traffic system, in the city"s larger town planning structure and in various policies and legal regulations. The conserving power of embeddedness became most clear in my analysis of how the idea of a tunnel became an integral part of municipal policies, as well as of the ideals, expectations and activities of citizens." I analyzed two different strategies that specifically addressed the highway's embeddedness: (1) deliberately ignoring embeddedness, an Open Plan Procedure technique that prompted a wide range of new design options; (2) explicitly confronting new design variants with the embedded structures by comparing the pros and cons of the various proposals.

But the role of "persistent traditions" may also be explored when trying to account for the highway's obduracy. Such approach would highlight, for instance, the tradition of tunnel engincering and the cultural values and metaphors that are associated with that tradition. In Chapter 2, I already referred to the nineteenth-century tradition of "putting the less glamorous aspects of civilization underground," a tradition that has also influenced the effort of twentieth-century architcets to solve particular redesign problems. In the discussions about the highway's redesign. the city of Maastricht supported its preference for a tumnel by suggesting it would hide the environmentally damaging flow of cars from view, an option equally favored by residents who advocated the creation of a public park to replace the old highway once it had become obsolete. This "persistent tradition" of trying to hide less attractive urban functions from view in part explains why specific types of design solutions, in this case the tunnel, are proposed and supported time and again.

In a similar vein, my analysis in Chapter 5 focused on the persistence of the utopian CIAM tradition and how its mobilization in debates and negotiations about the Bijlmer's renewal influenced the obduracy of its urban structures. Because elements of this tradition played a role for all groups involved, it would not have been productive to make a distinction between different technological frames. My analysis revealed how during the various stages of the unbuilding process the actors' repeated recourse to specific design characteristics of the CIAM tradition and shared values like community spirit, flexibility and rigorous consistency had an effect on the obduracy of the Bijlmer.

An analysis of this case in terms of dominant ways of thinking would highlight the differences rather than the similarities in the shared values of the groups of actors involved. Specifically, two technological frames or groups might be identified in the Bijlmer case: those who strongly favor the preservation of the Bijlmer's orginal structures (the so-called "Bijlmer believers") and those who view it as an unsafe neighborhood and prefer making radical design changes. In the 1970s, town planners of the Bijlmer built up a frame in which a positive view of the Bijlmer played a major role. suggesting that the renewal effort had to take place within the parameters of its original design. In the $1990 \mathrm{~s}$, one group of residents reinforced this particular frame. but at the same time, the "unsafe Bijlmer" frame gained prominence as well. The 
degrees of inclusion of various groups in these two frames structured the interactions and negotiations between the actors and explain why some actors either fiercely defended or opposed certain redesign solutions. In contrast to the Hoog Catharijne case, however, opposing technological frames did not result in a deadlock in the planning process. The frames in the Bijlmer case were also less stable and were not strictly related to the same groups of actors over time. This is why the technological frame concept is less productive in explaining the role of obduracy in this case study.

By introducing the technological frame concept in the SCOT-model. Bijker and Pinch took one step in the direction of linking technological developments to the wider cultural and socio-political context. But because of their choice to focus on widely differing technological artifacts in different historical and geographical contexts. it was hardly possible to develop more explicit connections between technological development and its cultural context. In this dissertation. I chose to limit my focus to urban sociotechnical developments in the Netherlands in one specific period of time (1960)-1990s). This made it casier to be specific and precise about the cultural and socio-political context of the developments I explored. In addition, in my analysis of obduracy it proved to be rewarding to move beyond Pinch and Bijker's exclusive focus on relevant social groups by considering, specifically in Chapter 5 , the shared cultural values that are not restricted to a single social group. This allowed me to analyze the influence of what I identified as "persistent traditions" from which no relevant social group can easily escape.

The three specific conceptions of obduracy discussed in this thesis each highlight different mechanisms in the constitution of obduracy. After having emphasized the differences and specific explanatory power of each conception and their applicability to more than one case study, it is now possible to relate the three conceptions to each other more systematically.

Sociotechnical urban structures are always embedded in a broader network of rules, plans, policies, standards, institutions and norms - a network into which they generally become even more solidly integrated over time, thus further adding to their obduracy. This process is accompanied by the building of technological frames. Such frames may also come into existence around specific plans in town planning processes. The values and meanings attributed to urban sociotechnical structures will become part of these technological frames - as is true of preferred design solutions, current policies and economic considerations - and they will also begin to play a crucial role in the negotiation process between different groups of actors about the obduracy of sociotechnical elements. When analyzing the role of obduracy, it is important to consider the degree of inclusion of the various actors in a technological frame. A high inclusion will result in closed-in obduracy, whereas low inclusion will lead to closedout obduracy. In contrast to technological frames, persistent traditions transcend local contexts, and they have a more pervasive cultural influence. Persistent traditions, shared values and collective norms influence concrete unbuilding processes to the extent that none of the actors can simply ignore what is shared, collective or persistent.

If the three conceptions of obduracy are compatible and reinforce each other in an integrated analysis, as I just argued, it should be worthwhile to analyze the role of obduracy in processes of urban sociotechnical change in single case studies by investigating to what extent the three conceptions provide a useful explanation. 
Table 6.1: Summary of the case studies in terms of the three constructivist conceptions of obduracy

\begin{tabular}{|c|c|c|c|}
\hline & $\begin{array}{l}\text { Dominant ways of } \\
\text { thinking }\end{array}$ & Embeddedness & Persistent traditions \\
\hline $\begin{array}{l}\text { Hoog } \\
\text { Catharijne/UCP }\end{array}$ & $\begin{array}{l}\text { 1988-1095: } \\
\text { Ground level frame } \\
\text { (City) versus Raised } \\
\text { level frame (ABP) (see } \\
\text { Table } 3.1 \text { ) }\end{array}$ & $\begin{array}{l}\text { - Legal embeddedness } \\
\text { of HC in a contract } \\
\text { between Bredero and } \\
\text { the city } \\
\text { - Geographical } \\
\text { embeddedness of HC } \\
\text { between inner city. } \\
\text { industries fair and rail } \\
\text { tracks }\end{array}$ & $\begin{array}{l}\text { Historical continuity } \\
\text { with the tradition of } \\
\text { "brilliant" town } \\
\text { planning ideas in the } \\
\text { city of Utrecht }\end{array}$ \\
\hline $\begin{array}{l}\text { Highway through } \\
\text { Maastricht }\end{array}$ & $\begin{array}{l}\text { 1979-1981: } \\
\text { Tunnel lrame (city } \\
\text { leadership and } \\
\text { residents) versus } \\
\text { diversion frame } \\
\text { (Rijkswalerstalat) }\end{array}$ & $\begin{array}{l}\text { - Road s integration in } \\
\text { local. national and } \\
\text { international traffic } \\
\text { schemes } \\
\text { - Embedded in town } \\
\text { planning structure and } \\
\text { ideas about cultural } \\
\text { heritage } \\
\text { - Embedded in legal } \\
\text { regulations and design } \\
\text { guidelines } \\
\text { - Embeddedness of } \\
\text { non-existent } \\
\text { technologies (the } \\
\text { tunnel) (see Figure } \\
4.10)\end{array}$ & $\begin{array}{l}\text { Tradition to hide less } \\
\text { attractive aspects of } \\
\text { civilization } \\
\text { underground (>tunnel) }\end{array}$ \\
\hline Bijlmermeer & $\begin{array}{l}\text { - Bijlmerbelievers' } \\
\text { frame (since the } 1970 \mathrm{~s}, \\
\text { first: town planners } \\
\text { and designers of the } \\
\text { Bijlmer. later Bijlmer } \\
\text { residents such as } \\
\text { Bijlmer Museum } \\
\text { Foundation) } \\
\text { - Unsafe Bijlmer' } \\
\text { frame (authorities since } \\
1980 \text { s, at its peak in the } \\
199() \text { s) }\end{array}$ & $\begin{array}{l}\text { - Semi-elevated roads } \\
\text { embedded in traffic } \\
\text { structure of the } \\
\text { Bijlmermeer } \\
\text { - Bijlmer structures } \\
\text { embedded in zoning } \\
\text { scheme (1974) }\end{array}$ & $\begin{array}{l}\text { Utopian CIAM } \\
\text { tradition: some of its } \\
\text { town planning } \\
\text { characteristics and } \\
\text { associated norms and } \\
\text { values such as } \\
\text { constructability, search } \\
\text { for community and } \\
\text { rigorous consistency }\end{array}$ \\
\hline
\end{tabular}

\section{Unbuilding strategies}

As this study has elucidated, urban renewal always involves the interplay of stasis and various intertwined, uneven processes of change. Cities are always in flux, always changing, but their embedded urban structures do not automatically change along. Although in the past decades automobile traffic significantly increased and environmental norms became stricter, the highway that divides Maastricht in two is still there; apparently. it was able to resist the various redesign efforts that were triggered by the changed local circumstances. Similarly. many people favored a radical 
redesign of some of the basic urban structures of the Bijlmer after it became a troubled neighborhood, but for various reasons it proved difficult to bring renewal plans into line with the persistent functionalist town planning norms and values embedded in its original design.

This study provides more insight into the available strategies for actors who engage in the redesign of complex urban contexts. On the basis of the four conceptions of obduracy, four "unbuilding" strategies, aimed at overcoming the obduracy of urban sociotechnology, may be identified: (1) Actors assume that material properties are the most important cause of urban technology's obduracy (material obduracy); they tend to concentrate their redesign efforts on material aspects, but this may lead to physical determinism: the conviction that "social" problems will automatically be resolved by "technical" interventions in embedded urban structures. (2) Actors acknowledge the importance of specific social groups involved in a redesign process and the possibility that their specific, potentially opposite, ways of thinking may result in obduracy; they tend to apply a combined strategy in which redesign and the attempt to inlluence the rigidity of the dominant ways of thinking involved go hand in hand. (3) Actors accept that specific urban structures do not exist in isolation and that their obduracy is associated with their embeddedness in a greater network or ensemble; they come up with an approach in which the obduracy of various embedded elements is considered and negotiated. (4) Actors recognize the importance of persistent traditions in the constitution of obduracy; they try to reduce the importance of that tradition by proposing a radical break with the past.

For a summary of the conceptions of obduracy in relation to the unbuilding strategies, see Table 6.2 .

Table 6.2: Unbuilding strategies in relation to conceptions of obduracy

\begin{tabular}{|l|l|}
\hline Unbuilding strategies & Conceptions of obduracy \\
\hline Trying to bring about material change & Material obduracy \\
\hline $\begin{array}{l}\text { Combined strategy of redesigning and trying to } \\
\text { influence the ways of thinking }\end{array}$ & Dominant ways of thinking \\
\hline $\begin{array}{l}\text { Considering and determining the obduracy of } \\
\text { integrated elements }\end{array}$ & Embeddedness \\
\hline $\begin{array}{l}\text { Strategy to reduce the importance of the tradition } \\
\text { by proposing a madical break with the past }\end{array}$ & Persistent traditions \\
\hline
\end{tabular}

The first strategy, based on a belief in physical determinism, prioritizes concrete technological interventions, assuming that social change will automatically follow. While few contemporary architects, town planners and policy makers would be inclined to embrace the idea of physical determinism, many architectural and town planning interventions have implicit or explicit social goals. In my three case studies, for instance, livability. social safety and social cohesion were among the main social goals to be achieved by material interventions. As an unbuilding strategy, this approach was most clearly visible in the Bijlmer case, where the urban renewal effort, rendered quite concrete in a new town plan, was supposed to contribute in important ways to the resolution of social and economic problems." Apparently, when the main 
target is social transformation, the utopian adagio of "salvation by bricks alone" easily comes to the fore. The disadvantage of this unbuilding strategy is that it almost exclusively considers the physical side of urban sociotechnological structures, while neglecting the social and cultural norms and values embedded in them.

Successful unbuilding strategies, it seems, pursue urban renewal at a material level as well as at a social, cultural, political and economic level. This second, potentially more successful strategy is marked by a combination of design interventions and decision process interventions that are geared toward both urban redesign and the malleability of the (rigid) viewpoints, values, and stakes of the people involved in the unbuilding process. This strategy works towards ways of achieving consensus, often by compromise. The way town planner Bakker found a solution for the deadlock in the Utrecht City Project is an example of this unbuilding strategy." She simultaneously developed a clear insight into the dominant ways of thinking of the actors involved, tried to influence these viewpoints in such a way that the actors became willing to co-operate, and developed a new, creative town plan that embodied an amalgamation of these viewpoints.

The third strategy is exemplified by the procedure used in the reconstruction process of the highway in Maastricht. The Design Workplace had to seek a design compromise that embodied a reconciliation of the viewpoints of the citizens, the city leadership, Rijkswaterstaat and the mational government without being at odds with legal norms, policies, zoning schemes and so forth. This strategy, though not exclusively geared toward changing urban design, seriously considers the embeddedness of urban structures in, for instance, urban traffic schemes, user practices and various policies. Based on this strategy, the obduracy of all the elements in the overall configuration, including their mutual interrelationship, is negotiated and eventually, albeit provisionally, evaluated. The Maastricht case has shown, however, that such consideration of the redesign effort does not guarantee a successful outcome. Instead of simplifying issues, this unbuilding strategy tends to take the various complexities into account, which in turn may complicate the unbuilding process.

At first sight, the sheer immensity of urban redesign projects that date from the 1960s - of which the Bijlmer and Hoog Catharijne are well-known Dutch examples may suggest the far-reaching malleability of urban structures. Although these plans met with resistance, their initial development and implementation took place with very little direct input from citizens. In the 1970s, however, they became more and more involved in decisions about urban renewal. The opposition of citizens, who in many cases try to preserve the obduracy of embedded urban structures, resulted in substantial delays in the decision procedures. The 1990s in particular introduced a host of new models of public participation in the Netherlands.' National and local governments tried to involve citizens in decision-making about their living environment. These models can be interpreted as ways of dealing with obduracy - as efforts to alleviate it. By involving citizens at an early stage of the decision process, policy makers and politicians hoped to raise their commitment, diminish the opposition to redesign plans and speed up the mandatory procedures.

The fourth strategy, breaking with persistent traditions as a means to overcome obduracy and bring about change. was applied in the case of the Bijlmer. Town planner Ashok Bhalotra, in charge of designing a new structural plan, explicitly 
claimed that he wanted to reject the dogmass of modernist architecture. Acknowledging that the tradition of modernist architecture was still highly valued by some Bijlmer residents as well as members of the town planning and architectural profession. Bhalotra was atware that the best way to overcome the obduracy of the Bijlmer's structures was to attack the modernist tradition and to try to diminish its influence. Another way to force a break with traditions is exemplified by a more unconscious strategy applied by those who utilize urban space. Users perform unbuilding activities by making a different use of urban structures than designers anticipated. For example, Bijlmer residents started commercial activities in the huge car parkings, and homeless people used shopping center Hoog Catharijne as a place to sleep. These local practices did question the embedded urban structures and contributed to their malleability.

\section{Strategies to preserve obduracy}

Apart from unbuilding strategies aimed at overcoming obduracy, it is also important to pay attention to the opposite: strategies to preserve obduracy. Three closely related strategies can be identified that arc often employed to preserve obduracy in cities: emphasizing continuity, age, and investment.

An important strategy actors use to preserve obduracy is to establish a continuity with the past by stressing the importance of the ideas originally embedded in urban design. All three case studies provide examples of this tactics. In the case of Hoog Catharijne, continuity was advanced as an argument to preserve the obduracy of the raised level of Hoog Catharijne and to make other parts of Hoog Catharijne malleable again. Town planning supervisor Riek Bakker emphasized the "brilliance" of the raised level design of Hoog Catharijne as a town planning concept, thereby trying to persuade the city of Utrecht to embrace the advantages of the established design as well. Suggesting her rhetorical skill, Bakker capitalized on the value of continuity in the planning history of Utrecht, its tradition of making "brilliant" town plans, and in so doing she eventually succeeded in opening up the debate about Hoog Catharijne's innovation.

In the case of the highway that cuts through Maastricht, the original town planning design of the highway as a boulevard with trees, surrounded by mid-rise, representative buildings visible from the road, was seen as a historical point of reference by the city leadership when a new design for the highway trajectory had to be developed. Also, the deliberate choice in the 1950s to make the highway part of the ring road around the city center of Maastricht was still advocated in later redesign proposals: the argument that the highway had to be used for local traffic as well.

In the Bijlmermeer, the original functionalist ideas embedded in its design were still valued by a number of Bijlmer residents and town planners engaged in its redesign. They strategically mobilized specific characteristics of its CIAM tradition. Moreover, the Bijlmer Museum Foundation actively tried to establish linkages with the past by claiming the lasting value of the Bijlmer's town planning principles. Their proposal to transform part of it into a museum proved an effective conservation strategy that raised the obduracy of part of the Bijlmer. In all three cases, the original structures were embraced as "historical exemplars" that had to be preserved or 
rehabilitated. This specific "unbuilding" strategy may serve the interests of citizens action groups, town planners, politicians, or other stakeholders in equal measure. This strategy is mainly geared toward preserving the obduracy of embedded urban structures by insisting on their lasting value.

Stressing the "age" of a particular urban design is another strategy to preserve obduracy. Designer Stuart Brand once claimed that the older a building becomes the more it is loved." These days, however, material lifecycles are being compressed all the time and buildings and urban infrastructures tend to become obsolete within an ever shorter time span. According to architect Aldo Rossi, "a city changes completely every fifty years." He even suggested that urban transformations are a condition for the persistence of a city: "A city persists through its transformations." "I" My case studies seem to confirm this trend: urban projects that were built in the 1960s already became the object of large-scale redesign efforts in the 1990s. Yet, at the same time. my case studies reveal that relatively young buildings already were tagged as monuments. In the Netherlands, buildings have to be older than fifty years to be able to obtain the official status of monument. However, many younger buildings of special importance are placed on provisional lists of monuments. Most of the apartment buildings along the highway in Maastricht are now about fifty years old and some of them have already been identified as prospective monuments. Registration as a monument generally implies a high degree of obduracy. The Bijlmer Museum, though not officially registered as a monument yet, fits this strategy as well. Moreover, in nearly all cases, a building or urban structure will be protected from radical modifications by merely calling it monumental in public. The paradox seems obvious here: our accelerated culture transforms urban structures into monuments at an ever shorter interval, but this very phenomenon. in turn, results in preservation rather than change.

A reference to the investments at stake, both in a financial and social sense, may also significantly contribute to the construction of obduracy. According to Brand, "Adaptation is easiest in cheap buildings that no one cares about." Economic and financial factors play a very important but ambiguous role in processes of urban sociotechnical change. The obduracy that results from vested interests is clearly visible in the Hoog Catharijne case, when the ABP, the owner of the mall, was not willing to give up on the raised level design because of its financial interests. But on the other hand, financial considerations (profit decline) were also an important factor in the decision to start the redesign plans, to make Hoog Catharijne malleable again. In the case of the spatial renewal of the Bijlmermeer, financial reasons (the housing corporation almost went bankrupt) also gave rise to more radical renewal plans. In many cases, however, economic interests are part of larger conflicts of interest.

Investment in social terms may also be a factor in preserving obduracy. When the "mirror trajectory" was proposed in the discussions on the reconstruction of the highway in Maastricht, one reason that this option was eventually abandoned was because this trajectory would cut through a former social problem area. Everyone agreed that the construction of a tunnel there would seriously disrupt this neighborhood's social renewal, a process that had just taken off after much effort of everyone involved. and Rijkswaterstatat therefore decided to leave it untouched. This is an example of a situation in which previous investments aimed at triggering concrete 
social improvements played a role in maintaining the neighborhood's obduracy.

To conclude, the unbuilding of cities does not only involve handling steel and concrete, but it also involves dealing with those ideas, policies, traditions and commitments that have become embedded in the sociotechnical layout of cities and that actors keep mobilizing in their attempts to either unbuild or preserve cities. This implies, on the one hand, that town planners, citizens, politicians, and action groups who want to change urban space should not underestimate the obduracy of embedded urban structures. But, on the other hand, by developing a clearer insight into the mechanisms that constitute obduracy, actors might improve their strategies for successfully addressing this phenomenon.

\section{Obduracy as construction and reality}

In accordance with the general constructivist perspective advocated in this study, I have argued that obduracy is a result or outcome of specific, interconnected processes - obduracy being the phenomenon to be explained (explanandum). Obduracy is never an intrinsic property of technology, but technologies are made obdurate. Rather than suggesting that the adoption of a social constructivist perspective implies that there is nothing "real" about technology, MacKenzie and Wajcman emphasize that the idea of the social shaping of technology "is wholly compatible with a thoroughly realist, even a materialist, viewpoint." The benefits of this constructivist approach have been argued for throughout this book. It is important, though, to point at a few differences between existing constructivist approaches of sociotechnical development and my analysis of obduracy in unbuilding processes.

In contrast to earlier STS studies that focused mainly on the process of constructing new technologies, I concentrated on the "re-construction" of existing technologies. As already indicated in Chapter 2, this is a crucial difference. In earlier SCOT-studies of sociotechnical change, the interpretative flexibility of an artifact meant that the artifact was still malleable. Closure resulted in decreasing the interpretative flexibility, after which the artifact became obdurate, if only provisionally. I have shown that in unbuilding processes, discussions, negotiations and increased interpretative flexibility are ways to put the obduracy of embedded sociotechnical ensembles under pressure, but these are not always sufficient to cancel obduracy altogether." I will give two examples. In the 1990s the Bijlmer had at least two meanings: it was seen as a functionalist, modernist neighborhood and as an unsafe, criminal and run down neighborhood. The former was relatively obdurate; after all, the Bijlmer Museum Foundation advocated its preservation and, indeed, parts of it remained obdurate. But the other Bijlmer, the unsafe neighborhood, by contrast, was very malleable, a meaning that prompted the demolition of apartment buildings and the Bijlmer's transformation into a district with single-family housing. Similarly, in the Hoog Catharijne case two dominant meanings, as embedded in two technological frames, played a role since the late $1980 \mathrm{~s}$. These two meanings remained stable for years and, as a result, Hoog Catharijne remained obdurate, despite its interpretative flexibility. Although different and even contrasting meanings can thus be attributed to a technology, this does not automatically imply its malleability. Of crucial 
importance is whether actors will finally succeed in incorporating the new meaning(s) into a new design that will accuire legitimacy.

Furthermore. On the basis of my study it seems justified to criticize the argument in constructivist technology studies that considers obduracy the outcome of a development that begins in maximum flexibility (see Chapter 2). This study has shown that the processes in which obduracy is achieved and contested are in fact much more complex. Obduracy plays a role in various interconnected processes of change, each having its own pace and actors' attempts to re-cstablish co-cvolution. This implies that obduracy is a factor at all stages of sociotechnical development. My case studies amply demonstrate that the obduracy of elements of established sociotechnical ensembles is already negotiated in the planning stage of the redesign effort. When actors finally reach agreement on, for instance, demolishing parts of a city. both obduracy and malleability are the result. Thus, my study suggests that obduracy is not only the outcome of a construction process. but also an integral part of its dynamic."

\section{STS and the city}

I want to conclude by briefly returning to my study's third concern: to bring the city into the limelight of STS. In this dissertation, I introduced the city as a hitherto neglected strategic research site in STS and I specifically relied on STS concepts to investigate a concrete dimension of urban reality. By emphasizing the heterogeneous character of the city and viewing town planning as a mode of sociotechnical change, I stressed the reciprocity of the relationship between cities and technologies, conceptualizing them as joint, interconnected categories. The STS-notions of "seamless web" and "co-evolution" have been helpful in analyzing the wide array of social, cultural, political, and economic processes of change that concurrently take place in cities all the time. Furthermore, I tried to pry open the black box of the city by focusing on some concrete urban design choices, specific ideas that became embedded in urban layouts, and actual negotiations between various groups of actors engaged in bringing about urban change.

In Chapter 3, I used the concepts of "technological frame" and "inclusion" to analyze urban change. Aibar and Bijker, in their case study of the extension plan of Barcelona, had already shown the usefulness of applying the technological frame concept to urban developments. 's Architects, town planners, civil engineers and citizens may all be included, in smaller or larger measure, in specific technological frames. I have specified the elements of the technological frames to include elements that are likely to play a role in urban contexts. Goals, key problems, problem solving strategies, user practices, and tacit knowledge are potential elements of all technological frames. On the basis of the case studies analyzed in this book, a few elements can be added that seem quite specific for cities: the crucial role of historical (town planning or architectural) exemplars, town planning design methods and criteria (including legal requirements), key problems that are associated with the town planning structure itself, current spatial policies, financial conditions and dominant prospective solutions (such as the tunnel in the case of the highway through Maastricht). 
The notion of embeddedness as one way to explain obduracy seems particularly appropriate to the city, because it captures a wide range of dissimilar, heterogeneous aspects. For one thing, the interwovennes of heterogeneous elements of various ages and scales is a crucial characteristic of the city. For the purpose of this study I limited the notion of embeddedness to urban examples: cmbeddedness in town planning structures, in a larger traffic system, in spatial policies and in legal norms and regulations. I have shown that embeddedness has a distinct financial dimension since frequently it is considered too expensive to unbuild urban structures once they have become integrated with other urban elements. Furthermore. user practices can significantly contribute to increasing the embeddedness of urban structures. Embeddedness may also have an important cultural dimension in the sense that the value attached to buidings of architectural importance often adds to the embeddedness of town planning structures.

My concept of persistent tradition, understood as a theoretical explanation of obduracy, was inspired by notions such as path dependence and technological regimes (see Chapter 2). But whereas path dependence and regimes are primarily geared toward product innovations within businesses or industries, I preferred to use a more cultural approach, specifically aimed at the analysis of continuity and change in cities. The cultural aspects of the notion of persistent tradition are not only visible in my focus on longer-term processes, on patterns in design characteristics, on the role of collectively shared rules and values, and on the aggregate level of global context, but also in how all this affects interactions and choices at the local level. The notion of persistent traditions has been made specific to the city by focusing on traditions that are crucial to urban developments, such as the tradition of modernist utopian town plamning in which values like constructability, community spirit and rigorous consistency are crucial.

My three case studies illustrate that a focus on various conceptions of obduracy, though originally not intended to be pertinent to urban sociotechnical change, lead to valuable insights when specifically applied to the city. Surely, I hope this study will encourage other STS scholars to explore the city as a strategic research site. By the same token, I would be gratified if urban scholars have become convinced that STS concepts can be especially useful when analyzing processes of urban sociotechnical change - a topic architects and urban historians have dealt with from their perspectives. This study meant to explore the possibility of connecting the hitherto largely distinct disciplinary traditions that address urban research and technological developments. In the final analysis, then, this investigation is perhaps most productively understood as a further contribution to the establishment of a common interdisciplinary playing field for these disciplines. 


\title{
Epilogue
}

After concluding my rescarch, major new developments took place in each of the three unbuilding processes I studied that underscore some of the basic conclusions of my study. These recent plans and proposals once again stress that unbuilding processes are always underway in cities and that these processes tend to be highly contingent as well. The most recent developments in the Utrecht Center Project, for instance, demonstrate that new decisions and negotiations may easily turn around the consensus on urban renewal plans reached at an earlier stage. A recent event in the case of the urban highway in Maastricht suggests that unexpected new solutions can be found by altering the "software" rather than the "hardware". The new plans for the demolition of an even greater number of apartment buildings in the Bijlmermeer, in combination with the increasing push to preserve the Bijlmer Museum section, reveals that within the same urban project some elements can become more malleable while other elements grow more obdurate.

- Utrecht, March 2000: Foundering of Utrecht's Project Provokes Bewilderment

\begin{abstract}
What was presented as a historical town planning facelift last December culminated in a debacle this Monday. After disatgreement about the costs and risks of the multimillion-guilders project. the city, NS Vastgoed. WBN fowner of Hoog Catharijne) and the Jaarbeurs ended their cooperation. It was the financing of the public space in the UCP areat, with an estimated cost of 600 million guilders, that caused the collaboration's demise. The four partners were going to contribute 360 million guilders and they expected the government to take care of the remaining 240 million. Gradually it became clear, though, that the government was only willing to allocate half of that amount ... Local politicians are left pondering how the project could founder for the third time in ten years.
\end{abstract}

In December 1999, the city council of Utrecht had given its final consent to the new UCP town plan developed under the supervision of Riek Bakker, but only three months later, in March 2000, the four partners in charge of its implementation decided to end their cooperation, a decision that seems to be directly triggered by budgetary problems. 'Meanwhile, the city leadership and the Railway Company (NS Vastgoed) chose to form a new partnership that is aimed at implementing the UCP on the basis of the Definitive Town Planning Design. Its major features regarding the redesign of the area's public space include: the demolition of the Gilden quarter and the new Railway Station Square, the recovery of the Catharijne canal and the upgrading of the railway station to a so-called Mainport public transportation facility. The two partners are seeking to enter into separate contractual agreements with the Jaarbeurs, concerning 
the redevelopment of its premises, and with WBN, with an eye to redesigning the Hoog Catharijne shopping mall." Although the partnership's break-up of March 2000 already meant a scrious blow to the renewal effort, the chances of the plan's realization became further diminished ats a result of the outcome of the local elections in the autumn of 2000 . The local party "Leefbaar Utrecht" (Liveable Utrecht), whose main goal was to prevent the execution of the Utrecht Center Project, became part of the city board alter the elections. The new board wants to consult the citizens of Utrecht about the new plans in a referendum in the summer of 2001 . These recent developments clearly illustrate the vulnerability of the decision processes that are related to large-scale urban renewal.

- Maastricht, December 1999: Congestion at A2 Suddenly Disappeared

As someone who uses the highway that cuts through Maastricht on a daily basis. I camnot believe my eyes about what is happening right now. For the past five years I spent about an hour twice a day in a traffic jam on this highway, and now. it turns out. this has been completely unnecessary all along. The solution to the traffic congestion was ... a better traffic lights regime."

Thousands of commuters arrive at their offices half an hour early, no longer frustrated by congestion, stress or wasted time. All the costly reports on the A2tunnel may well have been superfluous. That the solution to all the problems could have been so easy! Or isn'l it? ... Rijkswaterstaat does rather not respond to overly optimistic conclusions, nor does it want to cancel the tunnel plans prematurely. First. a decent investigation has to be carried out. .. A spokesperson of Rijkswaterstatat says: "Despite the startling results of the traffic lights trick, the statistics continue to tell us out that traffic will increase with a few percentages each year. Ultimately, a tunnel will be needed anyway."

Like Rijkswaterstaat, the city board of Maastricht hardly considers the new situation the end to all problems. City board member Aarts has emphasized that automobile usage will grow within the next two years, so that at some point a tunnel will be inevitable." Interestingly, a temporary solution was found that did not involve the wholesale redesign of the embedded structures of the highway - a strategy that received much attention in the past. The adaptation of the traffic lights regime involves, of course, a fairly cheap measure, one that can be implemented without interfering in the highway's immediate surroundings. Nevertheless, the city and Rijkswaterstaat still expect that a final solution can only be achieved by physical interventions in the design of the highway and its surroundings.

- Amsterdam, December 1999: Decision Made to Start More Rigorous Renewal of the Bijlmer and Demolition of Apartment Buildings

Recently, a death sentence was passed on the Bijlmermeer. The demolition of at quarter of the thiriy honeycomb-shaped apartment buildings and the renovation of some others failed to bring the improvements the Project Office Renewal 
Bijlmermeer projected in 1992. Bijlmer residents are still feeling unsafe, garbage is still spoiling the immense green areas near the apartment buildings and the car parks. elevators, galleries and shopping centers continue to be desolate spaces that seem to invite unruly behavior. A survey among Bijlmer residents pointed out that 60 to 70 percent would prefer to live in the low-rise areas that were built in between the apartment buildings in the past few years. The typical Bijlmer problems do not exist in the low-rise sections. This fact caused the Project Office and the neighborhood board South-East to decide in favor of a more rigorous renewal of the Bijlmer: to demolish another half of the remaining apartment buildings and replace them with low-rise areas. In the end, only ten of the original thirty apartment buildings will survive."

The new decision to demolish more apartment buildings has further increased the malleability of the original Bijlmermeer concept. However, two areas of high-rise buildings have been designated for preservation, one of which is the Bijlmer Museum or G/K-area." Moreover, the Bijlmer Museum has meanwhile become officially acknowledged as such in policy reports as well as in the overall planning and decision process, and therefore it has become increasingly difficult to unbuild this specific area in a radical way at some point in the future. 


\section{Notes to Chapter 1}

1. The term "unbuilding" was inspired by Donald MacKenzic and Graham Spinardi"s notion of "uninvention". MacKenzie and Spinardi introduced this notion in their work on the role of tacit knowledge in the "uninvention" of nuclear weapons (Mackenzie, 1995: 215-260). They argued that there is a general consensus that nuclear weapons cannot be uninvented: they have once come into existence and hence they will remain. Arguing that this argument rests on a traditional, cumulative view of technological development, they discussed the possibility of "uninventing" nuclear weapons. Stressing the importance of unrecorded and slowly acquired tacit knowledge in the development of nuclear weapons, they argue that, at least in theory, this knowledge may gradually disappear and hence, it will be more difficult to continue making nuclear bombs.

2. See the brochure of the city of Maastricht: "A2-Traverse Matastricht. Geen eindpunt van Nederland, maar startpunt voor Europa zonder hindernissen." Maastricht: Gemeente Maastricht, 1998 (Personal archive O. de Jong).

3. For examples of the debate in the Dutch media about spatial planning activities in the 1990s, see newspaper articles by journalists Hofland (1996), Brusse (1997), Aarden (1997) and Huisman (1999). For a recent publication contributing to the Dutch debate on spatial planning, see Hajer \& Halsema (Eds.) (1997).

4. Sec the newspaper article by Huisman (1998). For an overview and discussion of recent urban redesign ("Re-urb") projects in the Netherlands, see a publication by Crimson (an office of architectural historians) (Crimson, 1997). Examples of Dutch redesign projects in the 1990s are the three projects that are central in this dissertation: the Utrecht City Project, the reconstruction of the highway that cuts through Maastricht and the spatial renewal of the Bijlmermeer. Other examples are: the reconstruction of the city centers of Enschede. Almelo, Almere and Den Haag.

5. See, for instance. Das, Leeflang \& Rothuizen (1966) who made a plea for the urgent need to develop new, less space-consuming technologies of spatial planning and housing to be able to cope with over-population. See also a more recent publication by de Volkskrant (1997) about the boom of planning activities in the Netherlands that raises questions about whether there is enough space available. See also newspaper articles by Blokker (1997) and Hendriks \& Nijland (1996) about building underground.

6. See Holland (1996: 5).

7. See Konvitz (1985: 188).

8. Other Dutch examples of neighborhoods where CIAM principles were applied are 
Kamaleneiland in Utrecht, the village Nagele, and parts of Lelystad.

9. This version of technological determinism is derived from Mackenzic \& Wajcman (1985). For an overview of various technological detcrminist approaches, see Smith \& Marx (Eds.) (1995).

10. MacKenzic \& Wajcman (Eds.) (1985) illustrate the social shaping approach. See also the second edition of MacKenzie \& Wajcman (Eds.) (1999b), Bijker \& Law (Eds.) (1992) and Bijker. Hughes \& Pinch (Eds.) (1987). MacKenzie \& Wajcman's first edition of The Social Shaping of Techology had the polemical goal of objecting to technological determinism and presenting an alternative view of technological development in which the social, political, cultural, and economic factors shaping technology were emphasized. Their conceptualization of technology as a social construct has become widely accepted in academia; yet in the second edition of their book, the authors claim that technological determinism is still a powerful idea outside academia, notably in politics and the media. This new edition addresses more recent theoretical developments that feed on the social shaping approach. Note that actornetwork theorists (Akrich, 1992; Callon, 1986a; Latour. 1988; Law \& Mol, 1995) never made this shift to the social shaping of technology: in their theoretical framework social and technical elements are treated in a "symmetrical" fashion.

11. Sce the article by Misa (1988).

12. Such as bicycles (Bijker, 1995b), refrigerators (Schwarz Cowan, 1985), and other domestic technologies.

13. See also Wyatt (1998: 19-20), who embraces the same line of reasoning in her dissertation.

14. See Summerton (1994b: 5).

15. See Bijker (1995c: 254).

16. See Wyatt (1998: 16).

17. See MacKenzie \& Wajcman (1999a: 18).

18. See MacKenzie \& Wajeman (1999b: 18).

19. See Staudenmaier (1985: 134).

20. See Staudenmaier (1985: 156).

21. See Tarr \& Dupuy (1988a: xiii).

22. Over time, Mumford's conception of technology became increasingly complex. "Machines" refer to specific objects such as the printing press; "the machine" refers to a complex of entities including tools, machines, knowledge, skills, and arts (and, later on, even institutions); "megamachines" refer to the way in which individuals are part of large sociotechnical complexes as well. See Hughes \& Hughes (1990).

23. See Mumford (1973 (1965): 15) and Mumford (1966: 231). Sce also Mumford's work 
that deals specifically with cities (Mumford, 1961; Mumford, 1968; Mumford, 1970).

24. See Williams (1990). This image of the city as a technological, artificial environment is also present in dystopian science fiction films like Blade Rumner (Ridley Scot) and Metropolis (Fritz Lang), and in science fiction literature, as, for instance, George Orwell's 1984 and the thriller Gridirion by Philip Kerr.

25. There are a few exceptions, some of which I will discuss below.

26. See Johnson-McGrath (1997: 691).

27. See Guy, Graham \& Marvin (1997: 193).

28. See the article by Guy, Graham \& Marvin (1997). For the "invisibility" argument, sec also Graham \& Marvin (1996).

29. This distinction between the city as a locus for research and as the focus of research is derived from the work of anthropologist Ulf Hannerz (1980).

30. In his book Networks of Power (1983), Hughes analyzes the introduction of electric power systems in three citics: Chicago, Berlin, and London. He shows the importance of the urban context in the shaping of the power systems. emphasizing. for example, that the interactions involving technology at the local and regional level were more important than interactions at the national level. Decisions made by managers at the local level contributed more substantially to the shaping of the systems than the decisions made by engineers or inventors. In the period between 1890 and World War One, the major electricity companies in Germany, the United Kingdom, and the United States, focused on providing electrical power to the largest cities. In Berlin. for example, the city government in its role of regulating agency and the BEW (Berliner Elektricitits-Werke), the private company that supplied most of the city's power until 1915, were the major players in building and shaping the overall power system.

31. Sec for instance Mayntz \& Hughes (1988), La Porte (1991), and Summerton (1994a). An exception is Jane Summerton's PhD thesis on the development of a district heating system in the Swedish town Mjölby (Summerton, 1992).

32. Sec Johnson-McGrath (1997: 696).

33. It is not my intention to give a complete overview of carlier studies of city-technology relations in urban disciplines and STS. Some useful review articles on this topic have already been written: for review articles of the way urban historians deal with the rolc of technology in the city, see Konvitz, Rose \& Tarr (1990), Luckin (1991), Rosen (1989), Mochring (1990), and Johnson-McGrath (1997). See Moehring (1982) for a review of the history of public works. For a review of urban sociology see Burby \& Kaiser (1988) and Frisbic \& Kasarda (1988). See Zukin (1992) and Jacobs (1993) for a comprehensive review of qualitative, "postmodern" approaches in urban studies. For an account of the history of plamning see Burgess (1996) and Sies \& Silver (1996).

34. See Konvitz et al. (1990). Thomas Misa explains this trend toward technological determinism in urban history by suggesting that urban historians seem to have preference for doing macro level studies (Misa, 1988). Before the 1980), technological determinism was characteristic not only of urban studies, but of almost all studies of 
technology.

35. Konvity et al. (1990).

36. See Rose \& Clark (1979: 341$)$.

37. Sec Konvitz el al. (1990: 285).

38. Despite these criticisms, in the past two decades several worthwhile attempts have been made to address the relationship between cities and technology. In 1979 and 1987 for instance, the Joumal of Urban History published two special issues on "The City and Technology". Furthermore, in 1992 the Journal of Urban Technology was established, a joumal that is completely devoted to the study of technology-city relations. In 1998, the conference "Technological Futures-Urban Futures", held in Durham, England, explicitly aimed at integrating STS. LTS, and urban studies approaches.

39. See Monkkonen (1988: 159).

40. See the review article by Konvitz et al. (1990).

41. See Tarr \& Dupuy (Eds.) (1988b). See McKay (1988) on the role of supply and demand factors, cultural-aesthetic judgments regarding the new technologies, institutional arrangements and vested interests. See Suttcliffe (1988) on the role of transportation companies.

42. Sec Tarr (1984: 5).

43. In this chapter I discuss a few examples. Further interesting studies on urban sociotechnical developments include e.g. Aibar \& Bijker (1997), Summerton (1992). Hughes (1983), and Latour's Aramis, which deals with an urban public transportation system (Latour, 1996). Sec Graham \& Marvin (1996) for an explicit attempt to integrate STS (mainly SCOT) and urban studies in the analysis of urban telecommunication networks.

44. See the article by Rosen (1986).

45. Privatistic values refer to the individual's striving for wealth and personal happiness; it mainly connotes the pursuit of self-interest without being able or showing a willingness to take public interests into account.

46. See Hughes (1998: Chapter V).

47. See McShane (1994).

48. See McShane (1994: xi).

49. According to McShane, this gradual redefinition of the street as a transportation domain was strongly influenced by the introduction of faster means of transportation in the period between 1870 and 1900 (such as street railways, cable cars, and trolleys) and by the more general yet closely associated trend of suburbanization (McShane, 1994).

50. On the metaphor of "scamless web", see Hughes (1988). See also Bijker (1995b). See 
also Chapter 2.

51. Sec MacKenzic \& Wajcman (Eds.) (1985). Sec also Bijker's chapter in Handbook of Science and Technology. Studies in which he reviews the field of sociohistorical technology studies (Bijker. 1995c).

\section{Notes to Chapter 2}

1. The emphasis will be on conceptions that have been developed in STS, since the issue of obduracy of sociotechnology has been theorized most elaborately by these scholars. I limit my dicussion of urban literature in this chapter to those studies that explicitly try to conceptualize and explain the issue of obduracy in urban sociotechnical change. There is of course a whole body of literature on 'general processes of urban change. but this will not be dealt with. In this chapter. I will mainly draw on urban research in the fields of urban history and (history of) architecture and planning. My analysis of economic approaches of technology will also be restricted to studies that try to explain obduracy (by focusing on long-term patterns of change).

2. Sec a contribution by Tarr \& Konvitz (1987) to an edited volume on American urban historiography.

3. See Tarr \& Konvitz (1987: 217).

4. See Konvitz's extensive study of city building processes between the Middle Ages and the twentieth century. See Chapter 5 in particular, on urban infrastructure development (Konvitz, 1985). See also Tarr (1984).

5. See Konvitz (1985).

6. See Tarr \& Konvitz (1987).

7. Sec Konvitz (1985: 166).

8. Sec Tarr \& Konvitz (1987) and Konvitz (1985: Chapter 5).

9. They also recognize that bureaucratic regulations constrained possibilities for change (Tarr \& Konvitz, 1987).

10. Sce Trefil (1994: xiii). Trefil's book can be criticized for its universalist and positivist pretensions. According to Trefil, "cities operate according to a few well-defined laws of nature-laws that are knowable and, indeed largely known. (...) A city is a natural system. and we can study it in the same way we study other natural systems and how they got the way they are." (p. 5) In addition, Trefil makes a strict distinction between studying the science and technology aspects of cities (which is his goal) and economic, political and social aspects (which should be left to social scientists). His account of the development of cities has a distinct technological determinist overtone (which Trefil himself denies) since he emphasizes that "in the long run the changes that matter most are driven by science and technology" (p. xii).

11. See Trefil (1994: xiii). 
12. Sec Vance (1977: 6).

13. See Lynch (1990)(1958): 393).

14. A grid street pattern consists of straight lines of streets (in angles of 90 degrees) that cross over each other and thus form a series of square blocks.

15. See Lynch (1990 (1958): 384).

16. See Rossi (1982: 59).

17. See the introduction to Rossi (1982).

18. See Brand (1994: 2).

19. See Brand (1994:2)

20. In some cases, it maly indeed technically be very difficult to demolish buildings. In the summer of 1999 Dutch TV showed the fierce attempts to demolish a mausoleum in Bulgaria that was also used as a bombproof shelter. After three failed attempts to demolish the building with dynamite, it was eventually torn down stone after stone using drills.

21. It is important to distinguish the interactionist approach in STS (specifically related to technology) from more general interactionist theories that are for instance developed in political sciences and planning. Recently, some interesting Dutch PhD theses have been published in the latter fields that use a so-called "network analysis". These studies mainly focus on (the effectiveness of) urban decision making processes and the role of the various actors involved. Although these studies deal with urban change and revitalization, they do not explain or conceptualize the specific issue of technology and its obduracy. For examples, sec Smets (2000), Spaans (2000) and Kräwinkel (1997).

22. On technological frames, see Bijker (1987) and Bijker (1995b).

23. For a description of the SCOT-model see Pinch \& Bijker (1984; 1987) and Bijker (1995c).

24. Although the concept of "closure" seems to suggest that technological development is finished and that a technology will exist uncontestedly afterwards, Bijker (1995a) emphasizes that closure need not always be permanent. He introduces the concept of stabilization to stress that interpretative flexibility in fact never stops, and that we should consider "degrees of stabilization".

25. Sec Bijker (1995b: 282).

26. See Pinch \& Bijker (1987: 46).

27. Technological frames are analogous to Thomas Kuhn's paradigms and to Edward Constant's "technological paradigm" (Bijker, 1995b).

28. See Bijker (1995b: 282). 
29. See the article by Aibar \& Bijker (1997).

30. See Aibar \& Bijker (1997: 6).

31. Sce Aibar \& Bijker (1997: 17).

32. See Aibar \& Bijker (1997: 19).

33. Sec Gorman \& Carlson (1990): 156).

34. See the article by Gorman \& Carlson (1990).

35. See the article by Truffer \& Dürrenberger (1997).

36. See Truffer \& Dürrenberger (1997: 212).

37. See Ellis (1996).

38. See Ellis (1996: 265).

39. Sec Ellis (1996: 278).

40. See Birch (1982: 180).

41. Sec Birch (1982: 197).

42. See Birch (1982).

43. Sec Law (1991: 175).

44. See Mackenzic \& Wajcman (1999b) for the notion of "social shaping of technology".

45. See Bijker (1995b) who distinguishes three, increasingly radical interpretations of the seamless web metaphor: (1) the metaphor serves to remind us that nontechnical factors are important for understanding the development of technology; (2) to emphasize that it is never clear a priori and independent of context whether a problem should be treated as technical or as social; (3) to make clear that it is not enough to treat the sociotechnical as just a combination of social and technical factors but that the social and the technical are two sides of the same coin: the technical is socially constructed and the social is technically constructed.

46. The system concept is used in the Large Technical Systems (LTS) approach, introduced by Hughes (1983). The metaphor of network is introduced in the Actor Network Theory (ANT), developed by Callon (1986b) Latour (1987) and Law (1991). Bijker introduced the notion of "sociotechnical ensemble" (see e.g. (Bijker, 1995b; Bijker, 1995c)).

47. See Hughes" chapter on the relationship between his concept of "momentum" and technological determinism (Hughes, 1994).

48. See Star (1991). 
49. Sec for example work by Callon (1986b: 1987: 1991).

50. See Callon (1995).

51. Sec Latour (1988). Latour`s analysis is based on a study of Daumas.

52. See Latour (1988: 36).

53. See Lallour (1988: 37).

54. See Winner (1999 (1980): 32).

55. First, Joerges (1999) disagrees with Winner that one was obliged to use these parkways to reach the beach: There were many other roads to reach it. Sccond, the assumption that Robert Moses was a racist is contested on the basis that Moses never explicitly expressed racist opinions. Moreover. Joerges argues, there could be numerous other reasons why he built the bridges so low: financial reasons (high bridges are more expensive), the general rule that commercial traffic (like public transport) was never allowed on parkways. Moses's general focus on infrastructural adaptations in favor of the car, or aesthetic considerations. I used Winner's story as an example of a particular, influential, theoretical stance toward obduracy in STS and urban studies.

56. This cxample was studied by Schot, Hoogma \& Elzen (1994).

57. See Schot et al. (1994: 1061).

58. Later, the "control dilemma" has become known as the "Collingridge dilemma".

59. See Collingridge (1980).

60. See Law (1987).

61. See Law (1987: 113).

62. See Callon (1987).

63. See the article by Law \& Mol (1995). Although it does not harm Law \& Mol's theoretical argument, it is doubtful whether the bunkers mentioned in this article were actually built by the Nazis. It is more likely that these bunkers near Utrecht formed part of a Dutch line of defence built against possible German invasions well before World War Two. (Thanks to Marieke Kuipers.)

64. Sce Law \& Mol (1995: 279).

65. Sec Law \& Mol (1995: 280).

66. Thanks to Ger Wackers and Marieke Kuipers.

67. See Staudenmaier (1985: 197).

68. Sce Staudenmaier (1985: 197). 
69. Sec Akrich (1992). Given the semiotic, actor-network, background of this concept, it belongs in this category of embeddedness. However, Akrich`s emphasis on the ideas and worldviews of designers that are built into the design of an object fits the category of dominant ways of thinking. Bearing in mind the emphasis Akrich puts on the determining. constraining role of (the ideas that are built into) physical objects for the room for action of the users, my category of "material obduracy" would also apply.

70. See Akrich (1992: 216).

71. See Akrich (1992: 207).

72. See Mackenzic \& Wajcman (1999b: 20).

73. See Callon (1995).

74. See Callon (1995: 308).

75. See Hughes (1987).

76. See Arthur (1999 (1984)).

77. The QWERTY-keyboard is one example of patterned technological development. Is has also aspects of embeddedness, for instance its embeddedness in user practices. Other examples of patterned technological development are: increased mechanization, miniaturization of microchips, and the increased speed of computers (Mackenzic. 1995). These examples are characterized by calculable patterns that can be extrapolated towards the future. However, not all trajectories are this well circumscribed.

78. For a review of critiques of the notion of path dependence sec MacKenzie \& Wajeman (1999a). The critique comprises two claims: (1) it is not clear, but often disputed what the "best" technology is (maybe the alternatives to QWERTY are not superior); (2) if a technology has an existing alternative that is seen as better by many, it is unlikely that the "inferior" technology will survive in the end, since there are many strategies (e.g. subsidizing or offering below cost) to overcome this lock-in situation of the "inferior" technology.

79. See MacKenzie (1995: 55).

80. See Mackenzie (1995: Chapter 3) In his PhD thesis, Harro van Lente conceptualized the role of expectations and promises in technological developments (Lente, 1993).

81. See Hughes (1987).

82. See Hughes (1983: 140).

83. See Hughes (1983). Hughes (1987) and Joerges (1988) for a summary of the main concepts of the system approach.

84. See Hughes (1994).

85. Staudenmaier (1985: 154). 
86. See Hughes (1983: Chapter VI).

87. Sec Clark (1985).

88. Sec Utterback \& Suárez. (1993).

89. Sec Dosi (1982: 148).

90. Sec Dosi (1982: 152)

91. Sec Dosi (1982: 153).

92. See Nelson \& Winter (1977).

93. See Nelson \& Winter (1977: 57).

94. See Rip \& Kemp (1998: 338).

95. See Rip \& Kemp (1998: 388). See the chapter by Rip \& Kemp for a broad overview of sociological, economic and historical approaches of technological change. Rip \& Kemp situate the regime concept at the "meso-level" whereas, for example, the "script" concept is located at the "micro level".

96. See Gullberg \& Kaijser (1998). Unfortunately this unpublished conference paper is the only available piece of work on the City Building Regime approach so far.

97. Sec Gullberg \& Kaijser (1998: 5).

98. See the unpublished paper by Pinch (1999).

99. Sce Williams (1990: 16).

100. Sec Williams (1990: 206).

101. See the article by Kitt Chappell (1989). These four archetypes were: two stations in New York (Pennsylvania station (1902-1910) and Grand Central Terminal (19031913)), the Terminal Station at the World's Columbian Exposition of 1893 and Union Station in Washington D.C. (1903-1907). Kitt Chappell points out that these stations belonged to the French "Beaux-Arts" tradition, characterized by monumental features.

102. For an overview of similarities and differences between SCOT, LTS and ANT, see Bijker (1995c).

103. Recently, SCOT has come to include semiotic traits as well. See Bijker (1995b).

104. Sec Bijker (1995b).

105. Too rigid applications of the methodological rule of 'following the actors' have been criticized by e.g. Wyatt (1998). Following Wyatt's methodological principle of symmetry, I took both the actors" and my own identification of relevant actors into account. 


\section{Notes to Chapter 3}

1. A shorter version of this chapter has been published as an article (Hommels, 2000).

2. This is illustrated by a number of newspapers articles in the local and national press and letters to the press by concerned citizens, e.g. De Valk (1973). Anonymous (1973b), Anonymous (1973a). Such critical reactions were not uncommon in the 1970s. Many people protested against large-scale urban interventions that were nevertheless implemented.

3. This a quote from a newspaper article: (Anonymous, 1973a, my translation AH).

4. This discussion became particularly vehement in a decision process involving the Vredenburg concert hall. Vredenburg would form the connection between Hoog Catharijne and the inner city. Architect Herman Hertzberger made a controversial plan for the concert hall that can be seen as an architectural critique of Hoog Catharijne. lnstead of functional separation, Hertzberger emphasized multi-functionality. The chaotic low building of the concert hall contrasted sharply with the modernist. functional high-rise buildings of Hoog Catharijne (Buiter, 1993).

5. Bredero is the company that built Hoog Catharijne.

6. Sec De Valk (1973, my translation $\mathrm{AH})$.

7. See Hatagsma (1976, my tramslation AH).

8. See, e.g. newspaper articles by De Valk (1973), Halagsma (1976) and Anonymous (1978).

9. For a historical analysis of the appreciation of concrete as a building material before the 1940s, see Kuipers"s dissertation (Kuipers, 1987). For a study of the more recent appreciation (or depreciation) of concrete in buildings and Dutch architecture in general, see De Jonge (1993).

10. Other explanations circulated in those days as well. The difficulty of changing Hoog Catharijne, for instance, was ascribed to the strict terms of the contract between the city and Empeo. As a result, the change in ideas that took place in the 1970s could not be embedded in a transformed plan. It was very difficult for the city to adapt the plan in line with the new insights, if these adaptations did not concur with the profitability of Hoog Catharijne, Lid. The contract implied that any changes in the plan that would not be agreed upon by Hoog Catharijne, Ltd. would require such large financial investments of the city, that it would be forced to relinquish this attempt (Bos, Mik, \& Versnel, 1979). This explanation of the obduracy of Hoog Catharijne is in line with the notion of (legal) embeddedness, that will be elaborated in Chapter 4.

11. See Buiter (1993).

12. See a special newspaper appendix on the architects of Hoog Catharijne: (Anonymous, 1978). 
13. See Anonymous (1978).

14. Sec Anonymous (1978).

15. It has been argued before in STS that outsiders often contribute to new designs. based on completely different ways of thinking. See Chapter 2.

16. This reconstruction of the process that led to the building of Hoog Catharijne is largely based on an investigation of 1969 by Blijstra (1969), a study by Bocsenkool et al. (1983), a historical overview by Dettingmeijer (1988), a detailed overview of the history of Hoog Catharijne by historian Buiter (1993), the original Hoog Catharijne plans (N.V. Malatschappij voor Projectontwikkeling 'Empeo', 1962; N.V. Maatschappij voor Projectontwikkeling 'Empeo', 1963), and interviews with A. Feddes, chairman of the Empeo-team that designed plan Hoog Catharijne; Bunnik: 19-6-1996, and M. Dendermonde, author of a novel about the history of Hoog Catharijne and of memorial books by Bredero; Maastricht: 10-12-1997.

17. The problem of population growth in this period was, of course, not only an issue in Utrecht, but also in many other Dutch cities. See also Chapter 5.

18. See Boescnkool (1983).

19. Limiting the number of cars in the city was not considered in those days.

20. See the book by historian of architecture Michelle Provoost for examples of this practice (Provoost, 1996). Provoost's interesting study mainly focuses on the relations between infrastructure development and architecture in the city of Rotterdam.

21. See the article by De Jong (1972). The filling in of canals after World War Two did not only take place in Utrecht, but in many other Dutch cities (e.g. in Amsterdam, Amersfoort, Drachten). In the 1990s, many cities regretted the decisions taken in the 1950s and proposed to open the canals again. Sec Chapter 4 for an analysis of how the City of Maastricht dealt with increasing traffic circulation from the late 1950s onwards.

22. Intervicw Feddes.

23. Sec Buiter (1993).

24. This term will be abbreviated to NS in the rest of this chapter.

25. Interview Feddes.

26. Sec Buiter (1993).

27. See N.V. Maatschappij voor Projectontwikkeling 'Empeo' (1962).

28. See N.V. Malatschappij voor Projectontwikkeling 'Empeo' (1962).

29. See Blijstra (1969).

30. The name "Hoog Catharijne"- "hoog" meaning high—refers to the raised design at 5.5 meters above street level. 
31. Sce N.V. Maatschappij voor Projectontwikkeling 'Empeo' (1962).

32. Sec Blijstra (1969). Consequently, car traffic would not be disturbed by pedestrians.

33. See Dettingmeijer (1988) and interview Feddes.

34. Jnterview Feddes.

35. Buiter (1993) described iu delail how Plan Hoog Catharijne became accepted by the city council of Utrecht on 10 and 11 October 1963.

36. Sec Buiter (1993).

37. This term will be abbreviated as Industries Fair in this chapter. In 1995 the Industries Fair's official name was changed into Royal Dutch Jaarbeurs.

38. See Buiter (1993) and Blijstra (1969).

39. See Buiter (1993).

40. See the newspaper article by Van Esschoten \& Kragten (1987b).

41. When I use the word "partners", I refer to the city of Utrecht, the Algemeen Burgerlijk Pensioenfonds (ABP), the Royal Dutch Industries Fair and the NS.

42. See the Interim report: Gemeente Bestuur Utrecht. Algemeen Burgerlijk Pensioenfonds. Koninklijke Nederlandse Jaarbeurs, and Nederlandse Spoorwegen. "Tussenrapportage UCP." Utrecht, 1989 (Archive Stadsbalie Utrecht).

43. See Bijker (1995b), who draws on Hughes's (1983) analysis of the controversy of direct current and alternating current.

44. See Bijker (1995b: 279).

45. I have described an example of this type of stabilization process in Chapter 2. See Aibar \& Bijker (1997).

46. Minutes mecting of the Project Group UCP, 22-9-1988, my translation AH (Archive NS Vastgoed Utrecht).

47. It was important to concentrate pedestrian flows on one level, because if people would usc two levels (both the groundfloor and the raised level), the presence of people at each level would become marginal. With regard to social safety, the presence of many people was strongly preferred.

48. Sec Buiter (1993).

49. See Jacobs (1964 (1961)). For a discussion of Jacobs's ideas, see Boomkens (1998: 262-271).

50. See (Jacobs. 1964 (1961)). 
51. The 1972 exhibition at the Van Abbemuseum in Eindhoven about "the street" is one instance of this development. See Declstra et al. (1972).

52. Minutes mecting of the Project Group. 22-9-1988 (Archive NS Vastgoed Utrecht).

53. Interview E. Bolt. ABP manager; Heerlen: 9-7-1997. This analysis of "ground floor thinking" versus an emphasis on the "raised level" can also be more systematically related to specific town planning traditions. This, however, will be the focus of Chapter 5 in which I will concentrate on the role of town planning traditions in the constitution of obduracy.

54. See the "Perspectives" report: Gemeentebestuur van Utrecht. Koninklijke Nederlandse Jaarbeurs Algemeen Burgerlijk Pensioenfonds, and NV Nederlandse Spoorwegen. "Het Utrecht-City Projekt. Perspectieven voor de toekomst." Utrecht. 1989. (Archive Stadsbalic Utrecht).

55. A letter from the city board to the city commission for spatial developments and economic affairs (2"1t draft) of 24-8-1989, suggests that the reactions to the Perspectives report show that in the discussion, the contrasts between the two models were cmphasized inordinately (Archive NS Vastgoed Utrecht).

56. Interview G. Mik, city board member UCP (socialist party PvdA) (1990-1994); Utrecht: 19-6-1997.

57. A "revitalization" of the shopping center took place between 1993 and 1995. See below.

58. Interview Bolt.

59. Interview D. Regenboog, Rotterdam: 29-9-1997. Regenboog performed different functions during the history of Hoog Catharijne and UCP. He was employed by Bredero in the period between 1969 and 1976. After this, he became involved in the early phase of the UCP as a manager employed by the ABP. Then he became external project manager UCP as a Kolpron consultant (between 1991-1993). Regenboog pointed out that there were also ABP people (including himself) who wanted to combine the ground floor model and the raised floor model.

60. Interview H. van Herwaarden. NS Vastgoed; Utrecht: 1-7-1997. Van Herwaarden was also temporarily employed by the ABP.

61. Sec Douma (1998) about developments in the architecture of Dutch railway stations between 1938 and 1998. Utrecht's station hall was enlarged and redesigned in 1989 because of expected capacity problems and in 1996 because of an extension of the number of platforms.

62. See an UCP evaluation report by the NS Railway Company: "NS-evaluatie UCP rapport "Het Utrecht City Project"." Utrecht: N.V. Nederlandse Spoorwegen, 8-5-1989. By C. Douma (Archive NS Vastgoed). See also a memo by NS employee K. Peters "Enige opmerkingen bij de nota Het Utrecht City project", 5-3-1989 (Archive NS Vastgoed Utrecht).

63. Interview P. Nyst, Royal Dutch Jaarbeurs; Utrecht: 1-7-1997. 
64. Minutes Stecring Committee UCP, 24-4-1991 (Archive NS Vastgoed Utrecht).

65. On closed-in and closed-out obduracy, see Bijker (1995b) and Bijker (1995a).

66. In the period between 1989 and 1997, only minor redesign and facelifting activities took place: the redesign of the station hall in 1989 and 1996, the redesign of the pedestrian passage between the railway station and Hoog Catharijne and the "revitalization" of the shopping mall’s interior design (1993-1995) deserve mention.

67. See the Interim report: Gemeente Bestuur Utrecht, Algemeen Burgerlijk Pensioenfonds, Koninklijke Nederlandsc Jaarbeurs, and Nederlandse Spoorwegen. "Tussenrapportage UCP.” Utrecht, 1989 (Archive Stadsbalie Utrecht).

68. Idem.

69. Idem.

70. See the Project Plan UCP: Gemeente Utrecht, NV Nederlandse Spoorwegen, Algemeen Burgerlijk Pensioenfonds, and Koninklijke Nederlandse Jaarbeurs. "Projektplan UCP." Utrecht, 1991 (Archive Stadsbalie Utrecht).

71. See e.g. Minutes administrative board UCP. 12-10-1990 (Archive NS Vastgoed Utrecht).

72. Interview H.S. Yap, town planning advisor UCP (1989-1995); Den Haag: 28-9-1997. Interview by phone A. Hordijk, municipal project manager UCP, initiator of the Atelier: 18-11-1997.

73. See newspaper article (Anonymous, 1991).

74. Interview A. Bley, coordinator revitalization, WPM Beheer Midden-Nederland; Utrecht: 6-6-1997.

75. See newspaper article by Van Esschoten \& Kragten (1987a).

76. Intervicw Bolt.

77. Minutes administrative board UCP, 21-12-1992 (Archive NS Vastgoed Utrecht).

78. Gemeente Utrecht, NV Nederlandse Spoorwegen, Algemeen Burgerlijk Pensioenfonds, and Koninklijke Nederlandse Jaarbeurs. "Projektplan UCP." Utrecht, 1991 (Archive Stadsbalie Utrecht).

79. Gemeente Utrecht, NV Nederlandse Spoorwegen, Algemeen Burgerlijk Pensioenfonds, and Koninklijke Nederlandse Jaarbeurs. "Projektplan UCP." Utrecht, 1991 (Archive Stadsbalie Utrecht). Initially the NS expected an increase from 75.000 passengers a day in 1988 to 130.000 a day in 2010, but the prognoses of March 1990 expected 200.000 passengers a day in 2010 .

80. Interview Bolt. 
81. Minutes administrative board UCP, 12-9-1990 (Archive NS Vastgoed Utrecht).

82. See Gemeente Utrecht, NV Nederlandse Spoorwegen, Algemeen Burgerlijk Pensioentonds, and Koninklijke Nederlandse Jaarbeurs. "Projektplan UCP." Utrecht, 1991 ( Archive Stadsbalie Utrecht).

83. Interview Mik.

84. Although the UCP became a "potential" key project, it took a long time before it received the official key project status. Leo Lambo, secretary of the BOCP. a citizens pressure group. argues that the governmental commission that had to decide about the subsidy was not convinced by the plan. Others point out that because of a change in governmental policies after the elections the role of key projects became neglected. However, in May 1999. Deputy Minister Remkes reserved an amount of 100 to 120 million guilders from the budget for "New Key Projects" for the UCP.

85. Minutes administrative board UCP, 1-3-1993 (Archive NS Vastgoed Utrecht).

86. In the autumn of 1992 , three project developers were invited by the partners to perform a "market test" based on the Project plan. This resulted in a significant increase in the amounts of square metres offices, shops and housing that had to be provided in the UCP Master plan. See the recently published chapter on the UCP by H.S. Yap (2000). The Project plan provided $184.200 \mathrm{~m}^{2}$ office space. $12.000 \mathrm{~m}^{2}$ shops and 710 houses. whereas the Master plan had to provide 268.000-332.000 $\mathrm{m}^{2}$ office space, 23.000)$28.000 \mathrm{~m}^{2}$ shops and 945-975 houses. In later plans, these amounts increased even further (Yap, 2000: 101).

87. Stuurgroep UCP. "Masterplan Utrecht City Projekt." Utrecht: Gemeente Utrecht, 1993. (p. 15) (Archive stadsbalie Utrecht).

88. Minutes administrative board UCP, 1-3-1993 (Archive NS Vastgoed Utrecht).

89. Interview Bolt.

90. Sec the separate declaration belonging to the Master plan UCP "Verklaring behorende bij het Masterplan UCP door ABP", 15-4-1993 (Archive NS Vastgoed Utrecht).

91. Namely Mabon/Wilma. MBO and Multi Development Corporation.

92. See Ontwikkelingsmaatschappij Utrecht Centrum Project Bv. "Het ruimtelijk funktionecl concept UCP. Stap I: Evaluatic- en onderzoeksfase." Utrecht, 1995 (Archive Stadsbalie Utrecht). Various organizations and companies collaborated in designing the Spatial-functional concept: e.g. project developers, city departments of town planning and housing, and private architect offices.

93. Ontwikkelingsmaatschappij Utrecht Centrum Projekt Bv. "State of affairs", Utrecht, 1994 (p. 7) (Archive Stadsbalic Utrecht).

94. See the Spatial-functional concept: Ontwikkelingsmaatschappij Utrecht Centrum Project Bv. "Het ruimtelijk funktioneel concept UCP. Stap I: Evaluatie- en onderzoeksfase." Utrecht, 1995 (Archive Stadsbalie Utrecht). 
95. See the Spatial-functional concept: Ontwikkelingsmaatschappij Utrecht Centrum Project Bv. "Het ruimtelijk funktioneel concept UCP. Stap I: Evaluatic- en onderzocksfase." Utrecht, 1995 (Archive Stadsbalie Utrecht).

96. Interview H. Kernkamp. city board member UCP (liberal-democrat party D'66) (19941998); Utrecht: 8-7-1997.

97. (Kicrs, 1997. my translation AH). A.G. Kiers was involved as an engineer in making Plan Hoog Catharijne.

98. This committec united lobbyists and representatives of smaller activist groups from town districts, homeowners, the Union for the Protection of Pedestrians (VBV, Vereniging Bescherming Voctgangers), the Union for Public Transport Passengers (Rover), the League for the Reestablishment of Livcability (Herstel Leefbaarheid), the First Dutch Cyclists League (ENFB, Eerste Nederlandse Fietsersbond), and so on. See BOCP. "Kijk op Utrechts Centrum." Utrecht: Bewoners Overleg City Project, 1990 (Personal archive L. Lambo Utrecht). It is remarkable that residents of the Hoog Catharijne apartment buildings did not play a more prominent role in the discussions about the UCP.

99. See BOCP. “Kijk op Utrechts Centrum." Utrecht: Bewoners Overleg City Project. 1990 (Personal archive L. Lambo Utrecht).

100. See a paper in which the main viewpoints of the BOCP are summarized: BOCP. "Standpuntennota BOCP." Utrecht: Bewoners Overleg City Project, 1992 (Personal archive L. Lambo Utrecht).

101. Sec "Standpuntennota BOCP." 1992 (Personal archive L. Lambo Utrecht).

102. Interview L. Lambo, secretary BOCP; Utrecht: 29-4-1997.

103. See "Standpuntennota BOCP." 1992 (Personal archive L. Lambo Utrecht).

104. Interview Lambo.

105. See newspaper article (Anonymous, 1989).

106. Interview C. Koemans, Utrecht: 8-7-1997.

107. Interview Koemans. See also Koemans's plan: "Utrecht Catharijne Park/Stad Projekt. Een visie/plan voor de stad." Utrecht, 1993 (Personal archive C. Koemans Utrecht).

108. Sce the report that summarizes the public reactions to the UCP Master plan: "Verwerking externe konsultatierondes (inclusief inspraak) n.a.v. Masterplan Utrecht City Projekt." Utrecht: Gemeente Utrecht, 1993. Chapter 6, my translation AH (Archive Stadsbalic Utrecht).

109. Interview Kernkamp.

110. Interview J. Peters, consultant Twijnstra Gudde; Utrecht: 12-6-1997. Interview A. Lambooy, advisor Riek Bakker; Eindhoven: 26-2-1998. 
111. Intervicw Lambooy.

112. See the concept proposal to the city council of Utrecht "Utrecht Centrum Project/Intentie-overeenkomst UCP" 1996 (Personal archive L. Lambo Utrecht).

113. See Bakker's inaugural address: (Bakker, 1998: 21-22)

114. Bakker and her company BVR were responsible for the town planning aspects of the new plan, whereas consulting company Twijnstra Gudde was in charge of the procedural aspects.

115. Interview R. Bakker, town planning supervisor UCP (1996-present); Eindhoven: 14-81998.

116. Bertolini and Spit in their book on the redevelopment of station areas, also emphasize the progress that was made in this stage of the UCP. "... with little exaggeration, it can be said that more had been achieved in those four months than in the preceeding eight years." (Bertolini \& Spit, 1998: 97)

117. See Bestuurlijk Platform UCP. "Voorlopig stedenbouwkundig ontwerp." Utrecht: Gemeente Utrecht, 1997 (Archive Stadsbalie Utrecht).

118. Intervicw Kernkamp.

119. Interview E. Brandes, planner, city of Utrecht; Utrecht: 8-7-1997.

120. Interview G. Groener, WBN; Utrecht: 30-6-1997.

121. Interview Lambooy.

122. Interview Bakker.

123. Interview A. Smits, city project manager UCP; Utrecht: 12-6-1997. See also the interviews with van Herwaarden and with Kernkamp.

124. Intervicw Smits.

125. Interview Kernkamp.

126. Interview Kernkamp.

127. Interview Brandes.

128. This proposal had also been part of the earlier plans (Projektplan, Masterplan, Spatialfunctional concept).

129. Interview Groener.

130. See the report "Herontwikkeling Hoog Catharijne Utrecht." Den Haag: ING Vastgoedontwikkeling B.V., 1997 (Personal archive G. Groener Utrecht).

131. On mental models. see Gorman \& Carlson (1990), on worldviews see Truffer \& 
Diirrenberger (1997).

132. See note 10 .

\section{Notes to Chapter 4}

1. The highway has had different names in the course of time: (National) Highway 75 , European Highway 9 (E-9), (National) Highway 2 (A2, N2), European Highway 25 (E25).

2. Sec Provoost (1996).

3. See Ellis (1996) on the (social) construction of highways in US citics.

4. See the contribution of Angenot to the road congress (Angenot, 1948).

5. Different solutions were put forward. For example, Jokinen, an American traffic engineer made a radical plan for highways through Amsterdam that was never executed (sec Das et al. (1966)).

6. See Lange's contribution to the road congress, specifically focused on town planning aspects (Lange. 1948).

7. Rijkswaterstatit is the national governmental body for road construction and road management. It has several regional departments, including one in the Province of Limburg.

8. Interview J. Jamin. Rijkswaterstaat Limburg. highway enginecr, involved in the A2 (re)design process since the late 1950s; Maastricht: 2-2-1999. See also the memo "Notitie voor wethouder openbare werken en sport", 30-12-1974 (Archive Stadsontwikkeling en Grondzaken (SOG), "Rijksweg 75", code 1.811.111/1).

9. Interview Jamin. See also Minutes city council Maastricht, 3-6-1958. No. 10-17 (Archive Sociaal Historisch Centrum (SHC) Maastricht).

10. The views of the Chamber of Commerce on Maastricht's traffic problems at that time are illustrated in an advisory report: "Advies uitgebracht door de Kamer van Koophandel en Fabrieken voor Maastricht en Omstreken betreffende noodzakelijke verkeersvoorzieningen te Maastricht, aan zijne excellentie de Minister van Verkeer en Waterstaat en aan het Gemeentebestuur van Maastricht." Maastricht: Kamer van Koophandel en Fabricken voor Maastricht en Omstreken, 1955 (Archive SHC Maastricht).

11. Interview Jamin. Interview P. Jansen, city of Maastricht, traffic engineer; Maastricht: 43-1999. Interview T. Jenniskens, city of Maastricht, expert on Maastricht's history and culture; Maastricht: 15-4-1999.

12. My translation AH. Sec Minutes city council Maastricht, 3-6-1958, No 10-19 (Archive SHC Malastricht). 
13. My translation AH. See Minutes city council Maastricht, 7-5-1962, No. 6-3 (Archive SHC Maastricht).

14. J.J.J. van de Venne was director of Public Works in Maastricht between 1956 and 1977.

15. Sec an article by Van de Venne (1959).

16. See the text of a lecture by Van de Venne (1958: 2, my translation $\mathrm{AH}$ ).

17. Idem.

18. Minutes city council Maastricht, 3-6-1958, No. 10-25 (Archive SHC Maastricht). Sec also Van de Venne (1964al).

19. See the text of a lecture by Van de Venne (1964b: 18).

20. Minutes city council meeting Maastricht, 3-6-1958, No. 10--18 (Archive SHC Malastricht).

21. The highway through the city was part of Maastricht's urban expansion plans of 1951 and 1958. The proposal for developing the area around Highway 75 was made and unanimously accepted in the city council meeting of 14-1-1958. See Minutes city council Maastricht, 14-1-1958. No. 16 (Archive SHC Maastricht).

22. Minutes city council meeting Maastricht, 3-6-1958, No, 10-23 (Archive SHC Maalstricht).

23. Interview Jamin.

24. See the contribution of Angenot to the road congress (Angenot. 1948).

25. Idem.

26. See the 1956 Maastricht yearbook by Berggren (1956). Interview Jamin.

27. Minutes city council meeting Maastricht, 3-6-1958, No.14 (Archive SHC Maastricht).

28. See the yearbooks by Thewissen (1958) and Bruijnzecls (1960).

29. See an article by Van de Venne (1959) about traffic plans in Maastricht.

30. See Van de Venne (1964a: 165).

31. Sce the yearbook of 1969 (Essers, 1969: 32).

32. Minutes city council meeting Maastricht, 3-6-1958, No 10-21 (Archive SHC Maastricht).

33. Sec Thewissen (1958).

34. See the brochure by the city of Maastricht: "A2-Traverse Maastricht. Geen cindpunt van Nederland. maar startpunt voor Europa zonder hindernissen." Maastricht: Gemeente 
Maastricht, 1998 (Personal archive O. de Jong Maastricht). Interview O. de Jong, city of Malastricht. Department of Town Development, city coordinator of the A2-project; Maastricht: 7-5-1998.

35. Interview Jamin.

36. Interview Jamin.

37. See the architecture guide of Maastricht Architectumgids Maastricht 1895-1995 (Bisscheroux \& Minis. 1997: 80).

38. See an internal notition for the alderman Public Works and Sports, 30-12-1974 (Archive Stadsontwikkeling en Grondzaken (SOG), "Rijksweg 75", code 1.811.111/1).

39. Letter Rijkswaterstaat to Director of Public Works city of Maastricht, 1-2-1955; see also letter Rijkswaterstaat to Director of Public Works, 16-3-1955 (Archive Gemeentearchief Maastricht, Archive Afdeling Stadsontwikkeling, nr. 685 "Stukken betreffende aanleg Rijksweg 75, 1948-1955“. code 1.811.111).

40. Sec Dibbits (1965: 80).

41. In the City of Utrecht, historical canals were filled-up in the $1960 \mathrm{~s}$ to create space for traffic (sec Chapter 3). Sce Provoost (1996) for examples of this practice.

42. In Hoog Catharijne and the Bijlmermeer we see examples of this system of vertical segregation of traffic types. Sce chapters 3 and 5.

43. See the yearbook by Bruijnzecls (1960).

44. See the yearbook by Rouw (1970).

45. This is not entirely correct when considering the correspondence in 1955 betwecn Rijkswaterstaat and the city I referred to above. In a letter to the city, Rijkswaterstaat argues for a "more spacious" set-up of the town planning structure surrounding the highway. See letter Rijkswaterstatat to Director of Public Works of Maastricht, 1-21955; see also letter Rijkswaterstaat to Director of Public Works, 16-3-1955 (Archive Gemeentearchicf Maastricht, Archive Afdeling Stadsontwikkeling, nr. 685 "Stukken betreffende aanleg Rijksweg 75. 1948-1955", code 1.811.111).

46. See the report by Rijkswaterstaat Limburg about the reconstruction of the Scharnerweg intersection.: "Nota verbetering kruispunt Scharnerweg/Rijksweg 75 (Oranjeplein/Koningsplein)." Maastricht: Rijkswaterstaat directic Limburg. August 1974 (Personal archive J. Jamin Maastricht).

47. See articles in the local newspaper: Anonymous (1977b) and Anonymous (1977a).

48. Sec the report by Rijkswaterstaat Limburg "Nota verbetering kruispunt Scharnerweg/Rijksweg 75 (Oranjeplein/Koningsplein)." Maastricht: Rijkswaterstaat directic Limburg, August 1974 (Personal archive J. Jamin Maastricht).

49. Van de Venne mentioned this in a lecture. See Van de Venne (1964b). 
50. Minutes of a Public Council Conference "Beknopt verslag van de op 6 januari 1975 om 20.00 uur gehouden openbare raadsconferentie met als onderwerp Reconstructic kruispunt Scharnerweg/E-9.". 6-1-1975 (Archive SOG Maastricht, "Rijksweg 75", code $1.811 .111 / 1)$.

51. See the paper by Rijkswaterstaat about the reconstruction of the Scharnerweg $\begin{array}{lllll}\text { intersection: "Notia verbetering kruispunt Scharnerweg/Rijksweg } 75 & \end{array}$ (Oranjeplein/Koningsplein)." Maastricht: Rijkswaterstaat directic Limburg, August 1974 (Personal archive J. Jamin Maastricht).

52. See proposal to the city council of Maastricht "Reconstructie kruispunt E9/Scharnerweg en Geusseltrotonde". 25-8-1975, No. 463 (Archive SHC Maastricht).

53. See Chapter 3 for an analysis of how this shift influenced public opinion on the huge urban reconstruction project in the city center of Utrecht: Plan Hoog Catharijne. The protests against the implementation of the subway in Amsterdam are also notorious in this respect. as well as the fierce actions against the construction of a highway through a nature conservation area near Utrecht: Amelisweerd.

54. See the structural plan of the city of Maastricht: "Structuurplan Maastricht 1979." Reportno. 168 (Personal archive O. de Jong Maastricht).

55. E.g. the "declaration for the construction of international main traffic routes" $I=$ the Eroutes, including the E-9] that was signed in Geneva, 16-9-1950, stated that E-roads should by-pass built areas when they are led through eities and caluse inconvenience and dangers, that E-roads should not have level road junctions, and that intersections and traffic lights should be avoided. These rules, though not compulsory but should be observed as closely as possible. Sec internal paper Rijkswaterstaat "Notitie. E-wegen", Rijkswaterstaat directie Limburg, 13-7-1978 (Archive SOG Maastricht, "Rijksweg 75". code $1.811 .111 / 1)$.

56. Sec the city"s structural plan "Structuurplan Maastricht 1979." Reportno. 168 (Personal archive O. de Jong Maastricht).

57. See an article by Van de Venne (1962).

58. See the final repont of the Trajectory Study by Rijkswaterstaat. "A2/E9 on en in Maastricht. Tracé studie." Reportno. 169. Maastricht: Rijkswaterstaat. 1979 (Archive Rijkswaterstaat Limburg Maastricht. Afdeling Integraal Verkeer en Vervoer).

59. Namely President Rooseveltlaan, Koningsplein, Oranjeplein, Nassaulaan and Action group B4. Clean Maas Valley, Milicudefensie, Stichting Milieufederatic Limburg.

60. Letter P.J.G. Groot to the city council of Maastricht, 3-2-1975 (Archive SOG Maastricht, "Rijksweg 75", code 1.811.111/1).

61. See Appendix "Central action committee E-9 underground", August 1975 (Archive SOG Maastricht, "Rjjksweg 75”, code 1.811.111/1).

62. Two reasons were mentioned to explain this: (1) A connection to the Scharnerweg was no longer necessary because the main urban infrastructure connections were already available (namely the Noorderbrug and Europlein); (2) the accessibility of the 
Scharnerweg was guaranteed via other (projected) local infrastructure connections. See proposal to the city council of Maastricht, no. 66, 7-1-1981 (Archive SOG Maastricht, "Rijksweg 75", code 1.811 .11111 ).

63. See proposal to the city council of Maastricht, no. 66, 7-1-1981 (p. 9) and the document that summarizes the opinion of the city board of Maastricht about the Trajectory Study "Standpunt van de gemeente Maastricht op de hoorzitting gehouden door de Raad van de Waterstaat over het rapport A2/E9 in/om Maastricht", 29-4-1981 (Archive SOG Maastricht, "Rijksweg 75". code $1.811 .111 / 1$ ).

64. Interview Cremers.

65. See also "Standpunt van de gemeente Maastricht op de hoorzitting gehouden door de Raad van de Waterstaat over het rapport A2/E9 in/om Maastricht", 29-4-1981 (Archive SOG Maastricht, "Rijksweg 75", code 1.811.111/1).

66. Interview Jansen.

67. See proposal to the city council of Maastricht, no. 66, 7-1-1981 (Archive SOG Maastricht, "Rijksweg 75", code 1.811.111/1).

68. See memo "Gespreksnotitic t.b.v. periodick overleg RWS en gemeentebestuur Maastricht op 21 augustus 1979 betreffende studic "E-9 en Maastricht" (Archive SOG Maastricht. "Rijksweg 75", code 1.811.111/1).

69. Interview A. Lutters, city manager between 1977 and 1998; Maastricht: 21-7-1999.

70. Here, specific 'dominant ways of thinking' also start to play a role in this case study. The discussion about the diversion versus the tunnel can be framed in terms of two dominant technological frames: one in which the tunnel solution played a crucial role, and one in which the diversion was important. In this Chapter however, I focus on the role of embeddedness and hence I emphasize the embeddedness of these solutions, the tunnel in particular, in spatial policies and citizens' expectations and activities.

71. Interview J. Kroon, Bouwdienst Rijkswaterstaat, highway engineer involved in Trajectory/EIS study; Apeldoorn: 18-8-1999.

72. See memo "Notitie E-9 en Maastricht ten behoeve van het overleg RWS-Maastricht op 10 april 1978", Rijkswaterstaat Limburg (Archive SOG Maastricht, "Rijksweg 75", code $1.811 .111 / 1)$.

73. Letter Rijkswaterstaat to city board member Dols, 27-1-1978 (Archive SOG Maastricht, "Rijksweg 75", code 1.811.111/1).

74. Interview Jamin. I studied Jacques Jamin's personal archive that included numerous highway designs that were made for the A2 by Rijkswaterstaat in the period 1967-1993. Indeed, I found no plans for a tunnel until the "rough" 1981 tunnel designs. It is thus likely that closed tunnel variants were first investigated by Rijkswaterstaat in detail in the Working Group Tunnel Design (established in 1989) and the Trajectory/EIS study (started in 1995).

75. See the yearbook by Damoiscaux (1981). 
76. Sec "Inspraakreacties inzake de nota A2/E9 om en in Maastricht", November/December 1980 (Archive SOG Maastricht, "Rijksweg 75". code 1.811.111/1).

77. Letter of the Council for Water Works to the Minister of Transportation, 11-11-1981, my translation AH (Archive SOG Maastricht, "Rijksweg 75", code 1.811.111/1).

78. See "Vaststelling van het tracé van de rijksweg A2/E9 in Maastricht", 23-7-1982 (Archive Rijkswaterstaat Limburg Maastricht. Afdeling Integraal Verkeer en Vervoer).

79. Interview Jansen.

80. Interview Jansen. For an analysis of shifts in postwar Dutch governmental policies on traffic and mobility, sec Peters (1998).

81. Sec a report by G. van Heusden "Plan van Aanpak Tracé/Mer-procedure Rijksweg 2 Passage Maastricht." Malastricht: Projectbureau MER, 16-2-1995 (Archive Rijkswaterstaat Limburg Maastricht, Afdeling Integraal Verkeer en Vervoer).

82. Interview Cremers.

83. See a concept internal memo by P. Jansen "Concept. Stand van zaken met betrekking tot de ondertunneling van de A2 te Maastricht." Maastricht: Gemeente Maastricht, 1991 (Archive SOG Maastricht, "A2-Traverse Maastricht", code 1.811.111/1).

84. Interview Cremers.

85. Interview R. Danicls, town planner Buro 5, Maastricht: 21-4-1999.

86. Interview Cremers.

87. See e.g. "Maastricht, stad in evenwicht, balans in beweging. Hoofdpunten van het ruimtelijk en economisch beleid 1990-2000", March 1992. (p. 28) and "A2-Traverse. Voorlopige uitgangspunten en randvoorwaarden Gemeente Maastricht." Confirmed by city board 19-11-1996 (Personal archive O. de Jong Maastricht).

88. See Van der Cammen \& De Klerk (1993) on the role of legal regulations in planning in the Netherlands.

89. Sec an early draft plan "Schetsontwerp milicubouwplan stadstraverse Rijksweg 75 door Maastricht". 14-11-1978 (Personal archive J. Nakken Utrecht).

90. See article in the local newspaper Anonymous (1983).

91. Interview Kars.

92. See the yearbook by Bost (1983). Interview Kars.

93. Letter $H$. de Groot to city board of Maastricht, city council of Maastricht. Rijkswaterstaat Limburg, and the Provincial board of Limburg, 17-7-1987 (Archive SOG Maastricht. "A2-Traverse Maastricht", code 1.811.111/1). Interview Kars. 
94. See Tweede Structuurschema Verkecr en Vervoer (Ministeric van Verkeer en Waterstalat. 1988).

95. See a concept internal memo by P. Jansen (1991). "Concept. Stand van zaken met betrekking tot de ondertunneling van de A2 te Maastricht". Maastricht: Gemecnte Maastricht (Archive SOG Maastricht, "A2-Traverse Maastricht". code 1.811.111/1).

96. Interview E. Schreuders, Chamber of Commerce Maastricht and region; Maastricht, 194-1999.

97. See Van der Cammen and De Klerk (1993).

98. Letter Minister of Transportation to the Dutch Parliament, 6-3-1992 (Archive Rijkswaterstaat Limburg Maastricht, Afdeling Integraal Verkeer en Vervoer).

99. The Trajectory Law concerns the implementation or adaptation of main roads, railroads and water ways. The goal of the Trajectory Law is to combine decision making on infrastructure with spatial planning procedures and to speed up decision making procedures. For an overview of Dutch spatial planning policies, see Van der Cammen \& De Klerk (1993). Sec also Van Zundert (1996), mainly about zoning schemes and related legal planning instruments.

100. See the final report on temporary measures by Rijkswaterstaat Directie Limburg. "Tijdelijke maatregelen A2-Traverse Maastricht." Reportno. 32. Maastricht: Rijkswaterstaat, 1993 (Archive Rijkswaterstaat Limburg Maastricht, Afdeling Integraal Verkeer en Vervoer).

101. See Van Zundert (1996).

102. Letter H. Schroten to M. De Water (Chief engineer-director Rijkswaterstaat Limburg), 27-7-1992 (Archive SOG Maastricht, "Rijksweg 75", code 1.811.111/1).

103. Minutes of a mecting of Rijkswaterstaat, city of Maastricht, Chamber of Commerce, Province of Limburg, 4-2-1993 (Archive Rijkswaterstaat Limburg Maastricht, Afdeling Integraal Verkeer en Vervoer).

104. The Environmental Impact Statement was introduced in the Netherlands in 1987. Activities that require such a procedure are the development of large-scale neighborhoods, airports, railways, and installations for waste treatment (Cammen \& de Klerk. 1993).

105. Existing zoning schemes will often be modificd as part of a Trajectory/EIS-procedure.

106. Sec "Startnotitic Rijksweg 2-Passage Maastricht. Tracé/mer-studic." Reportno. 23. Maastricht: Rijkswaterstaat Directic Limburg, 1995 (Archive Rijkswaterstaat Limburg Maastricht, Afdeling Integraal Verkeer en Vervoer).

107. G. Van Heusden "Plan van Aanpak Tracé/mer-procedure Rijksweg 2 Passage Maastricht." Maastricht: Projectbureau MER, 1995. (p. 4) (Archive Rijkswaterstaat Limburg Maastricht. Afdeling Integraal Verkeer en Vervoer).

108. Letter from the mayor and city board members of Maastricht to the General Director of 
Rijkswaterstaat, 17-1-1996 (Personal archive O. de Jong Maastricht).

109. Proposal to the city council of Matastricht, "Voorstel van B\&W inzake Startnotitic MER Rijksweg 2-passage Maastricht" 13-2-1996 (Archive SOG Maastricht, "A2 Tracé-mer studic", code $1.811 .111 / 1$ ).

110. The variant above ground level was not investigated in the 1979 study, but there are drawings of Rijkswaterstaat engineer Huisinga of the early 1970s that show this design (Personal archive J. Jamin Maastricht).

111. Sec "Startnotitic Rijksweg 2-Passage Maastricht. Tracé/mer-studic." Reportno. 23. Maastricht: Rijkswaterstaat Directic Limburg, 1995 (Archive Rijkswaterstaat Limburg Maastricht, Afdeling Integraal Verkeer en Vervoer).

112. Infralab means Infrastructure Laboratory. The first experiments with the Infralab procedure in the Netherlands took place in 1994 and 1995. For an analysis of one of the first experimental Infralab procedures (about the N44 through Wassenaar), and a comparison of the ideas behind the Infralab-procedure and the SCOT-model, see Hommels (1995; 1997).

113. For a detailed overview of the first two steps in the Infralab procedure in Maastricht, see Pol \& Nägele (1996).

114. Interview J. Magnéc, ANWB (General Dutch Automobile Association); Deurne: 11-111999.

115. Interview A. Vesseur, secretary action committec "No cast variant for the A2"; Maastricht: 16-4-1999. See Newsletter "Geen Oosttracé voor de A2", September 1996. Another action committee with the same goals was "action committee Amby cast". Amby is a city district. In the course of 1997 , the diversion was not considered anymore because it would not reduce the amount of traffic at the existing passage. The liveability problem at the passage would thus not be solved. In December 1997 it was rumored that the east variant was taken into study again. This was however contradicted by Rijkswaterstaat.

116. Interview $\mathrm{O}$. Kars, resident of one of the apartment buildings near the highway since 1966. member of Interest Group City Passage; Maastricht: 15-7-1999.

117. Interview Kars.

118. Interview Kars.

119. Interview Kars.

120. The members of this interest group live in the apartment buildings near the Highway A2: Oranje residence, Oranjestate, President Rooseveltlaan, Nassaulaan, Koningsplein and a small number in city district Nazareth (interview Kars).

121. Interview Kars.

122. Interview J. Smeekes, advisor innovation trajectories, inventor of the Infralab procedure; Leidschendam: 6-7-1995. 
123. See Pol \& Nägele (1996).

124. Sec a paper by De Rooij (1994).

125. Op.cit. Smeckes, Infrablad special December 1995. A28 Infrablad. Podium voor comakers van Infralab. "Hans Smeekes, facilitator: 'Wisselwerking tussen klant en Rijkswaterstatat is enorm zingevend"." (p. 5).

126. Sec a paper by Kune \& Van Erkel (1995:6).

127. See the proceedings of the Infralab procedure in Maastricht, summarized in a report by Pol \& Näigele (1996).

128. Sec Pol \& Nägele (1996).

129. Interview F. Hendrikx. Rijkswaterstaat Limburg, project manager A2; Maastricht: 24-21999. Interview C. Konsten, former A2 senior project engineer and chair Design Workplace, Bouwdienst Rijkswaterstat; Utrecht: 20-4-1999. Interview Kroon. According to Konsten, the same is true for old trees. In other cases, however, we have seen that old trees lost their obduracy for the implementation of new infrastructure. This also applies to graveyards that sometimes become affected by infrastructural plans, despite the unwritten rule to respect them. This underlines my basic point that the obduracy of urban structures is constituted in specific local contexts and may differ over time. A graveyard that is obdurate in one context, may be malleable in another.

130. Interview Hendrikx.

131. Sce Pol \& Näigcle (1996).

132. Namely consulting company Zandvoort Ordening \& Advies.

133. Sec Tweede Structuurschema Verkecr en Vervoer (Ministeric van Verkeer en Waterstat, 1988).

134. Minutes of (sub-)Working Group Design. 30-3-1989 (Personal archive J. Jamin Maastricht).

135. Sec a report by the city board in which the "provisional starting points and conditions" for the redesign of the city passage are outlined: "A2-Traverse Maastricht. Voorlopige uitgangspunten en randvoorwaarden." Maastricht: Gemeente Maastricht, 1996 (Personal archive $O$. de Jong Maastricht). In the minutes of meetings of Rijkswaterstaat enginecrs, some people express their concerns about the ambiguity of the municipal guidelines with regard to monuments near the highway. There appear to exist several municipal lists with monuments that have a different status. Sec Minutes Mecting Bouwdienst/Rijkswaterstaat Directorate Limburg, 14-1-1997. and Minutes meeting Projectteam Bouwdienst, 4-2-1997 (Personal archive J. Nakken Utrecht).

136. Interview A. Cremers, city board member traffic and town planning (D'66), city of Maastricht (1990-1998); Beek: 14-9-1999.

137. Letter city board to Rijkswaterstaat. 12-3-1990 (Archive SOG Maastricht, "A2-Traverse 
Malstricht", code $1.811 .111 / 1)$.

138. Personal communication $O$. de Jong, city of Matastricht, Department of Town Development. city coordinator of the A2-project: Matastricht: 14-4-1999.

139. Interview J. Nakken, Zandvoort Ordening \& Advies, chairman Design Workplace: Malastricht: 28-10-1999. Interview Hendrikx.

140. See an exploratory investigation by the Enginecring Department of Rijkswaterstaat: "Rijksweg 2 Passage Malastricht. Een verkenning van integrale ontwerpoplossingen tracé- en verknopingsalternatieven (eerste concept)." Utrecht: Bouwdienst Rijkswaterstalat. 1997 (Archive Rijkswaterstaat Limburg Maastricht, Afdeling Integraal Verkeer en Vervoer).

141. See a report by the Engineering Department of Rijkswaterstaat in which the main design variants for the city passage are discussed: "Variantennota." Utrecht: Bouwdienst Rijkswaterstaat, 1998 (Archive Rijkswaterstaat Limburg Maastricht. Afdeling Integraal Verkeer en Vervoer).

142. Interview Nakken.

143. Minutes meeting Project team Bouwdienst, 22-9-1998 (Archive Rijkswaterstaat Bouwdienst Utrecht, codes T-IS, T-AL).

144. Minutes meeting Project team Bouwdienst, 22-9-1998 (Archive Rijkswaterstaat Bouwdienst Utrecht. codes T-IS, T-AL).

145. Minutes Design Workplace No. 21, 15-9-1998 (Archive Rijkswaterstaat Bouwdienst Utrecht, codes T-IS, T-AL).

146. Interview Konsten.

147. Interview Hendrikx.

148. Interview Kroon.

149. See Rijkswaterstaat information bulletin No. 4 and the press release of 4-6-1998 (Archive Rijkswaterstalt Limburg Maastricht, Afdeling Integraal Verkeer en Vervoer).

150. See Peters (1998).

151. Interview Lutters.

152. See Rijkswaterstaat information bulletin No. 5. March 1999 (Archive Rijkswaterstaat Limburg Maastricht, Afdeling Integraal Verkeer en Vervoer).

153. See proposal to the city council of Maastricht, "Gemeenteraad Maastricht behandelend begroting 1999 en meerjarenraming 2000-2002", 10-12-1998 (Personal archive O. de Jong Maastricht).

154. See concept decision of the council No. 14, 5-1-1999 Korr. Nr. 98-47416 "Vaststelling Structuurplan Maastricht 2005" (p. 9) (Personal archive O. de Jong Maastricht). 


\section{Notes to Chapter 5}

1. I use the tcrm 'constructability' to denote the typical Dutch term of 'maakbaarheid'. "Maakbaarheid" refers to the belief that social change can to a large extent be effected by government policies.

2. I will not focus on the decision process. This has been extensively analyzed by Maarten Mentzel in his dissertation (Mentzel, 1989).

3. See Koolhaas (1977: 3).

4. See an overview of the Modern Movement by historian Auke van der Woud (1983). On the role of CIAM in the Netherlands, see also Taveme (1983).

5. See the book by Larson (1993) on shifts in twentieth century architectural discourse.

6. According to Auke van der Woud, Le Corbusier's less nuanced version of the statements of the Athens congress later resulted in much criticism on CIAM as instigator of "rigorous" and "sterile" postwar town planning (Woud, van der, 1983).

7. Note that these two designs of Le Corbusier were never actually built.

8. See Neville-Sington \& Sington (1993: 78).

9. See Van der Woud (1983: 142).

10. See Achterhuis (1998). Although utopian thinking in town planning and architecture has been very influential in the Western world, unfortunately, Achterhuis does not pay attention to this in his book. For literature on utopianism in town planning and architecture, see c.g. Neville- Sington \& Sington (1993: Part II). Hall (1988), Meyerson (1961) and De Geus (1996).

11. See also Tod \& Wheeler (1979).

12. See Neville-Sington \& Sington (1993: 76).

13. See Neville-Sington \& Sington (1993: 37-38).

14. This overview of planning principles embedded in the Bijlmer structures and the societal and political backgrounds of these ideals and values is mainly based on the study by Bolte \& Meijer (1981), the book by Verhagen (1987), and De Boer \& Lambert (1987), the dissertation by Mentzel (1989), Crimson (1997: 82-95) and the original text of the Grondslagen voor de Zuidoostelijke stadsuitbreiding in which the main norms and guidelines for the Bijlmer plan were laid down: Afdeling Stadsontwikkeling. "Grondslagen voor de Zuidoostelijke stadsuitbreiding. Uitgangspunten en normen voor de stadsuitbreiding Zuidoost." Amsterdam: Gemeente Amsterdam, 1965 (Personal archive G. Munnik Amsterdam).

15. See Mentzel (1989). 
16. See e.g. the report on collective spaces in the Bijlmer by Dijkhuis et al. (1975).

17. See the Grondslagen: Afdeling Stadsontwikkeling. "Grondslagen voor de Zuidoostelijke stadsuitbreiding. Uitgangspunten en normen voor de stadsuitbreiding Zuidoost." Amsterdam: Gemeente Amsterdam, 1965 (Personal archive G. Munnik Amsterdam).

18. See Aldeling Stadsontwikkeling. "Grondslagen voor de Zuidoostelijke stadsuitbreiding. Uitgangspunten en normen voor de stadsuitbreiding Zuidoost." Amsterdam: Gemeente Amsterdam, 1965 (Personal archive G. Munnik Amsterdam, my transtation AH).

19. See Aldeling Stadsontwikkeling. "Grondslagen voor de Zuidoostelijke stadsuitbreiding. Uitgangspunten en normen voor de stadsuitbreiding Zuidoost." Amsterdam: Gemeente Amsterdam, 1965 (Personal archive G. Munnik Amsterdam). The idea of honey comb ensembles is generally not associated with the CIAM tradition.

20. See Mentzel (1989).

21. See Van der Woud (1983).

22. Sec Das, Leeflang \& Rothuizen (1966).

23. Sec the Grondslagen: Afdeling Stadsontwikkeling. "Grondslagen voor de Zuidoostelijke stadsuitbreiding. Uitgangspunten en normen voor de stadsuitbreiding Zuidoost." Amsterdam: Gemeente Amsterdam, 1965 (Personal archive G. Munnik Amsterdam, my translation $\mathrm{AH}$ ).

24. See Verhagen (1987).

25. Bolte \& Meijer (1981) mention the following 'mistakes' that had been made in the Amsterdam garden cities: too many cars were allowed in the direct living environment of citizens, areas of green public space were too scattered, and services were not concentrated.

26. Sec Bolte \& Meijer (1981).

27. Sce Mentzel (1989).

28. Sce Mentzel (1989).

29. Sec Verhagen (1987).

30. See Neville-Sington \& Sington (1993: 79).

31. See Hulsman (1999).

32. See Neville-Sington \& Sington (1993: 79).

33. See Bolte \& Meijer (1981) and Mentzel (1989). Bolte and Meijer conclude that, because of the initial postive response to the Bijlmer concept, the town plan represented consensus about the model of "the City of Tomorrow". 
34. See Ter Horst et al. (1991) and Mentzel (1989).

35. Larson (1993) identifies a second major shift in architectural discourse in this period: a postmodern reaction against modernist architecture took place between 1966 and 1985.

36. Sec the article by Stoppelenburg (1972). Bolte \& Meijer (1981) argue that the planners of the Bijlmer have nevertheless tried to incorporate a number of criticisms of functionalism in the Bijlmer design. For instance, the ideals on which the "wijkgedachte" (neighborhood unit) was based, return in the emphasis on the house blocks and collective services and spaces. In both cases, the spatial unit is also seen as a social unit.

37. See the analysis of the Bijlmer from a town planning perspective by Ter Horst et al. (1991:4).

38. See a magazine article by Luijten (1997). Others pointed out that the Bijlmer was far ahead of its time rather than being superseded by social developments. Interview D. Frieling, chairman of the Renewal Bijlmermeer Stecring Committee (1990-1992), assistant director of the Amsterdam Public Housing Department (1967-1972); Delft: 18 8-1998. Note that many of the interviewees lived for shorter and longer periods in the Bijlmermeer: John Brewster, Pi De Bruijn, Dirk Fricling, Lucas van Herwaarden, Susan van der Hilst, Ronald Janssen, George Munnik, Swan Tjoa.

39. See Melger et al. (1987: XII, my translation AH).

40. Frieling quoted by Kloos (1997: 23).

41. See De Wit (1993: 19, my translation $\mathrm{AH})$.

42. Sec Stichting Wijkopbouworgaan Bijlmermeer (1980: 5, my translation AH).

43. Sec De Wit (1993: 20, my translation AH).

44. Interview L. van Herwaarden, landscape architect, neighborhood South-East; Amsterdam: 22-7-1999.

45. Interview P. de Bruijn, architect, employee of the municipal Housing Department (1970-1977), chairman of the Bijlmermeer Management Group (1974-1977); Amsterdam: 26-8-1998.

46. Interview de Bruijn.

47. See Ter Horst et al. (1991). In The Netherlands, town planning structures are legally defined in so-called zoning plans ('bestemmingsplannen'). See Chapter 4 on the legal embeddedness of urban structures.

48. Interview de Bruijn. However, the apartment buildings that were built in the last phase deviated from the overall town planning concept of the Bijlmer (Ter Horst et al., 1991).

49. See report Stichting Wijkopbouworgaan Bijlmermeer (1980).

50. Interview R. Grotendorst, former employee of the Amsterdam Federation of housing 
corporations (1980-1984), former (assistant) director of housing corporation Nieuw Amsterdam (1984-1989 and 1989-1996); Amsterdam: 10-8-1998.

51. Melger et al. (1987) criticized this limited definition.

52. See the report by the Municipal Housing Department: Gemeentelijke Dienst Volkshuisvesting. "Concept notitic Bijlmer." Amsterdam, 1970 (Archive stadsdecl Zuidoost Amsterdam).

53. See the report by Huls et al. (1983).

54. See an investigation by Brakenhoff et al. (1991). Grotendorst pointed out that often, the immigrants were seen as the cause of the problems in the Bijlmer.

55. See the dissertation by cultural anthropologist and sociologist Livio Sansone (1992). who studied the activities of Surinam-Creole youth subcultures in the Bijlmermeer. In this culture "hosselen" is an important activity for the unemployed. To "hossel means to undertake activities in the informal economy. This includes a wide range of activities, from earning moncy by organizing small-scalc parties and festivals in Bijlmer apartment buildings and performing odd jobs for neighbors and family to outright illegal activities such as theft and drug dealing.

56. Interview Grotendorst.

57. Note that the last measure, allowing cars near the residential buildings, was already in contrast to the ideas of a car free ground floor on which the Bijlmer's design was based.

58. Sec "A Plan for the Bijlmer" by the Project Group on High-Rise Buildings in the Bijlmermeer: Projektburo Hoogbouw Bijlmermeer. "Een plan voor de Bijlmer." Amsterdam: Gemeente Amsterdam, 1983 (Archive stadsdeel Zuidoost Amsterdam).

59. Sec report by Renewal Bijlmermeer Steering Committee "Kiezen en beginnen! Eerste werkprogramma van de Stuurgroep Vernicuwing Bijlmer." Amsterdam: Stuurgroep Vernieuwing Bijlmermeer, 1991 (Personal archive $T$. van den Klinkenberg Amsterdam).

60. Grotendorst mentioned another reason: a number of planners of the Bijlmermeer were still employed by the city of Amsterdam and would not accept demolition. Interview Grotendorst.

61. Interview Grotendorst.

62. See Ter Horst et al. (1991: 33, my translation AH).

63. Interview Grotendorst.

64. See the report by Melger et al. (1987).

65. Idem.

66. See proposal to the city council of Amsterdam, 26-10-1990. No. 891. "De toekomst van de Bijlmermeer." - Personal archive T. van den Klinkenberg Amsterdam and archive 
Projectbureau Vernieuwing Bijlmermeer. See also the report by the Renewal Bijlmermeer Steering Committee. "Werk met werk maken." Amsterdam: Stuurgroep Vernieuwing Bijlmermeer, 1992 (Personal archive $T$. van den Klinkenberg Ansterdam). Interview Grotendorst; Interview Frieling. The following parties were involved in this Working Group: City of Amsterdam, housing corporation Nieuw Amsterdam. District South-East, Ministry of Public Health, Spatial Ordering and Environment. Amsterdam Federation of housing corporations, investors, National Housing Council. Netherlands Christian Institute for Housing.

67. See report Werkgroep Toekomst Bijlmermecr. "De Bijlmer blijft, veranderen." Amsterdam, 1990 (Archive stadsdeel Zuidoost Amsterdam).

68. E.g. a management plan for apartment buildings, differentiation of rents, exchanging apartment buildings with other housing corporations and so forth.

69. See report Werkgroep Toekomst Bijlmermeer. "De Bijlmer blijft, veranderen." Amsterdam, 1990. (p. 40), my translation AH (Archive stadsdeel Zuidoost Amsterdam).

70. See the planning proposal by Office for Metropolitan Architecture. "Revisie Bijlmer." Rotterdam: OMA, 1986. This plan has never been executed.

71. Interview $T$. van den Klinkenberg, member of the Renewal Bijlmermecr Steering Committee (1990-1992); Amsterdam: 25-5-1998. Interview R. Janssen, former chairman of the neighborhood council, board member neighborhood South-East (PvdA); Amsterdam: 31-7-1998. Interview M. Mulder. Director of Project Office Renewal Bijlmermeer (1992-1996): Almere: 10-8-1998.

72. Interview van den Klinkenberg.

73. See report Werkgroep Tockomst Bijlmermeer. "De Bijlmer blijft, veranderen." Amsterdam, 1990. (p. 43), my translation AH (Archive stadsdeel Zuidoost Amsterdam).

74. Interview I. Roovers, project manager Ganzenhoef (1993-1997); Almere: 25-5-1998. Interview Grotendorst. Interview D. Lambert, town planning supervisor Ganzenhoef; Rotterdam: 27-7-1998.

75. In 1987, neighborhood South-East was established as a result of the aim to decentralize municipal governance in Amsterdam. The neighborhood South-East comprises the Bijlmermeer and has its own neighborhood council and neighborhood board.

76. From now on referred to as the Steering Committee.

77. Letter Renewal Bijlmermeer Steering Committee to the city board of Amsterdam, the board of South-East and the Board and members of Housing Corporation Nieuw Amsterdam, 25-5-1992, my translation AH (Personal archive T. van den Klinkenberg Amsterdam).

78. Interview Frieling. Interview Grotendorst.

79. Later two focus areas were added: Kraaiennest and Centrumgebied Zuidoost.

80. Memo neighborhood board W+W, Nieuw Amsterdam, 2-4-1991. "Voorzet voor de 
keuze van een declgebied" (Archive Projectbureau Vernicuwing Bijlmermeer Amsterdam).

81. See the press report of 25-6-1992 "Stuurgroep Vernieuwing Bijlmermecr brengt eindrapport uit." (Personal archive T. van den Klinkenberg Amsterdam).

82. Interview Janssen. Interview Grotendorst.

83. Interview Janssen.

84. See Van Giersbergen (1997c: 27 op. cit.)

85. Interview Frieling.

86. Werkgroep Wonen en Woonomgeving Bijlmermeer. "Ganzenhoef-west: Geen vernieling, maar vernieuwing." Reportno. 30. Amsterdam: Wijkopbouworgaan Bijlmermeer, 1992. (p. 20), my translation AH (Archive stadsdeel Zuidoost Amstcrdam).

87. Letter from Working group Housing and Living Environment (Mart van de Wiel) to Commission Renewal Bijlmermeer district Sout-East and Commission Housing city of Amsterdam. 19-9-1993, my translation AH (Personal archive G. Munnik Amsterdam).

88. Notition Operational staff renewal Bijlmermeer, 23-9-1993 (Archive Projectbureau Vernieuwing Bijlmermeer Amsterdam).

89. Interview J. Brewster, traffic engineer, neighborhood South-East; Amsterdam: 22-71999.

90. Interview S. van der Hilst, project manager Ganzenhoef; Amsterdam: 14-7-1999.

91. Interview Brewster. Interview van Herwaarden.

92. Interview Fricling. Interview Mulder.

93. Interview Frieling. Sec also the memo by the Steering Committee: "Vernieuwing Bijlmermeer, een vitale operatie." Amsterdam: Stuurgroep Vernieuwing Bijlmermeer, 1991 (Personal archive T. van den Klinkenberg, Amsterdam).

94. It should be noted, however, that, although the problems had been defined broader, the solutions were eventually mainly limited to technical interventions. According to Martin Mulder, the social component of the renewal process was given much less attention than the physical/spatial component (Interview Mulder). Frieling however emphasized that although the Steering Committee put much energy in the social renewal, local institutions and authorities obstructed its effort. According to Frieling the early efforts of the Steering Committee were more directed at providing jobs for the Bijlmer residents than at spatial interventions (Interview Fricling).

95. Interview N. Pattiwael, director of the Project Office Renewal of the Bijlmermeer (1997-1998); Amsterdam: 4-6-1998. Interview A. Bhalotra, Kuiper Compagnons, supervisor of the structure plan Bijlmermeer; Rotterdam: 18-8-1998. Interview Lambert. On the one hand, the Bijlmer population is characterized as "homogeneous, poor and 
black". On the other hand, its diversity is always emphasized when politicians use the metaphor of the multicultural society to point at the positive aspects of the Bijlmer.

96. Werkgroep Wonen en Woonomgeving Bijlmermeer. "Ganzenhoef-west: Geen vernicling. maar vernicuwing." Reportno. 30. Amsterdam: Wijkopbouworgaan Bijlmermeer, 1992. (p. 6). my translation AH (Archive stadsdecl Zuidoost Amsterdam).

97. Werkgroep Wonen en Woonomgeving Bijlmermeer. "Ganzenhoef-west: Geen vernicling, malar vernieuwing." Reportno. 30. Amsterdam: Wijkopbouworgaan Bijlmermeer, 1992 (Archive stadsdecl Zuidoost Amsterdam).

98. Werkgroep Wonen \& Woonomgeving. "Voorwalarts en niet vergeten. Over de tockomst van de Bijlmermeer." Amsterdam: SWOB, 1991. (p. 14), my translation AH (Personal archive T, van den Klinkenberg Amsterdam).

99. See the report by the Working Group Housing and Living Environment: Werkgroep Wonen \& Woonomgeving. "Voorwalarts en niet vergeten. Over de toekomst van de Bijlmermeer." Amsterdam: SWOB, 1991 (Personal archive T. van den Klinkenberg, Amsterdam).

100. Interview Mulder.

101. See a concept report by the Project Office Renewal Bijlmermeer: "Vernieuwen na de ramp." Reportno. 9. Amsterdam: Projectburo Vernicuwing Bijlmermeer, 1992 (Archive Projectbureau Vernieuwing Bijlmermeer Amsterdam).

102. Letter Working Group Housing and Living Environment in the local newspaper "De Nieuwe Bijlmer" (1992, my translation AH). See also the letter by Hennie Bos, chair of the Independent Residents Organisation (Bos. 1992).

103. See the interview with community worker Toon Borst in the local newspaper "De Nicuwe Bijlmer" (Anonymous, 1992).

104. Interview Mulder. Sec report: "Vernieuwen na de ramp." Reportno. 9. Amsterdam: Projectburo Vernicuwing Bijlmermeer, 1992 (Archive Projectbureau Vernieuwing Bijlmermeer Amsterdam). See also Minutes Operational Staff Renewal Bijlmermeer, 911-1992 (Archive Projectbureau Vernicuwing Bijlmermeer Amsterdam).

105. Interview Lambert. For a recent, fairly enthusiastic, analysis of Lambert's plan for the Bijlmermeer, see Stuurgroep Experimenten Volkhuisvesting (2000).

106. Interview Lambert.

107. See Van Giersbergen (1997b: 33 op. cit.).

108. Interview Lambert.

109. See e.g. the advisory report by the Amsterdam Council for Town Planning (ARS, 1992) and the proposal to the city council of Amsterdam. 26-10-1990. No. 891. "De tockomst van de Bijlmermeer." (Personal archive T. van den Klinkenberg Amsterdam).

110. See Westrik (1997: 54). 
111. See Kloos (1997: 22, op. cit.).

112. Interview Roovers, my translation $\mathrm{AH}$.

113. Interview Pattiwael. Explaining the difficulty to change the Bijlmer by pointing at the existence of diverging viewpoints is more in line with my second conception of obduracy that stresses the role of (opposite) dominant ways of thinking (see Chapter 3 ).

114. Interview Frieling.

115. Interview Janssen.

116. Interview Lambert.

117. See the structural plan, supervised by Ashok Bhalotra: "De Bijlmer is mijn stad. Visie voor de ruimtelijke vernieuwing van de Bijlmermeer." Rotterdam/Arnhem: Kuiper Compagnons. Bureau voor Ruimtelijke Ordening en Architectuur B.V.. 1996 (Obtained via Kuiper Compagnons).

118. See Van Giersbergen (1997a: 44, op. cit.).

119. Interview Bhalotra.

120. Interview Bhalotra.

121. Interview Bhalotra.

122. Interview Bhalotra.

123. See De Wagt (1996).

124. According to George Munnik, the name Bijlmer Museum was suggested by Pi de Bruijn to Paul Bos, a project manager in the $\mathrm{G} / \mathrm{K}$-area, who accused these people of trying to make the Bijlmer a museum. Although negatively intended, the group adopted this name because it nicely captured their aim of preserving the Bijlmer. Between 1992 and 1994, there was a Working Group Bijlmer Muscum. This Working Group became a Foundation in order to be able to act as a legal entity. Interview G. Munnik, secretary of the Bijlmer Muscum Foundation; Amsterdam: 26-8-1998.

125. The G/K-area consists of a part of focus area Ganzenhoef and a part of focus area Kraaiennest.

126. Namely the following apartment buildings: Gooioord, Groeneveen, Grubbehoeve, Grunder, Kikkenstein, Kruitberg, Kleiburg and Koningshoef.

127. Interview Janssen.

128. See the articles of the Bijlmer Museum Foundation art. 2.2. 26-4-1994. Code: ef42730, zaaknummer: 105.857 (Personal archive G. Munnik Amsterdam).

129. See the reaction of the Bijlmer Museum Foundation to Bhalotra's first sketch: Stichting 
Bijlmermuscum. "Reactic op Bhalotra's ideeënschets Bijlmermeer." Amsterdam, 1995 (Personal archive G. Munnik Amsterdam).

130. See a brochure of the Bijlmer Museum Foundation: "Stichting Bijlmermuseum. Bewoners komen op voor de GK-buurt." Amsterdam: Stichting Bijlmermuseum, 1994 (Personal archive G. Munnik Amsterdam).

131. Interview S. Tjoa, secretary Project Offïe Renewal Bijlmermeer (1994-1997), director MP-burcalu (Multiculturalisation and Participation) (since 1998). Amsterdam: 17-111998.

132. See brochure "'Zwart-Wit' nader beschouwd. Een aanzet tot multiculturalisatie en aandeelhouderschap van de Bijlmer." Reportno. 21. Amsterdam: Zwart Beraad en Allochtonen Breed Overleg, 1997. (p. 3), my translation AH (Personal archive S. Tjoa Amsterdam).

133. The MP office (Multiculturalization and Participation) was established to support and monitor projects that aim at this. See brochure Black Council: "'Zwart-Wit' nader beschouwd. Een aanzet tot multiculturalisatie en aandeelhouderschap van de Bijlmer." Reportno. 21. Amsterdam: Zwart Beraad en Allochtonen Breed Overleg, 1997 (Personal archive S. Tjoa Amsterdam).

134. See articles of the Bijlmer Museum Foundation: art. $2 a+b$ (Personal archive G. Munnik Amsterdam).

135. See the report of a conference on the Bijlmer Muscum: "Rapportage mini-conferentic Bijlmermuseum." Amsterdam: Gemeente Amsterdam Project Management Bureau. 1998 (Personal archive B. Lavell Amsterdam). Interview van Herwaarden.

136. See a brochure of the Bijlmer Muscum Foundation: "GK-buurt: Stedelijkheid en Natuur. Bijdrage aan brainstormsessies Projectgroepen Vernieuwing over "Bijlmermuseum. problemen oplossen binnen de oorspronkelijke ontwerpuitgangspunten"." Amsterdam: Stichting Bijlmermuseum, 1996, p. 2. (Personal archive G. Munnik Amsterdam).

137. See a brochure of the Bijlmer Muscum Foundation: "Stichting Bijlmermuscum. Bewoners komen op voor de GK-buurt." Amsterdam: Stichting Bijlmermuseum. 1994 (Personal archive G. Munnik Amsterdam).

138. Sce the articles of the Bijlmer Museum Foundation: art. 2.e. (Personal archive G. Munnik Amsterdam).

139. Sec the articles of the Bijlmer Museum Foundation: art. 2.g. (Personal archive G. Munnik Amsterdam).

140. Interview Munnik.

141. Interview Munnik. Interview Lavell.

142. See "Plan van aanpak herontwikkeling Groeneveen e.o.", Projectgroep Ganzenhoef, 287-1994, (p.3). My translation AH (Archive Projectbureau Vernieuwing Bijlmermeer). 
143. Interview B. Lavell, (vice-)project manager Kraaiennest (since 1995); Amsterdam: 17 $11-1998$.

144. Interview Munnik.

145. See proposal to the district council South-East: "Voordracht inzake plan van aanpak vernieuwing K-buurt." 17-12-1996. No. 38 (Personal archive B. Lavell Amsterdam).

146. My translation AH, italies in original. Sce brochure of the Bijlmer Muscum Foundation. "GK-buurt: Stedelijkheid en Natuur. Bijdrage aan brainstormsessies Projectgroepen Vernieuwing over "Bijlmermuscum, problemen oplossen binnen de oorspronkelijke ontwerpuitgangspunten"." Amsterdam: Stichting Bijlmermuseum, 1996. "Naschrift par. 1: Parkeren” (Personal archive G. Munnik Amsterdam).

147. See brochure "GK-buurt: Stedelijkheid en Natuur. Bijdrage aan brainstormsessies Projectgroepen Vernicuwing over "Bijlmermuseum, problemen oplossen binnen de oorspronkelijke ontwerpuitgangspunten"." Amsterdam: Stichting Bijlmermuseum, 1996. "Naschrift par. I: Parkeren" (Personal archive G. Munnik Amsterdam).

148. Interview van der Hilst. Interview Munnik.

149. The term "Bijlmer believer" is commonly used in the press and in the discussions about the renewal of the Bijlmermeer to indicate those people who keep 'loving' the Bijlmer. Although this term has no negative meaning for me, the people who feel addressed by this term do not like it because in their view it has a pejorative connotation.

150. I will return to such strategies to preserve obduracy in Chapter 6.

\section{Notes to Chapter 6}

1. See the article by Bos. Mik \& Versnel (1979).

2. By December 2000 , it is still uncertain whether a tunnel will actually be built in Maastricht.

3. See Williams (1990: 206).

4. Ironically, Bijlmer residents had already shown that physical determinism does not 'work': their local practices were often in radical opposition with the intentions of the designers of the Bijlmer.

5. See Neville-Sington \& Sington (1993: 37).

6. Of course, actors may use more than one unbuilding strategy. Bakker combined the strategy of establishing historical continuity and the strategy of combining design and process interventions.

7. In this study, the InfraLab procedure is an example of such a participation model. Other recent examples are: "Forum Amsterdam", "Het kan verke(e)ren" Groningen, "Dordt spreekt" in Dordrecht, and so forth. 
8. See Brand (1994).

9. See Rossi (1982: 139).

10. See Rossi (1982: 55).

11. See Brand (1994: 11 ).

12. See MacKenzic \& Wajcman (1999a: 18).

13. The idea that artifacts can be obdurate and flexible at the same time is expressed in the concept of "boundary object". See Star \& Griesemer (1989).

14. A similar argument is made by Rip \& Kemp (1998).

15. Sec Aibar \& Bijker (1997).

\section{Notes to Epilogue}

1. See Anonymous (2000a).

2. However, Yap (2000) doubts whether budgetary problems are the only explanation for the ending of the cooperation between the partners. He suggests that lack of "confidence in the future" is the main cause for the foundering of the UCP in this stage.

3. See press release 7-3-2000: "Gemeente en NS Vastgoed onderzoeken nieuwe organisatie voor UCP. Samenwerkingsovereenkomst UCP ontbonden." And press release 24-5-2000: "Voortgang UCP: simpeler, flexibeler en in delen. B\&W van Utrecht en NS Vastgoed eens over investeringen in UCP". http:/www.utrecht-ucp.nl (last visited May 2001).

4. See press release 30-6-2000: "Raad stemt in met investeringsprogramma Utrecht Centrum Project". http://www.utrecht-ucp.n! (last visited May 2001).

5. See Anonymous (2000b).

6. Letter P. Slangen to Dagblad de Limburger, Dagblad de Limburger, 24-12-1999.

7. See Evers (1999).

8. See Groen (1999).

9. See Hulsman (1999).

10. See Parool 16-11-1999, "Meer sloop in Bijlmer" http://www.parool.nl/actucel/lunchnieuws/335(21773.html (last visited May 2001). 


\section{Bibliography}

\section{Interviews}

\section{Chapter 3}

- H. Bakker, town planning supervisor UCP (since 1996); Eindhoven: 14-8-1998.

- A. Bley, WPM Beheer Midden-Nederland; Utrecht: 6-6-1997.

- E. Bolt, manager ABP, later also employed by WBN; Heerlen: 9-7-1997.

- E. Brandes, planner, city of Utrecht; Utrecht: 8-7-1997.

- M. Dendermonde, author of a novel about the history of Hoog Catharijne and of memorial books about Bredero; Maastricht: 10-12-1997.

- A. Feddes, chairman of the Empeo-team that designed plan Hoog Catharijne; Bunnik: 19-6-1997.

- G. Groener, WBN; Utrecht: 30-6-1997.

- H. van Herwaarden, NS Vastgoed; Utrecht: 1-7-1997.

- A. Hordijk, municipal project manager UCP, initiator of the UCP Atelier: 18-111997 (Interview by phone).

- H. Kernkamp, city board member UCP (liberal-democrat party D'66) (1994-1998); Utrecht: 8-7-1997.

- C. Koemans, architect; Utrecht: 8-7-1997.

- L. Lambo, secretary BOCP, former coordinator BOCP; Utrecht: 29-4-1997.

- A. Lambooij, advisor Riek Bakker; Eindhoven: 26-2-1998.

- G. Mik, city board member UCP (socialist party PvdA) (1990-1994); Utrecht: 196-1997.

- P. Nyst, Royal Dutch Jaarbeurs; Utrecht: 1-7-1997.

- J. Peters. consultant Twijnstra Gudde; Utrecht: 12-6-1997.

- D. Regenboog, employee Bredero (1969-1976), ABP manager, external project manager UCP Kolpron Consultants (1991-1993); Rotterdam: 29-9-1997.

- A. Smits, city project manager UCP; Utrecht: 12-6-1997.

- H.S. Yap, town planning advisor UCP (1989-1995); Den Haag: 28-9-1997.

\section{Chapter 4}

- A. Cremers, city board member traffic and town planning (D'66), city of Maastricht (1990-1998); Beck: 14-9-1999.

- R. Daniels, town planner Buro 5; Maastricht: 21-4-1999. 
- F. Hendrikx. Rijkswaterstaat Limburg, project manager A2; Maastricht: 24-2-1999.

- J. Jamin, Rijkswaterstaat Limburg, highway engineer, involved in the A2 (re-) design process since the late 1950s; Maastricht: 2-2-1999.

- P. Jansen, city of Maastricht, traffic engineer; Maastricht: 4-3-1999.

- T. Jenniskens, city of Malastricht, expert on Maastricht's history and culture; Maastricht: 15-4-1999.

- O. de Jong, city of Maastricht, Department of Town Development, city coordinator of the A2-project; Maastricht: 7-5-1998.

- O. Kars, resident of one of the flats near the city passage, member of the Interest Group City Passage; Maastricht: 15-7-1999.

- C. Konsten, former A2 senior project engineer and chair Design Workplace, Bouwdienst Rijkswaterstaat; Utrecht: 20-4-1999.

- J. Kroon, Bouwdienst Rijkswaterstaat, highway engineer involved in Trajectory/EIS study; Apeldoorn: 18-8-1999.

- H. Luijpers, Province of Limburg, member of Working Group for Temporary Measures; Maastricht: 6-4-1999.

- A. Lutters, city manager between 1977 and 1998; Maastricht: 21-7-1999.

- J. Magnée, ANWB (General Dutch Automobile Association); Deurne: 11-11-1999.

- J. Nakken, Zandvoort Ordening \& Advies, chairman Design Workplace; Maastricht: 28-10-1999.

- E. Schreuders, Chamber of Commerce Maastricht; Maastricht: 19-4-1999.

- J. Smeekes, advisor innovation trajectories, inventor of the Infralab procedure; Leidschendam: 6-7-1995.

- A. Vesseur, secretary "No East Variant for the A2"; Maastricht: 16-4-1999.

\section{Chapter 5}

- A. Bhalotra, supervisor of the structure plan Bijlmermeer; Rotterdam: 18-8-1998.

- J. Brewster, traffic engineer, neighborhood South-East; Amsterdam: 22-7-1999.

- P. de Bruijn, architect, employee of the municipal Housing Department (19701977), chairman of the Bijlmermeer Management Group (1974-1977); Amsterdam: 26-8-1998.

- D. Frieling, chairman of the Renewal Bijlmermeer Steering Committee (19901992), Bijlmer resident, assistant director of the Amsterdam Public Housing Department (1967-1972); Delft: 18-8-1998.

- R. Grotendorst, former employee of the Amsterdam Federation of housing corporations (1980-1984), former (assistant) director of housing corporation Nieuw Amsterdam (1984-1989 and 1989-1996); Amsterdam: 10-8-1998.

- L. van Herwaarden, landscape architect, Neighborhood South-East; Amsterdam: 22-7-1999.

- S. van der Hilst, project manager Ganzenhoef, former Bijlmer resident; Amsterdam: 14-7-1999.

- R. Janssen, former chairman of the neighborhood council, board member neighborhood South-East (PvdA), Bijlmer resident; Amsterdam: 31-7-1998. 
- T. van den Klinkenberg, member of the Renewal Bijlmermeer Steering Committee (1990-1992); Amsterdam: 25-5-1998.

- D. Lambert, town planning supervisor Ganzenhoef; Rotterdam: 27-7-1998.

- B. Lavell, (vice-)project manager Kraaiennest (since 1995); Amsterdam: 17-111998.

- M. Mulder, Director of Project Office Renewal Bijlmermeer (1992-1996); Almere: 10-8-1998.

- G. Munnik, secretary of the Bijlmermuseum Foundation, Bijlmer resident; Amsterdam: 26-8-1998.

- N. Pattiwael, director of the Project Office Renewal of the Bijlmermeer (19971998); Amsterdam: 4-6-1998.

- I. Roovers, project manager Ganzenhoef (1993-1997); Almere: 25-5-1998.

- S. Tjoa, secretary Project Office Renewal Bijlmermeer (1994-1997), director MPbureau (Multiculturalisation and Participation) (since 1998), Amsterdam: 17-111998.

\section{Archives}

\section{Chapter 3}

- Archive Stadsbalie Utrecht

- Archive NS Vastgoed Utrecht

- Personal archive L. Lambo Utrecht

- Personal archive G. Groener Utrecht

- Personal archive C. Koemans Utrecht

- City archive Utrecht

\section{Chapter 4}

- City archive Maastricht

- Archive Stadsontwikkeling en Grondzaken (SOG) Maastricht

- Archive Rijkswaterstaat Directie Limburg, Afdeling Integraal Verkeer en Vervoer Maastricht

- Archive Bouwdienst Rijkswaterstaat Utrecht

- Archive Sociaal Historisch Centrum (SHC) Maastricht

- Personal archive O. de Jong Maastricht

- Personal archive J. Nakken Utrecht

- Personal archive J. Jamin Maastricht 


\section{Chapter 5}

- Archive Stadsdeel Zuidoost Amsterdam

- Archive Projectbureau Vernieuwing Bijlmermeer

- Personal archive T. van den Klinkenberg Amsterdam

- Personal archive G. Munnik Amsterdam

- Personal archive S. Tjoa Amsterdam

- Personal archive B. Lavell Amsterdam

- Archive Stedelijke Woningdienst Amsterdam

\section{References}

Aarden, M. (1997, 18 March). Bouwplaats Nederland. de Volkskrant, p. 11. Achterhuis, H. (1998). De erfenis van de utopie. Amsterdam: Ambo.

Aibar, E., \& Bijker, W. E. (1997). Constructing a City: The Cerdà Plan for the Extension of Barcelona. Science, Technology, \& Human Values, 22(1), 3-30.

Akrich, M. (1992). The De-Scription of Technical Objects. In W. E. Bijker \& J. Law (Eds.), Shaping Technology/Building Society (pp. 206-224). Cambridge, MA: The MIT Press.

Angenot, L. H. J. (1948, 16 December). Het planning-aspect. Paper presented at the "Autosnelwegen in en rond de stad" conference, Utrecht.

Anonymous. (1973a, 22 September). Hoog Catharijne (2). Uniek object. Utrechts Nieuwsblad.

Anonymous. (1973b, 25 September). PvdA wijst procedure Hoog-Catharijne af. de Volkskrant.

Anonymous. (1977a, 8 April). Demonstranten schrijven aan raadsleden. De Limburger, p. 7.

Anonymous. (1977b, 7 April). Moeders eisen voor kleuters veilige oversteek. De Limburger, p. 3.

Anonymous. (1978, September). De Architecten: Angst voor 7 miljoen 'stedebouwkundigen' makkt tweede Hoog-Catharijne onmogelijk. Utrechts Nieunsblad, p. 3-8.

Anonymous. (1983, l February). Omwonenden A2/E9 trekken aan de bel. Stadstraverse wordt dodenweg. De Limburger.

Anonymous. (1989, 9 May). Argwaan bij insprekers tegenover plannenmakers van City Projekt. Utrechts Nieuwsblad, p. 17.

Anonymous. (1991, 17 January). ABP wenst geen grote doorbraak in HC. Utrechts Nielusisblad. p. 13.

Anonymous. (1992, 5 November). Ontroering en schaamte bij Bijlmerramp. De Nienwe Bijlmer.

Anonymous. (2000a, 8 March). Stranden van Utrechts project wekt verbijstering. de Volkskrant, p. 3.

Anonymous. (2000b, 23 December). Verbouwing van centrum Utrecht onderworpen aan volkspeiling. de Volkskramt, p. 7. 
ARS. (1992). Over de scenario's roor de Bijlmermeer (advisory report adviesnr. 146 , nr. 7). Amsterdam: Amsterdamse Raad voor de Stadsontwikkeling.

Arthur, W. B. (1999 (1984)). Competing Technologies and Economic Prediction. In D. Mackenzie \& J. Wajcman (Eds.), The Social Shaping of Technology (second ed., pp. 106-112). Buckingham: Open University Press.

Bakker, R. (1998). Oration, Technische Universiteit Eindhoven, Eindhoven.

Berggren. H. (1956). Maastricht in 1956. Maastricht: N.V. Leiter-Nypels.

Bertolini, L., \& Spit, T. (1998). Cities on Rails. The Redevelopment of Railway Station Areas. London/New York: E \& FN Spon.

Bijker, W. E. (1987). The Social Construction of Bakelite: Toward a Theory of Invention. In W. E. Bijker, T. P. Hughes, \& T. J. Pinch (Eds.), The Social Construction of Technological Systems. New Directions in the Sociology and History of Technology (pp. 159-187). Cambridge, MA: The MIT Press.

Bijker, W. E. (1995a). Democratisering van de Technologische Culturu. Oration, Rijksuniversiteil Limburg, Maastricht.

Bijker, W. E. (1995b). Of Bicycles, Bakelites and Bulbs. Toward a Theory of Sociotechnical Change. Cambridge, MA: The MIT Press.

Bijker, W. E. (1995c). Sociohistorical Technology Studies. In S. Jasanoff, M. G. E., J. C. Petersen, \& T. Pinch (Eds.), Handbook of Science and Technology Studies (pp. 229-256). Thousand Oaks/London/New Delhi: Sage Publications.

Bijker, W. E., \& Law, J. (Eds.). (1992). Shaping Technology/Building Society. Cambridge, MA: The MIT Press.

Bijker, W. E., Hughes, T. P., \& Pinch, T. (Eds.). (1987). The Social Construction of Technological Systems. New Directions in the Sociology and History of Technology. Cambridge, MA: The MIT Press.

Birch, E. L. (1982). Urban Planning and Technological Development. Responses to the Modern City, 1909-1945. In G. H. Daniels \& M. H. Rose (Eds.), Energy and Transport. Historical Perspectives on Policy Issues (pp. 179-200). Beverly Hills/London/New Delhi: Sage Publications.

Bisscheroux, N., \& Minis, S. (1997). Architectumrgids Macistricht 1895-1995. Maastricht: Stichting Topos, Dienst SOG Gemeente Maastricht.

Blijstra, R. (1969). 2000 jaar Utrecht: stedebouwkundige ontwikkeling van castrum tot centrum. Utrecht: Bruna.

Blokker, B. (1997, 28 June). De kruimelstad. De openbare ruimte in de stad wordt steeds minder openbaar. NRC Handelsblad, p. 3.

Boer, N. d., \& Lambert. D. (1987). Woonwijken. Nederlandse stedebouw 1945-1985. Rotterdam: Uitgeverij 010.

Boesenkool, J., Cornelissen, P., Huitink, H., \& Stoffels, P. (1983). Gewoon Utrecht, en hoe woont dat? 1945-1980: van provinciestad tot betondorp. Utrecht: Huisdrukkerij RUU de Uithof.

Bolte, W., \& Meijer, J. (1981). Van Berlage tot Bijlmer. Architektunt en stedelijke politick. Nijmegen: SUN.

Boomkens, R. (1998). Een drempelwereld. Moderne ervaring en stedelijke openbacarheid. Rotterdam: NAi Uitgevers.

Bos, H. (1992, 19 November). Vernieuwing in nieuw licht. De Nielwe Bijlmer.

Bos, K.. Mik, G., \& Versnel, H. (1979). Utrecht heeft weinig geleerd van vijf jaar 
Hoog Catharijne. Wonen-TA/BK(7), 12-22.

Bost, W. (1983). Macastricht 1983. Maastricht: Leiter-Nypels B.V.

Brakenhoff, A., Dignum, K., Wagenaar, M.. \& Westzaan, M. (1991). Hoge bouw, lage status. Overheidsinvloed en bevolkingsdynamiek in de Bijlmermeer. Amsterdam: Instituut voor Sociale Geografie.

Brand, S. (1994). How Buildings Leam. What Happens After They're Built. Harmondsworth: Penguin Books Lid.

Bruijnzeels, K. V. H. (1960). Matastricht in 1960. Maastricht: N.V. Leiter-Nypels.

Brusse, P. (1997, 18 January). Chaos achter de zeewering. de Volkskrant, p. 3.

Buiter, H. (1993). Hoog Catharijne. De wording van het winkelhart van Nederland. (Vol. 18). Utrecht: Matrijs.

Burby, R. J., \& Kaiser, E. J. (1988). How Can We Assess the Content of Urban Research? Urban Affairs Quarterly, 24(1), 33-38.

Burgess, P. (1996). Should Planning History Hit the Road? An Examination of the State of Planning History in the United States. Planning Perspectives, 11, 201224.

Callon, M. (1986a). The Sociology of an actornetwork: the Case of the Electric Vehicle. In M. Callon, J. Law, \& A. Rip (Eds.), Mapping the Dynamics of Science and Technology (pp. 19-34). London: MacMillan.

Callon, M. (1986b). Some Elements of a Sociology of Translation: Domestication of the Scallops and the Fishermen of St Brieuc Bay. In J. Law (Ed.), Power, Action and Belief. A New Sociology of Knowledge? (pp. 196-233). London/Boston/Henley: Routledge \& Kegan Paul.

Callon, M. (1987). Society in the Making: The Study of Technology as a Tool for Sociological Analysis. In W. E. Bijker, T. P. Hughes, \& T. J. Pinch (Eds.), The Social Construction of Techological Systems. New Directions in the Sociology and History of Technology (pp. 83-103). Cambridge, MA: The MIT Press.

Callon, M. (1991). Techno-economic Networks and Irreversibility. In J. Law (Ed.), A Sociology of Monsters. Essays on Power, Technology and Domination (pp. 132161). New York/London: Routledge.

Callon, M. (1995). Technological Conception and Adoption Network: Lessons for the CTA Practitioner. In A. Rip, T. J. Misa, \& J. Schot (Eds.), Managing Technology in Society. The Approach of Constructive Technology Assessment (pp. 307-330). London/New York: Pinter Publishers.

Cammen, H. van der, \& Klerk, L. A. de, (1993). Ruimtelijke ordening. De ontwikkelingsgang van de ruimtelijke ordening in Nederland. Utrecht: Uitgeverij Het Spectrum B.V.

Clark, K. B. (1985). The Interaction of Design Hierarchies and Market Concepts in Technological Evolution. Research Policy (14), 235-251.

Collingridge, D. (1980). The Social Control of Technology. London: Frances Pinter.

Crimson. (1997). Re-Urb. Nieuwe plannen voor oude steden. Rotterdam: Uitgeverij 010.

Damoiseaux, R. (1981). Maastricht 1981. Maastricht: Leiter-Nypels B.V.

Das, R., Leeflang, S. A., \& Rothuizen, W. L. B. J. (1966). Op zoek naar leefruimte. Nederland met zijn bevolkingsgroei kan best bewoonbaar blijven dankzij nieuwe technieken. Amersfoort: Roelofs van Goor. 
de Volkskrant. (1997). VOL. Het debat over de nimtelijke inrichting van Nederland. Zaandam: Huig Printing BV.

Deelstra, T., Toorn, J. van, \& Bremer, J. (Eds.). (1972). De straat, vorm van samenleven. Eindhoven: Stedelijk van Abbemuseum.

Dettingmeijer, R. (1988). Van Fockema Andreae tot renovatie van HC. In K. Jacobs \& L. Smit (Eds.), De ideale stad. Ideaalplamen voor de stad Utrecht, 1664-1988 (pp. 76-114). Utrecht: Centraal Museum Utrecht.

Dibbits, H. A. M. C. (1965). De ontwikkeling van het verkeer als factor in de ruimtelijke ontwikkeling van ons land. Wetenschap en samenleving: maandblad gewijd aan de ontwikkeling der wetenschap en hatr betekenis voor mens en maatschappij, 19 (June/July), 77-87.

Dijkhuis, J. H., Ferf-van den Broeke, I. M. C., Maesen, L. J. G. van der, Melger, R., \& Klaren, M. (1975). Collectieve mimten Bijlmermeer. Analyse van een verschijnsel. Amsterdam: Gemeentelijke Dienst Volkshuisvesting.

Dosi, G. (1982). Technological Paradigms and Technological Trajectories. A Suggested Interpretation of the Determinants and Directions of Technical Change. Research Policy, 1/, 147-162.

Douma, C. (1998). Stationsarchitectumr in Nederland 1938-1998. Zutphen: Walburg Pers.

Ellis, C. (1996). Professional Conflict over Urban Form: The Case of Urban Freeways, 1930 to 1970. In M. C. Sies \& C. Silver (Eds.), Planning the Twentieth-Century American City (pp. 262-279). Baltimore/London: The Johns Hopkins University Press.

Esschoten, P. van, \& Kragten, R. (1987a, 17 January). "Openbare weg lijkt hier op de binnenkant van een warenhuis". Utrechts Nieuwsblad.

Esschoten, P. van, \& Kragten, R. (1987b, 8 January). Utrecht wil aansluiten bij plannen NS en Jaarbeurs. Utrechts Nieuwsblad.

Essers, B. (1969). Maastricht in 1969. Maastricht: Leiter-Nypels.

Evers, M. (1999, 18 December). Ineens is de file op de A2 verdwenen. Dagblad De Limburger.

Frisbie, W. P., \& Kasarda, J. D. (1988). Spatial Processes. In N. J. Smelser (Ed.), Handbook of Sociology (pp. 629-666). London: SAGE Publications.

Geus, M. de (1996). Ecologische utopiënn. Ecotopia's en het miliendebat. Utrecht: Uitgeverij Jan van Arkel.

Giersbergen, M. van (1997a). Goodbye to Utopia. Archis, 43-45.

Giersbergen, M. van (1997b). Green strips, white strips. Archis, 3, 32-35.

Giersbergen, M. van (1997c ). Working on the Infrastructure. Archis, 3, 26-28.

Gorman, M. E., \& Carlson, W. B. (1990). Interpreting Invention as a Cognitive Process: The Case of Alexander Graham Bell, Thomas Edison and the Telephone. Science, Technology, \& Human Values, 15(2), 131-164.

Graham, S., \& Marvin, S. (1996). Telecommunications and the City. Electronic Spaces, Urban Places. London/New York: Routledge.

Groen, J. (1999, 21 December). Het is lastig lobbyen met een lege snelweg. Dagblad de Limburger.

Gullberg, A.. \& Kaijser, A. (1998, 23-25 April). City Building Regimes in Post-war Stockholm. Paper presented at the "Technological Futures-Urban Futures" 
conference, Durham.

Guy, S., Graham, S., \& Marvin, S. (1997). Splintering Networks: Cities and Technical Networks in 1990s Britain. Urban Studies, 34(2), 191-216.

Haagsma, I. (1976, 7 August). Hoog Catharijne: een grote couveuse. NRC Handelsblad, p. 3.

Hajer, M., \& Halsema, F. (Eds.). (1997). Land in zicht! Een cultunrpolitieke visie op de ruimtelijke inriching. Amsterdam: Wiardi Beckman Stichting/Uitgeverij Bert Bakker.

Hall, P. (1988). Cities of Tomorrow: an Intellectual History of Urban Plaming and Design in the 20th Century. Oxford: Blackwell Publishers.

Hanner, U. (1980). Exploring the City. Inquiries Toward an Urban Anthropology. New York: Columbia University Press.

Hendriks, E., \& Nijland, R. (1996, 21 December). De verticale vooruitgang. de Volkskrant, p. 13.

Hofland, H. J. A. (1996, 23 November). Markermeer of Markerwaard. De radicale herbouw van Nederlands is al lang in volle gang. NRC Handelsblad, p. 5.

Hommels, A. M. (1995). De rol van expertise bij bes/uitvorming over problemen rond techniekontwikkeling. Hoe worden burgers en technici "co-makers" van een weg? MA-thesis, Universiteit Maastricht, Maastricht.

Hommels, A. M. (1997). Praatgroep voor N44. Omwonenden, weggebruikers, belangengroepen en technici betrokken bij problematiek drukke weg. De Ingenieur, l09(4), 17-19.

Hommels, A. M. (2000). Obduracy and Urban Sociotechnical Change. Changing Plan Hoog Catharijne. Urban Affairs Review, 35(5), 649-676.

Horst, J. ter, Meyer, H., \& Vries, A. de (1991). Sleutelen aan de Bijlmer. Interpretaties. Delft: Faculteit der Bouwkunde.

Hughes, T. P. (1983). Networks of Power. Electrification in Western Society, 18801930. Baltimore/London: The John Hopkins University Press.

Hughes, T. P. (1987). The Evolution of Large Technological Systems. In W. E. Bijker, T. Hughes, P., \& T. J. Pinch (Eds.), The Social Construction of Technological Systems (pp. 51-82). Cambridge, MA: The MIT Press.

Hughes, T. P. (1988). The Seamless Web: Technology, Science, et cetera, et cetera. In B. Elliott (Ed.), Technology and Social Process (pp. 9-19). Edinburgh: Edinburgh University Press.

Hughes, T. P. (1994). Technological Momentum. In M. R. Smith \& L. Marx (Eds.), Does Technology Drive History? The Dilemma of Technological Determinism (2nd ed., pp. 101-113). Cambridge, MA: The MIT Press.

Hughes, T. P. (1998). Rescuing Prometheus. New York: Pantheon Books.

Hughes, T. P., \& Hughes, A.. C. (1990). Lewis Mumford. Public Intellectual. New York/Oxford: Oxford University Press.

Huisman, J. (1998, 3 January). De zwarte jaren zestig. de Volkskrant, p. 13.

Huisman, J. (1999, 11 December). Gescharrel in de ruimte. Vrij Nederland, 70-71.

Huls, B. B. J., \& Bomers, R. J. (1983). Advies inzake de Bijlmermeer. Amsterdam: Amsterdamse Raad voor de Stedebouw.

Hulsman, B. (1999, 8 December). Herzien. NRC Handelsblad, p. 26.

Jacobs, J. (1964 (1961)). The Death and Life of Great American Cities. The Failure of 
Town Planning. Harmondsworth: Penguin Books/Jonathan Cape.

Jacobs, J. M. (1993). The City Unbound: Qualitative Approaches to the City. Urban Studies, 30(4/5), 827-848.

Joerges, B. (1988). Large Technical Systems: Concepts and Issues. In R. Mayntz \& T. P. Hughes (Eds.), The Development of Large Technical Systems (pp. 9-36). Frankfurt am Main: Campus Verlag.

Joerges, B. (1999). Do Politics Have Artefacts? Social Studies of Science, 29(3), 411 431.

Johnson-McGrath, J. (1997). Who Built the Built Environment? Artifacts, Politics, and Urban Technology. Technology and Culture, 38(3), 690-696.

Jong, R. de (1972). Herovering van de straat? Sociaal-economische ontwikkeling in de negentiende en twintigste eeuw. In T. Deelstra, J. van Toorn, \& J. Bremer (Eds.), De straat, vorm van samenleven (pp. 13-22). Eindhoven: Stedelijk van Abbemuseum.

Jonge, D. de (1993). Op verkenning in de betonwoestijn. Delft: Delftse Universitaire Pers.

Kiers, A. G. (1997, 6 September). Hoog Catharijne niet oogstrelend bedoeld. de Volkskramt.

Kitt Chappell, S. A. (1989). Urban Ideals and the Design of Railroad Stations. Technology and Culture, 30, 354-375.

Kloos, M. (1997). A Perpetual Stumbling Block. Archis, 3, 22-23.

Konvitz, J. W. (1985). The Urban Millennium. The City-Building Process from the Early Middle Ages to the Present. Carbondale/Edwardsville: Southern Illinois University Press.

Konvitz, J. W., Rose, M. H., \& Tarr, J. A. (1990). Technology and the City. Technology and Culture, 3/(2), 284-294.

Koolhaas, R. (1977). Wat betreft de Bijlmer. In M. A Campo, H. de Kovel, M. Marijnissen, J. Molenaar, \& P. Sas (Eds.), Bijlmerstrip (pp. 3-5). Delft: TU Delft.

Kräwinkel, M. (1997). Nienw vogwerk voor de wijk. Een netwerkanalyse van de effecten van volkshnisvestingsregelgeving op beshitvormingsprocessen rondom wijkverbetering. PhD thesis, Universiteit Groningen, Groningen.

Kuipers, M. C. (1987). Bouwen in beton. Experimenten in de volkshuisvesting voor 1940. 's-Gravenhage: Staatsuitgeverij.

Kune, H., \& Erkel, F. van (1995). InfraLab experimenteen met interactieve plamvorming. Rijkswaterstatat leert door te doen.

La Porte, T. R. (Ed.). (1991). Social Responses to Large Technical Systems. (Vol. 58). Dordrecht/Boston/London: Kluwer Academic Publishers.

Lange, G. C. (1948, 16 December). Het stedebouwkundig aspect. Paper presented at the "Autosnelwegen in en rond de stad" conference, Utrecht.

Larson, M. S. (1993). Behind the Postmodern Facade. Architectural Change in Late Twenticth-Century America. Berkeley: University of California Press.

Latour, B. (1987). Science in Action: How to Follow Scientists and Engincers Through Society. Cambridge: Harvard University Press.

Latour, B. (1988). The Prince for Machines as well as for Machinations. In B. Elliott (Ed.), Technology and Social Process (pp. 20-43). Edinburgh: Edinburgh University Press. 
Latour, B. (1996). Aramis or the Love of Technology (Catherine Porter. Trans.). Cambridge, MA: Harvard University Press.

Law, J. (1987). Technology and Heterogeneous Engineering: The Case of Portuguese Expansion. In W. E. Bijker, T. P. Hughes, \& T. J. Pinch (Eds.), The Social Construction of Technological Systems. New Directions in the Sociology and History of Technology (pp. 111-134). Cambridge, MA: The MIT Press.

Law, J. (1991). Power, Discretion and Strategy. In J. Law (Ed.), A Sociology of Monsters. Essaws on Power, Technology and Domination (pp. 165-191). London/New York: Routledge.

Law, J., \& Mol, A. (1995). Notes on materiality and sociality. The Sociological Review, 274-294.

Lente, H. van (1993). Promising Technology. The Dynamics of Expectations in Technological Developments. PhD thesis, WMW-publikatie 17, Universiteit Twente, Enschede.

Luckin, B. (1991). Sites, Cities, and Technologies. Journal of Urban History, 17(4), 426-433.

Luijten, A. (1997). A Barrel of Contradictions. The Dynamic History of the Bijlmermeer. Archis, 3, 14-21.

Lynch, K. (1990 (1958)). Environmental adaptability. In T. Banerjee \& M. Southworth (Eds.), City Sense and City Design. Writings and Projects of Kevin Lynch (Reprinted from: Journal of the American Institute of Planners 24, no. 1, pp. 1624 ed., pp. 379-395). Cambridge, MA: The MIT Press.

MacKenzie, D. (1995). Knowing Machines. Essays on Technical Change. Cambridge, MA: The MIT Press.

MacKenzie, D., \& Wajcman, J. (Eds.). (1985). The Social Shaping of Technology. Milton Keynes: Open University Press.

MacKenzie, D., \& Wajcman, J. (1999a). Introductory Essay: the Social Shaping of Technology. In D. MacKenzie \& J. Wajcman (Eds.), The Social Shaping of Technology (pp. 3-27). Buckingham: Open University Press.

MacKenzie, D., \& Wajcman, J. (Eds.). (1999b). The Social Shaping of Technology (second ed.). Buckingham: Open University Press.

Mayntz, R., \& Hughes, T. P. (Eds.). (1988). The Development of Large Technical Systems. Frankfurt am Main: Campus Verlag.

McKay, J. P. (1988). Comparative Perspectives on Transit in Europe and the United States, 1850-1914. In J. A. Tarr \& G. Dupuy (Eds.), Technology and the Rise of the Networked City in Europe and America (pp. 3-21). Philadelphia: Temple University Press.

McShane, C. (1994). Down the Asphalt Path. The Automobile and the American City. New York: Columbia University Press.

Melger, R., Haan, J. de, Lammeren, L. van, \& Teune, W. (1987). Effectrapportage Hoogbouw Bijlmermeer. Amsterdam: Gemeentelijke Dienst Volkshuisvesting. Mentzel, M. (1989). Bijlmermeer als grensverleggend ideaal. Een studie over de Amsterdamse stadsuitbreidingen. (Vol. 21). Delft: Delftse Universitaire Pers.

Meyerson, M. (1961). Utopian Traditions and the Planning of Cities. Daedalus: Jounal of the American Academy of Arts and Sciences, 89(Winter), 180-193.

Ministerie van Verkeer en Waterstaat. (1988). Tweede Structunischema Verkeer en 
Vervoer (Deel a: beleidsvoomemen 20 922). 's-Gravenhage: Ministerie van Verkeer en Waterstaat.

Misa, T. J. (1988). How Machines Make History, and How Historians (and Others) Help Them to Do So. Science, Technology, \& Human Values, $13(3$ \& 4), 308331.

Mochring, E. P. (1982). Public Works and Urban History: Recent Trends and New Directions. Essays in Public Works History (13), 1-60.

Moehring. E. P. (1990). The Networked City. A Euro-American View. Joumal of Urban History, 17(1), 89-97.

Monkkonen, E. H. (1988). America Becomes Urban. The Development of U.S. Cities \& Towns, 1780-1980. Berkeley: University of California Press.

Mumford, L. (1961). The City in History. Its Origins, Transformations, and Its Prospects. New York: Harcourt. Brace \& World, Inc.

Mumford, L. (1966). The Myth of the Machine. Volume One: Technics and Human Development. San Diego: Harcourt Brace Jovanovich.

Mumford, L. (1968 (1956)). The Urban Prospect. New York: Harcourt, Brace \& World, Inc.

Mumford, L. (1970 (1938)). The Culture of Cities. (3rd ed.). London/New York: Harcourt Brace Jovanovich.

Mumford, L. (1973 (1965)). Utopia, The City and The Machine. In F. E. Manuel (Ed.), Utopias and Utopian Thought (First British Edition ed., pp. 3-24). London: Souvenir Press.

N.V. Maatschappij voor Projectontwikkeling 'Empeo'. (1962). Plan Hoog Catharijne. Bijdrage tot Utrechts centramfinktie. Utrecht: EMPEO.

N.V. Maatschappij voor Projectontwikkeling 'Empeo'. (1963). Hoog Catharijne, acmulling. Utrecht: EMPEO.

Nelson, R. R., \& Winter, S. G. (1977). In Search for a Useful Theory of Innovation. Research Policy(6), 36-76.

Neville-Sington, P., \& Sington, D. (1993). Paradise Dreamed. How Utopian Thinkers Have Changed the Modern World. London: Bloomsbury.

Peters, P. (1998). De smalle marges van de politiek. In H. Achterhuis \& B. Elzen (Eds.), Cultutu en Mobiliteit (pp. 39-63). Den Haag: Rathenau Instituut.

Pinch, T. (1999). The Sociology of Technology and Path Dependency: the Case of the Electronic Music Synthesizer (Unpublished paper, forthcoming).

Pinch, T. J., \& Bijker, W. E. (1984). The Social Construction of Facts and Artifacts: or How the Sociology of Science and the Sociology of Technology might Benefit Each Other. Social Studies of Science, 14(3), 399-441.

Pinch, T. J., \& Bijker, W. E. (1987). The Social Construction of Facts and Artifacts: Or How the Sociology of Science and the Sociology of Technology Might Benefit Each Other. In W. E. Bijker, T. P. Hughes, \& T. Pinch (Eds.), The Social Construction of Technological Systems. New Directions in the Sociology and History of Technology (pp. 17-50). Cambridge, MA: The MIT Press.

Pol, M., \& Nägele, R. C. (1996). Verslag Open Planproces Rijksweg 2 Passage Maastricht (TT96-31): Traffic Test bv. Instituut voor onderzoek en beleidsadvisering op gebied van verkeer en vervoer.

Provoost, M. (1996). Asfalt. Automobiliteit in de Rotterdamse stedebouw. Rotterdam: 
010 .

Rip, A., \& Kemp. R. (1998). Technological Change. In S. Rayner \& E. L. Malone (Eds.), Human Choice and Climate Change (Vol. II Resources and technology, pp. 327-399). Columbus: Batelle Press.

Rooij, A. de (1994). Het Infralab-initiatief vraagt om een vernienwde veroersplanologie (paper): Hoofddirectie Rijkswaterstaat, afdeling Innovatie \& Synthese.

Rose, M. H., \& Clark, J. G. (1979). Light, Heat, and Power. Energy Choices in Kansas City, Wichita, and Denver, 1900-1935. Journal of Urban History, 5(3), 340364.

Rosen, C. (1989). Book review of "The City and Technology". Technology and Culture, 30(4), 1070-1072.

Rosen. C. M. (1986). Infrastructural Improvement in Nineteenth-Century Cities. A Conceptual Framework and Cases. Jommal of Urban History, 12(3), 2 I 1-256.

Rossi, A. (1982). The Architecture of the City (Ghirardo, Diane Ockman, Joan, Trans.). (6th ed.). Cambridge, MA: The MIT Press.

Rouw, W. de (1970). Maastricht 1970. Maastricht: N.V. Leiter-Nypels.

Sansone, L. (1992). Schitteren in de schaduw. Overlevingsstrategieën, subcultunr en etniciteit ran Creoolse jongeren wit de lagere klasse in Amsterdam 1981-1990. Amsterdam: Het Spinhuis.

Schot, J.. Hoogma, R., \& Elzen, B. (1994). Strategies for Shifting Technological Systems. The Case of the Automobile System. Futures, 26(10), 1060-1076.

Schwarz Cowan, R. (1985). How the refrigerator got its hum. In D. Mackenzie \& J. Wajcman (Eds.), The Social Shaping of Technology. (pp. 202-218). Milton Keynes: Open University Press.

Sies, M., \& Silver, C. (1996). Introduction. The History of Planning History. In M. Sies \& C. Silver (Eds.), Planning the Twentieth-Century American City (pp. 1 34). Baltimore/London: The Johns Hopkins University Press.

Smets, A. J. H. (2000). Wervende woommilieus in de stad? Stedelijke herstructurering geëvalueerd. PhD thesis, Universiteit Utrecht, Utrecht.

Smith, M. R., \& Marx, L. (Eds.). (1995). Does Technology Drive History? The Dilemma of Technological Determinism (2nd ed.). Cambridge, MA: The MIT Press.

Spaans, M. (2000). Realisatie van stedelijke revitaliseringsprojecten. Een intemationale vergelijking. PhD thesis, Technische Universiteit Delft, Delft.

Star, S. L. (1991). Power, Technology and the Phenomenology of Conventions: On Being Allergic to Onions. In J. Law (Ed.), A Sociology of Monsters. Esways on Power, Technology and Domination (pp. 26-57). London/New York: Routledge.

Star, S. L., \& Griesemer, J. R. (1989). Institutional Ecology, 'Translations' and Boundary Objects: Amateurs and Professionals in Berkeley's Museum of Vertebrate Zoology, 1907-39. Social Studies of Science, 19, 387-420.

Staudenmaier, J. M. (1985). Technology's Storytellers. Reweaving the Human Fabric: Cambridge, MA: The Society for the History of Technology and the MIT Press. Stoppelenburg, P. (1972). Nieuwe stedebouw als maatschappelijk verschijnsel. In T. Deelstra, J. van Toorn, \& J. Bremer (Eds.), De straat, vorm van samenleven 
(pp. 142-147). Eindhoven: Stedelijk van Abbemuseum.

Stuurgroep Experimenten Volkshuisvesting. (2000). Herwonnen schoonheid. Vier voorbeeldplamen van vormgeving in naoorlogse herontwikkelingswijken. Rotterdam: Drukkerij Erasmus.

Summerton, J. (1992). District Heating Comes to Town. The Social Shaping of an Energy System. PhD thesis, Linköping University, Linköping.

Summerton, J. (Ed.). (1994a). Changing Large Technical Systems. Boulder/San Francisco/Oxford: Westview Press.

Summerton, J. (1994b). Introductory Essay: The Systems Approach to Technological Change. In J. Summerton (Ed.), Changing Large Technical Systems (pp. 1-21). Boulder/San Francisco/Oxford: Westview Press.

Sutcliffe, A. (1988). Street Transport in the Second half of the Nineteenth Century: Mechanization Delayed? In J. A. Tarr \& G. Dupuy (Eds.), Technology and the Rise of the Networked City in Europe and America (pp. 22-39). Philadelphia: Temple University Press.

Tarr, J. A. (1984). The Evolution of the Urban Infrastructure in the Nineteenth and

Twentieth Centuries. In R. Hanson (Ed.), Perspectives on Urban Infrastructure (pp. 4-66). Washington D.C.: National Academy Press.

Tarr, J. A., \& Dupuy, G. (1988a). Preface. In J. A. Tarr \& G. Dupuy (Eds.), Technology and the Rise of the Networked City in Europe and America (pp. xiii-xvii). Philadelphia: Temple University Press.

Tarr, J. A., \& Dupuy, G. (Eds.). (1988b). Technology and the Rise of the Networked City in Europe and America. Philadelphia: Temple University Press.

Tarr, J. A., \& Konvitz, J. W. (1987). Patterns in the Development of the Urban Infrastructure. In H. J. Gillette \& Z. L. Miller (Eds.), American Urbanism. A Historiographical Review (Vol. 125, pp. 195-226). New York/Westport/London: Greenwood Press.

Taverne, E. (1983). Architects without architecture. Architectuurdiscussie in Nederland 1940-1980. In U. Barbieri (Ed.), Architectutur en Planning. Nederland 1940-1980 (pp. 24-47). Rotterdam: Uitgeverij 010.

Thewissen, M. A. F. C. (1958). Maastricht in 1958. Maastricht: N.V. Leiter-Nypels.

Tod, I., \& Wheeler, M. (1979). Utopia. Weveldhervormers tussen werkelijkheid en fantasic (Tist, A.F., Trans.). Haarlem: De Haan.

Trefil, J. (1994). A Scientist in the City. New York: Doubleday.

Truffer, B., \& Dürenberger, G. (1997). Outsider Initiatives in the Reconstruction of the Car: The Case of Lightweight Vehicle Milieus in Switzerland. Science, Technology, \& Human Values, 22(2), 207-234.

Utterback, J. M., \& Suárez, F. F. (1993). Innovation, Competition, and Industry Structure. Research Policy, 22, 1-21.

Valk, W. de (1973, 14 July). De van God gegeven, in beton gegoten onwrikbaarheid van Hoog Catharijne. de Volkskrant, p. 17.

Vance, J. E. J. (1977). This Scene of Man. The Role and Structure of the City in the Geography of Western Civilization. New York/Hagerstown/San Francisco/London: Harper's College Press.

Venne, J. J. J. van de (1958). Een verkeersgeleidingsplan voor de Maastrichtse city (lecture). 
Venne. J. J. J. van de (1959). Verkeersplannen in Maastricht. Publieke Werken, 27(3), 4- 10 .

Venne, J. J. J. van de (1962). Maastricht-stad in een keurslijf. Publieke Werken(April).

Venne, J. J. J. van de (1964a). Maastricht, een visie op de toekomst. Maastricht: Gemeente Maastricht.

Venne, J. J. J. van de (1964b). Modern Town Planning in Maastricht. A History of and Introduction to the practice of town planning in Mastricht(lecture).

Verhagen, E. (1987). Van Bijlmermeerpolder tot Amsterdam Zuidoost. Den Haag: Sdu uitgeverij.

Wagt, W. de (1996, 17 July). De stedebouwer. De Groene Amsterdammer.

Werkgroep Wonen en Woonomgeving Bijlmermeer. (1992, 5 November). Maakt de ramp verschil? De Nienwe Bijlmer.

Westrik, J. (1997). Enthusiasms. New Urban Plans for the Bijlmermeer. Archis, 3, 4955.

Williams, R. (1990). Notes on the Underground: An Essay on Technology, Society, and the Imagination. Cambridge, MA: The MIT Press.

Winner, L. (1999 (1980)). Do Artifacts Have Politics? In D. MacKenzie \& J. Wajcman (Eds.). The Social Shaping of Technology (second ed., pp. 28-40). Buckingham/Philadelphia: Open University Press.

Wit, B. de (1993). Van verguisd beton naar leefbare derde-wereldstad. In $R$. Boomkens (Ed.), Ontwerpen voor de onmogelijke stad (pp. 15-25). Amsterdam: De Balie.

Woud, A. van der (1983). Het Nieuwe Bouwen. Rijksmuseum Kroller-Muller: Delft University Press.

Wyatt, S. (1998). Technology's Arrow. Developing Information Networks for Public Administration in Britain and the United States. PhD thesis, University of Maastricht, Malastricht.

Yap, H. S. (2000). De stad als uitdaging. Politiek, plamning en praktijk van de stedenbomw. Rotterdam: NAi Uitgevers.

Zukin, S. (1992). The Postmodern Invasion. International Journal of Urban and Regional Research, /6(3), 489-495.

Zundert, J. W. van (1996). Het bestemmingsplan. Een juridisch-bestuurlijke inleiding in de rummelijke ordening. (8th ed.). Alphen aan den Rijn: Samson H.D. Tjeenk Willink. 


\section{Samenvatting}

De jaren '90 in Nederland worden gekenmerkt door een explosie van nieuwe ruimtelijke plannen en bouwactiviteiten in steden. Er worden jaarlijks vele nieuwe plannen gemaakt voor de revitalisatie, reconstructie en sloop van woonwijken, binnensteden of stedelijke infrastructuur. Het is opmerkelijk dat daarbij zelfs voor relatief recente projecten die in de jaren ' 60 ) ontworpen en gebouwd zijn, al plannen bestaan voor herinrichting of sloop. Door veranderde ideeën over de rol van auto's in steden, nieuwe trends in de architectuur, of aangepast beleid worden veel grootschalige projecten uit de jaren ' 60 in de jaren ' 90 alweer bestempeld als "mislukkingen". Deze stroom aan plannen bevestigt enerzijds het idee van stedenbouw als continu proces: steden worden telkens herbouwd en zijn nooit af. Anderzijds blijkt juist dat het vaak heel moeilijk is om het ontwerp van steden aan te passen. Als stedelijke structuren eenmaal ingebed zijn is het niet altijd makkelijk om daadwerkelijk nieuwe fysieke ingrepen te realiseren. Stedenbouwkundige projecten zijn vaak onderwerp van moeizame debatten. Dit leidt tot jarenlange impasses in planprocessen, uitstel van projecten en soms zelf afstel. Deze spanning tussen pogingen om steden te veranderen en de 'hardheid' van de stedelijke artefacten en netwerken die al ingebed zijn is het centrale thema van dit proefschrift. De centrale vragen in dit proefschrift zijn: Hoe kunnen steden aangepast worden aan nieuwe ideeën en veranderd beleid? Waarom behouden sommige stedelijke structuren hun hardheid ondanks pogingen om ze te veranderen? Welke strategieën ontwikkelen actoren om te behouden wat ter discussie staat of om te veranderen wat zeer robuust lijkt?

Dit thema van hardheid ('obduracy') en verandering van sluit aan bij een belangrijk theoretisch debat in het wetenschaps- en techniekonderzoek. Als technische systemen eenmaal een plek gekregen hebben in een maatschappij en verbonden zijn geraakt met andere technologieën, menselijke gewoontes, investeringen en belangen, lijkt het vaak haast onmogelijk om ze nog te veranderen; het systeem is hard geworden en verzet zich tegen verandering. In dit proefschrift vat ik steden op als grote sociotechnische artefacten. Het stedelijk weefsel wordt in belangrijke mate gevormd door technische netwerken zoals wegen, communicatienetwerken, tunnels, bruggen, en energiesystemen. Tegelijkertijd weerspiegelt de stad de opvattingen van verschillende historische periodes en zijn er politieke denkbeelden, culturele idealen en economische keuzes 'gestold' in het ontwerp van steden. Een van de doelstellingen van dit proefschrift is te laten zien dat bepaalde concepten uit het wetenschaps- en techniekonderzoek behulpzaam kunnen zijn bij de analyse van stedelijke sociotechnische veranderingsprocessen.

In deze studie ligt de nadruk op stedelijke artefacten en structuren die onderwerp geworden zijn van discussie en pogingen tot herinrichting ('unbuilding') 
Deze concentratie op pogingen tot verandering kan inzicht verschaffen in de omstandigheden waaronder verandering uiteindelijk mogelijk wordt of achterwege blijft. Om de voortdurende spanning tussen hardheid en verandering in steden te kunnen onderzocken heb ik drie stedenbouwkundige herinrichtingsprojecten bestudeerd warin dit thema een cruciale rol speelt. Het gaat om Nederlandse projecten die rond de jaren '60 ontworpen en grotendeels gebouwd zijn en waarvan de pogingen tot herontwerp doorlopen tot ver in de jaren '90: (1) de herinrichting van het stationsgebied en winkelcentrum Hoog Catharijne in het Utrecht City Project; (2) de reconstructie van de $\mathrm{A} 2$ stadstraverse door Maastricht en (3) de ruimtelijke vernieuwing van de Bijlmermeer. Een van de doelstellingen van dit proefschrift is inzicht verwerven in de spanning tussen weerbarstigheid en verandering in deze drie grootschalige stedelijke herinrichtingsprojecten. Daarnaast heeft dit proefschrift een andere, meer theoretische doelstelling. De case studies hebben tot doel om theoretische inzichten in de hardheid van techniek te verfijnen.

Een inventarisatie en analyse van verschillende theoretische concepten van 'obduracy' komt aan de orde in hoofdstuk 2. Op basis van een analyse van historische. sociologische en economische benaderingen van techniekontwikkeling en stadsgeschiedenis, heb ik een indeling gemaakt in vier soorten concepten die dienen ter verklaring van het fenomeen hardheid van techniek: (1) materiële hardheid; (2) dominante denkramen; (3) de mate van verknooptheid van sociale en technische elementen; (4) hardnekkige tradities. Elke categorie van concepten benadrukt verschillende mechanismen in het ontstaan van hardheid. De notie van materiële hardheid is vooral te vinden in stadshistorische studies. Hierin wordt sterk benadrukt dat met name materiële factoren, bijvoorbeeld de materialen waarvan stedelijke artefacten gemaakt zijn, een belangrijke verklaring vormen voor de moeizame verandering van stedelijke structuren. Het bezwaar tegen dergelijke benaderingen is dat ze te veel, eenzijdig de nadruk leggen op materiële factoren en de neiging hebben om inflexibiliteit te zien als een intrinsieke eigenschap van stedelijke artefacten.

In tegenstelling tot de categorie materiële hardheid, benadrukken de drie andere categorieën juist dat de hardheid van techniek de uitkomst van een proces is in plaats van de oorzaak. Deze zogenaamde constructivistische benaderingen kenmerken zich door een symmetrische benadering: het is niet vooraf en onafhankelijk van de context duidelijk of sociale of technische factoren de verklaring vormen voor het ontstaan van hardheid. De eerste categorie binnen de constructivistische benaderingen is "dominante denkramen'. Deze categorie bestaat uit benaderingen die de hardheid van techniek verklaren uit het 'vast' zitten van actoren in een bepaalde manier van denken en interacteren. Deze interactionistische benaderingen benadrukken dat denkramen opgebouwd worden in de interacties tussen actoren en dat de strijd tussen groepen met tegengestelde denkramen een belangrijke rol kan spelen in het ontstaan van hardheid. Als bepaalde denkramen opgebouwd zijn rond een bepaald artefact, wordt het voor bepaalde actoren moeilijk om hieraan te ontsnappen. Vaak zijn er buitenstaanders nodig om de rigiditeit van deze denkramen te doorbreken. Concepten in deze categorie zijn bijvoorbeeld technisch raam (Bijker), wereldbeelden (Truffer \& Dürrenberger; Ellis), en mentale modellen (Gorman \& Carlson). Deze concepten zijn afkomstig uit het techniekonderzoek, maar vergelijkbare concepten worden ook gebruikt in de geschiedenis van stadsplanning. 
De derde categorie benadrukt de verknooptheid van sociale en technische elementen in een netwerk als verklaring voor de toenemende weerstand tegen verandering van zo'n netwerk. Doordat sociale en technische clementen in de loop van de tijd steeds meer met elkaar verknoopt raken, wordt het moeilijker het geheel of delen ervan te veranderen. Binnen deze categorie ligt de nadruk het vaststellen van de sterkte van de bindingen tussen de sociale en technische elementen. Hoe sterker de bindingen tussen de elementen en hoe langer het netwerk, hoe moeilijker het te veranderen is. In deze relationele benadering is hardheid het effect van de relaties tussen elementen in een netwerk. Auteurs in de traditie van de actor-netwerk theorie gebruiken deze benadering van hardheid (Latour; Callon; Law \& Mol; Akrich).

De vierde categorie ten slotte, benadrukt het bestaan van hardnekkige tradities in techniekontwikkeling. Eerdere beslissingen en keuzes blijven het "traject" van techniekontwikkeling gedurende lange tijd beïnvloeden. Economen gebruiken de metafoor van "pad-afhankelijkheid" om dit fenomeen aan te duiden (Nelson \& Winter; Dosi; Arthur). Techniekhistorici benadrukken het belang van culturele tradities en telkens terugkerende "archetypes" in techniekontwikkeling (Williams). Deze tradities en archetypes kunnen verklaren waarom bepaalde ontwerpen telkens terugkomen en hun invloed over langere tijd behouden. In tegenstelling tot de categorie dominante denkramen overstiggen de concepten in deze categorie de lokale context en spelen sociale groepen en hun onderlinge strijd een veel minder prominente rol. Concepten in deze categorie benadrukken juist het belang van collectieve tradities en waarden die over groepen heen een bredere culturele invloed hebben.

Een confrontatie tussen de bestudering van drie stedelijke herinrichtingsprojecten in Nederland en de theoretische concepten van hardheid van techniek is nodig om de conceptualisering van hardheid in de stedelijke context te kunnen verfijnen. Omdat de eerste categorie, materiële hardheid, niet past binnen de algemene constructivistische gedachtengang in dit proefschrift heb ik deze buiten beschouwing gelaten in de analyse van de case studies. Ik gebruik de drie constructivistische categorieën van concepten van hardheid om de verklaringskracht en de specificiteit ervan in de case studies te laten zien.

Het empirische deel van mijn onderzoek is gebaseerd op interviews met belangrijke actoren en bestudering van uiteenlopende schriftelijke bronnen. Ik heb twee criteria gebruikt voor de selectie van actoren: De geïnterviewden waren direct betrokken bij het herinrichtingsproces dat ik bestudeerde. Ze speelden ofwel een rol in de pogingen tot behoud van stedelijke structuren ofwel in de pogingen tot verandering ervan. Ten tweede heb ik gezorgd voor een zo goed mogelijke spreiding van actoren over verschillende fasen in het herontwerpproces. Schriftelijke bronnen waren afkomstig van uiteenlopende archieven. Omdat mijn aandacht uitging naar het proces van 'herontwerpen' in plaats van naar het ontstaan van de drie projecten, heb ik me geconcentreerd op primaire bronnen voortgekomen uit het 'unbuilding' proces. In het geval van Hoog Catharijne en het Utrecht City project betekent dit dat de nadruk ligt op de periode tussen 1986 en 1997. Bij de Maastrichtse casus is met name de fase van 1974 tot 1998 geanalyseerd. De ruimtelijke vernieuwing van de Bijlmermeer speelt zich in dezelfde periode af, met een nadruk op de periode na 1986 toen de sloopplannen definitief werden.

De analyse van deze herinrichtingsprojecten staat centraal in hoofdstuk 3, 4 en 
5. In hoofdstuk 3 beschrijf ik de pogingen tot herinrichting van het Utrechtse stationsgebied en Hoog Catharijne. Burgers van Utrecht beschouwen het ontwerp van Hoog Catharijne als achterhaald en onveilig en daklozen en verslaafden bevolken het winkelcentrum in toenemende mate. De gemeente Utrecht, het ABP (de eigenaar van Hoog Catharijne), de Jaarbeurs en de Nederlandse Spoorwegen besloten eind jaren ' 80 tot een samenwerkingsverband om het hele stationsgebied aantrekkelijker te maken. Ik gebruik het concept "technisch raam" om de interacties en onderhandelingen van verschillende groepen actoren rond het herontwerp van Hoog Catharijne te analyseren. Ik laat zien hoe door twee belangrijke groepen actoren, de Gemeente Utrecht en het $\mathrm{ABP}$ twee opponerende technische ramen opgebouwd werden die gedurende bijna tien jaar stabiel bleven. In het technisch raam van de gemeente was het verbeteren van de leefbaarheid op de begane grond erg belangrijk. De oplossingen die de gemeente formuleerde waren sterk gericht op de realisatie van deze doelstelling: bijvoorbeeld het creëren van nieuwe voetgangersroutes en winkels op straatniveau. Voor het ABP was het handhaven en verbeteren van het winkelniveau van Hoog Catharijne op 6 meter boven straatniveau van groot belang. De hoge inclusie van het $\mathrm{ABP}$ en de gemeente Utrecht in hun technische ramen resulteerde in een "opsluitende hardheid". Beide groepen waren niet meer in staat om oplossingen te bedenken voor het herontwerp van Hoog Catharijne buiten de door hen al jaren aangehangen opvattingen hierover. Deze situatie van twee tegenovergestelde denkramen zorgde voor een patstelling in het planproces. Hierdoor behield Hoog Catharijne haar hardheid. Een andere prominente groep actoren, de burgers van Utrecht, accepteerde Hoog Catharijne of formuleerde radicale voorstellen voor de herinrichting of sloop van het winkelcentrum, een voorbeeld van "weerbarstige hardheid". Een nieuw aangestelde stedenbouwkundig supervisor, Riek Bakker, speelde een belangrijke rol in de pogingen om de twee tegengestelde denkramen met elkaar te verenigen. Bakker had als relatieve buitenstaander geen last van opsluitende hardheid. Bovendien bezat Bakker de positie, de creativiteit en de kennis om zich zo in te leven in beide denkramen dat ze zich ook de aan de weerbarstige hardheid kon onttrekken. Mede hierdoor kon het planproces uiteindelijk weer verder en verloor Hoog Catharijne haar hardheid.

In hoofdstuk 4 staan de pogingen tot herontwerp van de A2-stadstraverse door Maastricht centraal. Al sinds de jaren ' 70 proberen de gemeente Maastricht en Rijkswaterstaat om het ontwerp van de weg aan te passen aan het toegenomen autoverkeer. Volgens de gemeente is het noodzakelijk om de stad bereikbaar te houden en om de geluid- en stankoverlast voor de omwonenden te verminderen. Het voorstel om een tunnel aan te leggen speelt al enkele decennia een rol in de discussies, maar er heeft nog steeds geen reconstructie van de weg plaatsgevonden. In dit hoofdstuk gebruik ik de metafoor van 'verknooptheid' om de toenemende hardheid van de snelweg door Maastricht te verklaren. Doordat de snelweg in de loop van de tijd in toenemende mate geïntegreerd raakte in het stedelijk verkeerssysteem en in de stedenbouwkundige structuur van de stad werd het steeds moeilijker het ontwerp van de weg aan te passen. Ook gebruikerspraktijken droegen bij aan de toegenomen hardheid van de weg. In de jaren ' 80 en ' 90 blijkt ook de paradoxale rol van nieuwe wettelijke regelingen, zoals de Wet Geluidhinder, die enerzijds aanpassingen aan het bestaande wegontwerp noodzakelijk maken, maar anderzijds veel oplossingen uitsluiten. De wijze waarop deze verknooptheid veranderingen in het ontwerp van de 
weg bemoeilijkte, wordt ook duidelijk in mijn analyse van de manier waarop het idee van een tunnel als oplossing voor de problemen rond de snelweg verbonden raakte met het beleid van de gemeente en de verwachtingen en idealen van burgers. Hoewel de tunnel geen realiteit werd, kreeg dit idee een grote hardheid. Verder besteed ik aandacht aan twee verschillende strategieën om on te gaan met de verknooptheid van de snelweg. De eerste strategie was een open plan proces op basis van de Infralab methode waarbij de verknooptheid van de snelweg tijdelijk opzettelijk genegeerd werd. Hierdoor ontstonden nieuwe, creatieve ideeën voor oplossingen. De tweede strategie was het ontwerpatelier, waarbij de verknooptheid van de snelweg met de stedelijke omgeving juist als uitgangspunt genomen werd en men alternatieven zocht op basis van een afweging van de hardheid van verschillende elementen warmee de snelweg verbonden was geraakt.

In hoofdstuk 5 analyseer ik de ruimtelijke vernieuwing van de Bijlmermeer. De Bijlmermeer is een van de meest bekritiseerde woonwijken in Nederland. Behalve kritiek op de grootschalige architectuur met grote flatgebouwen werd de Bijlmer een vluchthaven voor etnische minderheden, vluchtelingen en asielzoekers. Bovendien werd de Bijlmer in toenemende mate geassocieerd met criminaliteit en drugs. Toen er steeds meer flats kwamen leeg te staan en de woningbouwcorporatie te maken kreeg met grote financiële verliezen, werd besloten tot een radicale ruimtelijke vernieuwing van de wijk. Begin jaren ' 90 werden de eerste flatgebouwen daadwerkelijk gesloopt. In de analyse van het vernieuwingsproces leg ik de nadruk op de rol van hardnekkige tradities in de constitutie van hardheid van stedelijke structuren. In deze casus laat ik zien hoe specifieke kenmerken van de CIAM-traditie en de utopische traditie in de stedenbouw, de discussies in het ruimtelijke vernieuwingsproces in de Amsterdamse Bijlmermeer bleven domineren. Telkens werden specifieke ontwerpkenmerken van de CIAM-traditie gemobiliseerd door verschillende actoren met als doel om elementen van de Bijlmermeer te behouden of te veranderen. Ook hechtten verschillende actoren belang aan bepaalde aspecten van de utopische traditie, zoals het maakbaarheidsdenken, het streven naar gemeenschapszin en de consistentie in het ontwerp - zaken die bij het oorspronkelijke ontwerp van de Bijlmer ook al belangrijk waren. Het willen vasthouden aan de consistentie in het Bijlmerontwerp was een van de redenen waardoor het moeilijk bleek om de Bijlmer te veranderen. Een groep Bijlmerbewoners verenigd in het Bijlmermuseum, pleitte sterk voor het vasthouden aan de oorspronkelijke ontwerpidealen bij het herontwerpen van de Bijlmer. Voor deze groep waren bepaalde CIAM-kenmerken van de wijk juist aantrekkelijk. Deze groep slaagde er uiteindelijk in om een deel van de Bijlmer hard te houden: in het Bijlmermuseum.

In hoofdstuk 6 concludeer ik dat, om tot een goed en verfijnd begrip van het fenomeen 'hardheid van techniek' in de stedelijke context te komen, het nodig is om de verschillende concepten van 'obduracy' die in dit proefschrift de revue passeerden in de analyse te integreren. De constructivistische concepten die ik in dit proefschrift behandeld heb sluiten elkaar niet uit, maar moeten juist als complementair worden beschouwd. Samenvattend kunnen de concepten als volgt met elkaar verbonden worden: Sociotechnische stedelijke structuren maken altijd deel uit van een groter netwerk van regels, plannen, beleid, instituten en normen - een netwerk waarin ze geleidelijk aan geintegreerd en verknoopt raken. Deze integratie leidt tot een grotere 
hardheid. Dit proces wordt vergezeld van het opbouwen van technische ramen door verschillende sociale groepen. Deze denkramen kunnen zowel betrekking hebben op bestaande stedelijke artefacten als op plannen voor herinrichting. De betekenissen en waarden die toegekend worden aan stedelijke sociotechnische structuren maken deel uit van deze denkramen en zullen een belangrijke rol spelen in het onderhandelingsproces tussen groepen actoren over de hardheid van sociotechnische elementen. In tegenstelling tot technische ramen overstijgen hardnekkige tradities lokale contexten en hebben ze een diepgewortelde culturele invloed. Tradities, gedeelde waarden en collectieve normen beïnvloeden unbuilding processen in de zin dat geen van de actoren hier makkelijk alan ontkomt. Doordat actoren tradities blijven mobiliseren keren bepaalde keuzes telkens terug in het herontwerpproces. Bij de analyse van obduracy in sociotechnische veranderingsprocessen moet in specifieke case studies onderzocht worden welke van de drie concepten van obduracy het meest bruikbaar zijn. 


\section{Curriculum Vitae}

Anique Hommels was born on the $3^{\text {it }}$ of December 1972 in Bunde. After finishing sccondary education (Gymnasium A) at the Jacobuscollege in Enschede in 1991, she studied Arts and Sciences at the University of Maastricht. During the final stages of her specialization in "Theory and History of the Technological Culture", she spent a few months following courses at the Science Studies Unit of the University of Edinburgh, UK. In 1995 she became a student-assistant at the Department of Philosophy, University of Maastricht. For her MA thesis she received an award of Royal Institute of Engineers of the Netherlands. After being awarded the degree of MA she subsequently became a PhD student at the Department of Technology and Society Studies of the University of Maastricht (1996). She followed the intensive $\mathrm{PhD}$ training of the Netherlands Graduate School of Science, Technology and Modern Culture (WTMC). During her PhD research she also participated in an international research project commissioned by the European Commission (1998). In 2000 she accepted a part-time position as a lecturer at the Faculty of Arts and Culture at the University of Maastricht. Besides teaching, she became appointed as a researcher at the International Institute of Infonomics (2001) - a research institute that has recently been established by the University of Maastricht. Her present research concentrates on the mutual shaping of ICT and society with a focus on the domain of mobility and transportation. 